

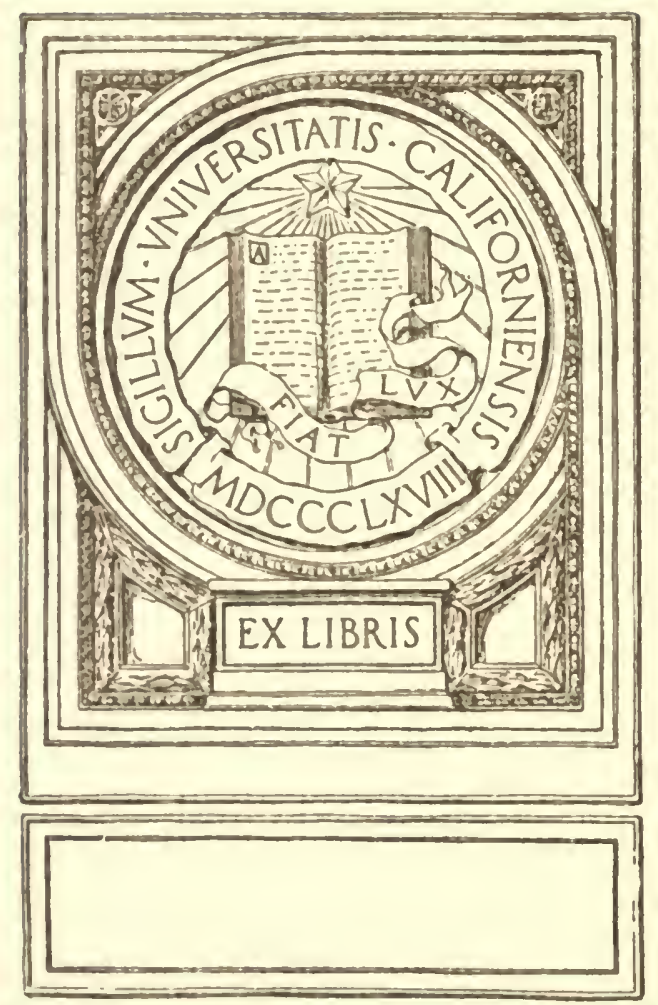







$\because$ 


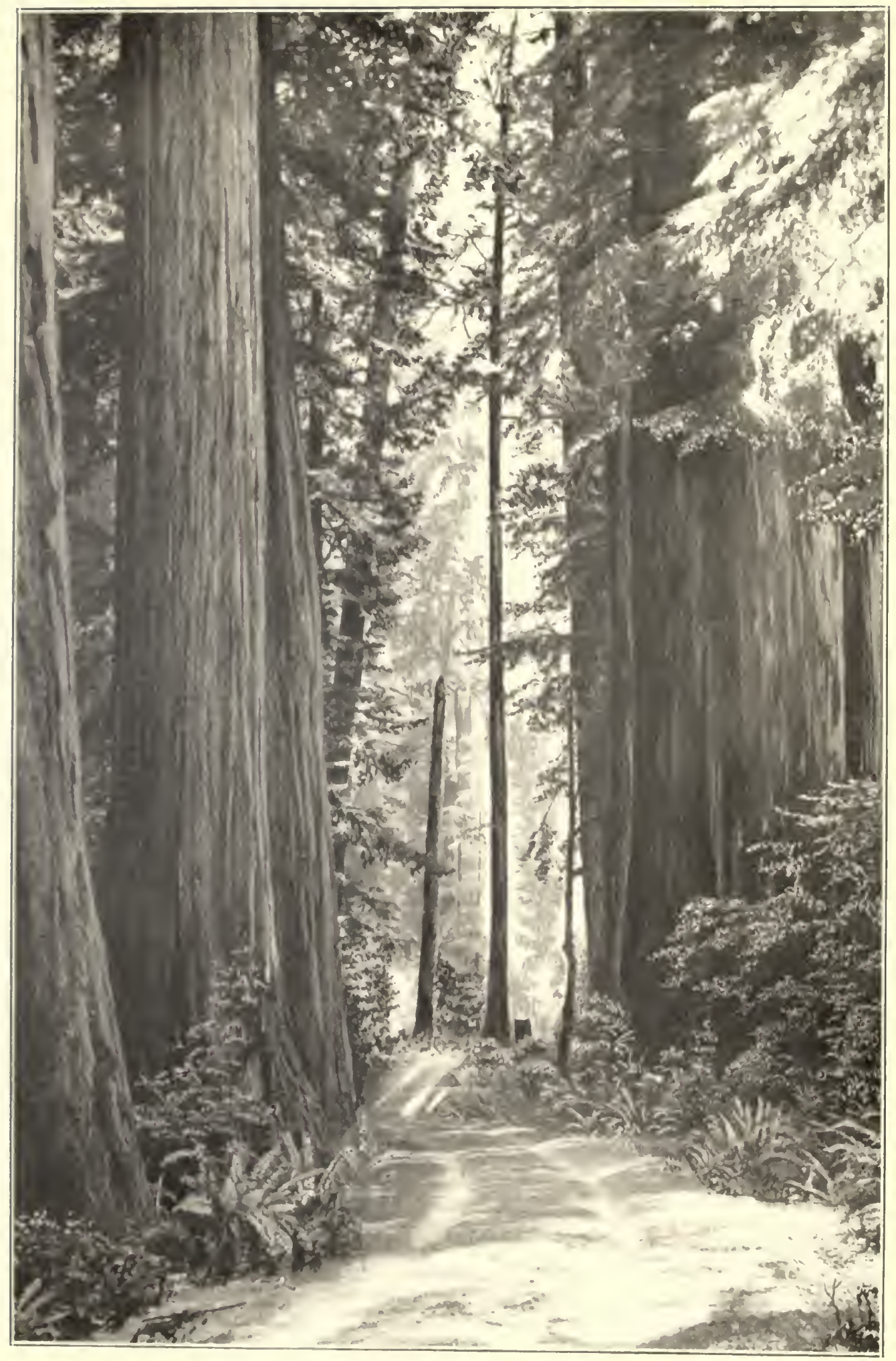

COAST REDWOOD. Humboldt County.

mparting an elfect of archuectural of green far above and illumines the aisles between the giant pillars. of worship of tes people." - Henry Fairfield Osborn. 


\title{
SHADE AND ORNAMENTAL TREES OF CALIFORNIA
}

\author{
BY \\ MERRITT B. PRATT \\ State Forester
}


TO THE MEMORY OF

\section{G. MORRIS HOMANS}

STATE FORESTER FROM MARCH, 1910, TO NOVE.MBER, 1921 A PIONEER OF FORESTRY IN CALIFORNIA

466418 


\section{CALIFORNIA STATE BOARD OF FORESTRY}

Dr. (ico. C. Pardee, Chaiman

R. E. Danaher

Col. Ed. Fletcher

Merritt B. Pratt

Solon H. II illiams ()akland

Camino San Diego Sacramento

Yreka

Office of State Forester

Merritt B. Pratt

State Forester

Solon H. II illiams

Deputs

IVm. B. Rider

Assistant

\section{State Forest Nursery at Davis}

Alhert Aldinger

Nurseryman in Charge 


\section{CONTENTS}

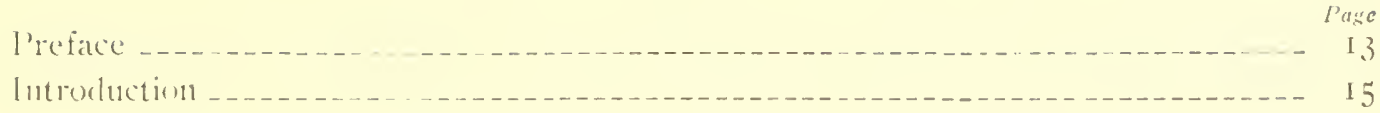

\section{PART I}

\section{CONIFERS}

Iratuarialo

California Nutmeg-_.....

Cerlars. Cypresses and Sequoias

celrus

'T'huya _._.

Thutyopsis

(uipresisus _........

Chamaecyparis

Libocedrus

T'axorlium

$I^{\prime} a g e$
17
19
19
20
22
23
23
25
26
27

Page

- Sequloia

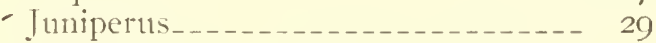

Cryptomeria ..................... 30

Douglas Fir _................... 31

Firs _...... 32

Ginkgo_.._. 33

l'ines _..._..._._._. 34

Spruces _....._. 39

Yews _.......................... 4 I

BROAD-LEAF TREES

tcacias ancl False Acacias

Acacias

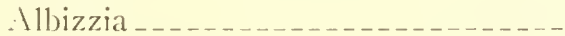

Blach [ocust

I Ioney I ocust

trlies

lirches

liladker-nut_...

liottle-brushes

lirisbane Pox - - -

California laurel

Camplor

Cape Chestuut

Carols

Casuarina

Catalina I romweorl

Catalpá

Cherries and l'lums.

Chestnut

Copper lieech

Cural Tree

Crape Myrtle

Christmas Perry

\begin{tabular}{|c|c|}
\hline$g e$ & \\
\hline & 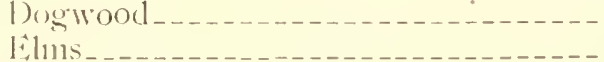 \\
\hline & limpress Tree \\
\hline & Eutcalviptus - . \\
\hline & Eugenia______. \\
\hline & den Chain \\
\hline & hor'1 \\
\hline & ckorics._- \\
\hline & llies_- \\
\hline & IHorse Chestnut \\
\hline & osporum \\
\hline & a $-\ldots-\ldots-1-\ldots-1$ \\
\hline & lem 'Thorn_..._. \\
\hline & 1 1.aurel _.......... \\
\hline & 1 l.inden \\
\hline & - - n- \\
\hline & lias _...... \\
\hline & Maples-n.....- \\
\hline & Maytes -. \\
\hline & Mulluerry $\ldots$ \\
\hline & \\
\hline & \\
\hline
\end{tabular}




\section{BROAD-LEAF TREES - Continued}

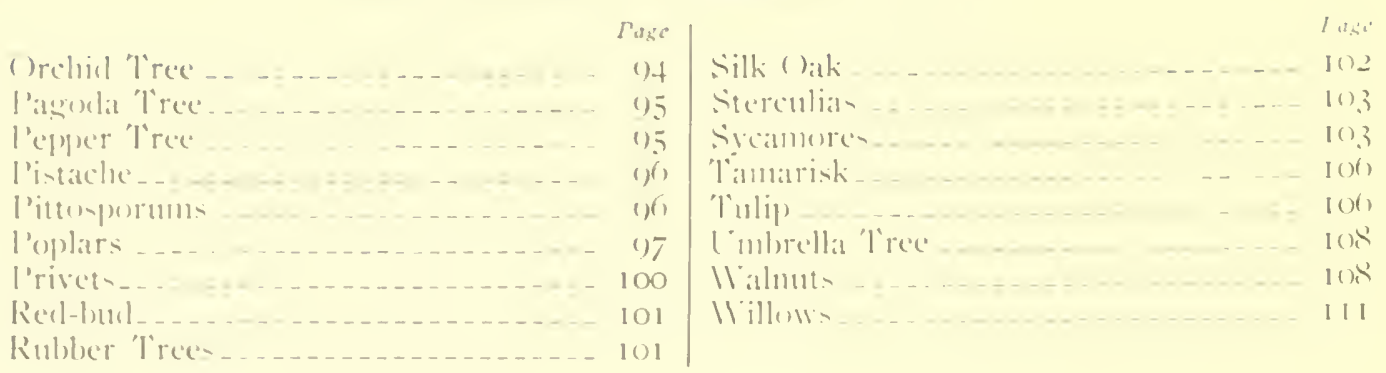

\section{PALMS}

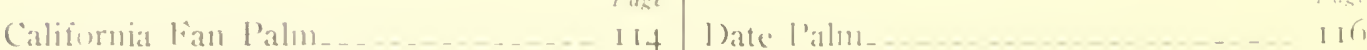

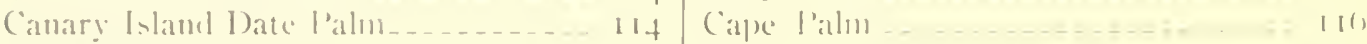

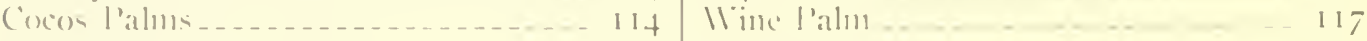

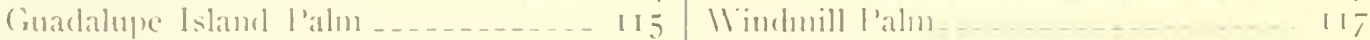

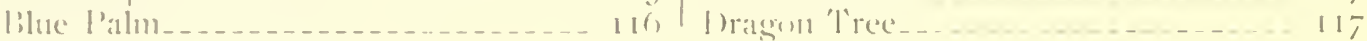

\section{PART II}

Tree list for bifferent liegions of (alifornia-

Region I-Siacramente and sian Joaquin lalleys _. . 120

kegion II_Ciastal_........... I I I $l^{\prime}\left(i_{i}^{\prime} e^{\prime}\right.$

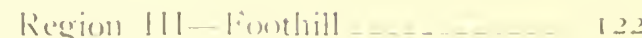
Revion II-Sinullern Californtat_. 12.3 . Ihali Resistant 'lreén_... _..... 124 lieferences _. _ _ _ 125 Index_... $\ldots \ldots \ldots \ldots \ldots$ 


\section{ILLUSTRATIONS}

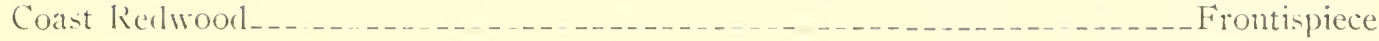

\begin{tabular}{|c|c|c|}
\hline late & $\begin{array}{l}\text { Betaten } \\
\text { P'ages }\end{array}$ & $\begin{array}{c}\text { Between } \\
\text { Pages }\end{array}$ \\
\hline & liackwoon. & 4+. Encalypts and l'alms \\
\hline & $-18-19$ & +5. Red Gium \\
\hline & $-\ldots-2 \mathrm{O}-2 \mathrm{I}$ & 46. I.emon-scented Grmm. \\
\hline & $--\ldots 2 \mathrm{O}-2 \mathrm{I}$ & on-scented Cim 'Trumk _.. $62-63$ \\
\hline & untinople Acacial _..... 22-23 & 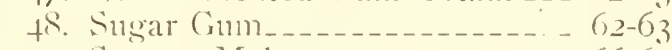 \\
\hline 6. & ntinople Acacia lilossonns 22-23 & 4). Sin \\
\hline & Y' P'uzzle _......... 24-25 & Ginl11_- \\
\hline & $\ldots \ldots-24-25$ & 51. 13 \\
\hline 9 . & $a c^{2}-\ldots-\ldots$ & $\therefore$ Tre \\
\hline 10. & 24 & is Fir \\
\hline 11. & ---- & ------ \\
\hline I 2. & 11 (herry_-...-2t & - n \\
\hline 13 & $\ldots \ldots-\ldots$ & 56. \\
\hline 14. & S1 & $57 \cdot 1 \cdot 1$ \\
\hline 15. & 111 & $5^{8} \cdot(\mathrm{C}$ \\
\hline 16. & $1---$ & 59. English 11 as \\
\hline & $\begin{array}{l}\text { rian liottle Tree } \\
\text { ane liox }\end{array}$ & $\begin{array}{l}\text { (ro. I'anl's Domble-Howering I Iaw- } \\
\text { thom }\end{array}$ \\
\hline [(). & re & ark llickory _...... \\
\hline 20. &.- & ---- \\
\hline 21. & ........ & orwim_-- \\
\hline 22. & (........... & 4. \\
\hline 2.3. & $1 \ldots$ & Tree - \\
\hline 24. & $-\cdots$ & - \\
\hline 25 & $\therefore-$ & 7. \\
\hline 2() & 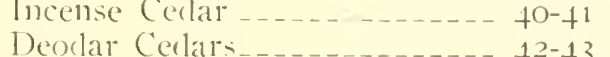 & 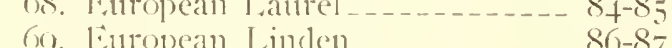 \\
\hline 27 & -- & $1-$ \\
\hline 2). & $\begin{array}{l}-t \\
--t\end{array}$ & 1. 1.ocust 1 - \\
\hline 30. & $\ldots$ & crings 1.ocnst _. \\
\hline 31 & & 7.3. 1 \\
\hline 32. & t & $7+1$ \\
\hline 3.3 & 5 & ()111-- \\
\hline 34 & sit & .lla1 \\
\hline$\Rightarrow$ & $s$ & caf Maple -. \\
\hline $3^{6}$. & $--52-5.3$ & - \\
\hline & $2 \ldots+54-5$. & $\ldots \ldots+\ldots-6$ \\
\hline 35 & $-\ldots-54-55$ & Mlulberry. \\
\hline 39 & $6-5$ & Si. \\
\hline 40. & -57 & 82. \\
\hline+1 . & $111 \ldots$ & ()- - - - \\
\hline t. & mperdow lin & ak_- \\
\hline & & \\
\hline
\end{tabular}




\section{ILLUSTRATIONS-Continued}

\begin{tabular}{|c|c|c|c|}
\hline Plate & Ratian & $1 \%$ istic & l'itir \\
\hline sit). (Neamirler. & $1(1)-11) 3$ & 112 ling 'lres. & $126-127$ \\
\hline š. ()rchinl 'Tree $=$ & $104 \cdot 115$ & 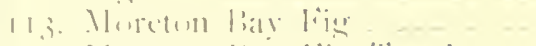 & $123-130$ \\
\hline 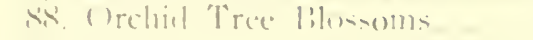 & 10.4115 & 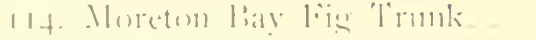 & $12 x^{\prime}-121$ \\
\hline si). (l)lives . . . . . . . & $10+105$ & I I. Silk ( )ilk ............ & $128-129$ \\
\hline (口). ('alifornia l'epprer 'l'ree & $104-105$ & I11. Silk ( )ilk lilosinms & 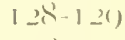 \\
\hline 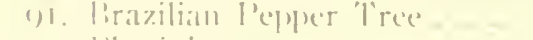 & $1(1)(1-1)-$ & 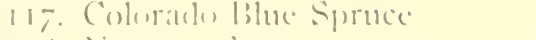 & 12013 \\
\hline 12. [ |hotinial _......... & $I(1)()-I())$ & lil! Syruce - & $12(3-1-4)$ \\
\hline "). Italian sitne l'ille - & $10 x-1(x)$ & I11). 'l' & $12 k-121$ \\
\hline 1) t. l'ines 01 . Mnutere! - & $108-1(x)$ & 120. Tulip Tree - & $12 k-121)$ \\
\hline 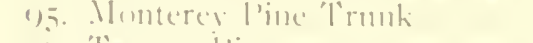 & $11(0-111$ & ij) 'l'ree lilasentm & $12(1)$ \\
\hline (x). 'Torre! l'ille ... & $|1(1)-1| \mid$ & mell:1 $\operatorname{Trce}$ & $128-121)$ \\
\hline 1), Pirrey !'ine (imes & $11.1-115$ & 123. ('alifurnial liack 11 alnut & $128-121)$ \\
\hline 's'. Cinlter l'inc & $11+115$ & formia lilack 11 illnut - & $12 k 131$ \\
\hline (x). Mlepu l'ine & $1111-11 \%$ & pine 11 illows & $8-1-3(1)$ \\
\hline 100. Cilnary I-land l'ine & $110-117$ & 126. Iri-h lelli & $2 \hat{2}-123$ \\
\hline (1) p)erime & 1はー-111) & $12, \%$ & 2(1) \\
\hline 102. Tictorian Piox ... & (1゚-111) & I 25. 1)ragon '1ree & $13 x-15$ \\
\hline I03. I'mrple-leatreal l'lum - & 120121 & 121). lilne |'allur & $1-3-153$ \\
\hline (lon l'lane -... & $120-121$ & sland l'alm & $-121)$ \\
\hline 105. Califurmat Sicanure & $120-121$ & 1.31. (ape l'alin - & $52-151$ \\
\hline lox). Carulina l'oplar - & $120-121$ & $\therefore$ ['alms - & $12 k-121)$ \\
\hline 107. lembarmy loplars & $122-12,3$ & (' ['il]111-...... & $(-1)$ \\
\hline [mon Poplat - & $122-12.3$ & Galupe l'alm & $128-12()$ \\
\hline 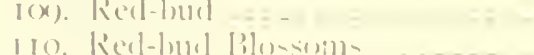 & $124-125$ & 1.35 .11 & $8-123$ \\
\hline 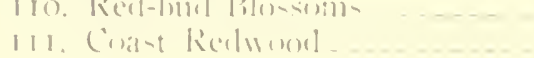 & $124-125$ & 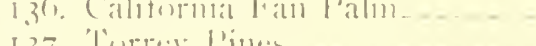 & -129 \\
\hline $111 . \mathrm{C}$ & 12()$-127$ & 1.37. & $(8-129$ \\
\hline
\end{tabular}




\section{SALUTE TO THE TREES}

\section{HENRY VAN DYKE}

Many a tree is found in the wood

And every tree for its use is good;

Some for the strength of the crnarled rout,

Some for the sweetness of flower or fruit;

Some for shelter against the storm,

And some to keep the hearthstone warm;

Some for the roof and some for the beam,

And some for a boat to breast the stream-

In the wealth of the wood since the world began

The trees have offered their gifts to man.

But the glory of trees is more than their gifts:

'Tis a beautiful wonder of life that lifts,

From a wrinkled seed in an earth-bound clod.

A column, an arch in the temple of God,

A pillar of power, a dome of delight,

A shrine of song, and a joy of sight!

Their roots are the nurses of rivers in birth;

Their leaves are alive with the breath of the earth;

They shelter the dwellings of man; and they bend

O'er his grave with the look of a loving friend.

1 have camped in the whispering forest of pines,

I have slept in the shadow of olives and vines;

In the knees of an oak, at the foot of a palm

I have found good rest and slumber's balm.

And now, when the morning gilds the boughs

() f the vaulted elm at the door of my house,

lopen the window and make salute:

"God bless thy branches and feed thy root!

Thou hast lived before, live after me,

Thou ancient, friendly, faithful tree.' 



\section{PREFACE}

The economic value of good roads has far surpassed the claims of its early protagonists twenty years since. The value of road improvement by means of well-planted trees and shrubs, pleasing bridges, water outlets, stone records and designs is just as great as the economic value-a doctrine which has been steadily growing and is now gaining full assent.

Out-of-doors recreation is accepted as a necessary part of the life of a Californian - as a vital element in bodily well-being, mental diversion and imaginative stimulus. Roads decorated with trees and shrubs, here revealing continuous charms, on occasion curtaining an ugly spot, are in keeping with the glory of the far-flung landscapes of California; barren or unsightly roadways would be paradoxical in a land of beauty.

II hile highways, to be sure, are of extreme importance to motorists, an importance which can scarcely be overestimated, highways are not merely for motorists. Travelers from the East constantly comment upon a California phenomenon never seen in Eastern cities - the long strings of men and girls pouring out of our cities and towns on holidays, clad in hiking costumes and filing along the roadways-for the roads lead to the trails and the trails to the hills.

The work of our State Department of Forestry in planting and decorating the highways assumes, therefore, more than a special or group interest. While such improvements increase the pleasure and contentment of the traveler and add large economic values to the regions traversed by the roads, the work serves an additional purpose in giving expression to the spirit of our people, their feeling for the out-of-doors-for the hills, valleys and mountain ranges of this state. For these roads will not merely carry the traffic load of trade, binding city to city, but ably planned and adorned they will be silvan threads worthy to join the wonderlands of California each to each and these in turn with the centers of population. In this manner such work will give a visible sign of the mental attitude and spirit of the Californians.

Willis Linn Jepson.

University of California, June 18,1921 . 



\section{INTRODUCTION}

The purpose of this publication is to stimulate more widespread interest in the planting of trees in California. There are thousands of miles of highway in the state that should be beautified and shaded with suitable trees. Many streets in our towns and cities as well as school and home grounds need trees both for their beauty and shade. Californians have a wide range of trees from which to choose, species coming from all parts of the world. No attempt has been made to describe in the following pages all the shade and ornamental trees grown in the state. The species described, however, are of sufficient variety to answer most of the inquiries constantly being received regarding the characteristics of trees which it is desired to plant.

Trees are something more than green things or mere firewood. They have human aspects which the Greeks well knew when they made "the forest rivers garrulous with babble of gods." From the far-off days when the prophetess of ancient Israel "dwelt under the palm tree of Deborah," and the people came up to her for judgment, trees have played an important part in the history of nations. Their significance is thus expressed by Reginald Wright Kauffman:

"N lankind has always regarded the tree as friendly and often as divine. There was the mystic oak of the Druids; the sacred Bo-tree of Buddah; the ash Yggdrasil of Aorse mythology, whose roots were in the underworld, hut whose arms reached to the Asa-gods above the skies. How large a part the tree has played in our own Holy Writ, from the Tree of Knowledge of Good and Evil in Genesis to that Tree upon which the Divine Sacrifice was consummated, I need not, surely, remind you."

In our own history we have trees that have long been cherished as living memorials of great cleets, such as the Charter Oak, and the Washington Elm.

Our forefathers did not neglect the improvement of their village and home grounds, but planted trees, the stateliness of which now bears witness to their foresight. New England is famous for its elm-bowered villages, and New York and Ohio for their maple-shaded towns. 


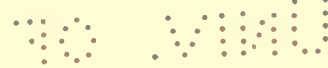

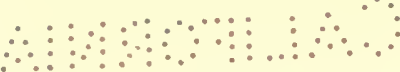

The early colonial traditions that prompted the planting of trees in the berstem states were largely lest in California during the "days of "to." although many of our mining towns have tress that were planted by the gold seckers at that time The unseteled comditions that prevailed, howerer, and the undereloped conditions "ith which the heme-huilder had to contend, make tree planting a secondary consideration.

\ow that the pionecring lass are wer and settled conditions prevail, more and more interest is heing taken in making commonnity and rural life more attractive. There can he no more pleasant surroundings than are provided hy trees. Vi man who has planted a tree and watched it grow can fail to appreciate how responsive and grateful it is to human help. A seedling placed in unused ground pays hack a thousand fold in beauty. and in its response (o) care. It talks of man's works to posterity as is so well stated by L_ü! Larcon

"He who plants a tree

He plants lore.

Tents of coolness spreading out abore

Il avfarers he may not live to see. 


\section{CONIFERS}

Conifers with the exception of larch, bald cypress and ginkgo retain their leaves throughout the year and are commonly known as evergreens. It is their evergreen habit and foliage of gray to dark green shades that gives them their chief ornamental value. During the early period of their lives they are conical in form with branches extending to the bases of the trees. In later life they develop spreading crowns which surmount straight, cylindrical trunks, and in old age they become rugged and picturesque in appearance.

On account of their shape and mode of growth, conifers are not as good for streets as broad-leaved trees. Their best use is as specimens or groups to accentuate an elevation, or define a boundary. When planted in masses they serve to bring out the sky line more effectively than do broad-leaved trees. They fit into country places when carefully selected and placed. On account of their somber shades they should not be placed near houses, but rather against a lively background such as would be provided by bright-foliaged trees.

The large growing conifers should be planted where they can be seen at some little distance and not be crowded in order to show them to their best advantage in their entire form and outline. The smaller conifers can be used to advantage to accentuate mass plantings and in formal gardens.

The value of conifers for decorative effect has been only recently recognized in this country. Quick growing, short-lived material has been used with little thought of the future. People are now waking up to the fact that nothing else can give the solidity, strength and virility so noticeable in European gardens where the use of conifers has predominated for centuries.

\section{ARAUCARIAS}

The Araucarias are magnificent trees with whorled branches and stiff pointed leaves, which grow naturally in Brazil, Chile, Polynesia and Australia. The name of the genus is derived from Arauco, the name of the district in southern Chile where the tree was first discovered. Altogether there are about a dozen species. Several species are widely planted in California and do well 
over a wide range of soil and climatic conditions. The araucarias are grown on a large scale in nurseries in pots since the young trees are favorite house decorations because of their novel appearance and ability to withstand hard usage

\section{NORFOLK ISLAND PINE}

The Xorfolk Island pine (Araucaria excelsa), also known as "Star Pinc," is a native of Norfolk Island and New Caledonia, and was discovered by Captain Cook on one of his royages. The tree reaches a height of 200 feet and a diameter of nine to ten feet in its native habitat. Its branches cre arranged in regular whorls with intervals of bare stem separating each whorl. The hranches are horizontal and densely covered with light-green, awl-shaped leares. This tree has a distinctiveness of character and solemnity of outline which sets it apart from most trees.

\section{MONKEY PUZZLE}

The name of this peculiar tree, "Monkey Puzzle" (Araucaria imbricata). was given it hecause of its twisted branches which it would puzzle a monkey t) climb. It is a native of Chile where it forms forests on the Cordilleras The leaves, which are short, broad and triangular, overlap like shingles and closely surround the trunk and branches. The cones, which are about eight inches broad and seven inches long, do not appear until the tree is quite old. This tree thrives well in a heavy, loam soil, but should not be planted in an exposed position since the branches are heavy and brittle and if broken by the wind soon cause the tree to lose its symmetry of form. It is extensively grown in the open in England and I reland and is probably the hardiest of the araucarias grown in this state.

\section{BUNYA-BUNYA}

The Bunya-bunya (Araucaria bidwillii) is a native of Queensland where it reaches a height of $150 \mathrm{feet}$. The cones are as large as a man's head and bear seed which are used for food by the natives. The leaves are flat, sharp and of a glossy-green color. The lower branches on an old tree strike the ground about ten feet from the trunk and then rise to a height of about three feet. For this reason this tree as well as the other species of araucaria should be planted with plenty of room for development. 


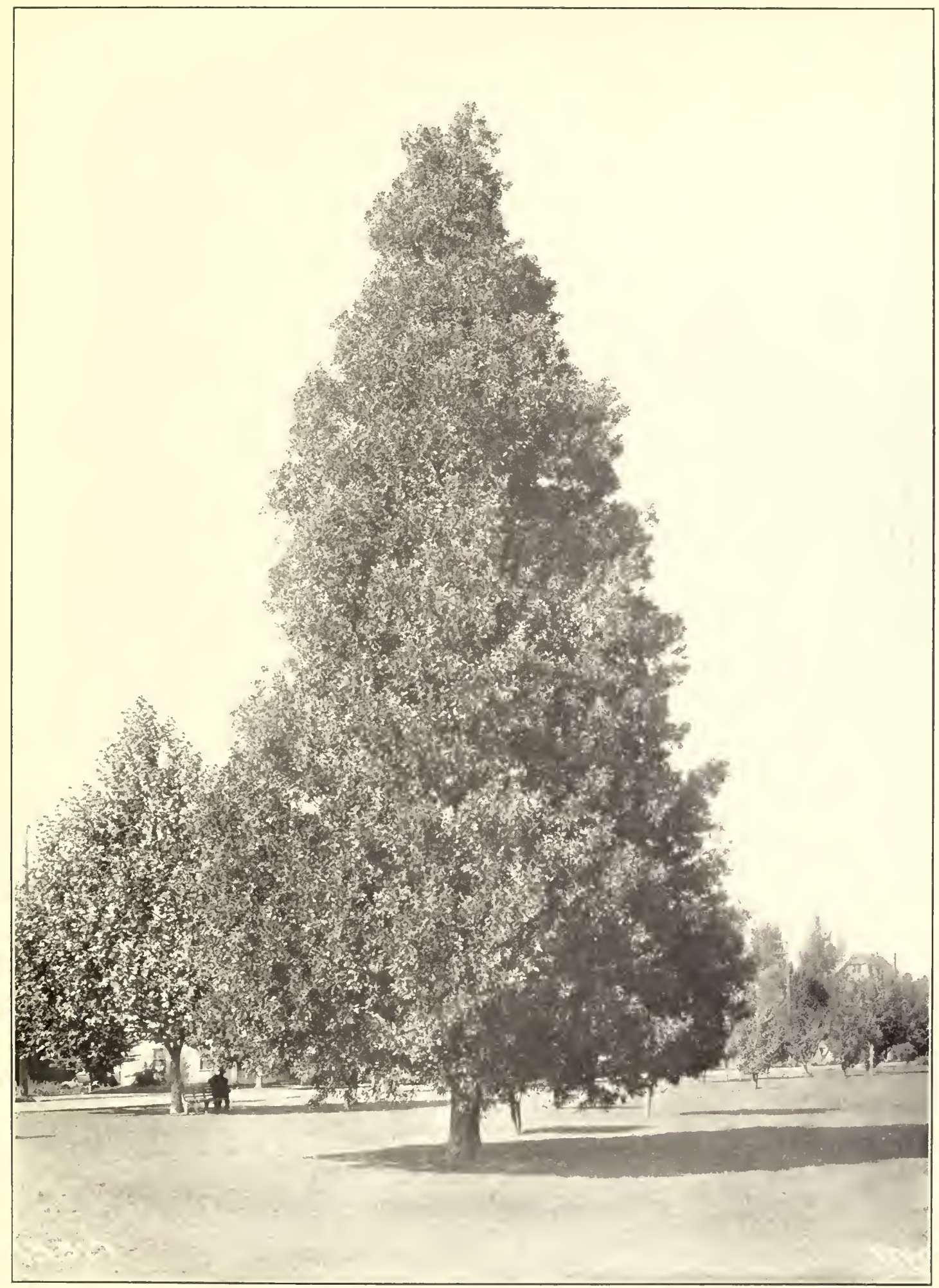

Plate 1. BLACKWOOD ACACIA. Sacramento.

A symmetrical tree with light yellow flowers. The blossom of the wattle, one of the acacias, is the national flower of Australia. 


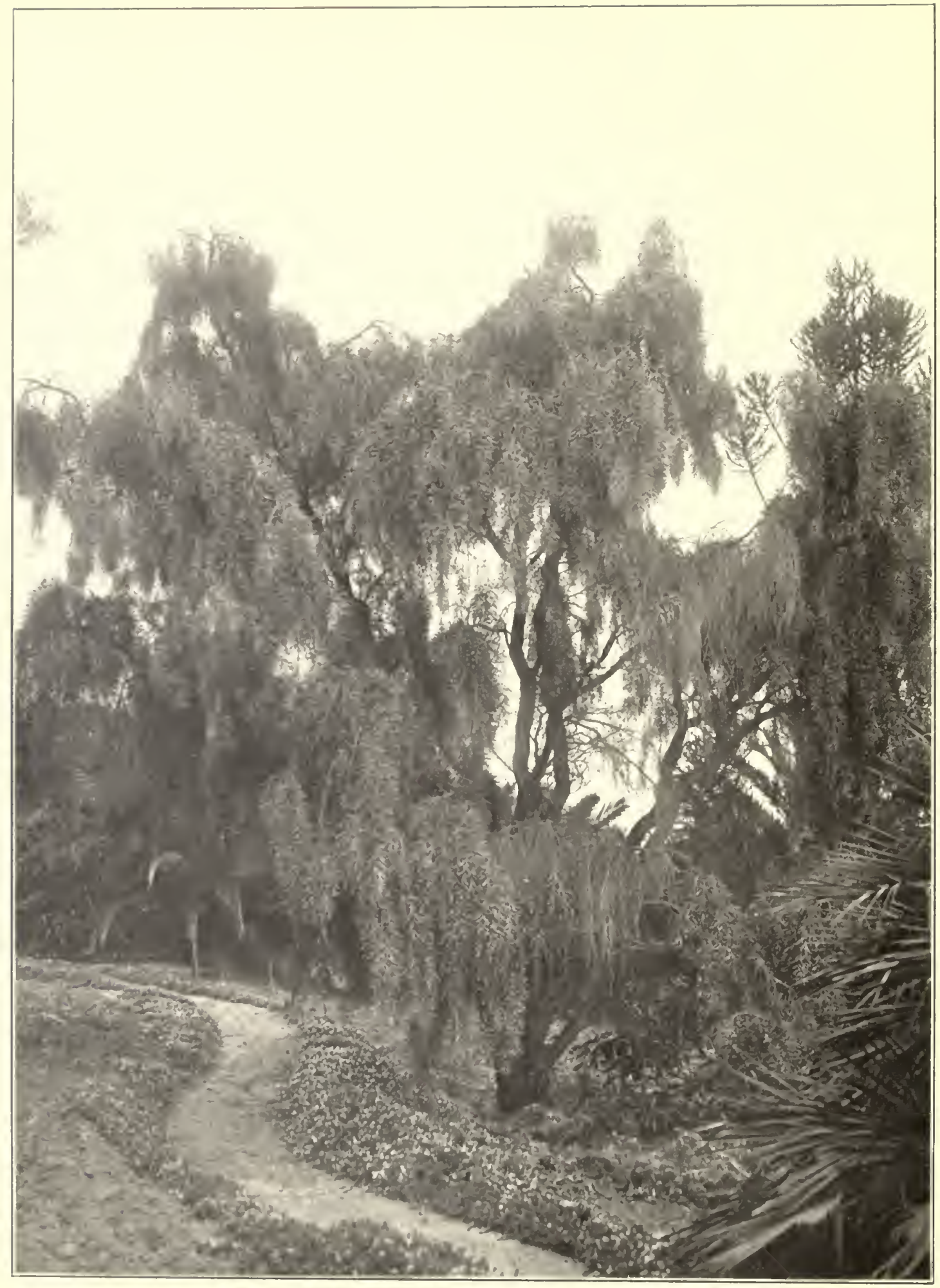

Plate 2. WEEPING MYALL. Santa Barbara. 


\section{CALIFORNIA NUTMEG}

California nutmeg (Torreya californica), so called because of the resemblance of its fruit to nutmegs, is one of the most singular, as well as one of the most handsome of California trees. It is found scattered along borders of streams or in creek bottoms in the Coast Range and Sierra Nevadas, rarely exceeding twenty feet in height. Some trees have been found in the Santa Cruz Mountains, however, that are eighty-five feet high and two feet in diameter.

This tree was discovered in about 1853 and specimens were sent to Dr. John Torrey of Columbia College, who worked out its botanical characteristics. It resembles the yew in its general appearance, but the leaves are rigid with sharp points. They are of a shining green color, and give the impression of having been glazed or varnished. The branches are spreading and are usually whorled. California nutmegs are little known in cultivation. They are mainly grown in botanic gardens because of their interesting characteristics of leaf and fruit.

\section{CEDARS, CYPRESSES AND SEQUOIAS}

The cedars, cypresses and sequoias embrace several genera of trees that are more or less botanically allied, and have much in common in form and behavior. They are characterized by an upright habit of branching and a full supply of foliage which makes them effective in formal planting and as specimen trees. They are usually adaptive to soil conditions and are easily handled.

The term "Cedar," which is derived from a word meaning "life from the dead," is generally applied to a wide range of species belonging to different genera. This is due perhaps to the association of the word with woods posessing exceptional durability. The Egyptians used cedar oil for preserving mummies, and the wood for mummy cases. Carred figures of cedar wood several thousands of years old can be seen in our museums of today. In the United States, southern red cedar, incense cedar, Port Orford cedar, western red cedar and cypress are genera which have species commonly known as "cedar."

The durability of cedar was well known to Oliver Wendell Holmes who says:

"*** the fair cedar, fallen before the breeze,

Lies self-embalmed amidst the mouldering trees." 


\section{CEDRUS}

The true celars belong to the genus (edrus, which grows naturall! in Ifrica. Asia . M linor and India, and embraces only three species. There are no true cedars native to this country, in spite of the fact that we give the name to several of our trees. Like our so-called celars, the true celars are valuable timher trees in their native habitats. They also have high omamental value and are extensively planted on lawns and avenues in this state. They are long-lived trees of commanding appearance. In teep, well-drained, gravelly loam thes make rapid growth reaching an average height of from eighty to 100 feet. The cones are horne erect and are very striking.

\section{Cedar of Lebanon}

Cedar of Lethanon (Cedrus libani) is native only to certain restricted areas in Asia Minor and North Africa. It was one of the principal woods used in the construction of King Solomon's temple, and frequent references are made to it in the Bible as a symbol of power, prosperity and longerity. The following passage is found in the hook of Ezekiel:

"Behold the Assyrian was a celar in Lehanon with fair branches. and with a shadowing shroud, and of an high stature; and his top was among the thick boughs. $* * *$ Therefore his height was exalted ahove all the trees of the field, and his boughs were multiplied, and his branches hecame long because of the multitude of waters."

Mount Lebanon, on which this ceclar grows at an elevation of 6,000 feet, is covered with snow during the greater part of the year, but on August fifth, the eve of the lieast of the Transfiguration, the people in the surrounding villages visit the mountain and there celebrate the "Feast of Ceclars." The too cedars that are the remnant of the forest that furnished the timber for the temple at Jerusalem are now enclosed by a high stone wall and protected hy the Nlaronite monks. They are upwards of 2000 years old. The best preserved trees are about 100 feet high and one has a circumference of fortyseven feet.

The most striking characteristics of the cedar of Lebanon are its hroal spreading hahit and broad, flat head of bright, bluish-green foliage. It seldom reaches over eighty feet in height, but its horizontal branches, which spread 


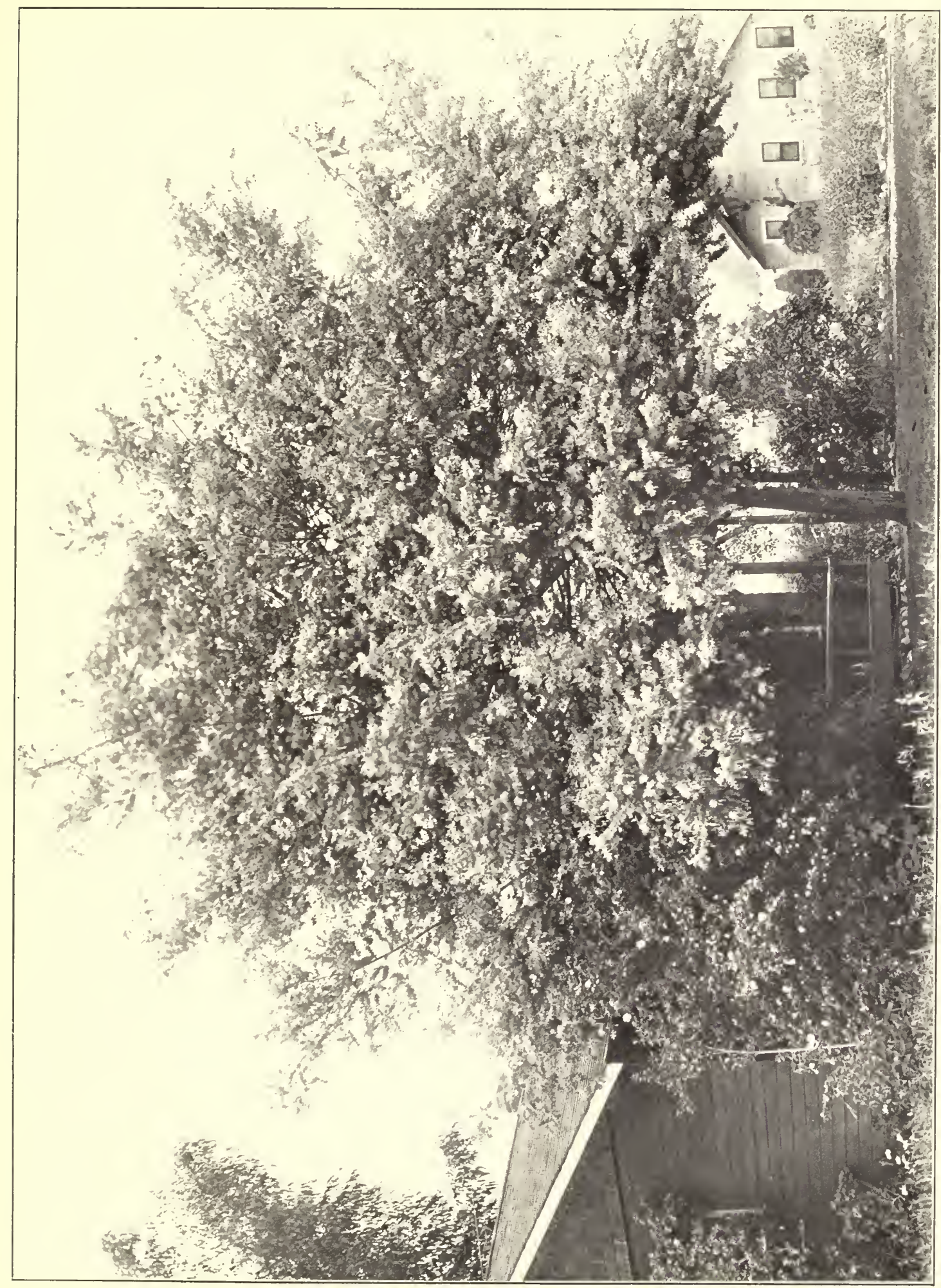




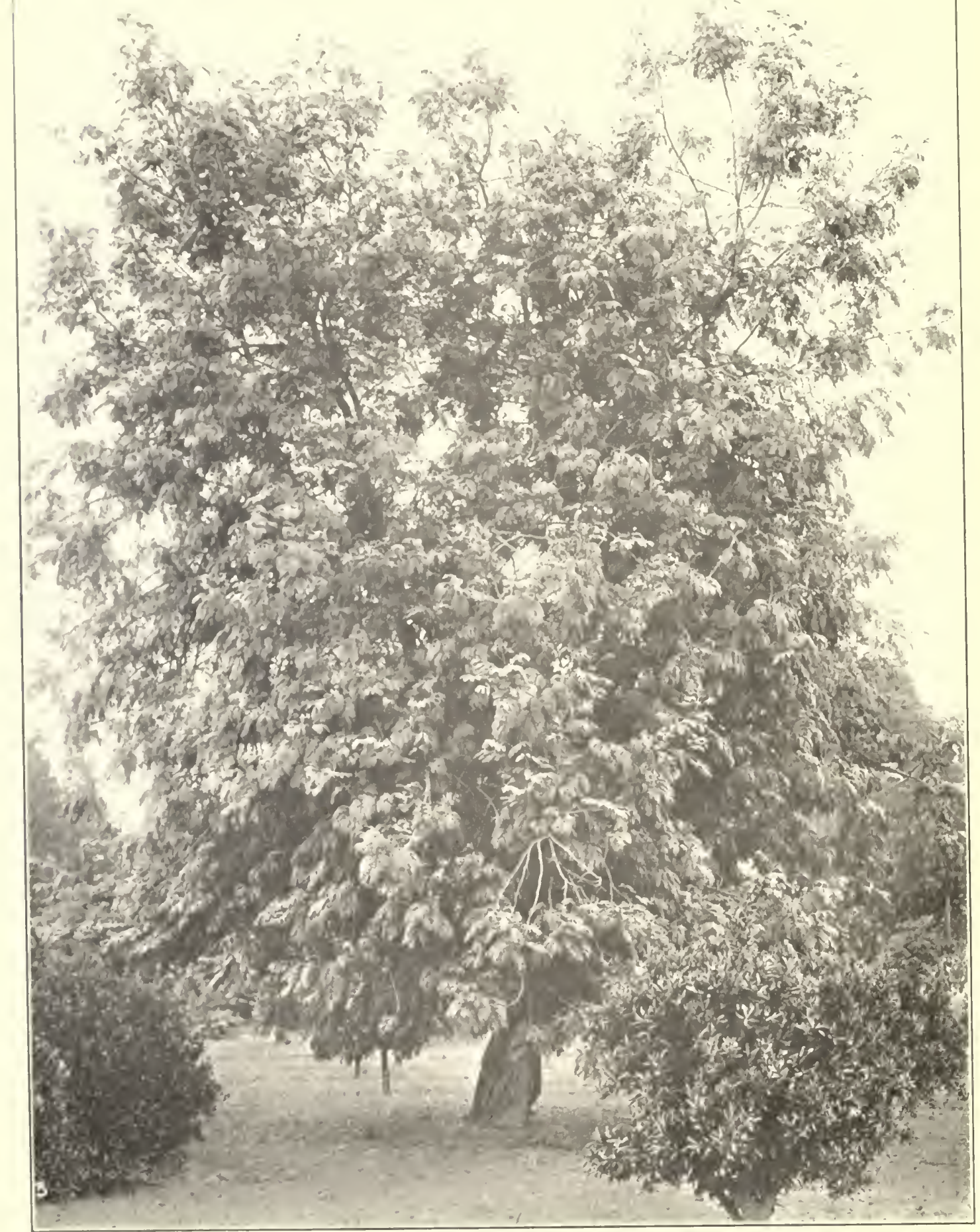

Plate 4. ACACIA ELATA, Los Angeles.

"But he only hearrl the gentle sigh

Of the summer breeze 
from thirty to fifty feet on all sides, give it a massive and picturesque appearance. Its appearance harmonizes with the lines of classical buildings, which has led artists to show it in pictures of terrace gardens of Babylon and Nineveh.

\section{Mount Atlas Cedar}

The Mount Atlas cedar (Cedrus atlantica) is a native of North Africa. It is probable that some of these cedars were sent by Hiram, King of Tyre, to Jerusalem, at the time King Solomon's temple was under construction. The appearance of this tree is similar to that of the Cedar of Lebanon except that it is more pyramidal in habit and the needles are a yellower shade of green. A variety of this cedar (Cedrus atlantica glauca) has silvery leaves which makes a striking contrast to the dark-green foliage of trees among which it may be planted. The Mount Atlas cedar is extremely hardy, and is one of the most beautiful ornamental trees that we have.

\section{Deodar, Indian Cedar}

The deodar (Cedrus deodara), called the "God-tree" of the Himalayas, forms forests in India at elevations ranging from '5,00 to 12,000 feet. Here it reaches a height of $\mathrm{I} 50$ feet and a diameter of six to eight feet under favorable conditions. When young it is a graceful pyramidal tree with pendulous branch-tips densely set with long dark bluish-green needles. The character of the foliage does not change as the tree matures, but the limbs become wide-spreading and stately. The striking deodars on the Capitol grounds at Sacramento command the attention of visitors, and are known throughout the country.

The beauty and effectiveness of the deodar as a road and avenue tree is beginning to be recognized. A drive at Kearney Park near Fresno is lined with these trees. Unfortunately the trees were spaced too close together which will make it necessary to take out every other tree in a few years to give room for development for the remaining trees. The tree does not 'tolerate freezing, but was noted in good growth from San Diego to Ukiah and Chico, which indicates that it can be planted through considerable range in the state. 


\section{THUYA}

The arborvitae belong to the genus Thuya, a word derived from the Greck signifying sacrifice, probably because the resin procured from the tree was used as incense. The Latin meaning of aborvitae is "Tree of Life," which signifies the reverence which prompted the name.

Arborvitae enbraces four species which are confined to northeastern and southeastern America, Japan and Xorthern China. Two species are native to America, one being the white celar of the northeastern United States, and the other, western red cedar, sometimes called the giant arborvitae or gigantic cedar.

Arborvitae are tall and symmetrical in their native state with a formal, conical habit. The branches are spreading with flattened branchlets corered with leaves overlapping like scales. Many garden forms have been developed which offer considerable variety of color and texture which are desirable features among evergreen foliage plants. They make beautiful lawn specimens, and are particularly effective near the border of water. Some varieties are well adapted for hedges since they bear pruning well. They are easily transplanted, are adaptable to a variety of soils and grow rapidly.

\section{Giant Arborvitae}

Giant arborvitae (Thuya gigantea), attains magnificent proportions in its native habitat on fertile bottom lands near Puget Sound and Vancouver Island where specimens 200 feet high and fifteen or sixteen feet in diameter have been found. From this tree the Indians have carved most of their massive totem poles some of which are fifty feet in height. These poles are strikingly colored and skilfully hewed into grotesque figures of men and beasts. The Indians also made war canoes from a single cedar log which were often sixty feet or more in length, eight feet across at the widest point, and capable of carrying a load upward of thirty tons.

Giant arborvitae does well under cultivation. It retains living branches almost to the ground, forming a stately and symmetrical spire of green. Young trees have slender, upcurving limbs, but as the tree increases in age it gradually develops a rounded top. The trunk is tapering with a fluted base on which the grayish-brown bark is separated into narrow strips by seans which extend irregularly the length of the trunk. It is without doubt one of our most handsome native trees. 


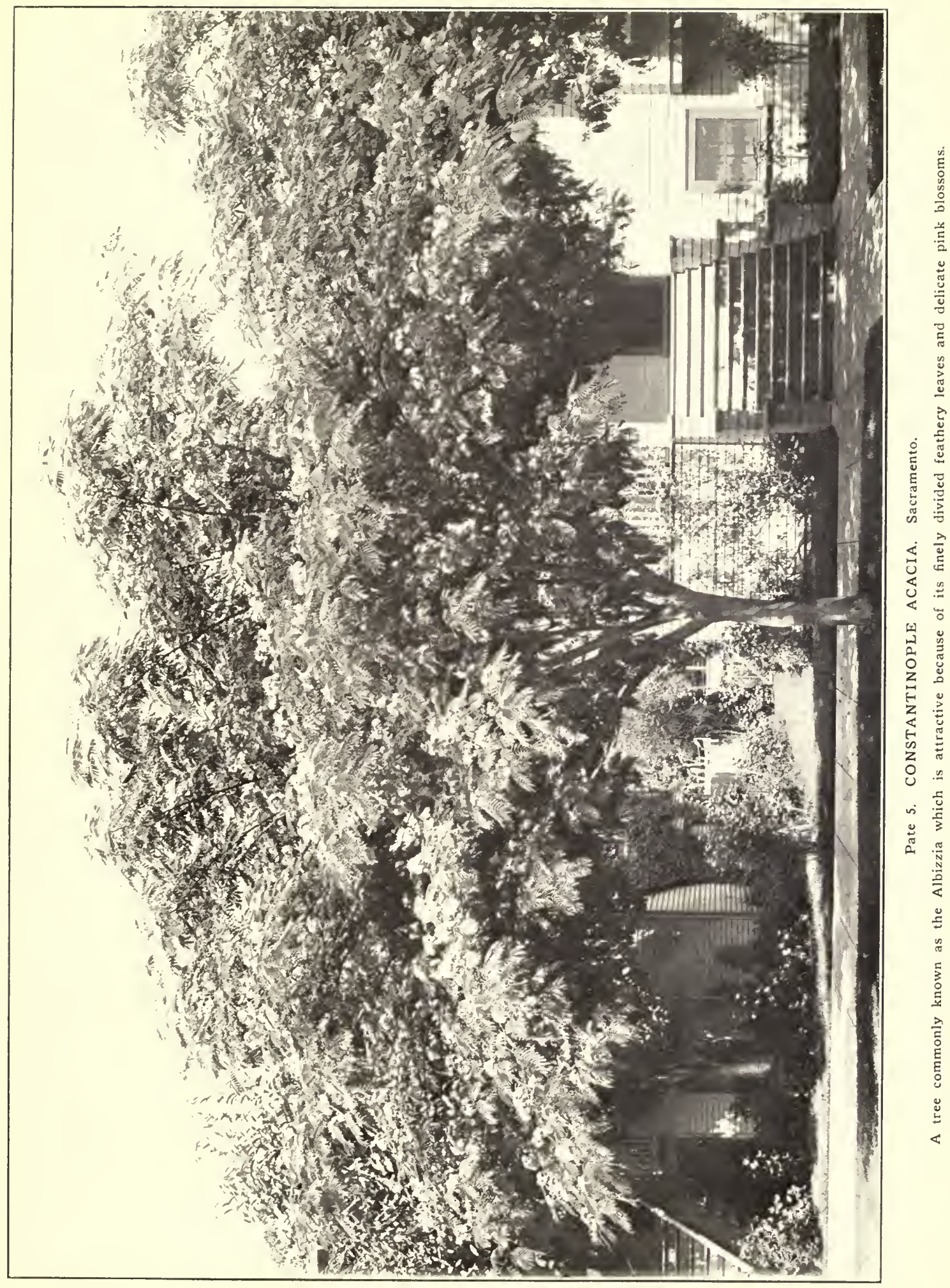




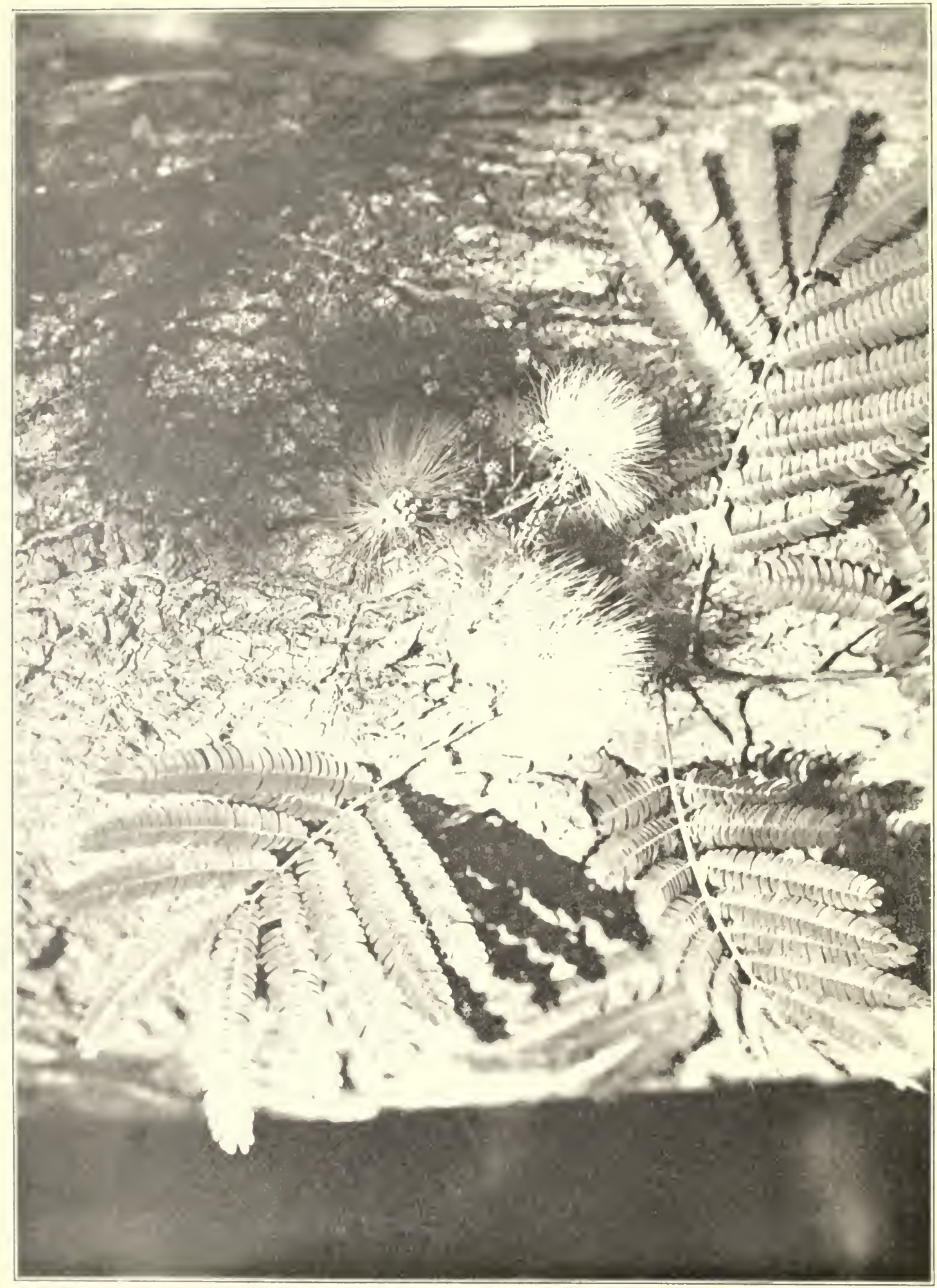




\section{Chinese Arborvitae}

The Chinese arborvitae (Thuya orientalis) has a dwarf habit and slow growth. It is almost globular in outline with bright green foliage which becomes golden or bronze tinted during the winter. A number of other variegated forms of arborvitae are handled by nurserymen, all of which have high decorative value.

\section{THUYOPSIS}

Japanese arborvitae (Thuyopsis dolobrata) is closely related to the genus Thuya, from which it is chiefly distinguished by its greater breadth and boldness of foliage, and by the white splashes on the under side of the leaves. In Japan it grows in moist, dense forests, under the shade of other trees. It is a beautiful conifer of pyramidal shape with the branchlets arranged in fan shape, much flattened and clothed with scale-like, glossy green foliage. It thrives best in a sheltered position in moist loamy soil, and is well adapted as a single specimen on a lawn. It grows better from cuttings than from seed.

\section{CUPRESSUS}

The cypress (Cupressus) was much admired by the ancients, and it was probably because of its reputation that the Island of Cyprus was so named. There is a myth to the effect that a youth named Cuparissos, a companion of Apollo, the Grecian divinity, was turned into a cypress tree upon his death, and that this tree was given the special function of shading the graves of those who have been greatly beloved in life. Mythology relates that the goddess Venus never appeared in the annual processions of Pan-Athenaic fame without a cypress bough made manifest in her retinue, a symbol expressive of her grief upon the death of Adonis.

Horace writes that whatever was thought worthy to be handed down to posterity by the ancients was enclosed in cypress or cedar wood. The Biblical ark, "pitched within and without," was made of gopher wood, which is supposed to have been that of the Italian cypress. Herodotus tells us that the Egyptians used cypress for their mummy cases. Plato directed that his code of laws should be engraved on cypress wood, as being more durable than brass.

The customs and languages of the ages have made cypress a symbol of bodily death and spiritual immortality. Its evergreen character, monumental 
outline, and balsanic odor, have no doubt contributed to the symbolism which Spencer summed up by describing it as "the Cypresse funerall."

Cypress is an extremely long-lived tree. Two cypresses planted hy A fichael Angelo are still living in Rome. In Lombardy is a cypress tree supposed to have been planted in the year of the birth of Christ. It is over 120 feet in height, and twenty-three feet in circumference. In addition to the interest which arises from its great age and size, this tree has the distinction of heing wounded by Francis I, who is said to have stuck his sword into it in despair after his defeat at Pavia. It is said that Napolcon so respected this tree that he deflected his road over the Simplon in order to avoid injuring it

The cypresses are tall or medium-sized trees with erect growth as a rule. The cones are globular in shape and when mature are about an inch in diancter The branches subdivide to form flat spravs which are closely covered with small overlapping leaves in four rows There is a curious Mohammedan superstition, existent among the natives of Ceylon, that he who eats a cypress leaf when it chances to fall to the ground, has his youth restored to him. Whittier depicts venerable saints as sitting patiently under the cypress trees of Ceylon waiting the falling of this much prized leaf.

\section{Monterey Cypress}

Monterey cypress (Cupressus macrocarpa) grow's naturally only in a restricted locality near Monterey Bay on the California coast. It is widely: planted throughout the state, its clense foliage making it especially valuable for windbreaks and hedges.

\section{Italian Cypress}

The ltalian cypress (Cupressus sempervirens) is a tapering, cone-like tree with a short stem below its branches, which gives it much the appearance of $\checkmark$ Lombardy poplar. Mature trees reach a height of about seventy-five fect. Its columnar form gives it a formal effect which is much used in gardens and for architectural effect. It makes splendid avenues like those of the beautiful villas in Italy, but will lose its character if planted in rich soil and with plenty of moisture. In such cases its lateral branches spread out under the overweight of foliage.

The Italian cypress is very successful in architectural schemes as evidenced hy its use at the Villa Borghese in Rome. Professor Neuhaus states 


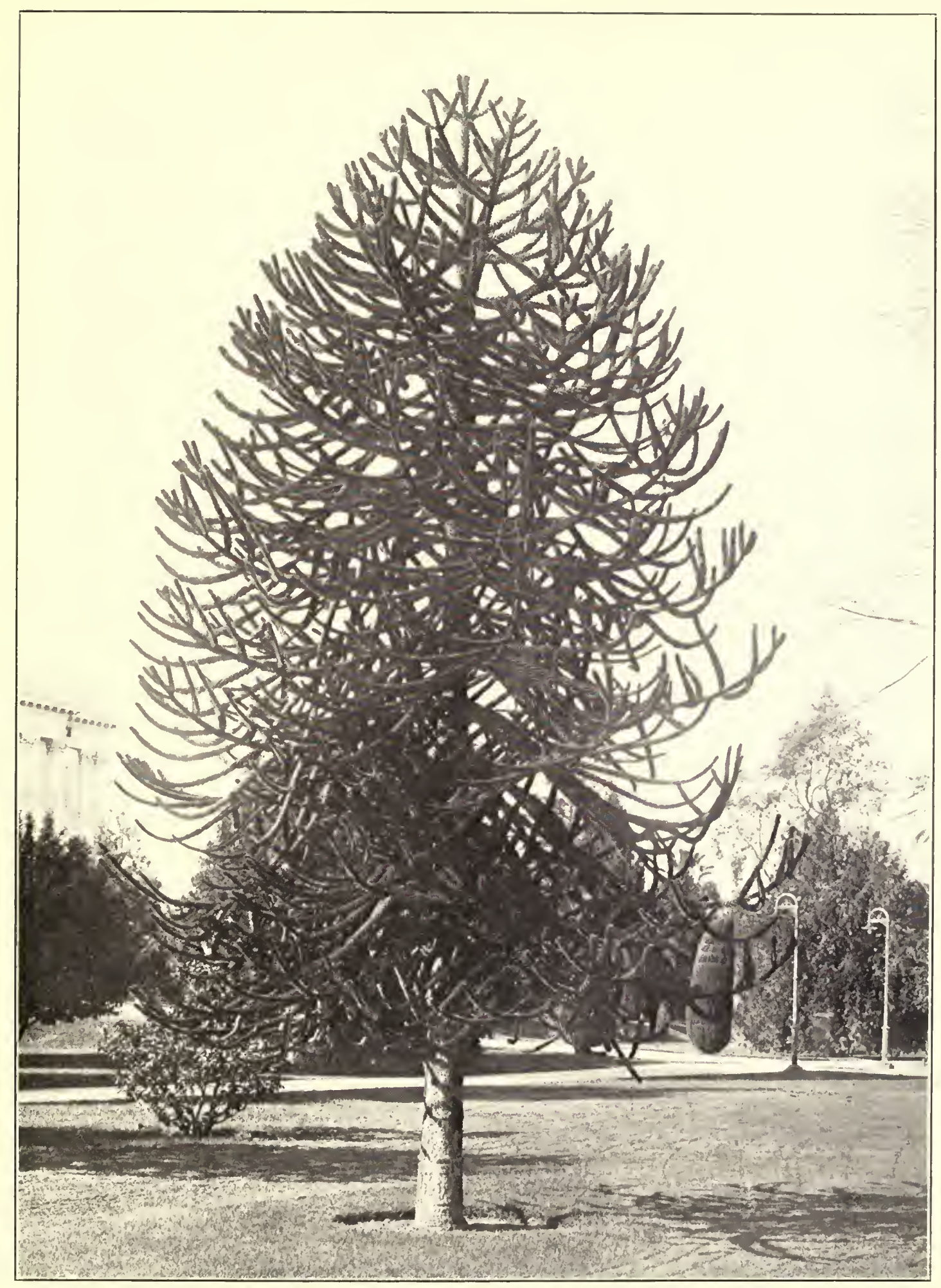

Plate 7 MONKEY PUZZLE. Sacramento.

A native of Chile, where it forms forests on the Cordilleras. It gets its name from its twisted branches which it would puzzle a monkey to climb. 


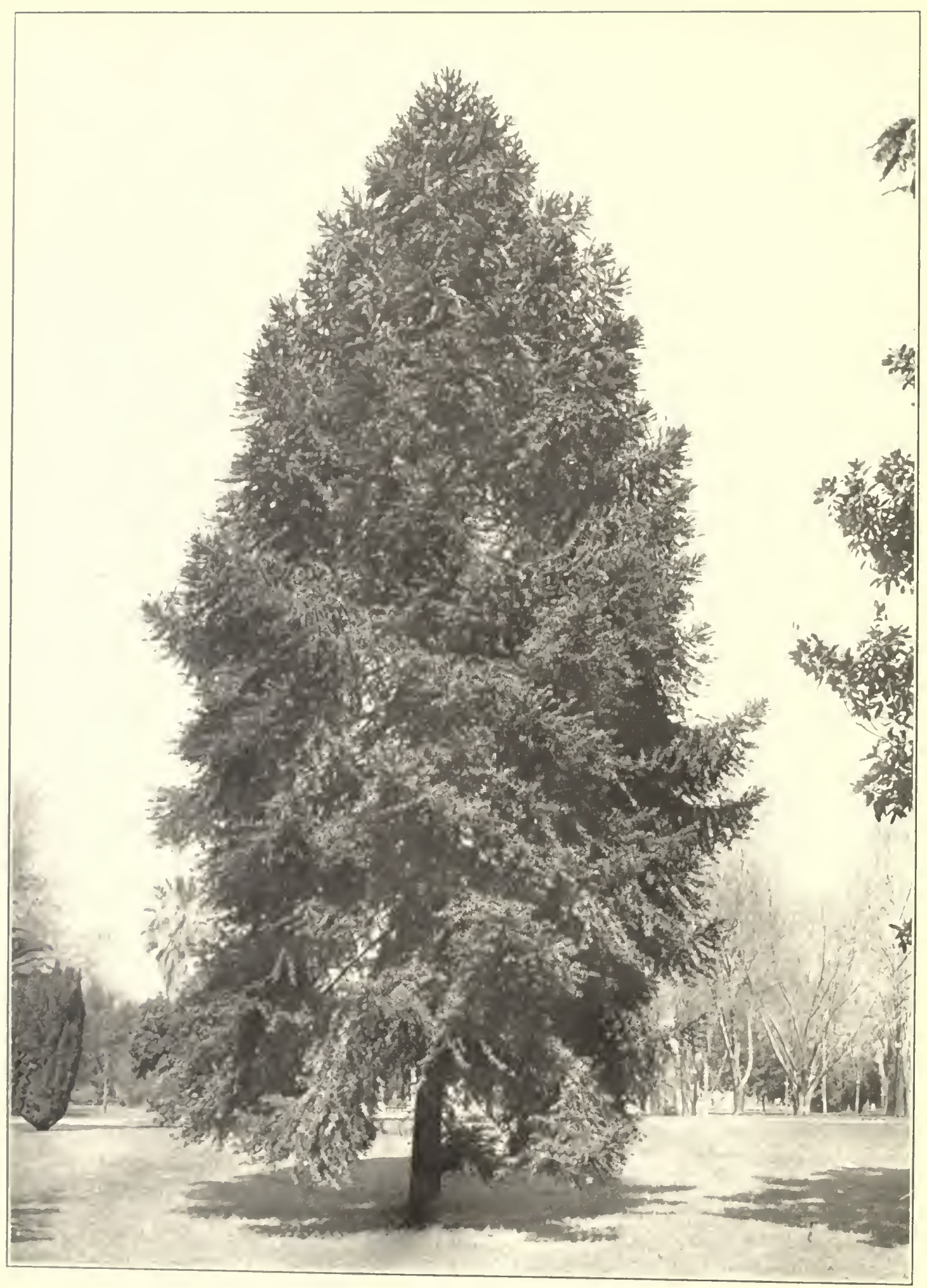

Plate 8. BUNYA.BUNYA. Sacramento.

A natuve of Queensland, where it reaches a height of 150 feet. The cones are as latge as a man's head and bear 


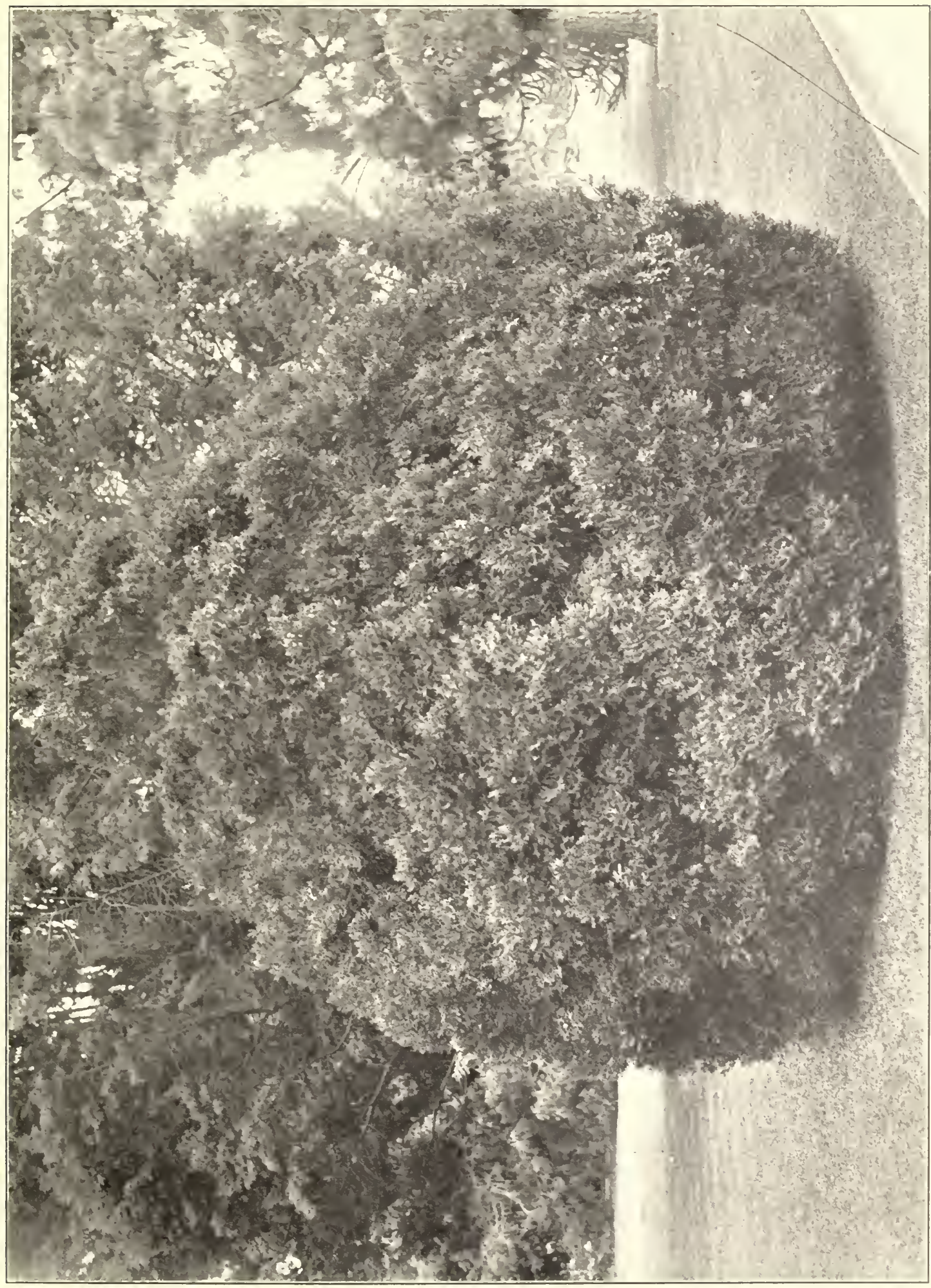




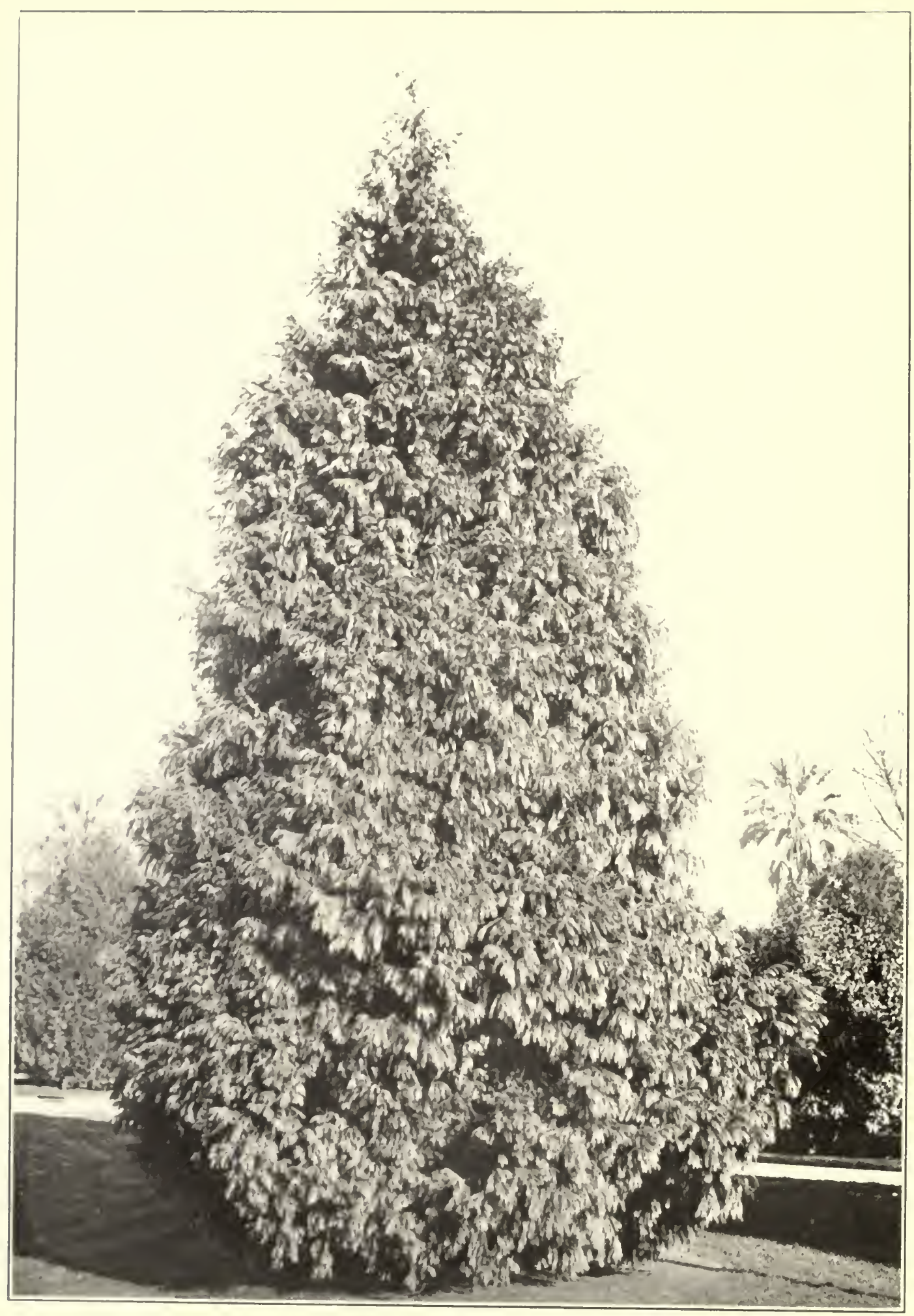

Plate 10. GIANT ARBORVITAE. Sacramento.

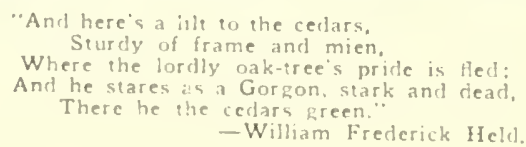


that the effectiveness of the Court of Palms at the Panama Pacific Exposition was largely due to the liberal use of these elegant trees with their somber stateliness.

\section{Guadalupe Cypress}

The Guadalupe or blue cypress (Cupressus guadalupensis) does not seem to be as short-lived as the Monterey cypress. It is about seventy feet in height, and has a striking blue color to the foliage. It does well on dry, rocky locations similar to its native habitat on Guadalupe Island.

\section{Arizona Cypress}

The Arizona cypress (Cupressus arizonica) from the mountains of northern Arizona has a handsome, brilliant blue foliage. It does not attain the height of the Guadalupe cypress, but will stand more cold and drought.

\section{CHAMAEC YPARIS}

The genus Chamaecyparis is closely related to Cupressus, and for purposes of distinction its members may be called the "flat-branched cypresses," since the branchlets are always arranged so as to lie in a plane. The branchlets are drooping and feathery in appearance.

The genus embraces five species, one of which is found in eastern United States, two on the Pacific Coast and two in Japan. The Japanese have propagated several nursery varieties some of them being dwarf-like in habit. The species which grow on the Pacific Coast in this country reach a height of 200 feet or more and are valuable lumber trees. The name Retinospora is applied to some Japanese species of this genus with juvenile foliage retained by artificial methods of propagation.

\section{Lawson's Cypress}

Lawson's cypress (Chamaecyparis lawsoniana) the garden term for the forest tree known to lumbermen as Port Orford cedar, grows naturally in restricted areas in Oregon and California. It was introduced into cultivation shortly after its discovery in 1854 . As an ornamental tree it has a striking appearance because of its horizontally spreading pendulous branches, and flat compressed foliage. The lowest branches usually persist and spread widely so that the pyramid rests directly on the ground. On account of its broad 
base. this tree should not he planted closer than forty fect to other trees It is not well adapted for parkings, hut makes a heautiful lawn specimen.

Lawson's cypress is prized by nurserymen, who have developed at least sixty forms in color and habit from it. One of the most striking is the Goldien Lawson cypress, the young growth of which has intensely ycllow foliage. ()ther forms have foliage of rich green or a bluish metallic hue. The Japanese forms are usually shrubs or very small trees. The Hinoki cypress (Chamaeyparis oblusa) is a favorite Japanese dwarf tree.

\section{LIBOCEDRUS}

The genus Libocedrus embraces eight species, one of which is found on the Pacific Coast in this country, two in Chile and five in the region from southwestern China to Xew Zealand. The trees are large with pyramidal habit, and graceful emerald foliage. In many ways they resemble Law'son's cypress except that the pendent character of the tips of the branches is distinctive. They thrive best in well drained soil, but are hardy and withstand considerable drought when once established.

\section{Incense Cedar}

Incense cedar (Libocedrus decurrens) occurs naturally chiefly in the Sierras of California where it is found growing at elevations ranging from 2000 to 5000 feet in the north and from 3000 to 7000 feet in the.south. The average height is from seventy-five to 110 feet and the average diameter from thirty to forty inches. The largest trees are 150 feet in height and ninety-six inches in diameter.

Incense cedar was first observed by Fremont on the south fork of the American River while on his record expedition in $18+4$. It is widely planted as an ornamental and forms a beautiful specimen with its abundant semidrooping foliage and columnar habit. It is not greatly disfigured by the removal of the lower branches as is the case with so many conifers. As a rule, however, it is not advisable to remove the limbs of a conifer used as a specimen tree since this practice is apt to mar its beauty. 


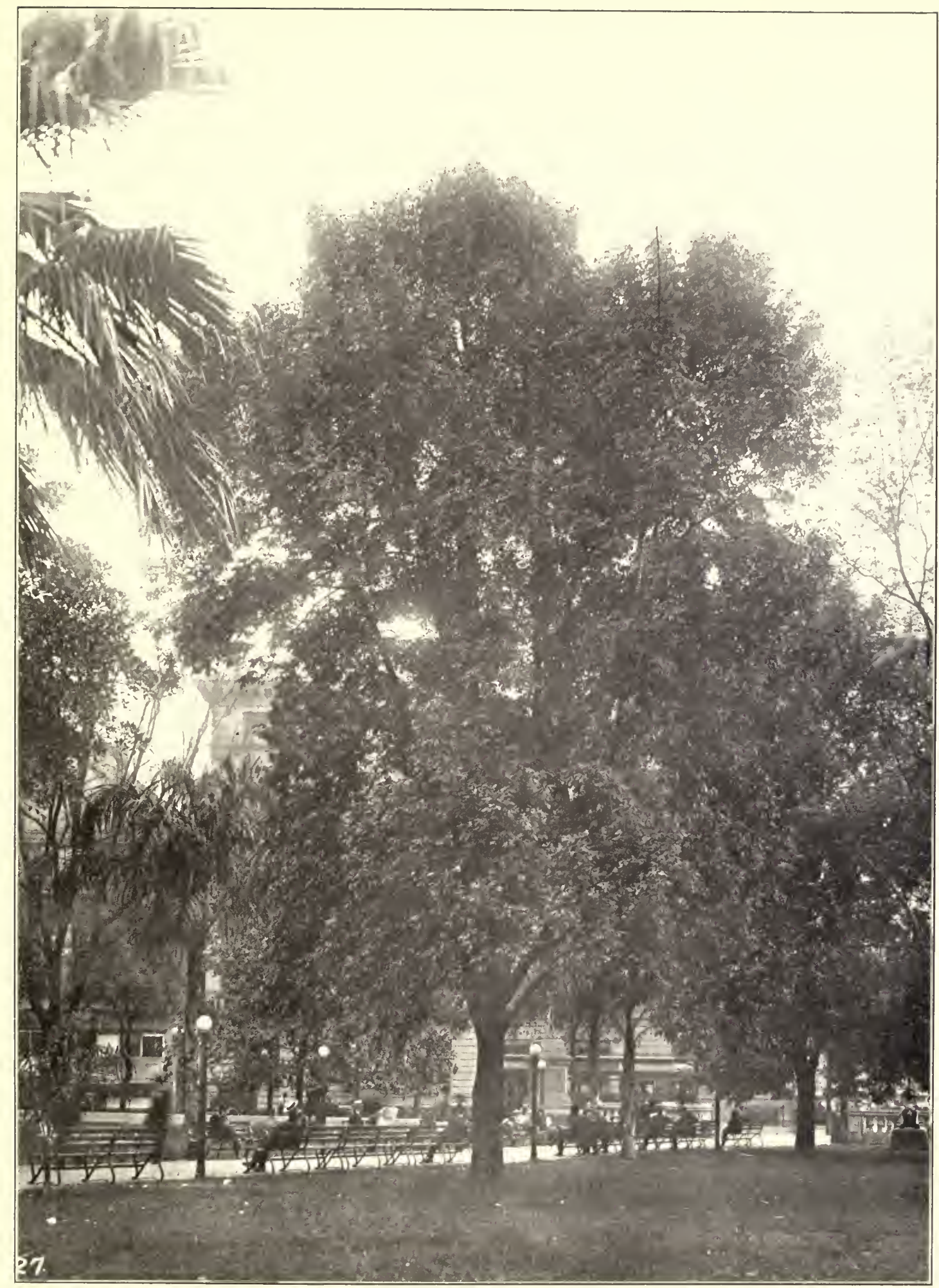

Plate 11. ARIZONA ASH. Los Angeles.

A tree that is destined to be widely planted in California along roads and highways because of its ability to do well under adverse conditions of soil and moisture. 


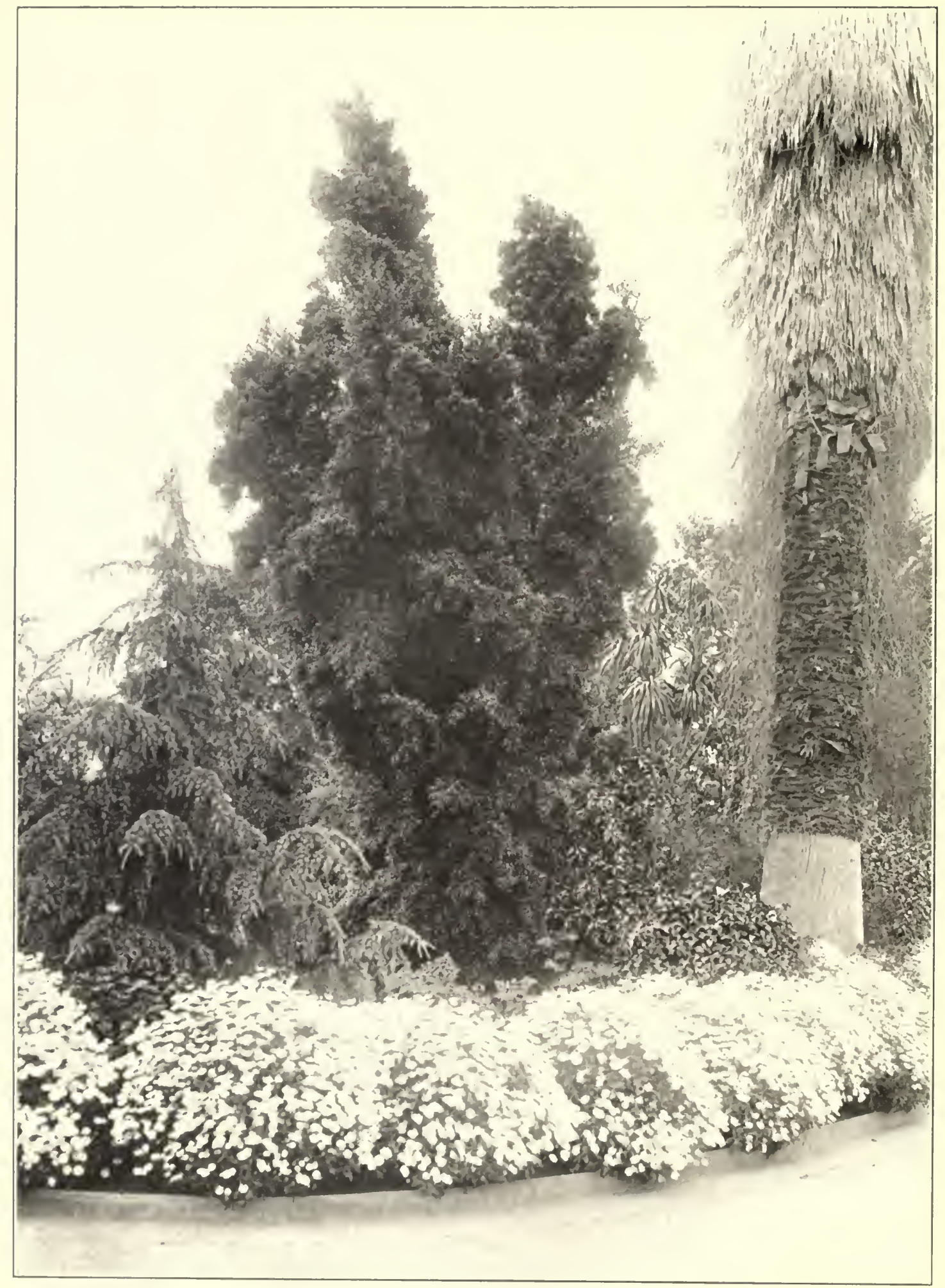

Plate 12. AUSTRALIAN BRUSH CHERRY. Pasadena.

An Australian tree with murtle-like foliage and blossoms which is widely used by landscape gardeners. 


\section{BALD CYPRESS}

Bald cypress (Taxodium distichum), which traces its descent from a very ancient family, is one of the few coniferous trees that sheds its leaves in winter. This habit of becoming "bald" in winter gave rise to its first name. The genus embraces three species, two in North America and one in China. In this country the bald cypress which grows naturally in the swamps of the South Atlantic and Gulf regions is the only one that has a commercial value. It is one of the very few species of trees that will adapt itself to extremes of moisture in the soil.

In its native habitat bald cypress reaches a height of 150 feet and a diameter of four or five feet. The lower part of the trunk bears huge buttresses, each of which ends in a long branching root from the branches of which spring knees which rise above the level of the water. The knees are of a soft spongy texture, and it is supposed that they act as breathing organs, supplying the roots with air which they would otherwise be unable to obtain when submerged.

Bald cypress has stout horizontally spreading branches and leaves somewhat like those of the redwood. The light green feathery foliage gives the tree a most graceful appearance. Under cultivation the knees are usually absent. This tree does not stand intense cold, but is adaptive to many soil conditions, and grows rapidly, even in a dry soil. Splendid specimens of this tree are to be found in Berkeley.

Of the two related species of bald cypress, one is a shrub native to China, the other a large tree found in Mexico called the "Cypress of Montezuma" or "Evergreen cypress" because of the fact that it retains its leaves throughout the year. This tree was reverenced by the Indians long before the discovery of America. It is widely planted in parks in Santa Barbara and has a striking individuality because of its distinctive color and form.

\section{SEQUOIA}

The genus Sequoia embraces two giant species which are the most magnificent trees in the world, and which justly rank with its natural wonders. The term Sequoia is in honor of an Indian Chief named Sequoyah, the inventor of the Cherokee alphabet. This genus together with closely related groups once spread over the entire northern hemisphere. Fossil remains have been 
found in Europe, Spitzhergen. Siberia, Mlaska, Canavla and Greenland. Sequoia flourished millions of years ago when the linosaurs were the most advanced form of land animals, and before the rocks that constitute the present Sierras and Coast Ranges in California were laid down in the shallow seas, to be later upheaved and carved to their present shapes. Toulay only two kinds of Sequias are in existence and their nearest living relative is the bald cypress of the Southern States. They are the oldest living thing on earth, and have probahly never heen surpassed by any trees in the ages gone by in size, height or grandeur

\section{Redwood}

Redwool (Sequia sempertirens) the "Palo Colorado" of the SpanishAmericans, is found in its natural state only on a strip 450 miles long and twenty miles wide, extending from southwestern Oregon to Mlonterey County in California where it was first discovered in 1791

John Muir speaks of the redwood as the glory of the Coast Range. Trees from 300 to 350 feet in height and ten to twenty feet in diameter are not uncommon and their graceful beauty is enhanced hy the garden at their feet of fresh, exuberant ferns, lilies and rhodoclendron. The age is about half that of its cousin in the Sierras, running from 500 to 1300 years.

Redwood has bright, deep green foliage which consists of two forms of leaves, one of them narrow and flattened with stiff, sharp points and the other scale-like and closely overlapping. The young tree forms an attractive nyramid of dense foliage which becomes conical in appearance as the tree matures. Redwood requires a cool, humid atmosphere for its best development. It has been successfully planted in many parts of the state as arenue and specimen trees.

\section{Big Tree}

Big tree (Sequoia gigantea) is found only on the western slope of the Sierra Neradas in California at an altitude of from five to eight thousand feet above the sea, with a north and south range of about 250 miles. It occurs in thirtytwo more or less isolated groves, one of the best known being the Calareras Grove. It is said that the big tree was first discovered in this grove in 1852 by a hunter in the pursuit of a bear. 


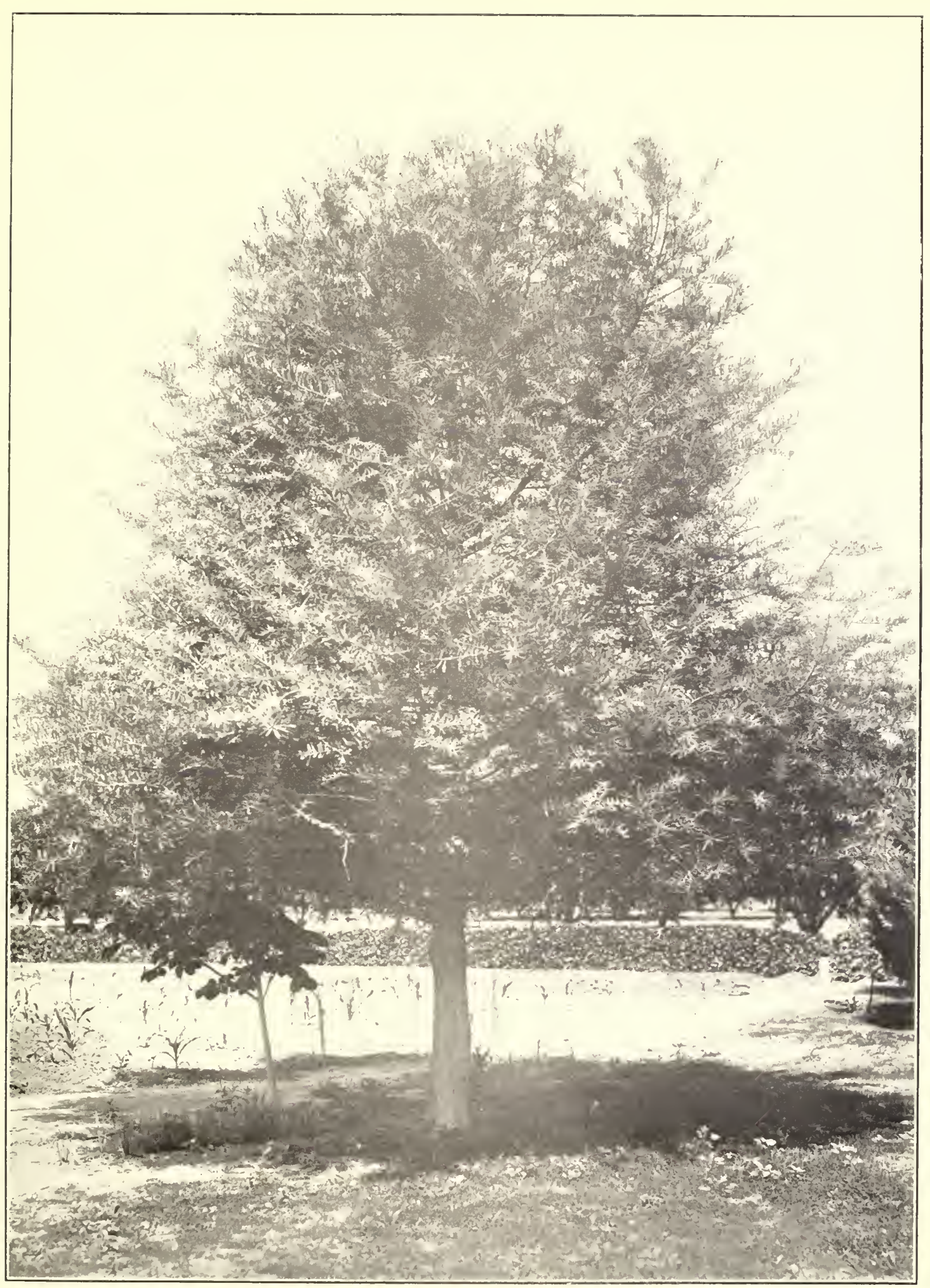

Plate 13. BALD CYPRESS, Exeter.

A tree that traces its descent from a very ancient family. Its habit of becoming "bald" in the winter, through shedding its needles, gives rise to its first name. 


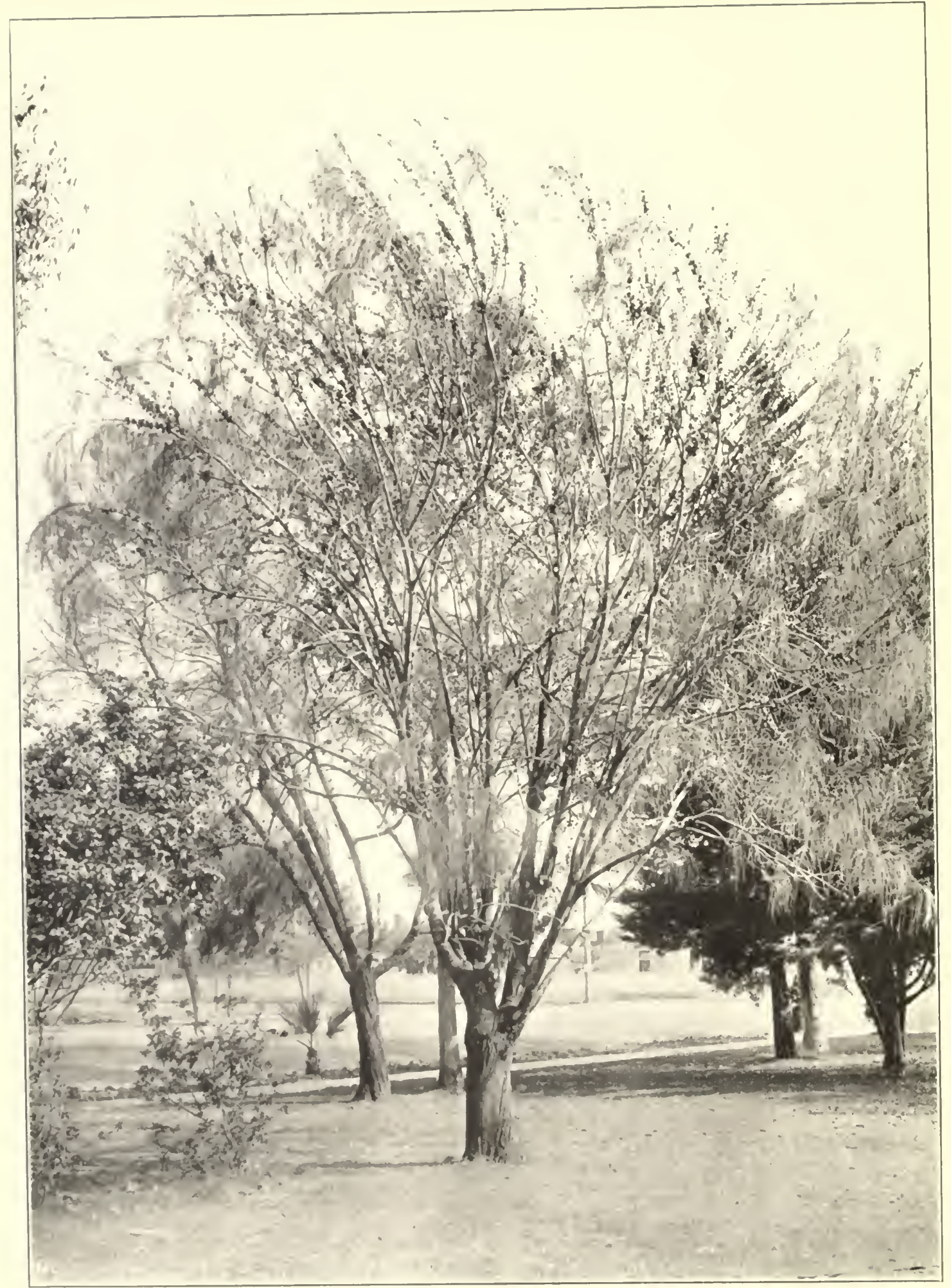

Plate 14. SHE OAK. San Diego.

Australian drouphi-resisting tree with hranches jointert like those of the equisetums. of the cassowary, a large burd of the East Indies. 
Big tree is the largest tree in the world. The General Sherman Tree is 280 feet high with a diameter of thirty-six and one-half feet. The General Grant Tree is 264 feet high with a diameter of thirty-one feet. The known ages of trees which have been cut is from I 100 to 3250 years, but it is probable that some of the largest standing trees may be of greater age.

Big tree has been widely planted and does well in deep, rich soils. It has a straight trunk with thick branches which at first are ascending, but later curve downwards. The light green leaves are spirally arranged around the branches. It makes a handsome lawn specimen, but should be given plenty of room to develop a regular, conical outline

\section{JUNIPERUS}

The junipers (Juniperus) are widely scattered over the northern hemisphere extending as far north as the Arctic Circle and as far south as the mountains of east tropical Africa and central China. This genus embraces about thirty-five species, eleven of which grow naturally in the United States. The best known is the southern red cedar (Juniperus virginiana), an eastern species which furnishes most of the pencil wood.

Junipers are small trees or shrubs of pyramidal or columnar form and as a rule have two kinds of foliage which are often found on the same tree. Cne form of leaves are needle-like and prickly. while the other form are scalelike, overlapping and arranged like those of the cypresses. The origin of the name of Juniper is to be traced to the Latin words juvenis (young) and the verb parere (to produce). It was probably so named on account of its habit of producing the two entirely different looking set of leaves. The junipers differ from most of the conifers in bearing small berry-like fruits instead of cones. The fruit of the juniper is used to give gin its flavor.

The juniper has its accompaniment of myths and legends. It was consecrated to the Furies, the smoke of its green branches being the incense offered to the Infernal Gods, while its berries were burnt at funerals to keep off evil spirits.

In the Bible much is written about the juniper in the wilderness where it conferred the blessings of both shade and food to many a weary traveler. Job pictures such a one who made a meal off the fruit of a juniper bush under which he rested. On the other hand, Dr. Johnson, the renowned lexicographer, 
stated that its taste was bitter and its shade had a baleful influence on man and kieast. II c can find no hasis for these assumptions, and accept the juniper as a tree of graceful beauty in our lawns and gardens.

The junipers are adaptive to adverse soil and atmospheric conditions and will thrive on rocky hillsides or along the seashore where living conditions are harsh. Their grow th is slow, and they are less symmetrical than most conifers, but their hardiness and freedom from pests make them valuable trees on arid locations. Of the cxotic species cultivated in California the most common are the European and Japanese forms.

\section{California Juniper}

The California juniper (/uniperus californica) is a small tree of spreading habit which grows naturally in dry situations. The foliage, which is a deep rich green, is borne on a broad open head. It is not commonly cultirated by nurseries, but small transplanted trees should do well because of the ability of the tree to resist adverse soil and moisture conditions.

\section{Creeping Japanese Juniper}

The creeping Japanese juniper (Juniperus chinensis procumbens) is a dense, dwarf shrub with trailing branches and glaucous foliage. It is well adapted for rock gardens, or for forming groundwork for hiding bare ground under large trees.

\section{CR YPTOMERIA}

Japanese cedar (Cryptomeria japonica) claims a Greek origin for its generic name. The Greek word, kryptos, signifies hidden, and the word meros, part, and it is supposed that this tree was so christened on account of a hidden relationship with the cedar. It differs from the cedar, however, in many respects. It has long, awl-shaped leaves and loose, open branches which ascend at the extremities. The bark, which is cinnamon colored, peels readily from the larger trees. It is a large pyramidal tree at maturity with a distinguished appearance, which is probably the reason it is called "Peacock Pine" by the Chinese. There is a variety known as elegans which has very fine and feathery foliage which changes from a rich green in summer to a bronzy red in winter. 


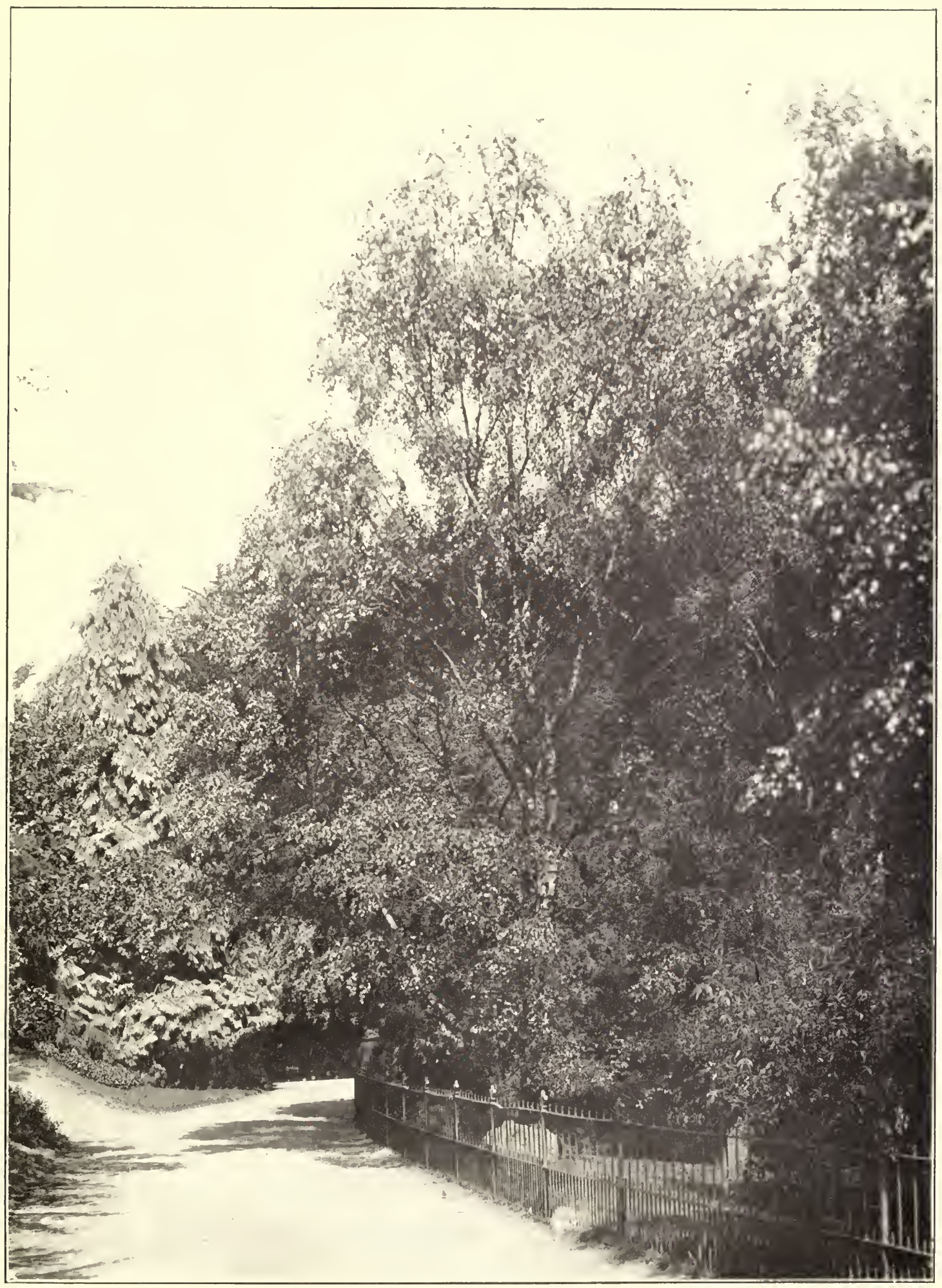

Plate 15. WHITE BIRCH. Golden Gate Park.

"The birch, most shy and ladylike of trees." 


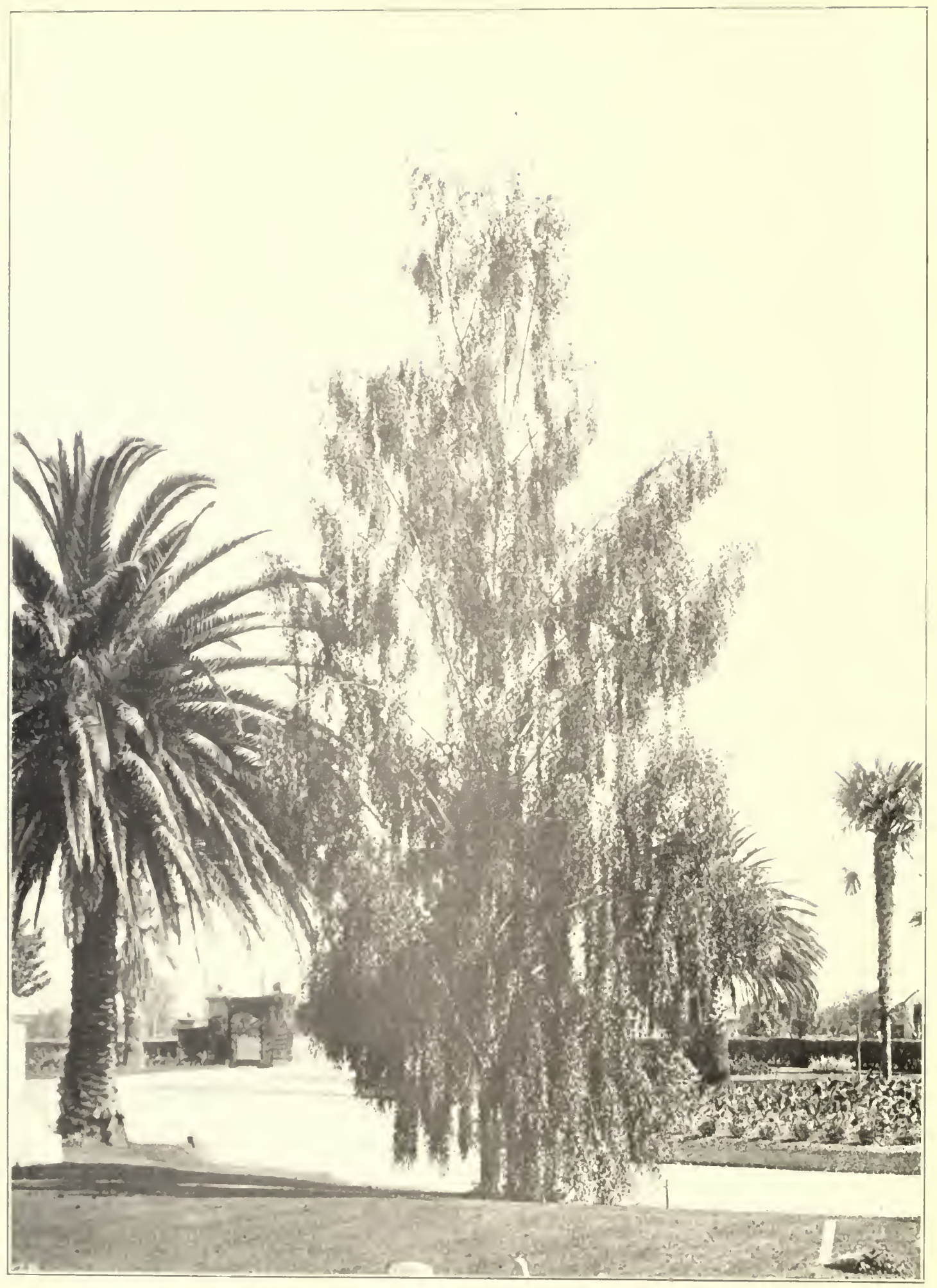

Plate 16. WEFPING BIRCII. San Jose. 
An interesting feature of this tree, which is the national tree of Japan, is its antiquity. Its lineage, like that of our Sequoias, can be traced to a very remote geological period In Japan it forms extensive forests towering above undergrowing ferns, mosses, and lichens as do our redwoods.

\section{DOUGLAS FIR}

Douglas fir (Pseudotsuga taxifolia) derives its formidable generic name, which means "false hemlock," from a combination of a Greek with a Japanese word. The name indicates its relation with the hemlocks, but it has botanical differences which caused it to be classified as a distinct genus. This tree goes under the name of red fir, Oregon pine, and Douglas spruce, but the commonly accepted name among foresters is Douglas fir. It was collected in 1826 by David Douglas, a Scottish botanist who was sent to the United States as a collector by the Royal Horticultural Society. Few men are commemorated by a more impressive monument since Douglas fir is one of the most important timber trees in the world. It grows throughout the Pacific Coast region and the Rocky Mountains from British Columbia to northwestern Texas, Mexico and the mountains of California, a range of over 2000 miles from north to south and nearly iooo miles from east to west.

With the exception of redwood, no other tree of our continent attains larger size. The tallest Douglas fir on record has a height of 380 feet. Trees fifteen feet in diameter are not uncommon and single trees have been cut that scaled 60,000 feet, board measure. On the lowlands of the north Pacific Coast the trees stand close together, with trunks forming cylindrical columns as straight as arrows and almost without branches for 200 feet. A flagstaff now in the Kew Gardens in England came from a tree felled in British Columbia. It is 159 feet long and tapers from a diameter of twenty-two inches to one of eight inches.

Douglas fir is readily distinguished from all other native cone-bearing trees by the feathered appearance of the cones which is due to flexible bracts that extend beyond the cone scales. The leaves are blunt at the point and soft and flat with tiny stems which permit them to arrange themselves, feather like, on opposite sides of the branches. In reality they are spaced all the way around the branch, and the successive leaves form spirals. 
When Douglas fir is planted as an ornamental the growth is erect and very rapid. It has graceful proportions and a rich, lark green foliage which has a feathery appearance on the pendulous hranchlets. The pendent cones add to its beauty. It is adaptive to soils, hut prefers lighter ones. To emphasize its beaut! it is best planted as a single tree.

\section{FIRS}

The true firs (Abies) embrace some twenty-three species which chiefly occur in the mountainous regions of the northern hemisphere. That fir has a place in history is revealed hy. Virgil's description of the woolen horse of Troy which was constructed from fir from \lount lda

"The leaders of the Greeks * * * build, with the aid of the divine skill of Pallas, a horse as huge as a mountain. and form the sides of interlacing planks of fir."

In these days fir is not highly regarded as a timber tree on the Pacific Coast where about a third of all known species are native, but it has a high value as an ornamental tree. The firs are distinguished for their symmetry and formal branch habit. The branches are arranged in tiers, and by side branching form wide, flat sprays, covered with blunt-pointed, flat leaves, the under sides of which are a silvery-white. The needles are stemless, and the cones, which are erect, fall to pieces at maturity, leaving a slender, woody axis on the tree.

The firs endure much shade, and make a rapid growth in a cool, moist atmosphere and on a well-drained soil. They are rather short-lived and are apt to suffer from drought, frost and fungi.

\section{WHITE FIR}

White fir (Abies concolor) also known as silver fir, is a beautiful tree that is common in the Sierra region of California. It has long. slender, light-green needles which form a decided contrast with its ashy-gray bark. The growth is very regular and symmetrical, which makes the tree effective whether in groups or singly in the park or lawn.

\section{NORDMAN'S SILVER FIR}

Vordman's silver fir (Abies nordmanniana) is a native of the Caucasus Mountains, where it attains a height of 150 feet. Under cultivation it grows 
slowly but eventually becomes a large tree. The branches are wide spreading and the foliage rich and lustrous, dark-green above and silvery underneath. This is one of the best firs for ornamental purposes, since it is hardy and retains its fine form for a long period.

\title{
SPANISH FIR
}

Spanish fir (Abies pinsapo) is a small tree which is of interest because of its rigid, acute leaves which entirely surround the branchlets. It is planted chiefly as a specimen tree, and is best adapted to a warm climate.

\section{SILVER FIR}

The European silver fir (Abies pectinata) reaches a height of 150 feet in its native haunts. It towers far above its companions of the woodlands, which led Hood to say:

\author{
"I remember, I remember, \\ The fir trees tall and high, \\ I used to think their slender spires \\ Were close against the sky."
}

This silver fir does well in California, particularly in Berkeley, where it forms a dignified ornamental tree. It resembles Nordman's fir except that it has shorter leaves and usually more open growth. The needles are dark, glossy green above and silvery beneath.

\section{GINKGO}

The ginkgo (Ginkgo biloba) often called the maidenhair tree because of the resemblance of its foliage to that of the maidenhair fern, is a native of China and Japan. The ginkgo was introduced into this country not many years ago from England. It is a remnant of a widely represented genus of ancient times, and has been preserved for ages about the temples of the Orient.

There is a ginkgo standing in a courtyard of a monastery in the vicinity of Peking which is said to have been planted by Emperor Yung Lo (13601424). The Chinese name, Pai-kuo-shu (white-fruited tree) is derived from the appearance of the fruit.

The tree is a botanical curiosity, for although it is classed with the conebearing trees, it bears fleshy fruit instead of cones and broad, fan-shaped 
deciduous leaves instead of needles.] The flower largely determines its position in botanical classification, the staminate and the pistillate flowers being borne on different branches of the same trec. The female flowers consist of two naked orules which receive the pollen. These ripen into the fruit of the ginkgo, which resembles a small plum. The fleshy part is ill-scented, but the kernels, which have a sweet ish flavor, are highly esteemed for food and for their medicinal value by the Chinese.

The ginkgo is a picturesulue tree, due to its straggling branch habit and irregular, open, conical form. It seldom exceeds a height of sixty feet in the Orient and in this country its maximum height is about forty feet. It is becoming a favorite tree for street planting because of its upright habit, attractive foliage and apparent inmmunity from insect injury. The leaves are clear green in the spring and early summer, changing in the fall to a soft yellow shortly hefore defoliation.

Exquisite landscape effects may be obtained by planting the ginkgo in lawns and parks, especially where it is massed with decictuous trees and shrubs with leathery, lark green foliage. It is also a good street tree and in Washington, D. C., lines an avenue leading to the Agriculture Building.

\section{PINES}

The Greeks dedicated the pine to Bacchus, and its cone, the symbol of fecundity; decorated that god's thyrsus. Its evergreen character is accounted for by an ancient legend. Atys, a Phrygian shepherd. loved Cybele, the mother of the gods, and vowed to be ever faithful to her. He broke his vow, and she in anger changed him into a pine tree beneath which she spent her time mourning. Jupiter sought to comfort her by pronising that the pine should never be bereft of its leaves.

The pine has been termed the Acolian harp of the forest. Richard Jeffries describes its music which forever floats upon the breeze as follows:

"Over in the field the row of pines was sighing; the wind lingered and clung to the close foliage, and each needle of the million million leaflets drew its tongue across the organ blast."

The pines embrace about seventy species and its members excel all other cone-bearing trees in the extent of area occupied, and in usefulness and importance to the human race. Some species are found on clry soils, and some in 


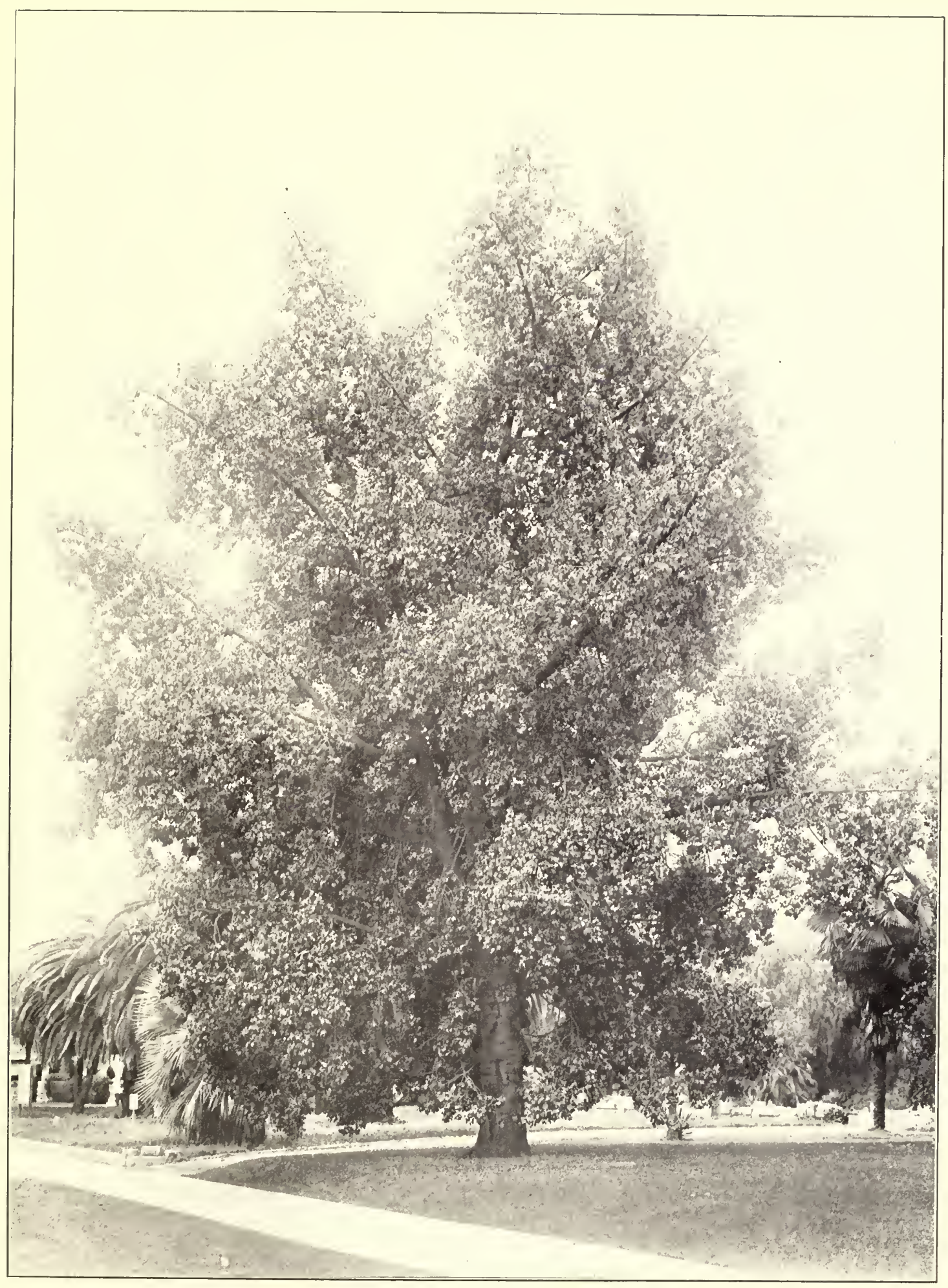

Plate 17. VICTORIAN BOTTLE TREE. Pasadena.

An Australian tree with a peculiar pyramidal trunk growth and bright glossy leaves of many different shapes. 


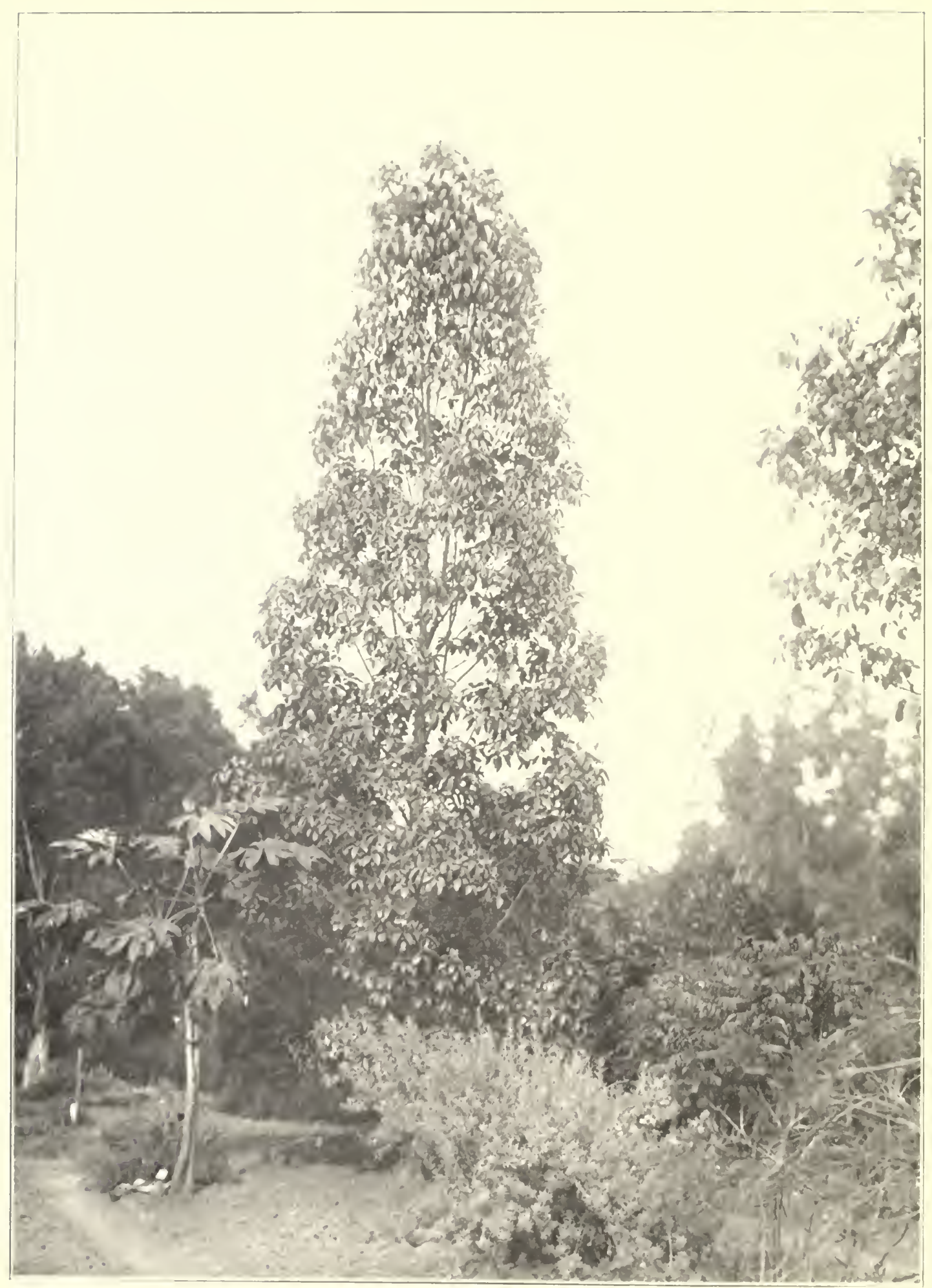

Plate 18. LRISBANE BOX. Berkeley. 
swamps, with representatives ranging almost to the Arctic and to near the equator. Some of the pines are tall, like the Norwegian pines which Milton refers to as mere wands compared to the spear which Satan used "to support uneasy steps over the burning marl," and some are mere shrubs at timber line.

The pines are closely associated with the development of this country. When the Pilgrims landed at Plymouth they beheld the white pine "on a stern and rock-bound coast," and adopted it as their emblem on the historic pine tree shilling. Later, Maine became a great producer of white pine and is still called the Pine Tree State. In 1635 a cargo of white pine masts was shipped to England, and cargoes of lumber were sent from New England to Africa to be paid for in slaves that were sold in Virginia and the West Indies.

The pine forests of the southern United States have long furnished more pine lumber than any other closely related group of timber trees in this country, but these once extensive forests are now disappearing even as did the white pine of New England and the Lake States. The pines of the Western States, which include the sugar pine, the largest of the pines, and the western yellow pine, are now being cut and shipped to the East where pine was formerly so abundant.

Although the pines are known chiefly for their value for timber, yet there are a number of species which are highly ornamental. By the use of large masses and proper variety as a background, a characteristic sky-line can be secured which cannot be excelled by the use of any other group of trees. The pines have a less formal habit than the spruces, and not as dense a foliage. The needles are long, in bundles of from one to five, and on old trees are crowded in tufts to the end of the branches. The conical form of young trees changes at maturity to a broad, flattened crown of picturesque appearance. Pines have a touch of mistiness due to their form and coloration which led Tennyson to connect their thick boughs with "many a cloudy hollow." All the pines are light-needing, but are easily handled and under favorable conditions make rapid growth.

\section{STONE PINE}

The stone pine (Pinus pinea) is the first pine mentioned in ancient writings. There is a myth of ancient Greece that Pan, the god who presided over country regions, attempted to win the love of a nymph of Mount Taygetus, 
where he then had his abode. Boreas, the god of the north wind, became a rival of Pan and, in a fit of anger, blew the nymph down from a high precipice. Pan saw her falling and though unable to save her life changed her form to that of a pine tree. From that time pine trees have been seen clinging to rocky mountain sides and growing in the exposed places of the earth.

The stone pine is a conspicuous feature in the landscape of Rome, and a favorite with artists, who use its massive head in their Italian scenes as a foil to the limpid azure of the sky. Pliny describes the great eruption of Vesurius in A. D. 79 and compares the form of the stone pine to the mass of smoke which arose from the volcano. Just as the mingled steam and dust arose from the crater in a vertical column and then spread latera!ly on all sicles, so does the stone pine rise unbranched to a considerable height and then send out its branches in a more or less flat mass at the summit.

In Pliny's time the nuts of the stone pine were preserved in honey, and are now commonly used as food. On the islands in the sea of Marmora, where the tree is common, the cones are exposed to fire to make them open and drop out their seals, which are known in Turkish as "fistils." The French call the seed "pignons." It is from the bony shell in which the seed is enclosed that the tree derives its name.

The stone pine has a trunk covered with rugged, deep fissured, thick red-gray bark. It forks at a short distance from the ground and sends out massive, spreading branches of great length which form a flat and round topped crown. The shiny green needles, which are quite long, together with the unique umbrella-shaped crown afford a valuable aid to landscape planting. Excellent specimens are to be seen in the Capitol Park at Sacramento. In its native land the stone pine attains a height of about seventy-five feet, but in this state the finest specimens do not exceed fifty feet in height. It is modcrately long lived and is hardy in regions where there are no heavy frosts.

\section{AUSTRIAN PINE}

The Austrian pine (Pinus laricio austriaca) is a robust hardy, spreading tree with stout, blunt branches and rich glossy, dark-green foliage. It is a variety of the Corsican pine which is a native of southern Europe and which was adopted in 1788 for masts for the French navy. 


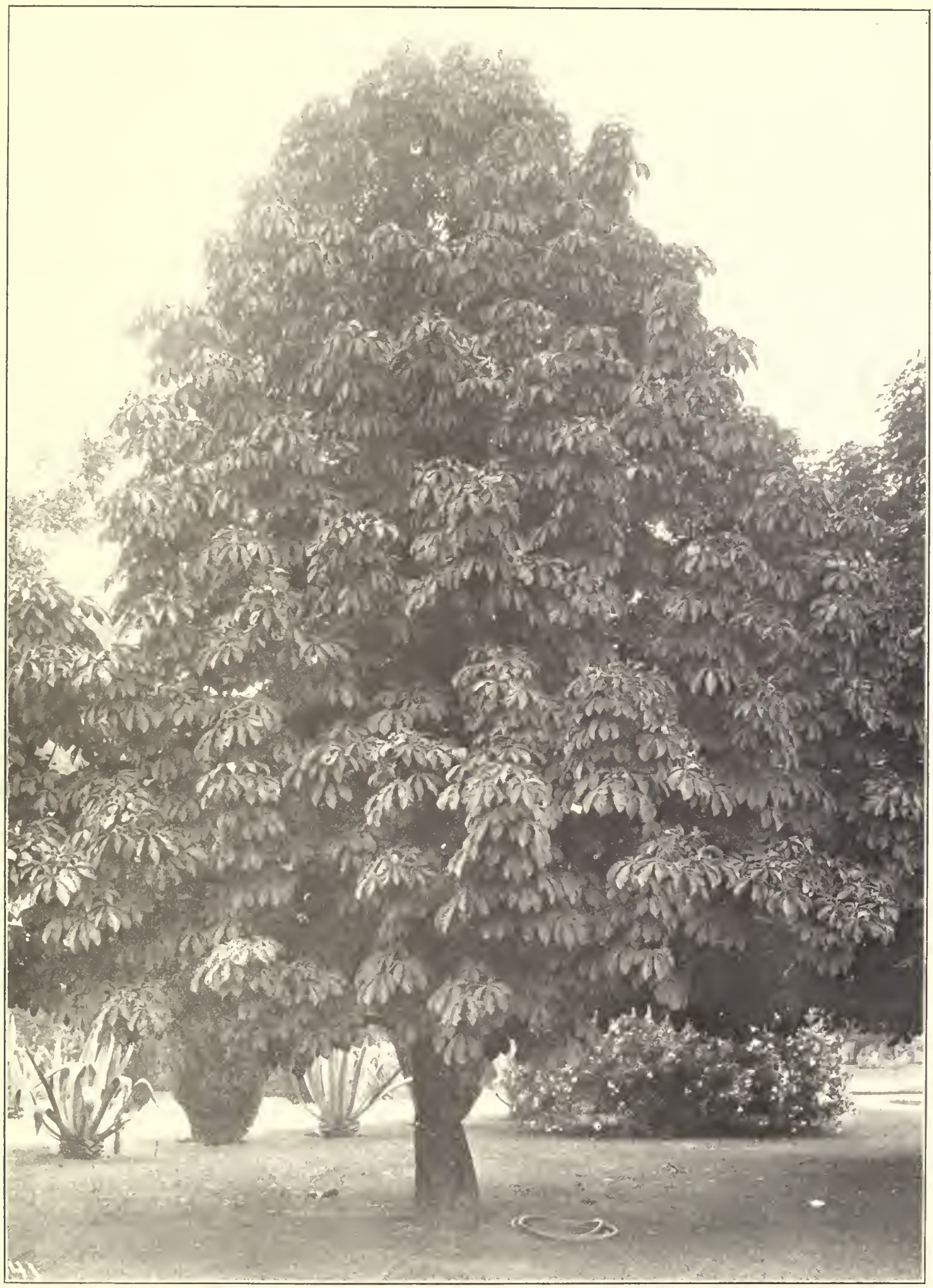

Plate 19. EUROPEAN BUCKEYE. Sacramento.

A handsome flowęring tree with palmate leaves and large leaflets. The flowers are borne in erect panicles. 


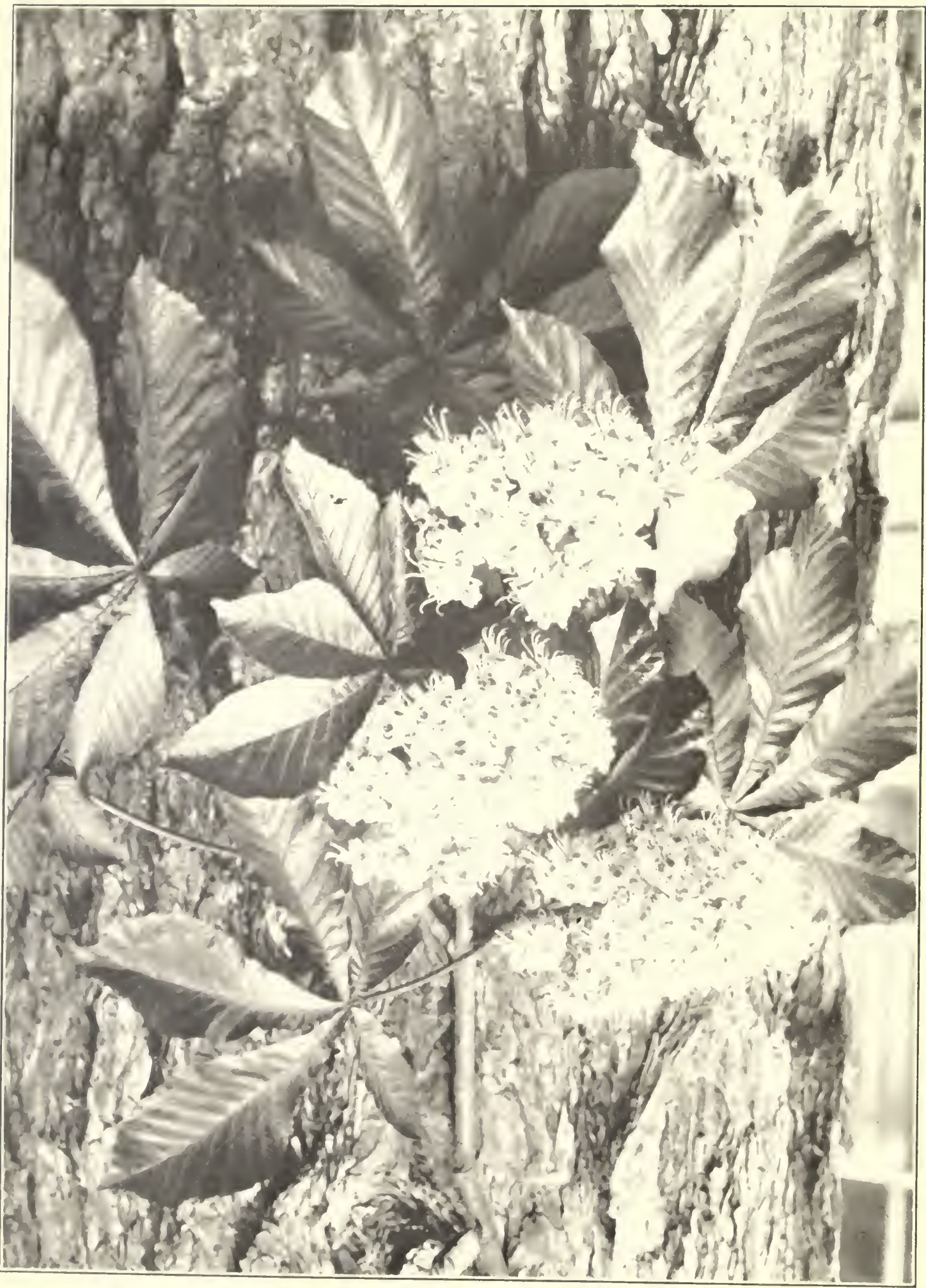


In the Austrian forests this tree reaches a height of eighty to 120 feet and a diameter of three feet. It grows rapidly and well adapts itself to a variety of soils. On account of its dense foliage it is suitable for backgrounds in landscape architecture. It has a long tap root which makes it wind firm and this quality together with its compact foliage makes it desirable for windbreaks. It is also well adapted for planting in cities,..since it is highly resistant to smoke.

\section{MONTEREY PINE}

The Monterey pine (Pinus radiata) is a native of California where it occurs in patches for a distance of 130 miles along the coast south of San Francisco Bay. It reaches its best development near Monterey, where the trees average forty to sixty feet high and one to two feet in diameter. Near the sea the trees lose their upright character and are distorted by the wind into many fantastic shapes. Monterey pine is not cut into lumber these days because of the knottiness of the wood, but the early Spaniards used it somewhat for boat building eighty years ago.

From early days this tree has been extensively planted for ornamental purposes and windbreaks, not only in California but in England and Australia where it makes a remarkable growth. It has a very symmetrical, narrow and round topped crown, and rich green leaves beautifully arranged in clumps on the branches. The growing season is practically continuous. At Berkeley trees attain a height of sixty to ninety feet in thirty years.

The Monterey pine is a comparatively short-lived species and begins to show signs of old age under cultivation at the end of thirty-five or forty years. It will not thrive on wet soils, preferring the slopes, bluffs, ridges and the well drained soils of the coast. It thrives best when the annual rainfall averages about seventeen inches.

For a rapid growth conifer, this species is unexcelled. It is useful for soil protection in semiarid regions, and serves well as a windbreak tree, besides being good for fuel. Its short life and susceptibility to insects and fungous diseases, however, are disadvantages which often cause other species to be chosen.

\section{TORREY PINE}

Torrey pine (Pinus torreyana) occurs naturally only in a small area on the California coast at Del Mar near San Diego and on Santa Rosa Island. It 
was liscosered in 1850 and named in honor of Professor John Torrey of Columbia College, a student of western plants in California before the days of the overland railroad. The city of San Diego has included the little group of these rare trees at Del Mar in a city park in orler that they may be carefully protected against lespoliation.

In its native state, the Torrey pine is a short stocky tree about fort! fect high and a foot in diameter. In situations cxposed to strong sea winds it is semiprostrate with its crown sprawling to lecward. Under the influence of cultivation, it develops a totally different habit and is symmetrical with regular whorls of branches. It grows rapidly and with its foliage in heav! tufts on the ends of the branchlets makes an attractive tree. It is planted as an ornamental, particularly in southern California, with much success.

\section{BIG-CONE PINE}

The big-cone pine (Pinus coulteri) was first collected by Dr. Thomas Coulter in 1831, who found it on the mountains of Santa Lucia near the mission of San Antonio, in latitude 36 degrees, within sight of the sea and at an elevation of from 3000 to 4000 feet above its level. This pine, which has the largest cone borne by any pine, closely resembles the western yellow pine in habit except that the foliage is pale or yellowish green as contrasted with the bright green masses of yellow pine leaves.

It reaches a height of ninety feet in its native habitat in the southern coast mountains of California with a trunk sometimes four feet in cliameter. It is most ahundant on the San Bernardino and San Jacinto ranges at elevations of about 5000 feet. The seeds were formerly gathered and eaten by the Indians of southern California.

Big-cone pine is planted somewhat as an ornamental on account of its striking foliage and cones, but its chief importance is for a cover on arid slopes where other species will not grow.

\section{CANARY ISLAND PINE}

The Canary Island pine (Pinus canariensis), or blue pine as it is often called, is a native of the Canary lslands. It does very well under cultivation. especially in southern California, where it is said to grow as fast, if not faster. than Monterey pine, a native tree of remarkable growth. The long pendent needles of a glaucous blue color give the tree a distinctive appearance. The 


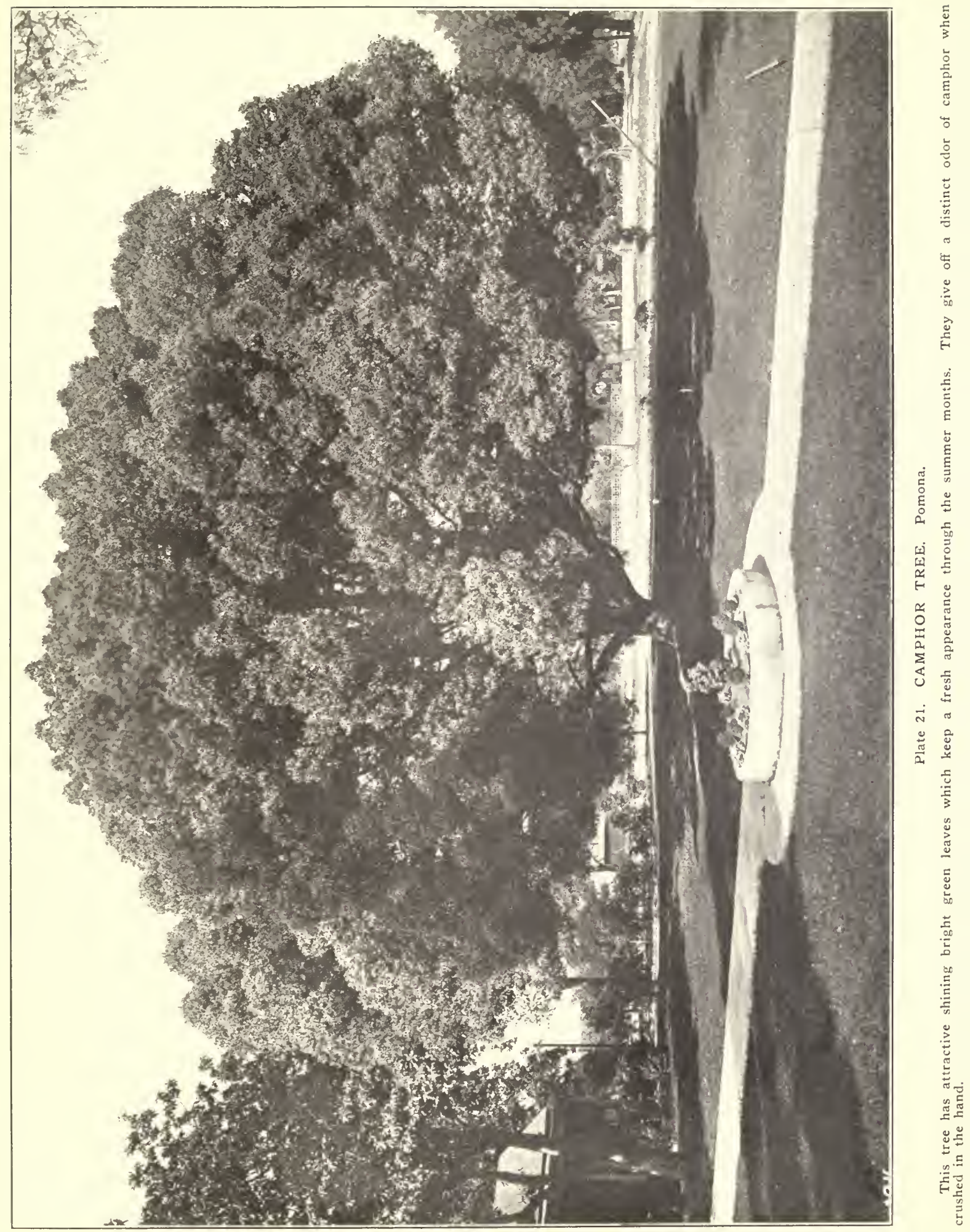




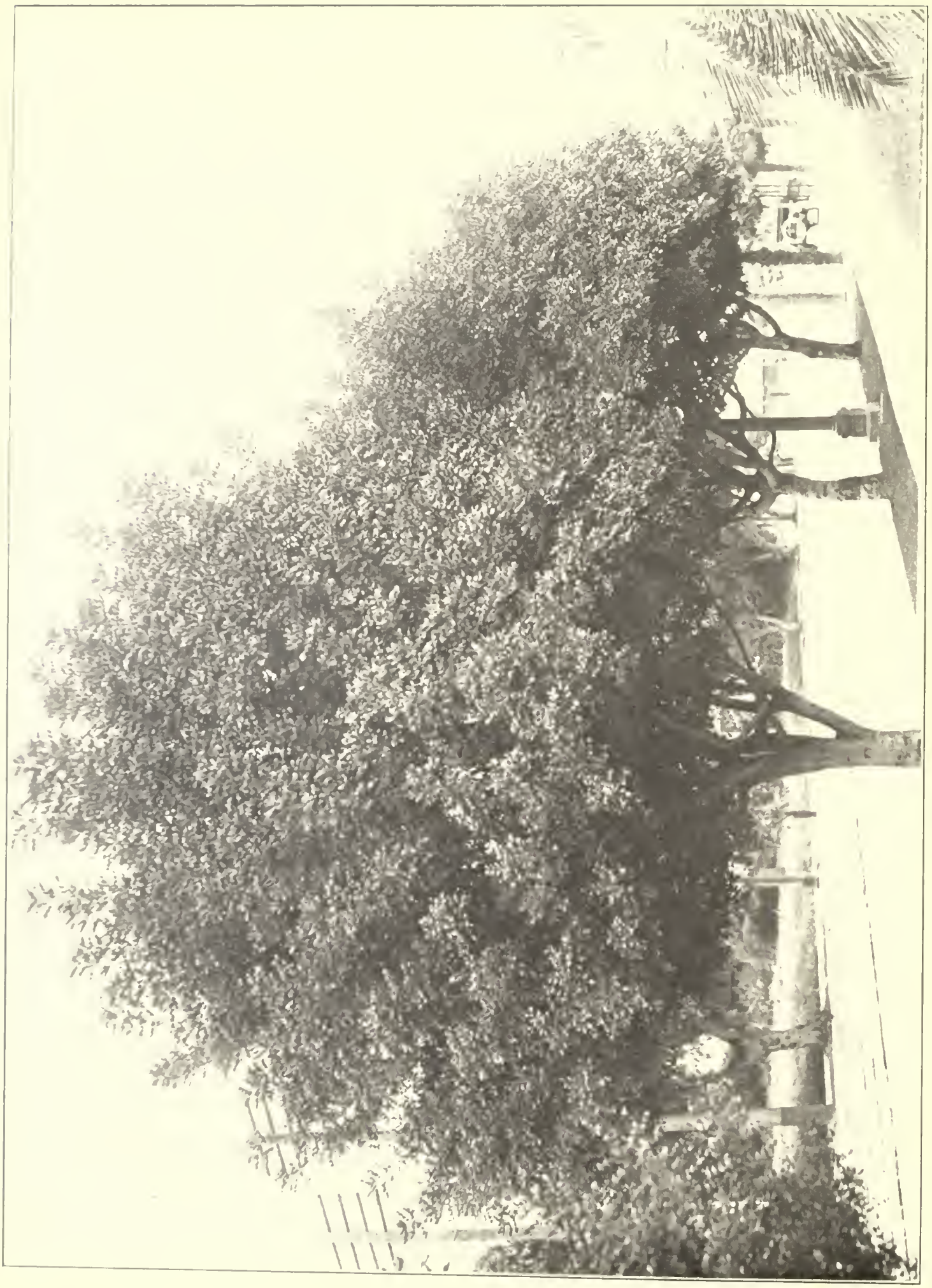


branches are slender, and form, at maturity, a broad, round-topped head although the young trees have the pyramidal form characteristic of conifers. Canary Island pine stands drought well, and has the peculiarity, possessed by only a few of the conifers, of sprouting from the stump when cut down.

\section{ALEPPO PINE}

The Aleppo pine (Pinus halepensis) is, a native of the Mediterranean region which thrives well on arid situations in California, where it is particularly adaptable for seaside planting. It is a tree of rapid growth and spreading habit, the younger branches often assuming a peculiar twisted appearance. The needles are short, grayish in color, and occur in tufts on the ends of the branchlets. The tree reaches a height of about sixty feet and has an open appearance which does not lead to its choice as an ornamental where more attractive foliage trees will flourish. Its chief merit is its ability to flourish under adverse soil and atmospheric conditions.

\section{SPRUCES}

The spruces (Picea) are often confused with the firs (Abies), from which they can easily be distinguished by their needles, which are borne on short leaf stalks instead of directly on the branches, as in the case with firs. The little stalks that remain after the needles fall give the branches a rough appearance. The cones are pendent instead of erect and do not lose their scales as do those of the firs.

The spruces are naturally tall trees of symmetrical habit, with spreading whorled branches densely clothed with sharp-pointed, four-sided needles. There are at least eighteen species found in the northern hemisphere, nearly all of them being under cultivation. Spruce is extensively planted as a forest tree by European foresters to serve as a nurse for the young oaks or elms that are planted beneath its dense foliage.

The spruces in the Vosges Mountains of Europe produce a resin which is of considerable value. It oozes from cracks in the bark of the trees and when treated forms the medicinal Burgundy pitch. The generic term Picea was derived from the Latin word meaning pitch, and it was the spruce that provided the pix liquiida, the boiling liquid pitch that was employed for purposes of torture in the days of the early Roman Empire. 
Weighted with loads of snow or tossed by boisterous winds, the spruce, as seen in Alpine landscapes, is attractive to artists. " It is, "says Sir Thomas Lauder, "the great tree of the Alps, and is so mentally associated with the grandeur of Swiss scenery that the sight of it never fails to touch chords in our bosom which awaken the most pleasing recollections. What can he more truly sublime than to behold, opposed to the intensely hlue ether, the glazed white summits of Mount Blanc, or the Jungfrau, rising above the interminable forests of spruces which clothe the hases of the mountains?"

The spruce tree serves for more than beauty since it is from its wood that the frontal part of the violins of Brescian and Cremonese fame were constructed. It was from the wood of the spruce, in preference to all other woods, that the violins of Antonius Stradivarius were made, and which now fetch such fabulous prices. Choice specimens of spruce wood were selected by the old fiddle designers, and we can readily picture them exploring the mountainsides to find the trees which would best furnish them with the resonant wood they needed for

\footnotetext{
"That small, sweet thing

Devised in love and fashioned cunningly

Of wood and strings."
}

\section{NORWAY SPRUCE}

Norway spruce (Picea excelsa) is a native of northern Europe, where it was the original Christmas tree. It has a graceful, flowing outline of light green foliage. The growth is rapid and the branches compact which well adapts it for windbreaks or shelters. Like many of the spruces and firs, it is apt to lose its beauty when it reaches an age of fifty years or more, and become thin and ragged in the top. Several varieties of this tree have been developed by nurserymen, one of the most picturesque being a weeping variety with irregular drooping branches.

\section{COLORADO BLUE SPRUCE}

The Colorado blue spruce (Picea pungens) has a striking appearance clue to the bluish tinge of its foliage. Koster, a nurseryman, developed a variety with extremely silvery foliage by grafting on Norway spruce stock. This spruce is highly ornamental and is commonly used to add emphasis to a lawn. Care should he taken, however, not to make this emphasis too bold. As a 


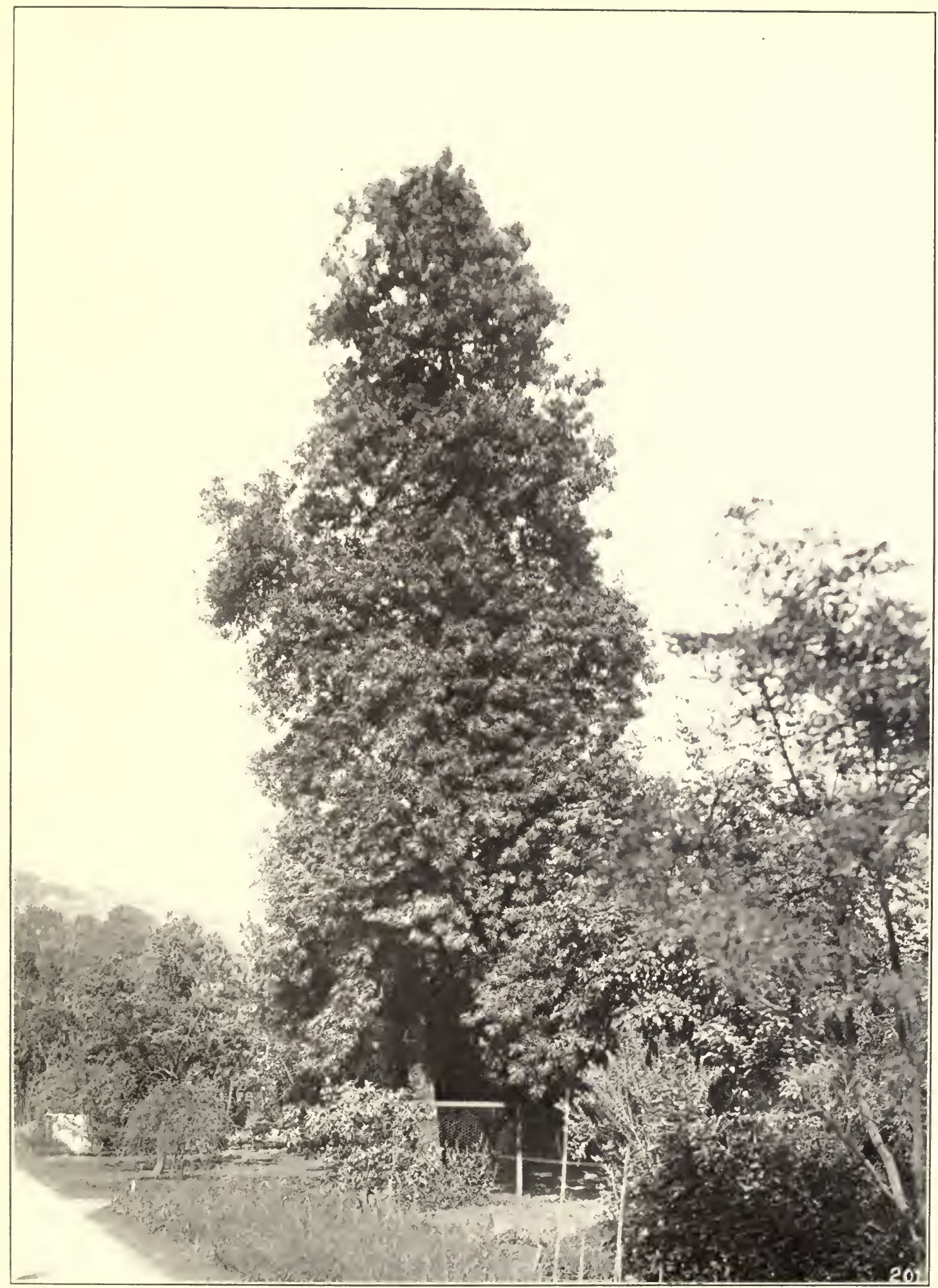

Plate 23. ISLAND IRONWOOD. Berkeley.

Native oniv to the islands off the coast of Southern California. It is a rare species which is worthy of trial as a street tree because of its erect habit of growth, moderate spread and narrow crown, 


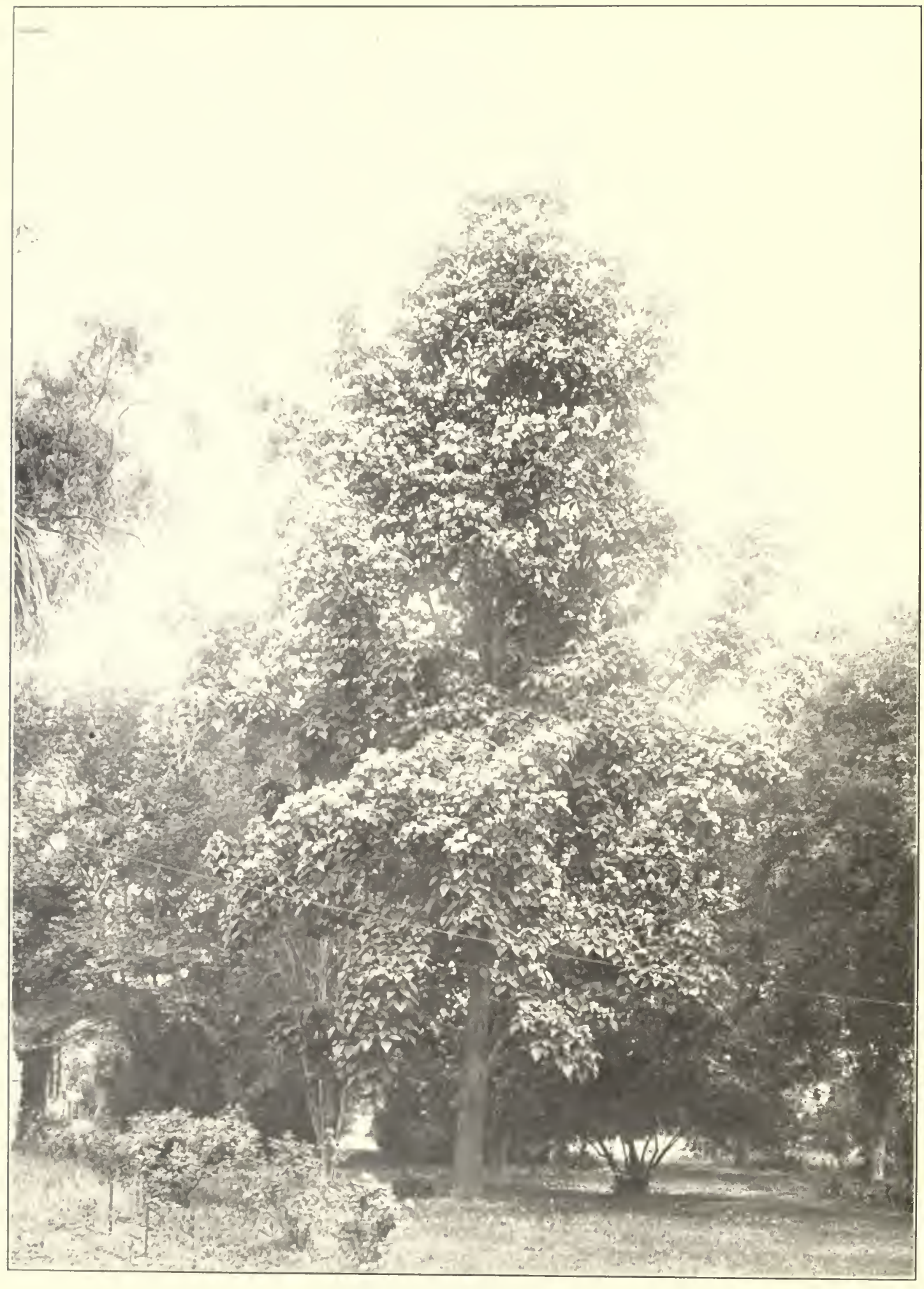

Plate 24. CATALPA. Fresno.

A tree that is noticeable for its large, heart-shaped leaves and panicles of white, fragrant flowers. 


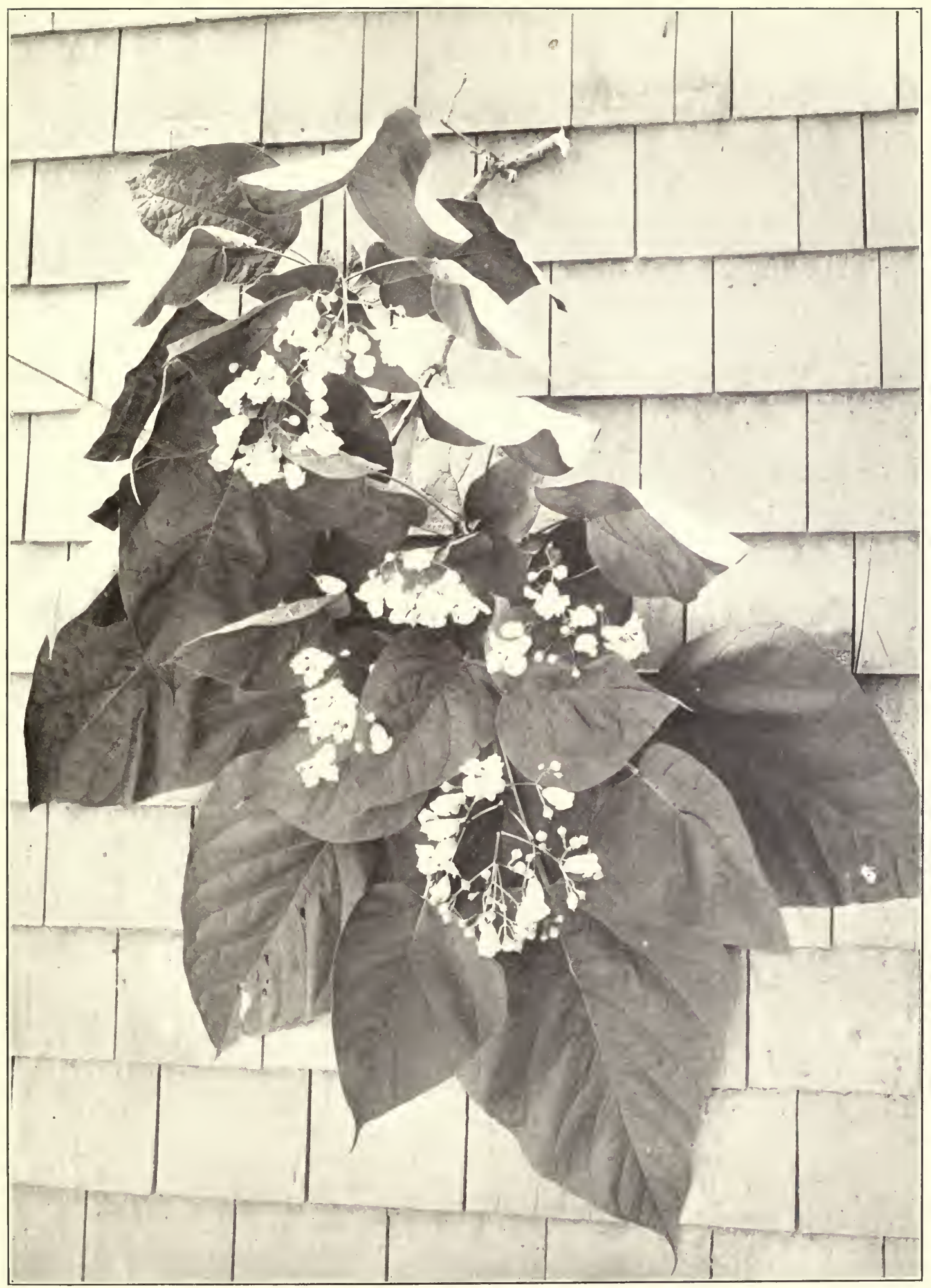

Plate 25. CATALPA BLOSSOMS. Fresno.

The tubular bignonia-like flowers nestle among the large, heart-shaped leaves. 


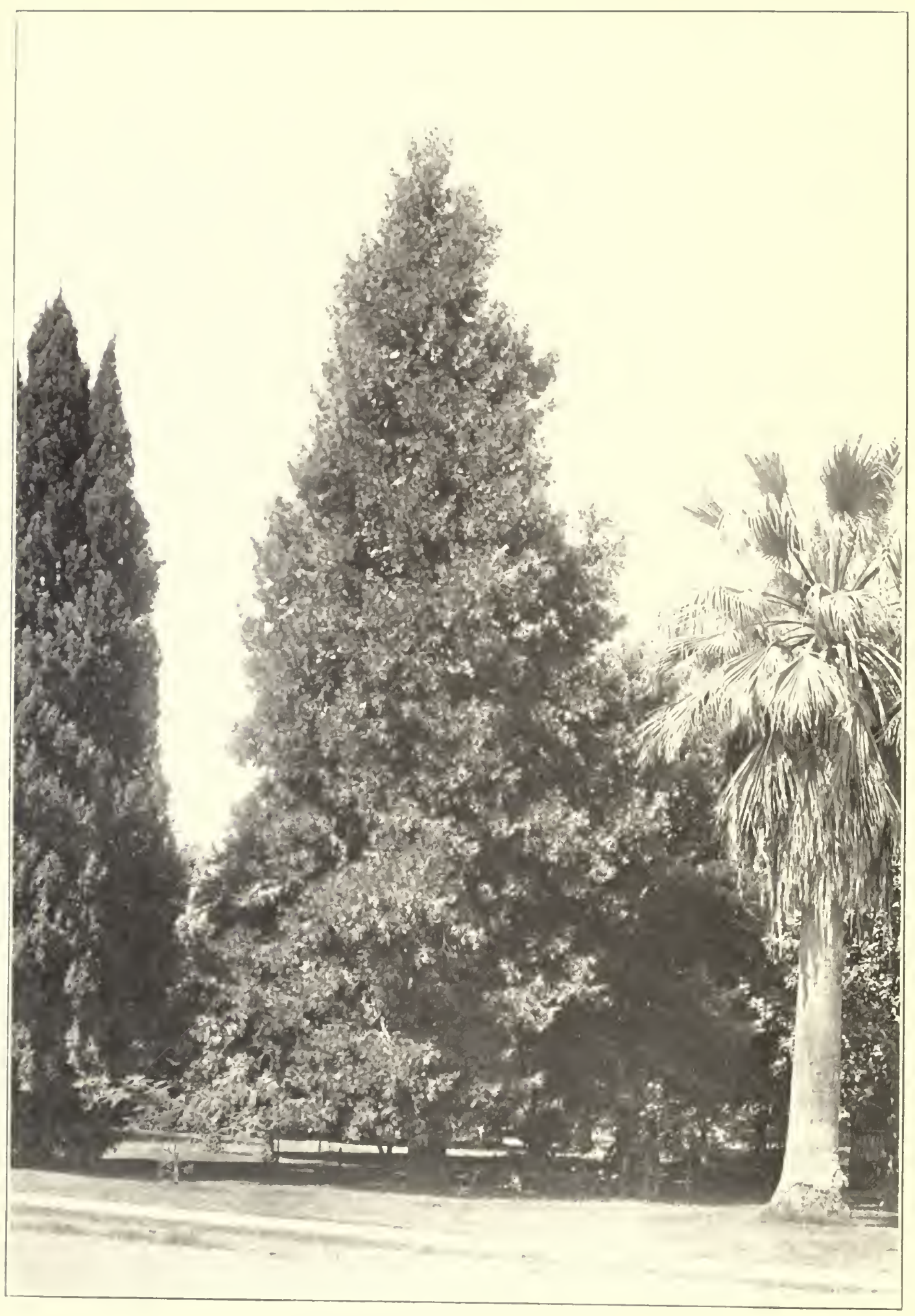

Plate 26. INCENSE CEDAR. Visalia.

"Its brighe brown shafts and warm masics of plumy foliage make a strikin" feature of the landscape." 
rule, the best effects are obtained by associating it with evergreens of a less spectacular color. When this is done, its striking characteristics will not appear gaudy, but will harmonize with the other trees in the background in a pleasing manner.

\section{ORIENTAL SPRUCE}

The oriental spruce (Picea orientalis) from Asia is one of the most delicate and graceful of all spruces. It has about the same color as Norway spruce, but with more slender branches and shorter leaves. It grows very slowly and is well adapted for small grounds.

\section{SITKA SPRUCE}

Sitka spruce (Picea sitchensis) also known as tideland spruce, which is of so great importance for aeroplane material because of its strength, elasticity, straight grain and comparative freedom from hidden defects, was extensively logged during the recent war by the government through "spruce regiments." It reaches its best development in Oregon and Washington, but grows to some extent along the coast of northern California.

Sitka spruce makes a striking ornamental tree with its dense rich blue or sage foliage. From a distance some branches appear greenish, others silvery, the variation in color forming beautiful contrasts. It attains a height of 100 to 150 feet under cultivation, although a height of 200 feet is not uncommon in its native habitat.

\section{YEWS}

Yew (Taxus) reflects many aspects of early religious and social life. Virgil knew its habits when he wrote "The vine loves the hills, the yew tree, the north wind and the cold."

The pagan people of antiquity in south Europe held the cypress in reverence, and the yew was so regarded by the northern tribes. It was their custom to bury their dead around yew trees, and place yew branches beneath the body, in the grave, since the long life of the tree was regarded by them as a symbol of immortality. Yew trees are still very common in the churchyards of England. They have been described as sable, sombre, and gloomy in many a book of prose and poetry.

"Like the black and melancholy yew tree,

Dost think to root thyself in dead men's graves,

And yet to prosper?" 
Another reason for its presence in churchyards may be due to the fact that its wond was used for crosshows, the chief weapon in the early wars. The Greek word meaning bow was evolved from another Greek word meaning vew, because they made bow's and arrows of it.

The battles of Crecy and Poictiers were won with yew bow's, and Edward II enacted that every. Englishman should have a bow of his own height. Later the supply of yew became scarce because of the demands made on it for how's, and all the how'ers were ordered to make four bow's of witch-hazel, ash. or ehn to erery one of vew: in order that the supply of this valued wood might be preserved. This is said to be one of the earliest forest regulations in England.

The genus Taxus includes six species of small trees and shrubs which occur wer a wide range in the northern hemisphere. Their rich, lark. glossy foliage gives them a sombre hue which is a decided contrast to other trees. In many a landscape the yel strikes a deep, solemn note which makes the other trees look all the brighter for its presence. The red berries which are borne by the yew instead of cones add to its beauty. The berries are on the under side of the leaf sprays where they make an attractive setting. The yew is slow of growth, but grow's for many years, and will live for centuries. There are three species of American yew, two of which are found in the Eastern States and one on the Pacific Coast. The western species is the largest, reaching a height of twenty to thirty feet, and a diameter of from six to twelve inches.

\section{THE ENGLISH YEIV}

The English yew (Taxus baccata) gives a fine scenic effect in the spring with its dark foliage standing out in contrast to the light green coloring of its surroundings.

"Where the distinguished yew is ever seen,

Unchanged his branch, and permanent his green."

The bushy head of this yew can be trimmed into any form and trees are commonly seen that have been converted into such unnatural shapes such as peacocks, pyramids, and teapots. No matter how much the yew is clipped, there are always buds in the angles between the narrow leaves and the stems that will give rise to new growth and fill up gaps. 


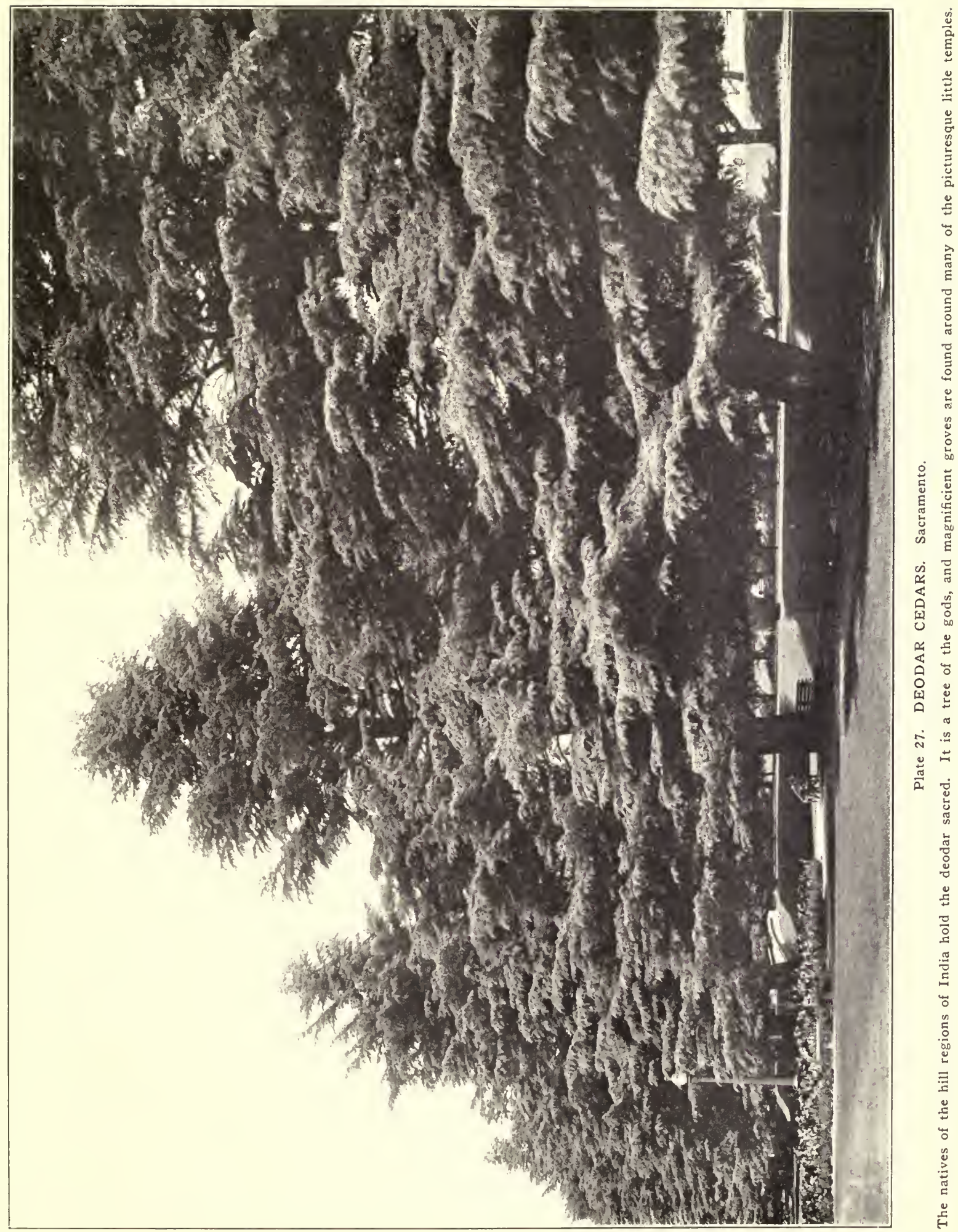




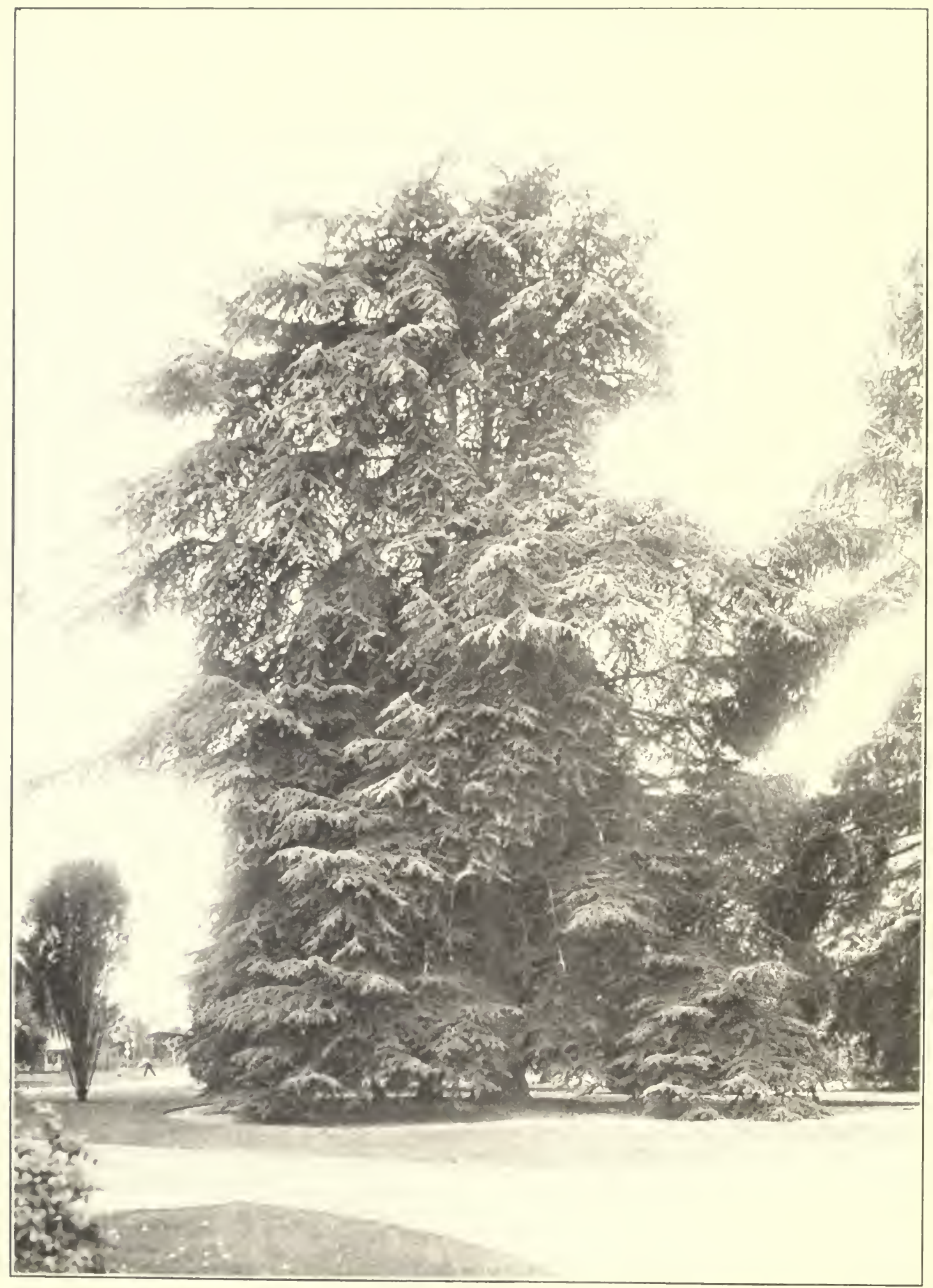

Plate 28. LEBANON CEDAR. Pasadena.

"Behold the Assyrian was a celar in Lebanon with fair branches, and with a shaclowin shroud, ancl of an high stature: and his top was among he hick bours." 
The trunks of old trees are often greatly enlarged by the coalescing of shoots which develop about the base giving them a cathedral-like effect. In Darley Dole Churchyard in England there is a yew formed in this manner. A peculiarity of this coalescing of the main and minor trunks is that the main trunk may eventually die, but the hollow tree will still be nourished by this outer, living shell of younger shoots.

\section{THE IRISH YEW}

The Irish yew (Taxus baccata fastigiata) was produced from a freak of the English yew, and was first found growing wild more than one hundred years ago in the mountains of County Fermanagh in Ireland. Cuttings from this tree gave us all. the Irish yews of today. They have an upright habit of growth, resembling a bundle of closely packed branches. The foliage is of the darkest hue, and the whole tree appears like a deep green column. I rish yews are well adapted for formal effects and avenue planting. They form one of the most striking approaches to the State Capitol at Sacramento.

\section{THE WESTERN YEW}

The western yew (Taxus brevifolia) is an American species which is widely distributed along the coast of California and in the mountains as far south as the southern Sierras. It seldom exceeds forty feet in height and one to one and one-half feet in diameter, its best development being in moist, cool canyons. The wood is very hard, durable and close-grained, and was formerly used by the Indians for paddles, spear handles and bows. This yew, which resembles the English yew, is occasionally cultivated in gardens. 


\section{BROAD-LEAF TREES}

Broad-leaf trees are hest adapted for street and highway planting due to the shade afforded by their broad crowns during the heat of summer. As a rule teciduous broad-leafs are more desirable than those which keep their leaves the vear round since they (o) not prevent the drying of roads and streets after the winter storms.

There are comparatively few broal-leafs in the number considered that are suitable for street and highway planting. The foliage is a minor consideration in comparison with other factors such as the adaptahility of the tree to local climatic and soil conditions, and its response to care. Fior this reason much consideration must he given to selecting suitable species for roadside and street planting. The tree chosen should have a desirable habit of growth, capable of adapting itself to soil conditions and be a long-lived variety. that improves rather than deteriorates with age.

The ornamental value of broad-leaf trees lies in their variety of foliage and form. The changeableness of color in the foliage of the deciduous broadleafs, the variety of branch systems in their naked winter condition and the awakening of Nature in the early spring are sources of perpetual interest The evergreen broad-leafs, which have the great attraction of remaining green throughout the year, have their place in the consideration of any landscaping plan. N lany of the broad-leafs have flowers which add to their ornamental value.

There is a large variety of broad-leaf ornamental trees, both native and exotic, found in California. Some flourish in temperate climates, and some require subtropical conditions. Some stand drought and alkali, others require good soil and moisture conditions. A good guide for the selection of trees for planting is the class of material found growing in nurseries under local conditions. Trees that might flourish in the coast region may prove entirely unsuited to the hot interior valleys. It is very important to study local conditions before selecting any tree, whether it be broad-leaf or conifer. for planting. 


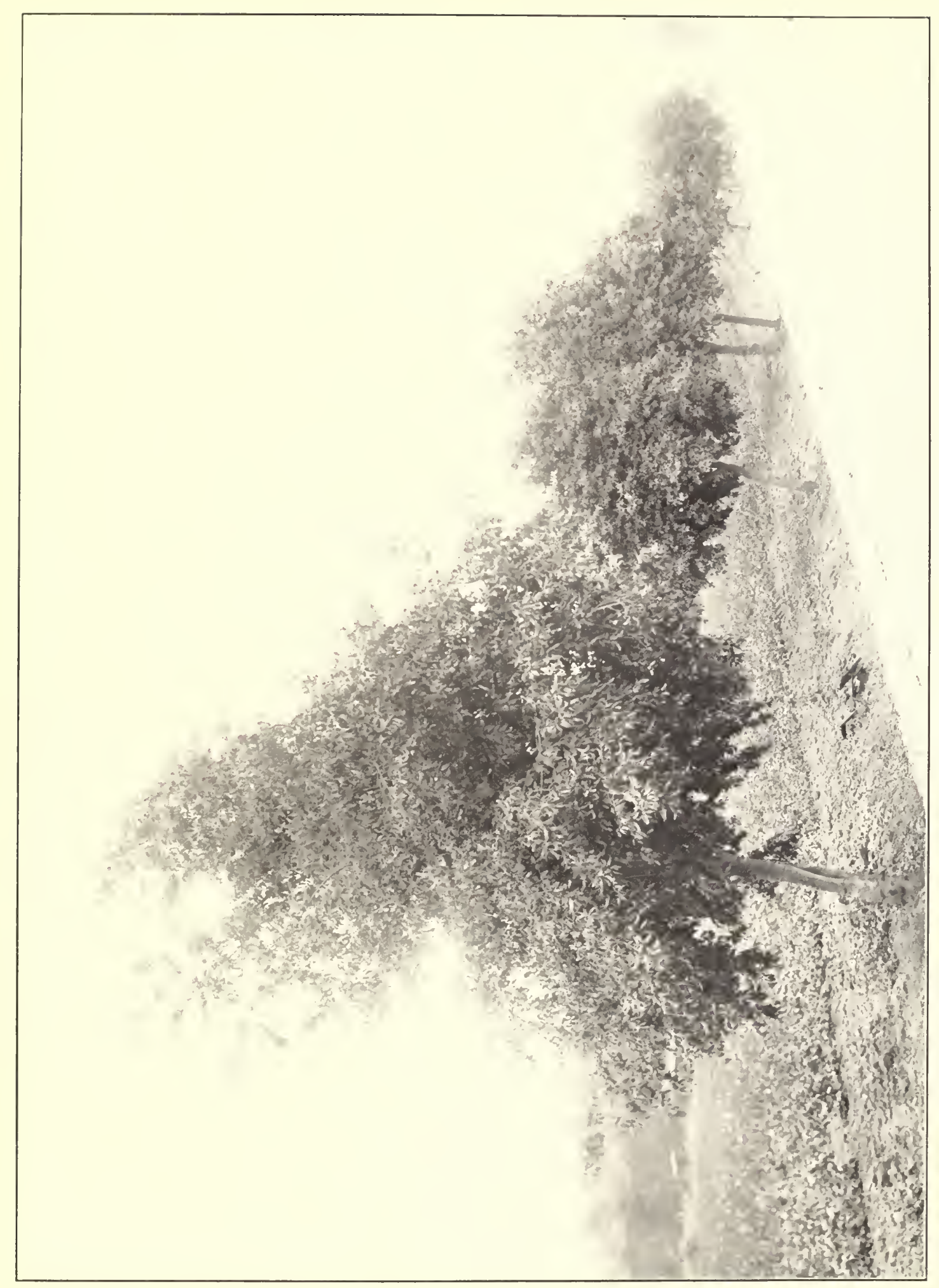




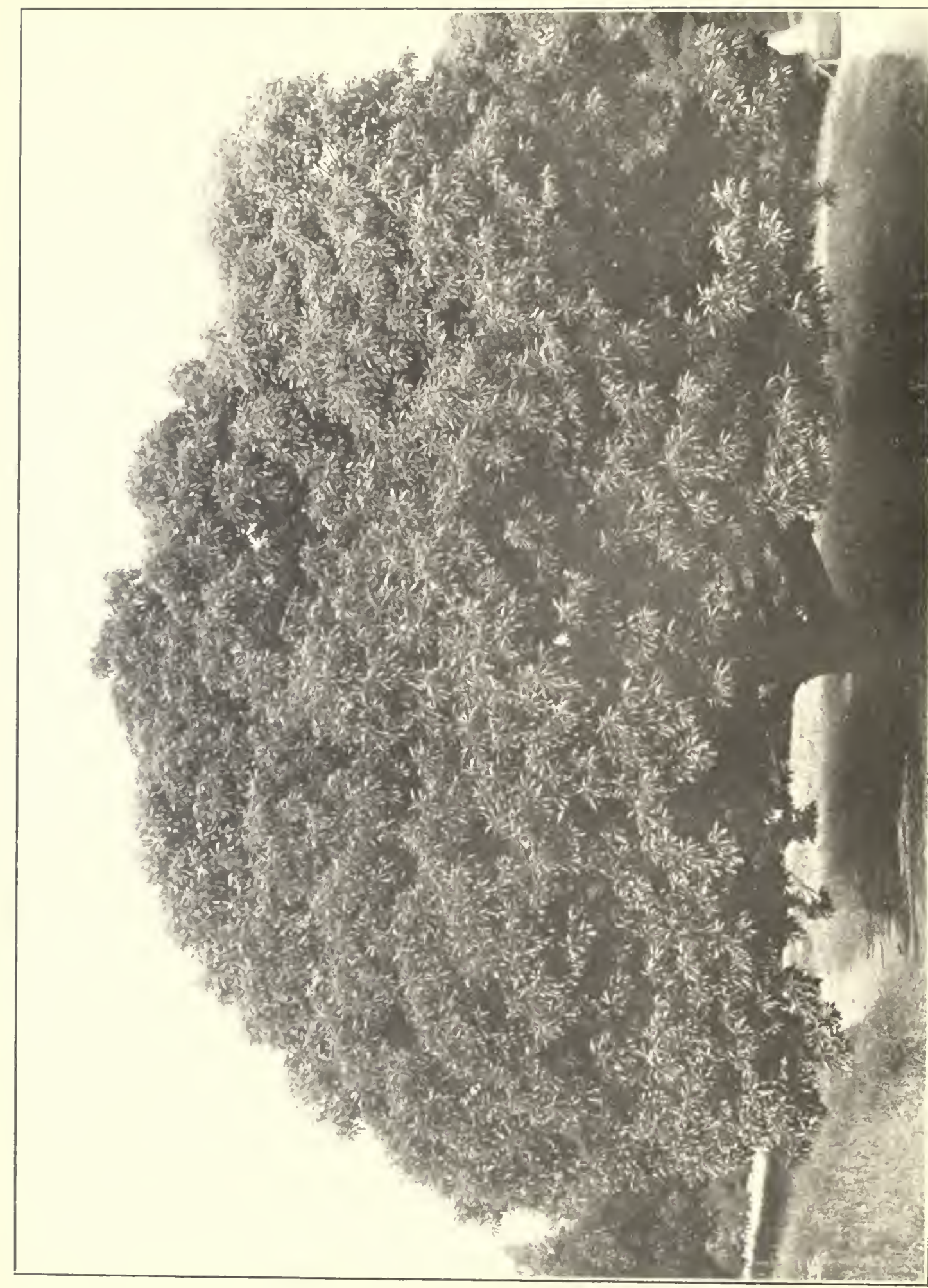




\section{ACACIAS AND FALSE ACACIAS}

The acacias and false acacias belong to the Pulse family, which is characterized by its pod-like fruit and compound leaves composed of small leaflets which form a graceful foliage Most species have spines, and some have striking flowers which give them additional ornamental value.

All members of the Pulse family, which contains over seven thousand species of plants throughout the world, have the power of transforming the nitrogen of the air into a fertilizer that enriches the soil in which they grow. The plants range in size from peas, beans and alfalfa to large trees. All of them are called legumes because of their pods which are of the order of those borne by beans and peas.

The trees in this family embrace four to five hundred species which are mostly small or medium-sized. They are widely distributed in all temperate and tropical regions. Some of the genera have little commercial or ornamental value. Others such as the Acacia, Robinia, Gleditschia and Cercis are widely planted because of their attractive foliage and flowers, and their ability to flourish in poor soils and under arid conditions.

\section{ACACIAS}

The generic term Acacia is derived from a word meaning a point or thorn, and relates to the branches, which are usually armed. It is a very large genus which embraces more than four hundred species dispersed throughout the tropical parts of the earth and in parts of the temperate zone. Ten or twelve species are native to North America of which four are arborescent. The Australian species are the largest and most valuable for timber. Other species yield valuable by-products such as flowers for perfumery, bark for tanning purposes, wood for medicines and dyes, and gum arabic.

The acacias have great historical and symbolic significance inasmuch as the Ark of the Covenant and the Ark of the Tabernacle were made from one species, the Shittim wood of the Bible. On account of its "incorruptible" wood this species was also used by the Egyptians to make coffins for the burial of their kings. The Buddhists and the Hindus regard the wood of the acacia as sacred and burn it on their altars Chinese doctors believe that the acacia is identified with the eye and prescribe its use to clear the eyesight. 
Many species of acacia are cultivated for their graceful foliage and handsome fragrant flowers. Over one hundred species have been introduced into California, nearly all of them heing hardy even when grown in poor soil. They are rapid growers, cases being known where trees have grown to a height of twenty-five feet in six years. At thirty years most of the trees reach maturity and thereafter hegin to deteriorate. This gives them a ragged appearance which is further intensified by the breaking of the hrittle wood of the limbs by the wind.

\section{Blackwood Acacia}

The blackwood acacia (Acacia melanoxylon) is one of the most common of the acacias particularly in the southern part of California. It is an erect, pyramidal grower and forms a well-shaped head. The leaves are large and ohlong and tend to give the tree a funereal aspect which is objectionable when the trees are planted too close together. When young the tree has both blade and feather leaves. The blossonns, which are a very light yellow, appear in heads.

This tree is well adapted for street and highway planting on account of its rapid growth and symmetrical form. It needs little attention and will stand considerable abuse. It will stand more water than the other acacias and will do well in parkings where there is grass. The tree needs ample room for development and when planted should be headed high to keep it from becoming too dense

\section{Green Wattle}

Green wattle (Acacia decurrens) has pinnately compound foliage, and a wealth of pale yellow blossons early in the spring. It is a good park and avenue tree, but must be given attention else its habit of growth will be bad. Care should he taken to select erect specimens and prune them during the first few years following planting. A disadvantage of the tree is that it casts little shade at maturity due to its open head.

\section{Bailey's Acacia}

Bailey's acacia (Acacia baileyana) is a small tree rarely exceeding thirty feet in height which is chiefly planted for ornamental purposes. The silvery fern-like foliage, blending with its beautiful golden flowers, makes it the most 


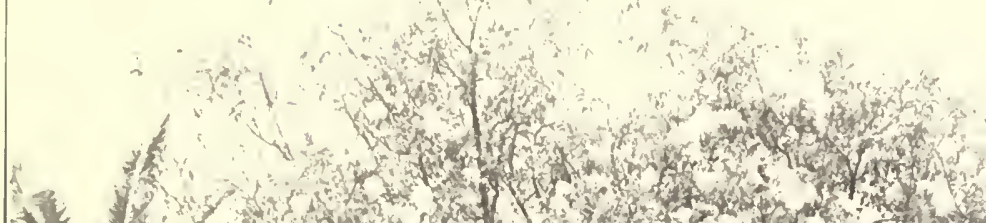

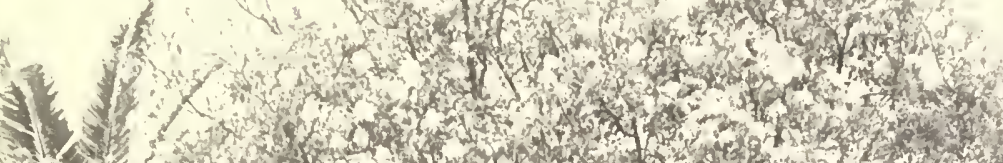

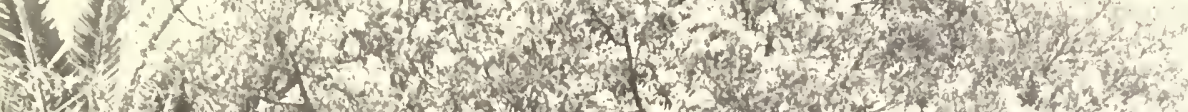

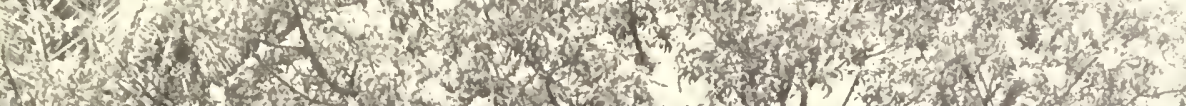

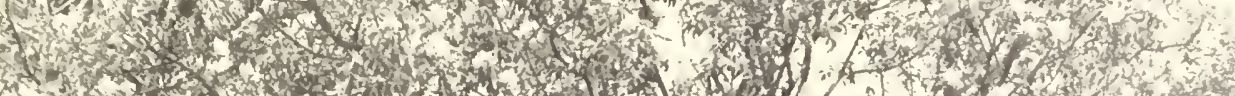

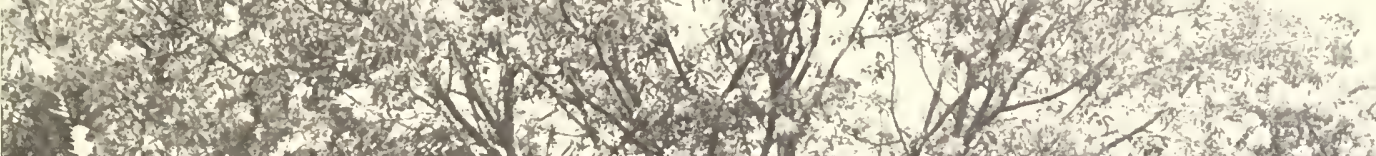

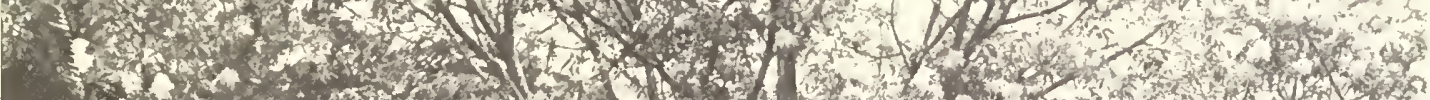

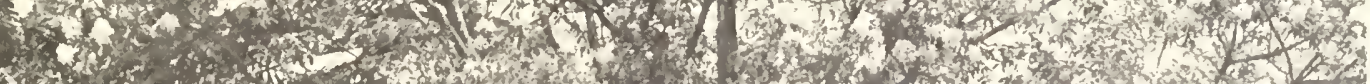

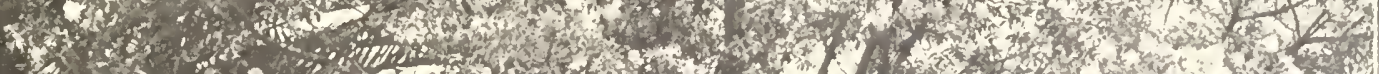

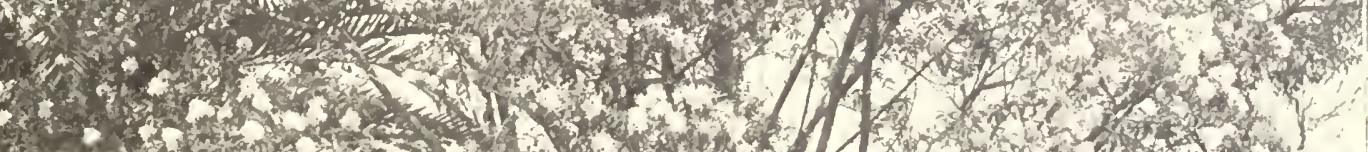

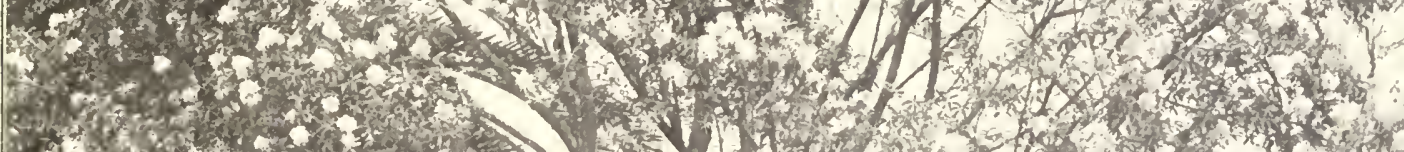

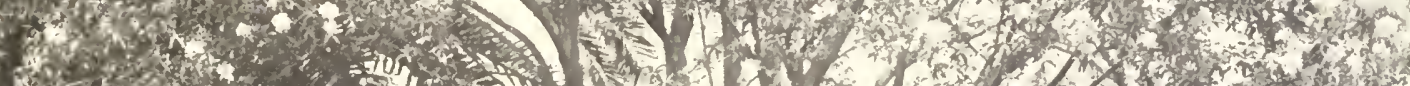

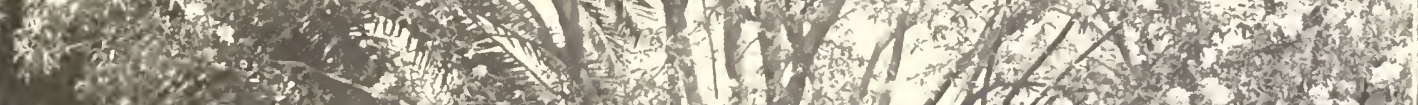

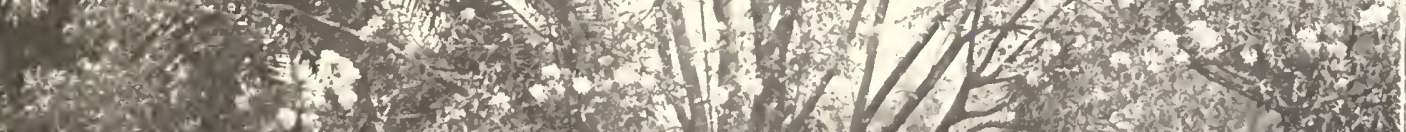

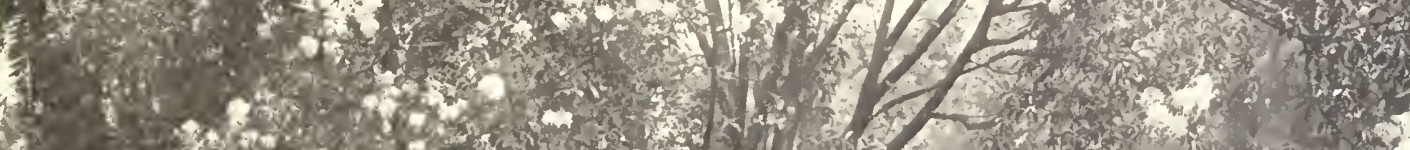

3

ì

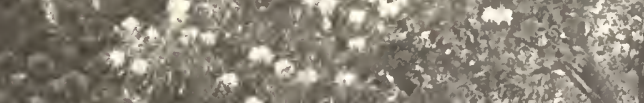

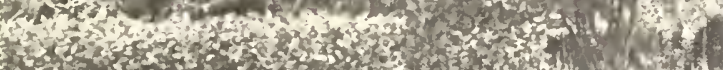

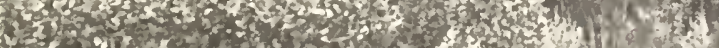

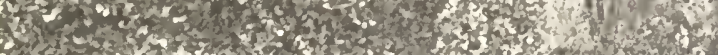

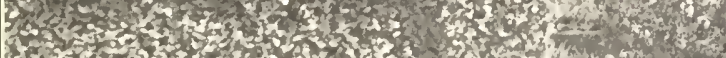

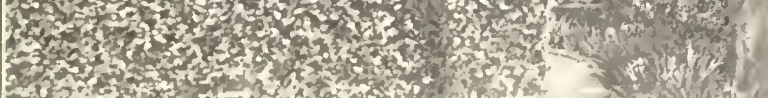

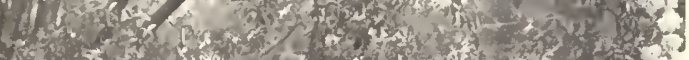
4. 2 .

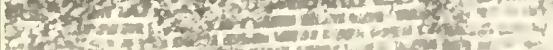

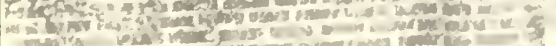

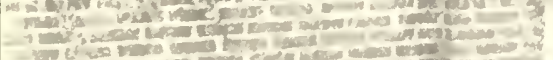

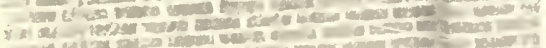
Cor

Plate 31. CAPE CHESTNUT, Los Angeles.

A rare tree. from the Cape of Good Hope, which has large, beautuful blossoms. The tree shown in the illustration was planted about 1893 by the daughter of General Fremont. 


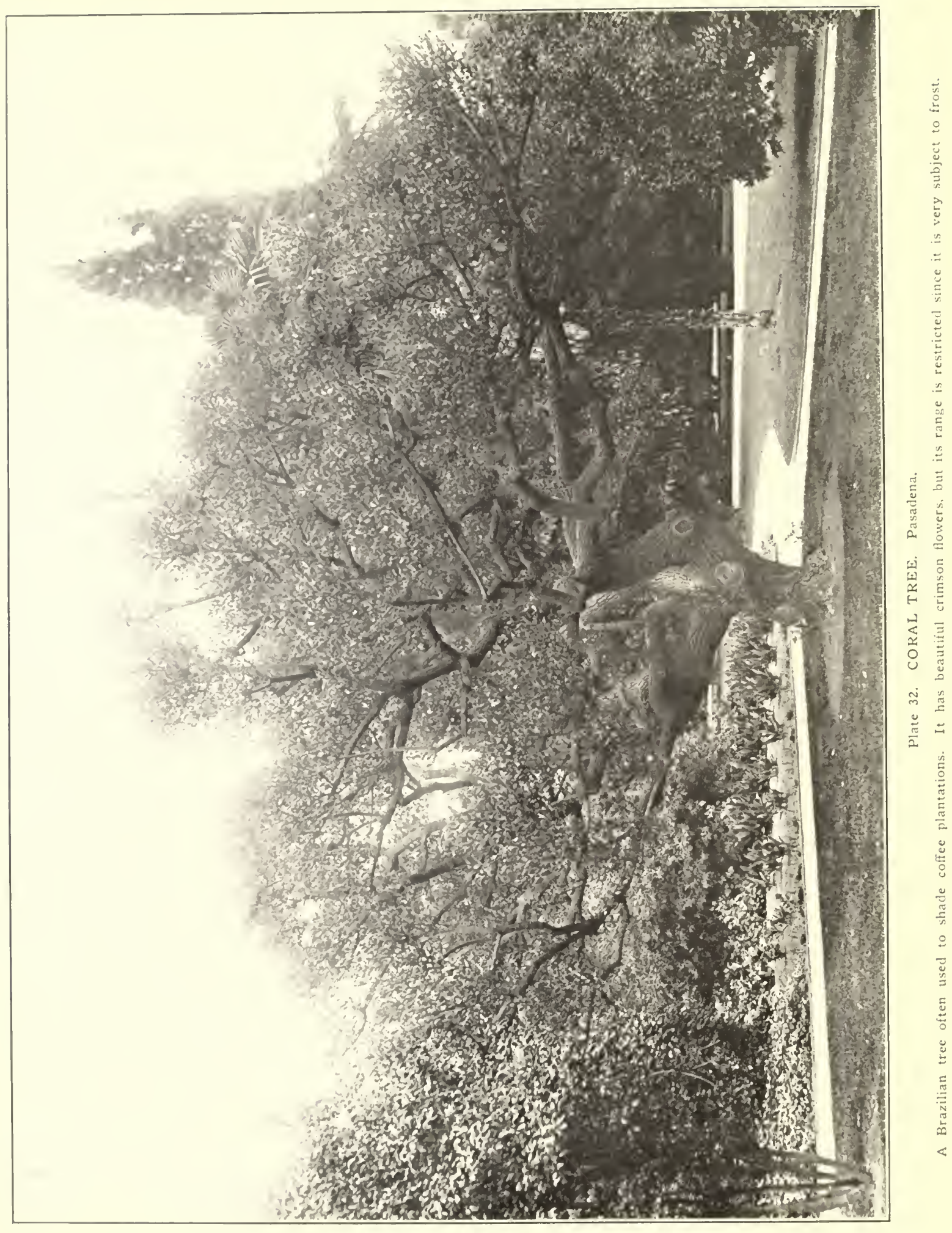


attractive of the acacias. The growth is rapid, but unfortunately the tree is short-lived and begins to decline when many other trees are reaching the full glory of their maturity.

\section{ALBIZZIAS}

The albizzias were named after Albizzi, an Italian naturalist. They are closely allied to the acacias and are grown chiefly for their handsome foliage and attractive flowers. There are about twenty-five species in the tropical and subtropical regions of Asia, Africa, and Australia.

One of the most attractive species is the Constantinople acacia (Albizzia julibrissin). It has a low and spreading growth with very finely divided feathery leaves. The flowers, which are borne profusely in the summer, occur in delicate pink heads which are crowded on the ends of the branches. This tree reaches a height of about forty feet and is hardy especially in the Sacramento and San Joaquin valleys on good, well-drained soil.

This is one of the favorite trees of John McLaren, Superintendent of Golden Gate Park, San Francisco, who commends it as follows:

"The full effect of the beauty of this most interesting tree is had when it is planted on a rising ground, against a background of pine or other dark foliage, in the full sunlight in which it seems to delight."

\section{BLACK LOCUST}

The black locust (Robinia pseudacacia) is a native tree of the eastern part of the United States which is known in Europe as the false acacia because of its resemblance to the true acacia. The generic name is in honor of the Robin brothers, who were arborists for one of the early French kings. It was introduced into France by Jean Robin in about I600 and became a favorite because of its beautiful flowers and foliage. In i664, Evelyn, an Englishman, in his Sylva, recommends black locust as "deserving a place among our avenue trees, adorning our walks with its exotic leaves and sweet flowers; very hardy against the pinching winter. It thrives well in His Majesty's new plantation in St. James' Park."

In the eighteenth century the value of the black locust for timber and as a soil improver due to the nitrogenous nodules on its roots became recognized. It was planted on an enormous scale in England and the prophesy was made that it was destined to speedily replace most of the hardwood trees in 
cultivation, and would become more common in time than the oak. About this time, the French also began to plant the black locust on an extensive scale, and it was decreel that Mlay sixth of each year should be consecrated to this tree.

In its native country the black locust reaches a height of eighty to ninety feet and a cliameter of three to four feet. When grown in the open it branches low, and the top is open, rounded and irregular. The leaves are eight to fourteen inches long and consist of small oval leaflets arranged in pairs on the sides of the leaf stem with a single leaflet on the top. The tree is most beautiful when in flower when the pendent white clusters of pea-shaped blossoms are set off by the dark green foliage. The flowers were symbolic to the Indian, who presented them to the lady of his choice as a declaration of his love.

The fruits of the black locust are brown poils which may hang on the tree through the winter. The tree is least attractive at that season since the absence of the leares reveals the open branches and the rough, ridgy bark of the trunk.

The ability to grow in a wide variety of soils and under arid conditions is a strong point in faror of the black locust. Its habit of suckering is its chicf objection, although this propensity varies greatly. In some places it suckers freely while in others practically no suckering takes place. The tree can be casily propagated by cuttings and grow's rapidly, making a dense hard wood, which is valuable for posts. It is the best wood known for tree-nails and was in great demand during the late war for that use in the construction of woolen ships.

Black locust did not supersede all other trees in England as was predicted, but many fine specimens are found there, some of them three or four feet in diameter. It is a common tree in California particularly in old mining camps where it was planted by the pioneers who brought the seed with them across the plains or around Cape Horn. The beauty and fragrance of these trees in the spring now forms the chief attractiveness of many of these old camps, some of which have become practically cleserted.

\section{HONEY LOCUST}

Honey locust (Gleditschia triacanthos), which grows naturally in the Appalachian region and as far west as Kansas and Texas, is planted for orna- 
mental and street purposes because of its handsome, finely divided foliage which resembles that of acacia, its large conspicuous pods and branched spines. McLaren states that it should make a good street tree on this account, since the spine-covered branches would cause boys to fight shy of climbing the trunk. The spines are specially developed branches. Most of them branch near the base to form a cross which has caused the tree to be called the three-thorned acacia and the acacia of the Passion.

The first term of the formidable scientific name of this species is in honor of Gottleib Gleditsch, a German botanist; the second from the long threepronged spines on the trunks and branches. The large broad brown pods which bear the seeds of the tree are conspicuous in late summer and remain on the tree nearly all winter. The delicate, open foliage which gives the tree such a light and graceful aspect, comes out late in the season. It is bright green in the spring, turning to clear yellow shortly before leaf-fall. Fragrant greenish flowers appear in racemes early in summer.

The honey locust attains a height of fifty to serenty-five feet, and has spreading branches which form a low, spreading, rounded top. Because of its fine foliage the tree does not give as dense a shade as some trees, but in other ways it is very desirable for planting on streets and highways. It grows rapidly on any ordinary good soil, and is one of the few leguminous trees that will stand alkali. It requires very little irrigation and is free from insect attacks. Some objection has been found to the tree on account of its sharp thorns which makes pruning difficult. This characteristic, however, has been made use of in forming impassable hedges by planting the trees thickly and pruning them severely. For those who object to the tree because of its thorns a thornless variety has been developed which can be obtained from several nurseries in the state.

\section{ASHES}

Around no other tree has there gathered more legend and superstition than around the ash. To the old Northmen it was the tree of trees, the mystic Yggdrasil beneath whose shade the gods sat daily in council. According to the "Edda," their sacred books, an eagle rests on the summit of this mystic tree to observe all that passes in the world, while a squirrel constantly ascends and descends to report those things that the eagle may not have seen. Ser- 
pents twine arcurd the trunk, and from its rcots flow two streams, that of the knowledge of things past and that of the knowledge of things to come.

Scandinavian mythology relates that Odin made the first man from a piece of ash which he found on the seashore, and so the Vikings were called the Astmen. They used the wool of the ash for spear-shafts and axe-handles, and their ships were fashioned out of it since they helieved it had special power to withstand evil hoth in the day of battle and of storm.

The (jrecks also had a tradition of the origin of man from an ash, and its wood was deemed worthy to form the spear-handles of Achilles and other of their heroes.

In the middle ages the ash was supposed to be a safeguard against witches especially if it was made a "Shrew Ash" by hurying a live shrew-mouse in a hole in its trunk. It was believed that leaves and twigs taken from such a tree were a sovereign remedy for cattle suffering from cramp, which was supposed to be due to a shrew-mouse having run over the suffering part. Ash leaves were reported to cure warts, provided one said to the tree, "Ashen tree. Ashen tree, pray buy these warts of me," as one placed the leaves on the warts. Serpents were supposed to have an aversion to the ash, and it was reported that they" would "sooner run into the fire than into the boughs, and that they dare not so much as touch the morning and evening shadow's of the tree."

The ash has been called the Venus of the forest because of the airiness in its foliage due to the subdividing of its leaves. There are thirty to forty species in the genus Fraxinus to which it belongs, growing mostly in the temperate regions of the northern hemisphere. In North America, sixteen species are recognized, the white ash being the most beautiful and useful of the American species. The English ash is attractive with its fine foliage and black buds to which Tennyson compared the jet blackness of the hair of the gardener's daughter as being "more black than ash buds in the front of March."

The smooth ashen-gray bark of the bole is supposed to be the origin of the name ash. The flowers come first, and then the leaf-buds burst, displaying tiny leaflets laid together like the pleats of a fan. As the leaves open each leaf is composed of a terminal leaflet and a number of lateral leaflets arranged in pairs along the midrib. The fruit ripens in the fall and hangs on the trees in clusters through the winter. The fruit is often called ash keys, the botanical 


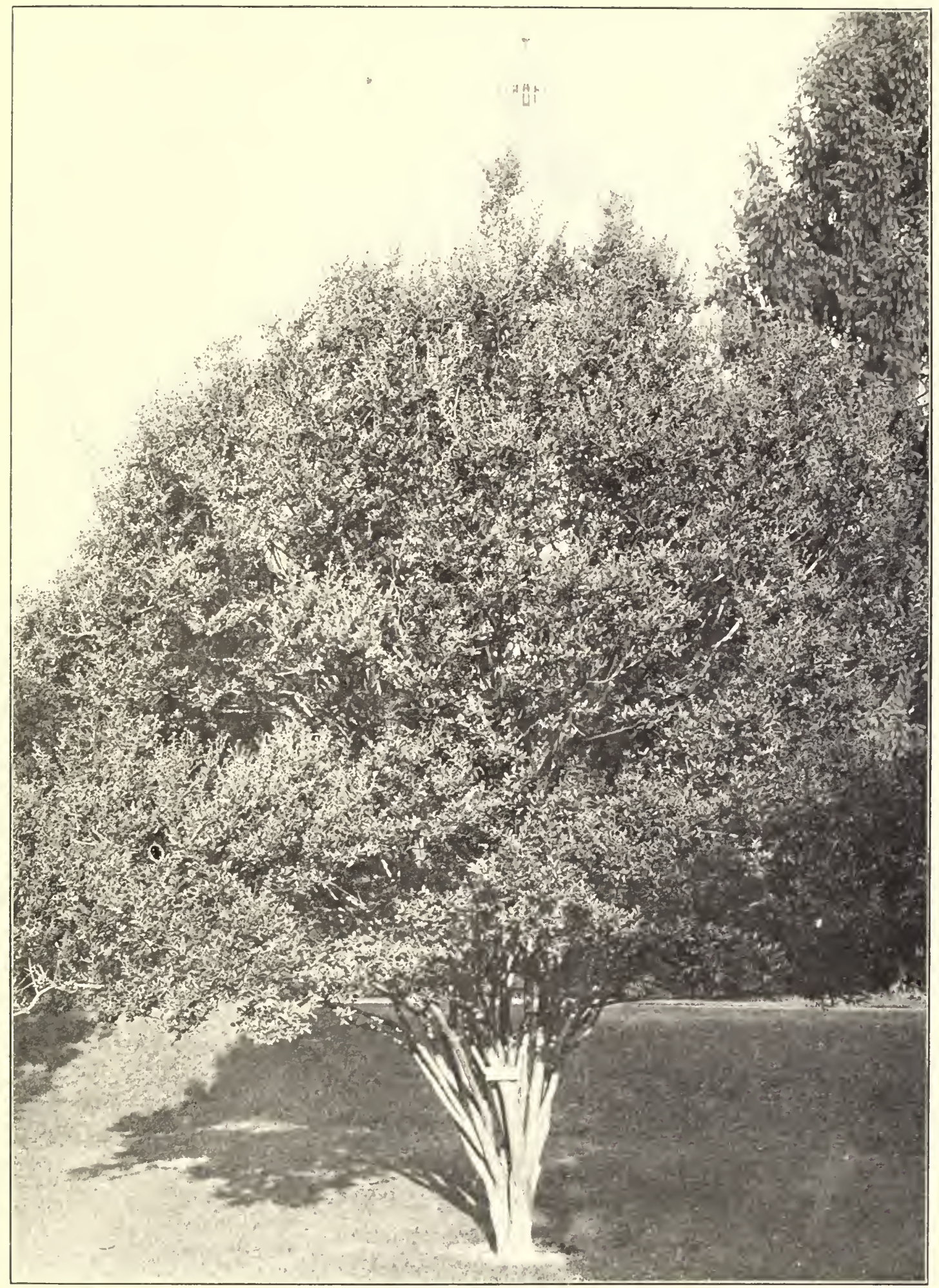

Plate 33. CRAPE MYRTLE. Sacramento.

A small tree with very smooth bark which blooms freely through most of the summer. 


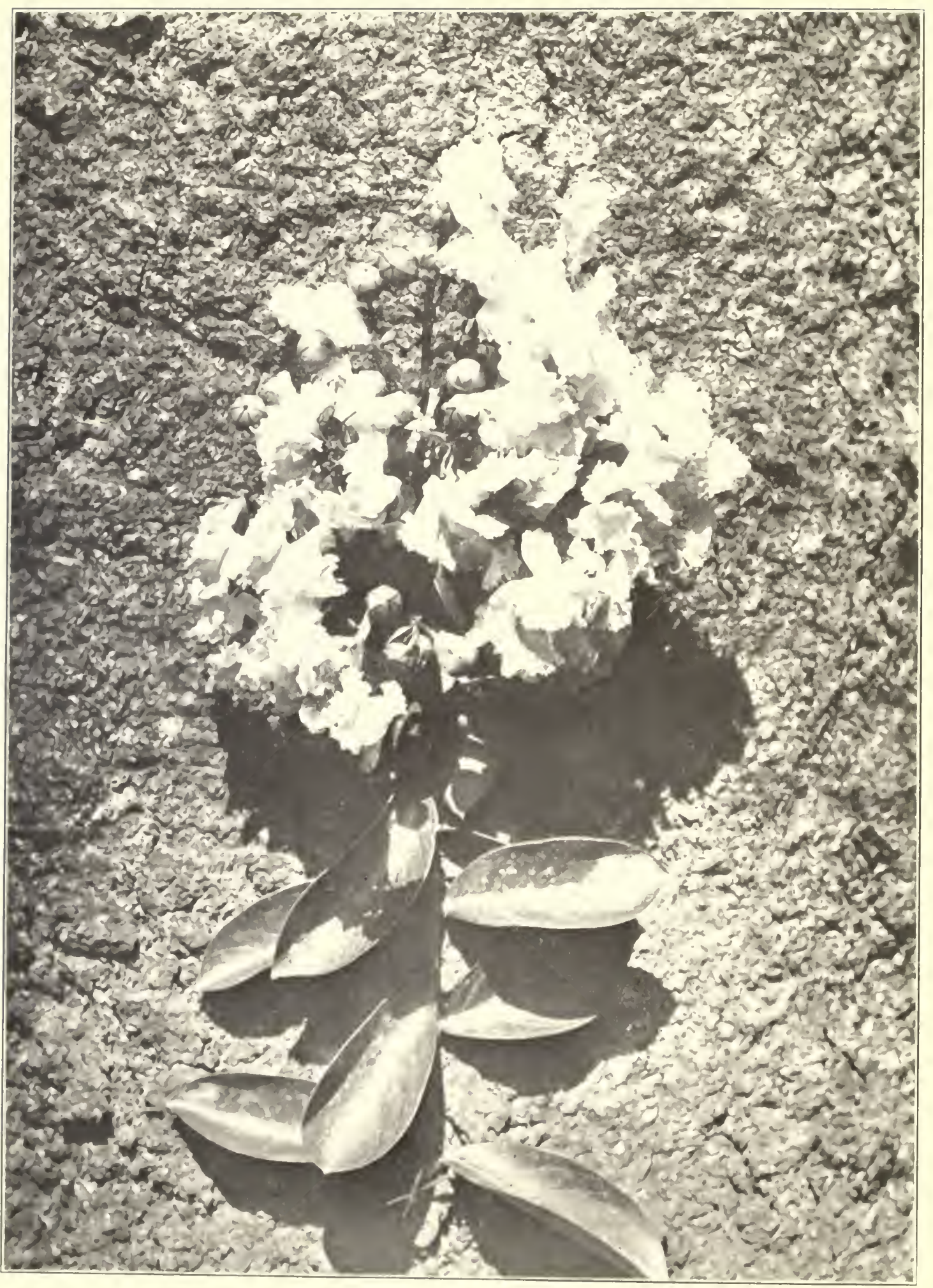


name being the samara. Each key is long and flat with a seed shaped as a long oval at the stem end and continuing into a flat leathery wing.

\section{WHITE ASH}

The white ash (Fraxinus americana) is native from Newfoundland and Nova Scotia west to Minnesota and south to Florida and Texas. It reaches its best development on rich moist soil where occasional specimens 120 feet high and from five to six feet in diameter are found. It grows straight and symmetrical, and forms a broad, rounded head which bears dense, graceful masses of leaves. In the fall the leaves change color, and as they drop from the tree expose a characteristic open head with erect rigid twigs with an opposite arrangement.

It is hard to understand why white ash has not been planted more extensively in California since it has many characteristics that recommend it for a shade tree. It is a rapid grower, is hardy; and has few inscct enemies. For ornamental purposes, its open habit of branching affords a desirable contrast to bring out the beauties of other trees with more delicate branch systems, and its light green leaves make an effective color effect against darker foliage. It can be easily transplanted on account of its finely divided root system, and should do well under good soil and moisture conditions.

\section{ARIZONA ASH}

Arizona ash (Fraxinus velutina) is a little known tree which is destined to be widely planted in California along roads and highways because of its ability to do well under adverse conditions. The tree grows naturally from western Texas to the Owens Lake region in southern California, where it inhabits the banks of the streams or borders of springs. In its native state it is a small tree, from fifteen to thirty feet high, but under cultivation it reaches a height of seventy-five feet.

It has large, compound, willow-like leaves, gracefully drooping branches, and large panicles of wing-like fruit in the fall. It grows fast, and forms a symmetrical, round top, which affords sufficient shade, although some sunlight always finds a way through its irregular, wavy foliage.

Arizona ash has the great merit of growing well in alkaline soil where hardly any other tree will do, and is particularly well adapted to the arid 
regions of southern California. That it will do equally well in the Sacramento and San Joaquin valleys is evidenced by a sturdy row on the highway near Bakersfield. Kern County has recently planted a large number of Arizona ash trees on the barren seventeen-mile stretch of state highway running from Bakersfield to the foot of the pass over the mountains to Los Angeles, and under the care of the California Highway Commission they are doing well, though struggling against extremely adverse conditions.

\section{BIRCHES}

There is some difference of opinion as to which tree is king, but there is no doubt as to the right of the birch, the apotheosis of daintiness and charm, to the title of Lady of the Woods bestowed on her by Coleridge.

The genus Betula, to which the birches belong, embraces some thirty-five species of small trees all of which, except one South American species, are inhabitants of cool, northern regions. Thirteen species are found in North America of which ten are trees. Two groups are distinguishable, the white or paper birches, and the yellow or black birches. The white birches with their pure white bark. graceful foliage and slender branches are the ones chiefly used for ornamental purposes.

From the earliest of times birch bark has served as a material on which to write, and the books of Numa Pompilius of Rome, which were compiled in 700 B. C., are said to have been written on it. The American Indians considered a birch bark canoe, ribbed with ceda, bound with larch roots and with its seams made water safe with pine balsam, an ideal boat. They also used the bark as a covering for their lodges.

In times past the giving of a birch wreath was a token of love, and in Wales today the Maypole is always macle of this tree. It has always been associated with the spirits of the dead and with those that mourn, an association that a poet has thus expressed:

"Weeps the birch of silver bark with long, clishevell'd hair."

It is stated that the fasces carried by the lictors before the magistrates of ancient Rome were made of birch rods. The Russian believes the birch tree to be a symbol of good health and is flogged with birch switches until he perspires when taking a sweat bath. Many youths in the region where the 


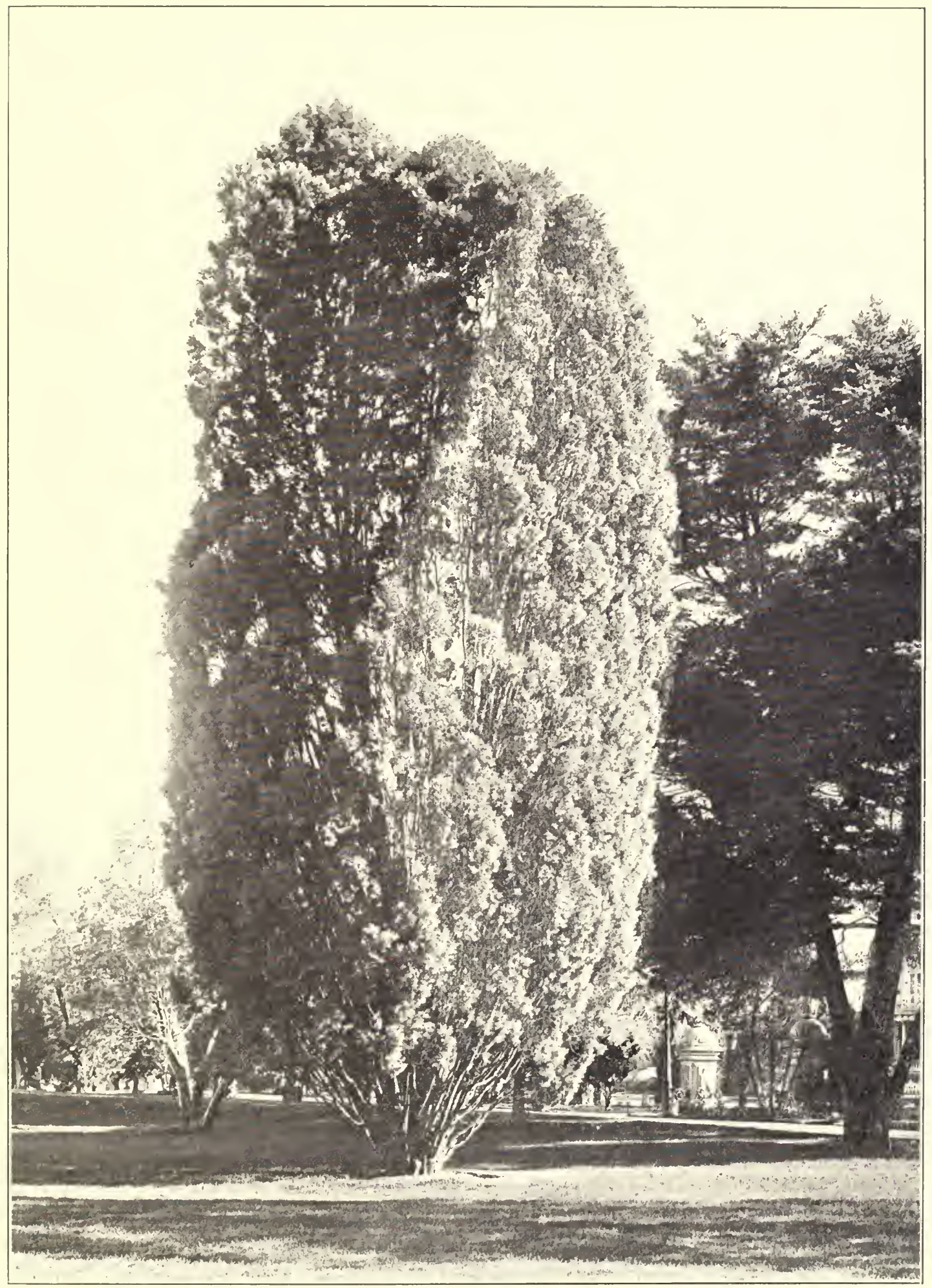

Plate 35. GUADALUPE CYPRESS. Sacramento.

A native of the Guadalupe Island, which has foliage of striking blue color which often causes it to be called "Blue Cypress." 


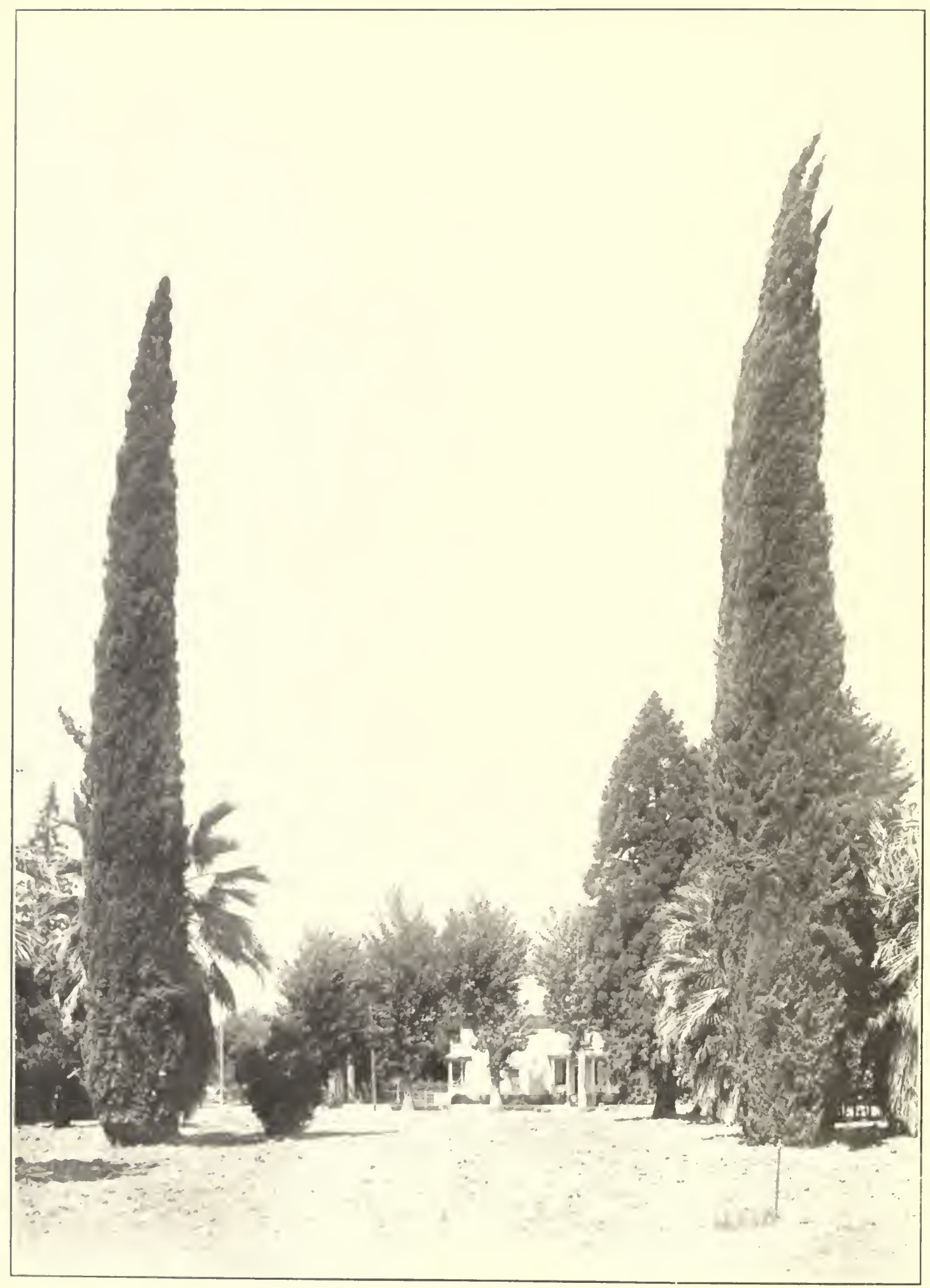

Plate 36. ITALIAN CYPRESS, Visalia.

"There stands a proup of cypresses-

Whose branches the air plays among, but not

1)isturbs, fearing to spoil their solemn grace. -Shelley. 
birch is abundant have painful recollections concerning this use of its branches. In this connection the Dean of Wells in 1568 wrote the following:

"I have not red of any vertue it hath in physick; howbeit, it serveth for many good uses, and for none better than for betynge of stubborn boys that either lye or will not learn."

\section{WHITE BIRCH}

The European white birch (Betula alba) is closely related to the paper birch which is a native of northeastern United States. It is the most handsome of the white birches and is thought by Hamerton to be one of the most beautiful of trees.

"The birch is always beautiful in herself," he says, "and not the least beautiful in winter, when all her light woody structure is distinctly visible, from the silvery trunk to the dark purple sprays. In spring her light green foliage strikes the eye as crude, but in autumn the thinly scattered little leaves of pale gold tell with the greatest brilliance amongst the darker shades of the forest, and the whiteness of the stems is brilliant against the russets and purples and dark greys."

The white birch is a short lived tree which reaches a height of about fifty feet with a trunk seldom over a foot in diameter. The trunk is a definite column to the tip of the tree and gives off branches which are considerably slighter and darker. From these branches droop still slighter twigs which give the tree its daintiness and charm. The silvery bark is emphasized by many transverse markings known as "lenticels" which are spaces where air is admitted to the living tissues beneath the bark.

There are a number of varieties of the birch, one of the most beautiful being the weeping cut-leaved birch (Betula alba laciniata pendula). This is common in parks and estates and is used to some extent on narrow roads or streets where a marked contrast in growth is desired. Single specimens on lawns are very attractive since the fine slender shoots, deeply cut leaves, and snowy white trunk are revealed in all their beauty.

The birches do best in the coast region where there are favorable soil and atmospheric conditions. Their natural habitat is in cool regions and they will not thrive where there is too much heat. The growth is slow, but under good care the birch will form a good head and make a splendid small tree for 
localities where a light shade is desired. Its beauty of outline is w'ell shown in Mlacll'herter's picture of a group of birches entitled "The Three Graces."

\section{BLADDER-NUT TREE}

The bladder-nut tree (Koelreuteria paniculata) which was named after J. G. Koclreuter, professor of natural history at Karlsruhe, is native to China and Japan. It is a medium sized tree with a picturesque branch habit and a heavy foliage of finely cut, dark-green, compound leaves. Small yellow flowers are borne in large terminal panicles followed by conspicuous bladkler-like pods. It is sometimes called the "varnish tree" because of its glossy foliage.

This tree flourishes in the smoke-infested towns of England such as in the outskirt districts of Liverpoool and Manchester, and has done well under adverse conditions of soil and moisture in California. It is said to endure alkali better than most trees which entitles it to consicleration in some parts of the state.

\section{BOTTLE-BRUSHES}

The hottle-brushes are mostly Australian trees and shrubs which are widely planted in California because of their beauty and hardiness in withstanding drought and abuse. The bottle-brushes embrace several genera but the name is especially applicable to the genus Callistemon, a word derived from two Greek words, kallos (beauty) and stemon (stamen). In most of the species the stamens which protrucle from the blossoms are of a beautiful scarlet or crimson color. The flower clusters resemble bottle-brushes in shape which gives the common name.

Callistemon lanceolatus is one of the most attractive of the bottle-brushes. It has an erect growth and reaches a height of about twelve feet. In Australia it is thirty feet tall and eighteen inches in diameter. The wood, which is heavy and hard, is used there for mallets. It has very short and broad leaves and bright red flowers.

The genus Melaleuca has not as showy flower clusters as Callistemon, but the various species are more symmetrical in outline. All species are hardy in nearly every locality in California except in mountainous districts. A luxuriant development is secured in some parts of the state under a combination of warm summers and moist soil. 


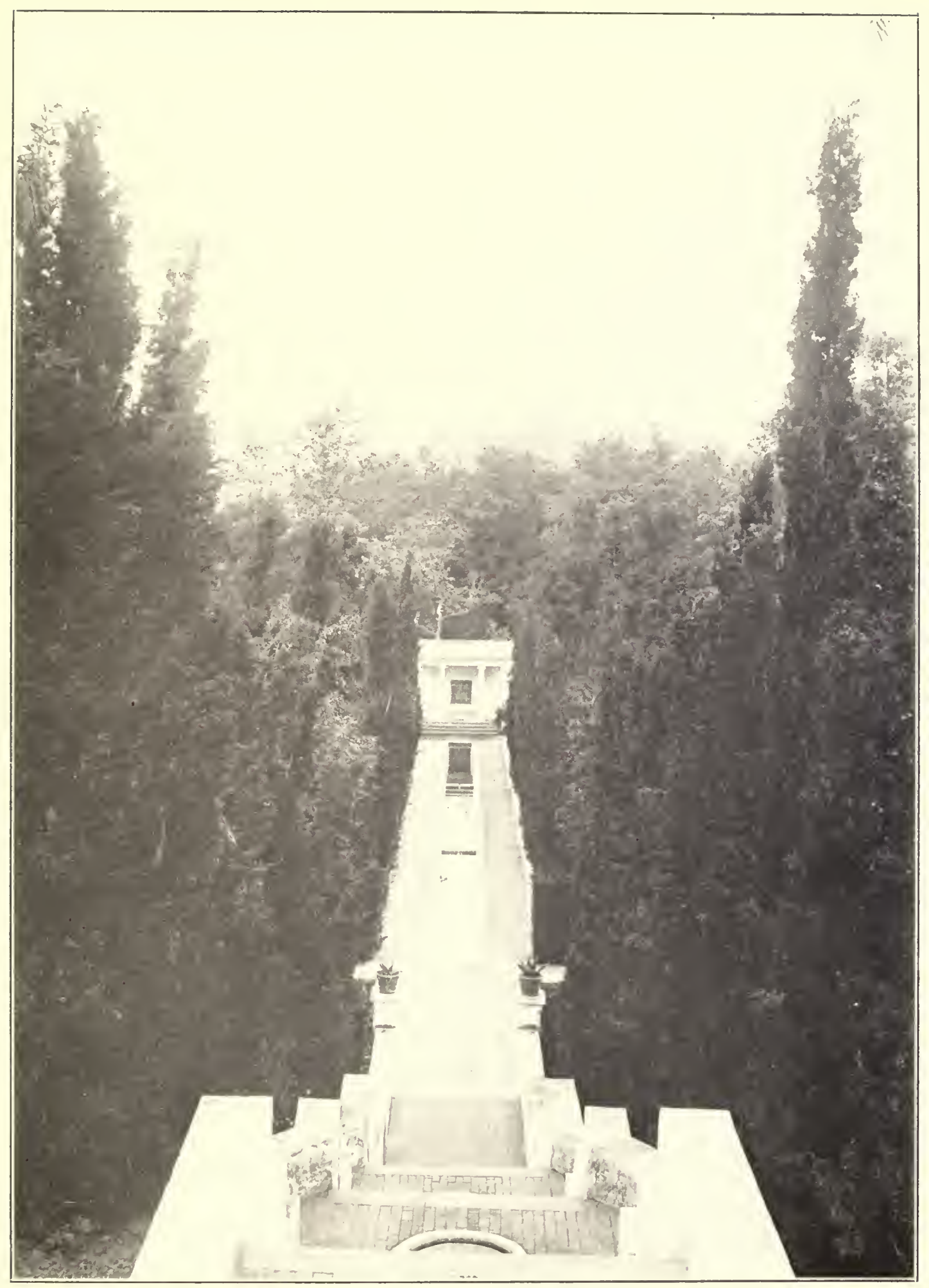

Plate 37. ITALIAN CYPRESS. Santa Barbara.

The use of Italian cypress to secure pleasing effects is well shown on this estate in Santa Barbara. 


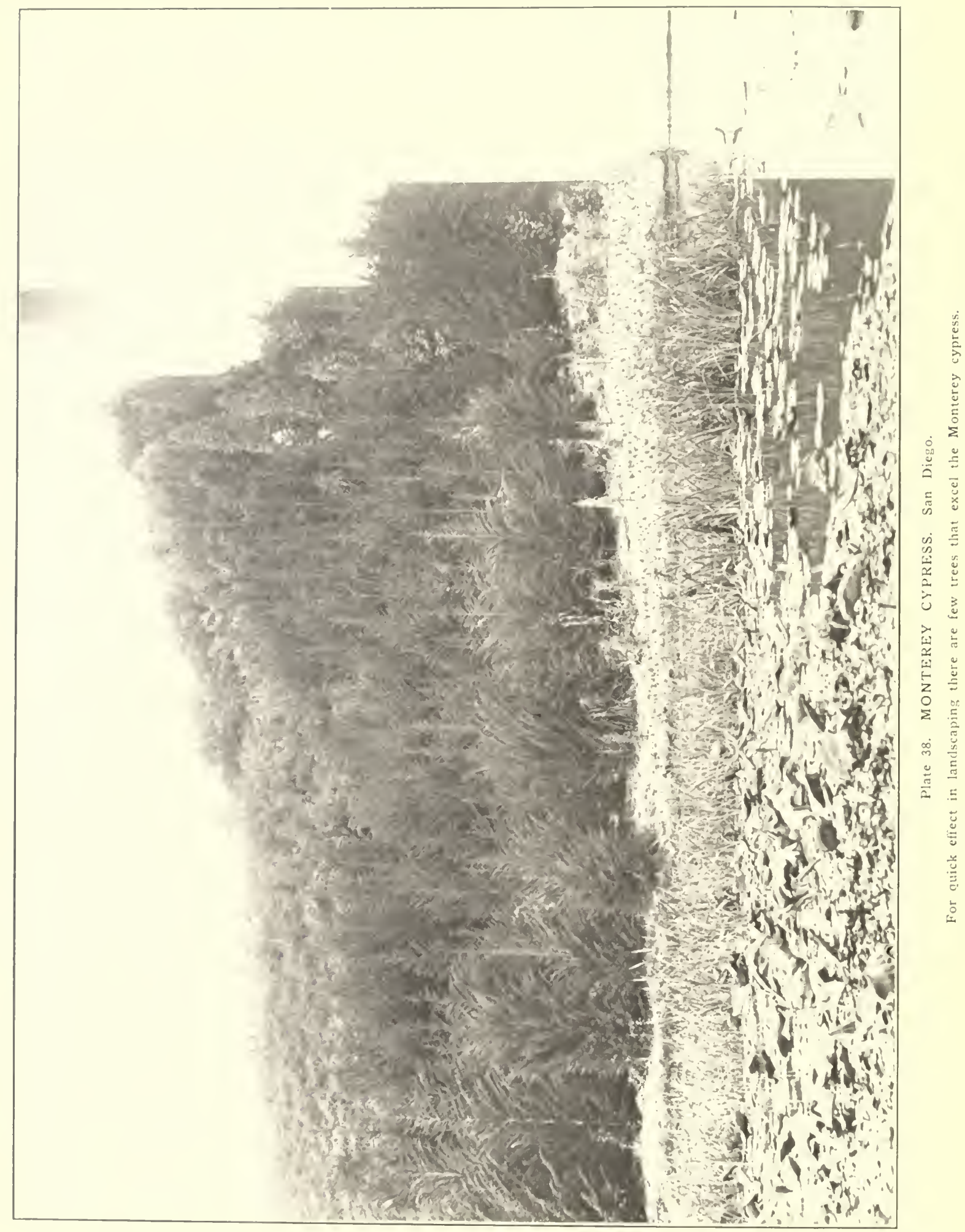


The bottle-brushes are favorites in California gardens. They are easily pruned and are especially good for parks, schoolgrounds and private estates. They grow well in any fair garden soil and require very little attention if the ground is cultivated once a year and kept loose on the surface.

A notable feature of the Melaleucas is their striking shred-like papery bark, which peels off in wide layers and leaves the trunk clothed in a lustrous corky layer of rare beauty.

\section{BRISBANE BOX}

The Brisbane box (Tristania conferta), named in honor of Tristan, a French botanist, is an Australian tree that is widely used in New South Wales on city boulevards. It is a handsome evergreen with broad shining leaves, somewhat resembling the broader form of eucalyptus leaves, clustered on the ends of the branches. The flowers are white and star-shaped with fringes of stamens which give them a very unusual appearance.

This tree has a good form and affords an abundance of shade. Under favorable conditions it reaches a height of 100 feet. It stands drought remarkably well and is hardy in central California. Its chief objectionable feature is the dropping of its leaves throughout the year. It is also badly affected with scale at Berkeley.

\section{CALIFORNIA LAUREL}

California laurel (Umbellularia californica) derives its generic name from . the Latin umbella, a sunshade. It is one of the most characteristic native trees of California, and is common along water courses in the coast ranges and within the foothill zone on the west slope of the Sierras. It reaches its best development on flats along the northern coast where it frequently becomes a tree eighty to 100 feet high and five to six feet in diameter.

Sargent describes it as "one of the stateliest and most beautiful inhabitants of the North American forests, and no evergreen tree of temperate regions surpasses it in the beauty of its dark dense crown of lustrous foliage and in the massiveness of habit which makes it one of the most striking features of the California landscape and fit it to stand in any park or garden."

The California laurel has many names, such as bay tree and pepperwood. The leaves are highly aromatic giving an odor much like those of the bay 
laurel of the ancients. The common name for the California laurel in Oregon is myrte. The "black myrtle" of the millmen is produced by sinking logs in water to improve the color of the wood for furniture and interior finish.

California laurel is a handsome tree in cultivation, but should be planted under advantageous conditions, since it tends to become top-heavy and is liable to be blown down. The trees are apt to develop several leaders, but if kept to a single leader it forms a fine pyramid and makes a splendid tree. No evergreen tree is better adapted for forming groups of dense foliage if given a suitable place. In the hot interior valleys it is apt to be attacked by scale, and, on that account, should be given a shady situation and plenty of water during the dry season.

\section{CAMPHOR TREE}

The camphor tree (Cinnamonum camphora) is a native of China and Japan which has become so thoroughly naturalized in California as to be considered a genuine "old timer." It is one of the most popular ornamental trees in southern California, where it is a favorite evergreen for street planting, due to its handsome, dense foliaged crown.

The leaves are bright green, highly polished, and throughout the summer give the tree an appearance of freshness. The new foliage is very attractive in its reddish-pink splendor at the tips of the branches. The mature form is dome shaped, the trees rarely exceeding forty feet in height. Good growth can be secured by giving the trees care, but if they are neglected they will become stunted and irregular in shape.

The camphor tree is not confined to southern California, but thrives in many sections of the central and northern part of the state, where it displays quite a degree of immunity from frost at low elevations. It lends itself to wide parkings on city streets and makes a handsome shade and ornamental tree on lawns. Like most other evergreen trees, there is some dropping of leaves throughout the year, but not enough to cause an excessive litter.

The camphor of commerce is extracted from the wood, bark and leaves of this tree, and there is a distinct odor of camphor to the leaves which is brought out when they are crushed in the hand. 


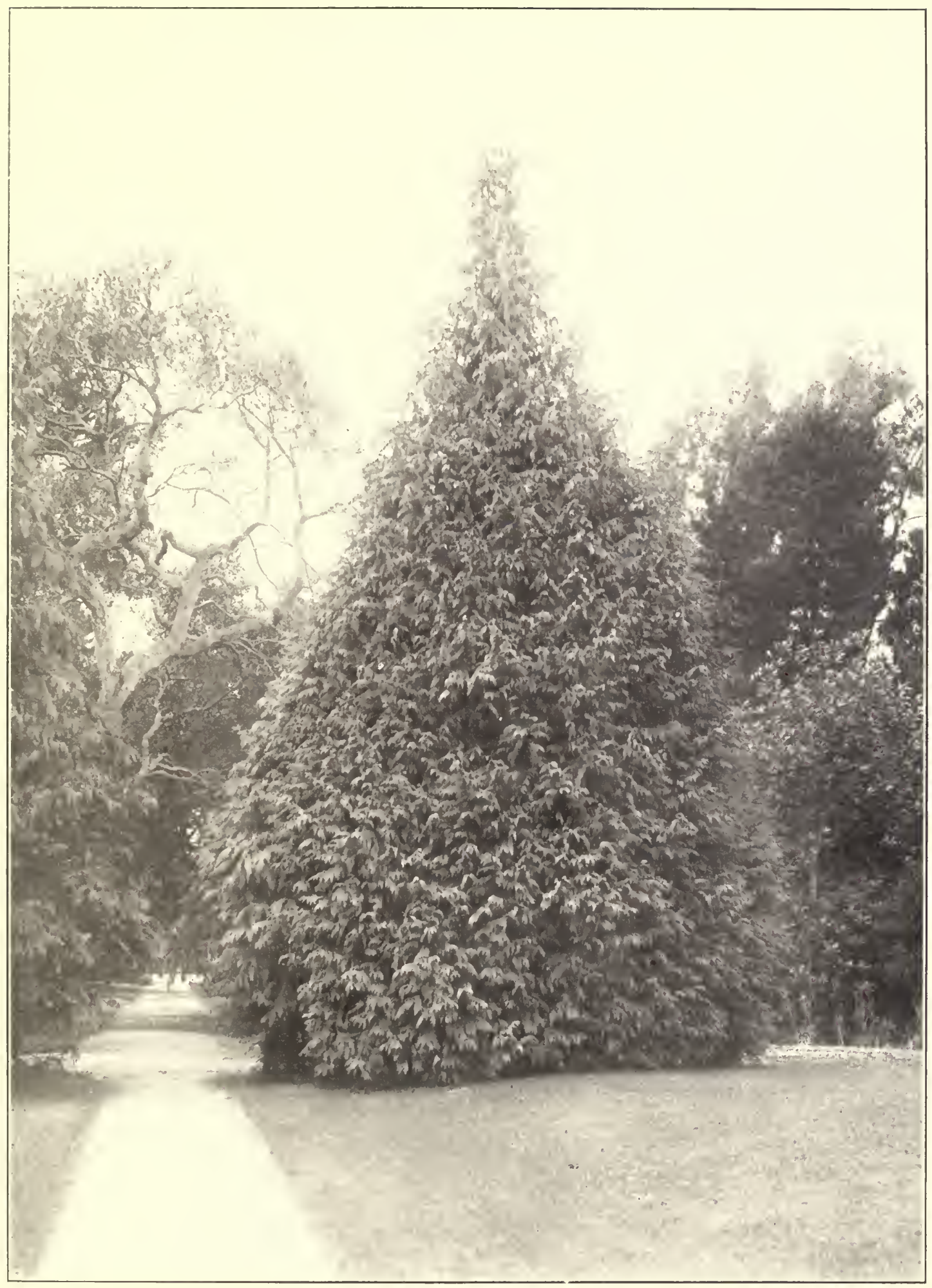

Plate 39. LAWSON CYPRESS. Del Monte.

"Here, where upon the velvet lawn The cedar spreads its shade." - Procter. 


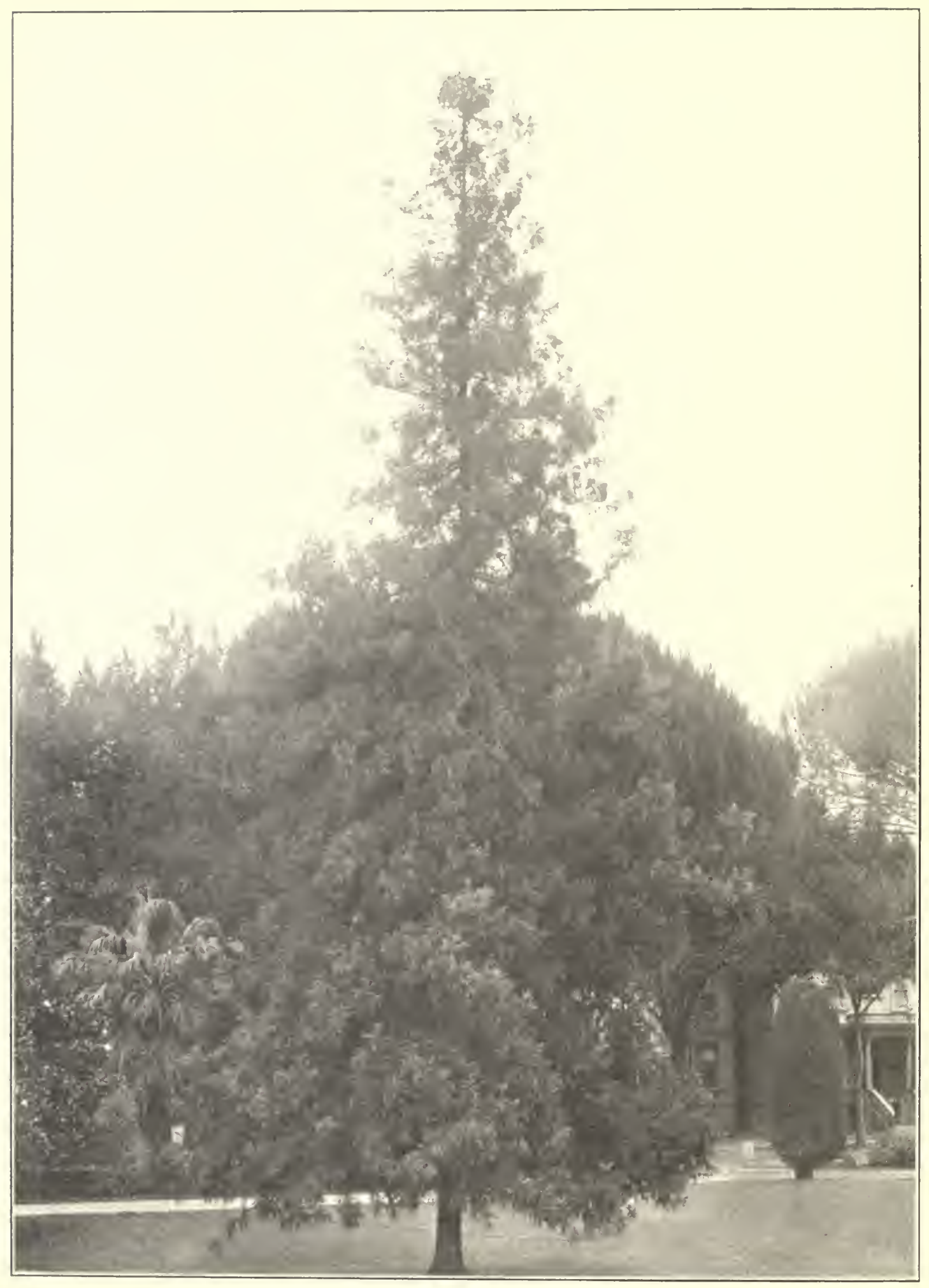

Plate 40. JAPANESE CEDAR. Sacramento.

The national tree of Japan, which has an antiquity that can be traced to a very remote geological period. 


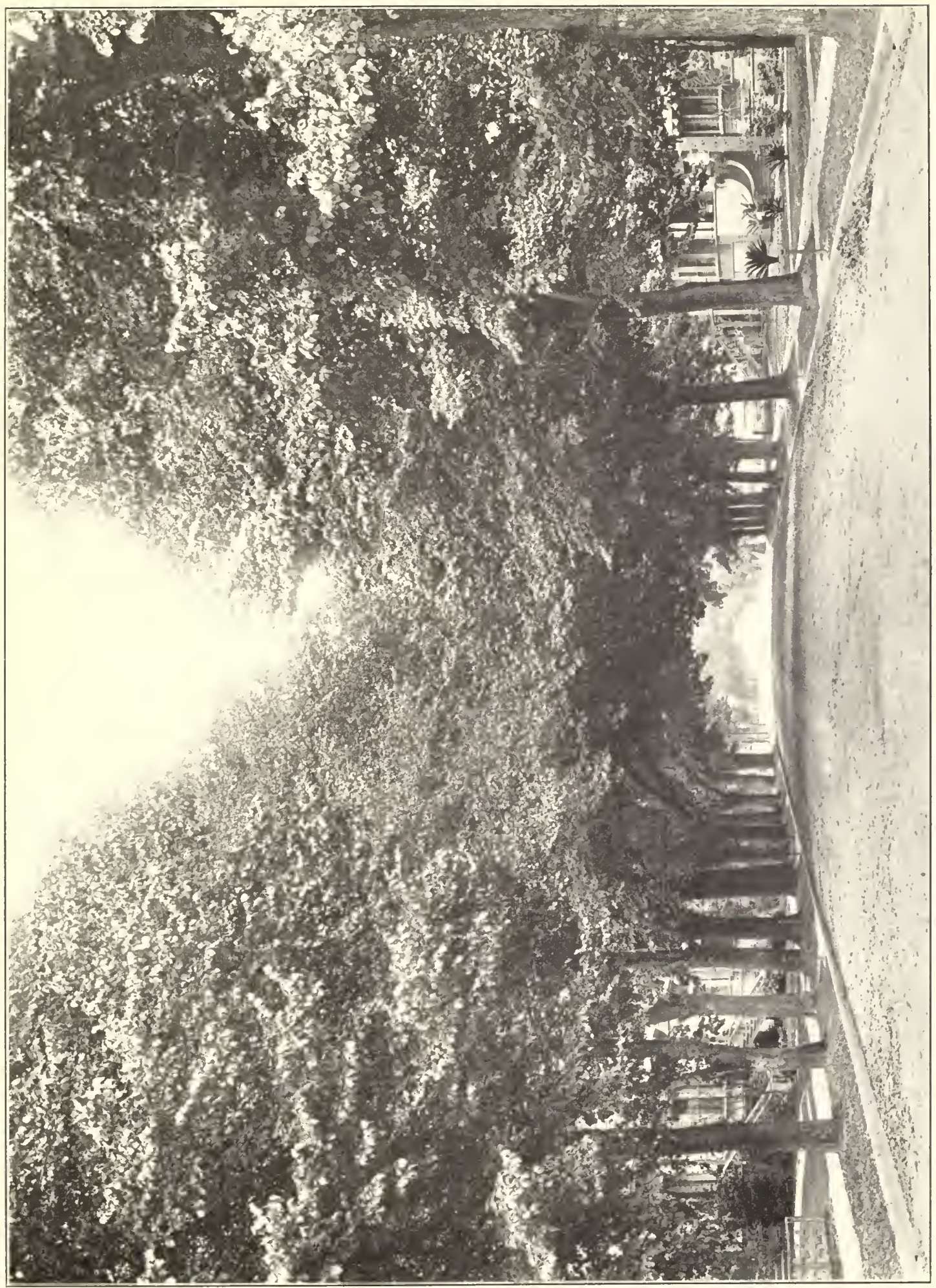

 


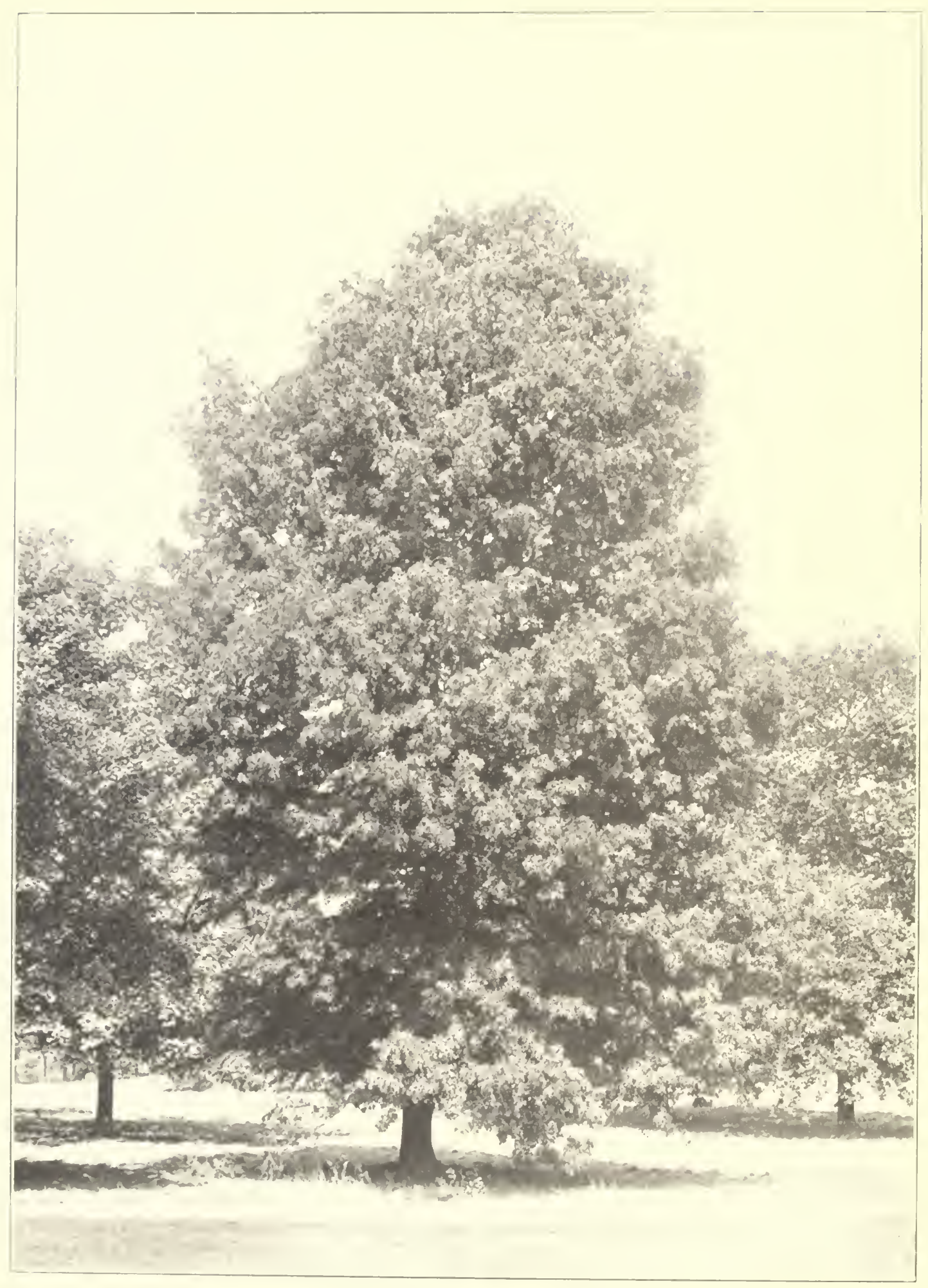

plate 42. ENGLISH ELM Burlingame. 


\section{CAPE CHESTNUT}

The Cape chestnut (Calodendrum capensis) takes its generic name from a Greek word meaning beautiful tree. It is one of the handsomest deciduous trees of the Cape of Good Hope, where it is called "wild chestnut." In Africa this tree reaches a height of seventy feet, but only a few small specimens are found under cultivation in California, all of them being confined to the southern part of the state.

It is a symmetrical tree with attractive foliage and large panicles of white or flesh-colored blossoms which are sometimes seven inches across and six inches deep. The seeds, which resemble chestnuts, are black and shiny. The leaves, which are four or five inches long, are studded with oil cysts which look like translucent spots when held to the light.

This rare and beautiful tree is an ornament to any private ground, and under favorable conditions and with good care should do well in most parts of southern California.

\section{CAROB}

The carob (Ceratonia siliqua) belongs to the legume family. The generic term is from the Greek (keroma) meaning horn, in reference to the form of the pod, the scientific name of which is silique. This tree, commonly known as St. John's bread, because of its edible pods, is native to the eastern shores of the Mediterranean Sea. It was taken by the Greeks into Greece and Italy, and by the Spaniards into Mexico and South America. Its first appearance in this country was in 1854 from Spain. Seeds were first planted in California in 1873 at Los Gatos, and at the present time the tree is successfully grown as far south as Imperial County and as far north as Butte.

The carob tree reaches a height of forty to fifty feet and has evergreen foliage made up of glossy, green, compound leaves, making it a tree of great beauty. The head is rounded and often branches in such a way that the weight of the branches causes them to split and ruin the form of the tree. This is its chief objection since in other ways the carob is well adapted for street and ornamental planting. The majority of carob trees are dioecious, that is, have staminate or male flowers on one tree and pistillate or female flowers on a different tree. The pistillate flowers develop into pods four to ten inches long, which are thick and tough and filled with a sweet pulpy substance in which the flat, bony seeds are embedded. 


\section{CASUARINAS}

The generic term Casuarina is supposed to be taken from Casuarius, the genus to which the cassowary, a large bird from the East Indies, belongs. The name was. given the trees in this genus because of the resemblance of their branches to the feathers of the cassowary. The trees are commonly known as beefwoods or she-oaks. The redness of the wood accounts for the name beefwond, and its hardness for its association with the oaks.

The Casuarinas embrace about twenty-five species, which are found naturally in Australia and the East Indies, where they grow under adverse conditions of soil and moisture. This has led to their use in this country for planting in certain localities, especially where alkali is present. It has been found that they will resist alkali and drought better than most trees, which is the main justification for their use.

The principal species planted is the she-oak (Casuarina stricta). It has a peculiar form suggestive of its drought-resisting qualities. It has no leaves, and the branches are jointed like those of the equisetums. This gives it a thintopped appearance, which on mature trees is suggestive of the habit of the pines. It reaches a height of thirty-five to forty feet and under favorable conclitions makes a fairly rapid growth. It is planted on some streets in southern California chiefly because of the oddity of its appearance, and the little care that it requires.

Casuarina equisetifolia has tiny, bur-like multiple fruits which cling to the branches like little stars and shed quantities of tiny light brown winged sceds. It has been successfully grown in plantations in the Berkeley hills.

\section{CATALINA IRONWOOD}

The Catalina ironwood (Lyonothamnus floribundus var asplenifolius) is native only to Santa Cruz, Santa Rosa, Santa Catalina and San Clemente islands, off the coast of southern California, and was first brought to the mainland at Santa Barbara in 1894 . It flourishes there, as well as in the botanic gardens at the University of California, where a tree fifteen years old is forty-five feet high and ten inches in diameter. It is called ironwood because of the extreme hardness of its wood.

This rare species is worthy of trial as a street tree because of its erect habit of growth, moderate spread and narrow crown. The leaves are divided 


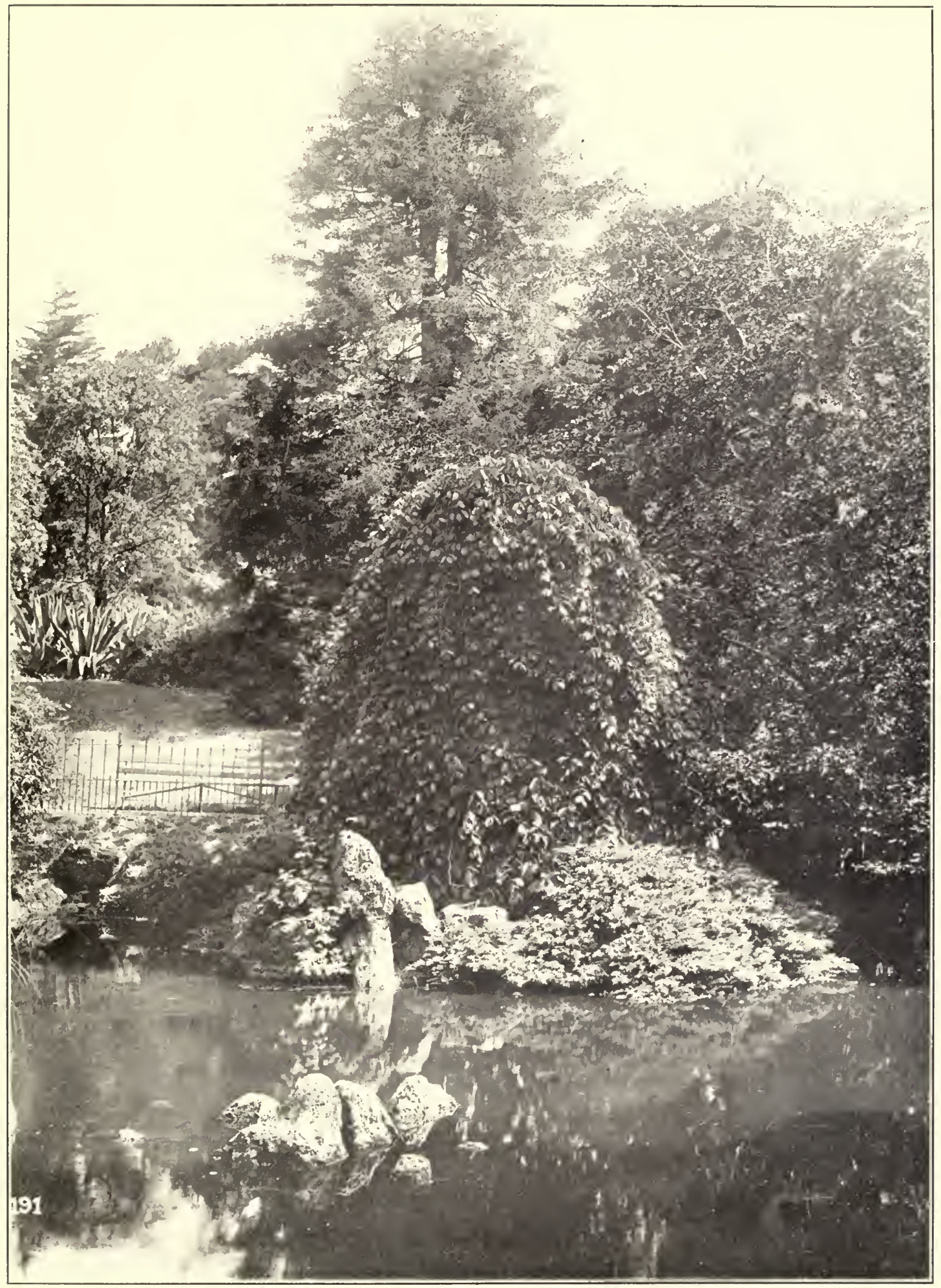

Plate 43. CAMPERDOWN ELM. Golden Gate Park.

A grafted elm on which the limbs grow outward and downward giving it a weeping appearance. 


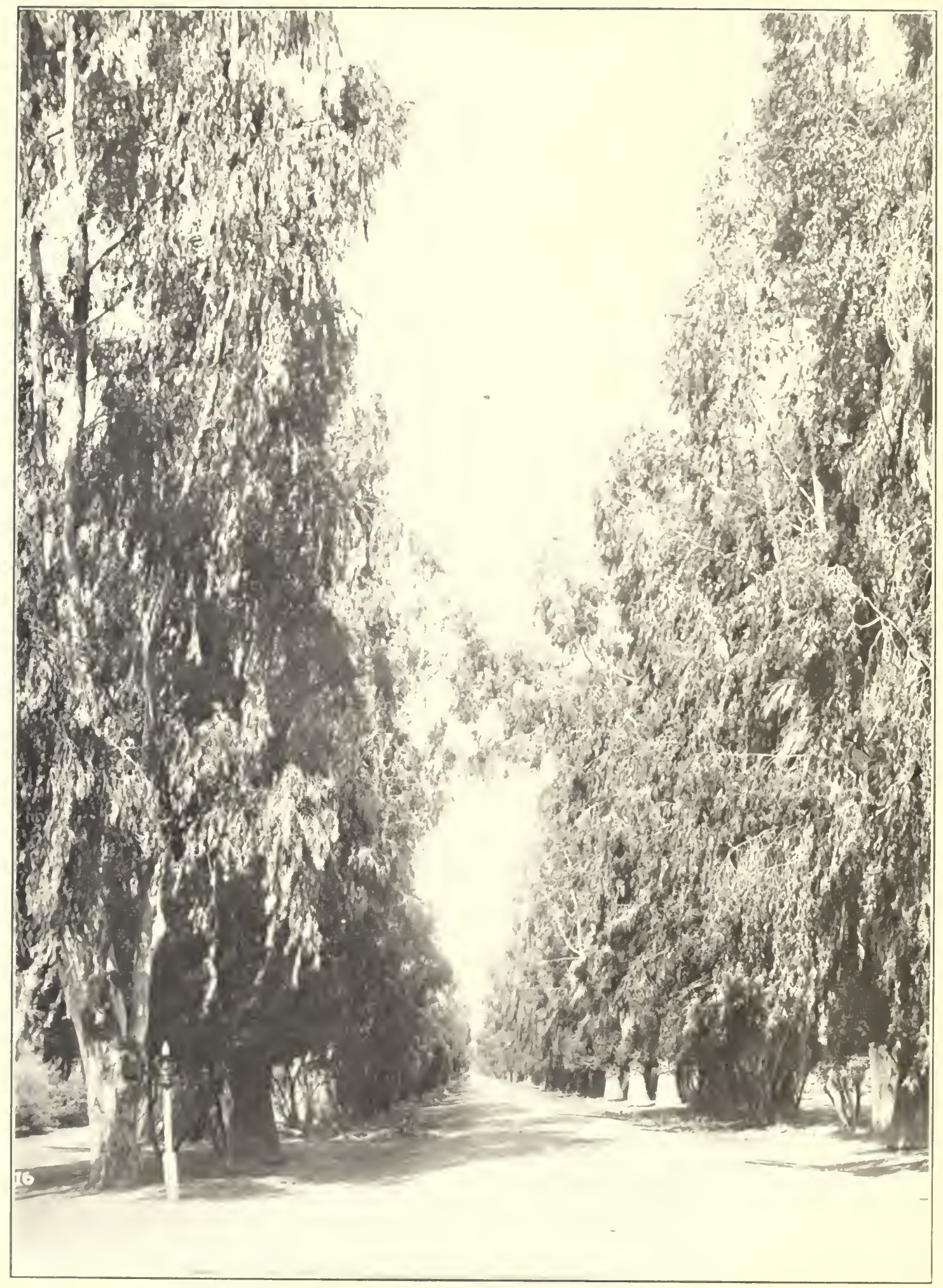

Plate 44. EUCALYPTS AND PALMS, Fresno. ums, hence they are commonly known as gum trees. The Kearney boulevard near Fresno, which is lined witl 
into long, narrow leaflets, which are cut nearly to the midrib into triangular lobes. It blooms in early summer, the blossoms being white and borne in large, dense clusters. The bark is reddish in color and is shed in long strips.

There have been no failures wherever the ironwood has been tried in the Coast region. It has not done well, however, in the interior region. As an ornamental tree it is best adapted to large grounds where its symmetrical outline and stately habit may be fully brought out.

\section{CATALPAS}

The generic term Catalpa is from the language of the Indians of Carolina, where it was discovered in 1726 . There are seven species of catalpa in the world, two in North America and the others in the West Indies and Eastern China.

The hardy catalpa (Catalpa speciosa) is most frequently planted, since it is the most symmetrical of any of the species. It is a medium-sized tree which is of interest because of its large heart-shaped leaves, clusters of striking, white flowers and odd fruit pods which hang on the tree during the winter These pods are commonly known as Indian beans.

The branches are long and heavy, forming an irregular round topped tree. The successive fall of the flowers, leaves, and fruit make the catalpa uncleanly, but it is comparatively free from insect pests, and on account of its showy characteristics is often planted on streets and lawns. It does well in the Coast region but is not a first choice species for street work in comparison with many other desirable trees.

\section{CHERRIES AND PLUMS}

The genus Prunus, the ancient Latin name for plum, besides including such orchard fruits as peaches, plums, cherries, apricots, and almonds, embraces many ornamental trees and shrubs. The most ornamental species are those from China and Japan, which are conspicuous because of their double blossoms and colored leaves. One of the first to bloom is the Japanese plum (Prunus pissardii), which was introduced into France by Pissard, gardener to the Shah of Persia. A portion of Hillegas avenue, Berkeley, is lined with these trees, which attract much attention in the early spring by their showers of white blossoms tinted with pink. A little later, reddish-purple leaves appear, followed in the fall by handsome light-red fruit. 
Catalina cherry (Prunus integrifolia) is a native of Santa Catalina and Santa Cruz islands, off the coast of southern California. It has shining evergreen leaves and produces a foliage often used for decorative purposes, as well as for low windbreaks. The blossoms are inconspicuous, of a greenish-white color, and are followed by small fruits of a small purplish-red color. This tree is planted on a street in Hollywood, where it forms a very dark green crown which gives a dense shade.

All members of this genus are small trees which are well adapted for narrow streets or parkings where large trees would be out of proportion to the buildings. They also are effective as "accent trees" in front of other shrubbery and trees. They are short-lived as a rule, but grow freely in any fairly good soil, and require little irrigation if the soil is kept loose and free from weeds.

\section{CHESTNUTS}

The chestnuts are confined to the northern hemisphere, and are widely distributed through eastern North America, southern Europe, northern Africa, western Asia, and central and northern China and Japan. Four species are distinguished of which two are found in this country. The finest chestnut trees in the "orld are in the southern Appalachian Mountains, where a tree seventy-fre feet in height and with a circumference of over thirty-three feet has heen found.

The "spreading chestnut tree" under which the village blacksmith worked is known to every school child. From its wood an armchair was made which was presented to the poet Longfellow on his seventy-second birthday, February 27,1879 .

The chestnut has many distinctive features. Mature trees have grayishbrown bark with broad, flat, irregular ridges separated by deep fissures. The leaves are six to eight inches long and about two inches wide with coarsely toothed margins. In the fall they assume soft shades of yellow and recl. In summer, after most other trees have bloomed, the chestnut blazes into a wealth of odorous, cream-colored blossoms, arranged on long, slender spikes. The nut-producing flowers are fertilized and grow into prickly burs, the sharp spines of which are Nature's protection against injury to the nuts. When the burs split they separate into four parts, revealing two to four shining nuts resting in a velvety brown bed. 


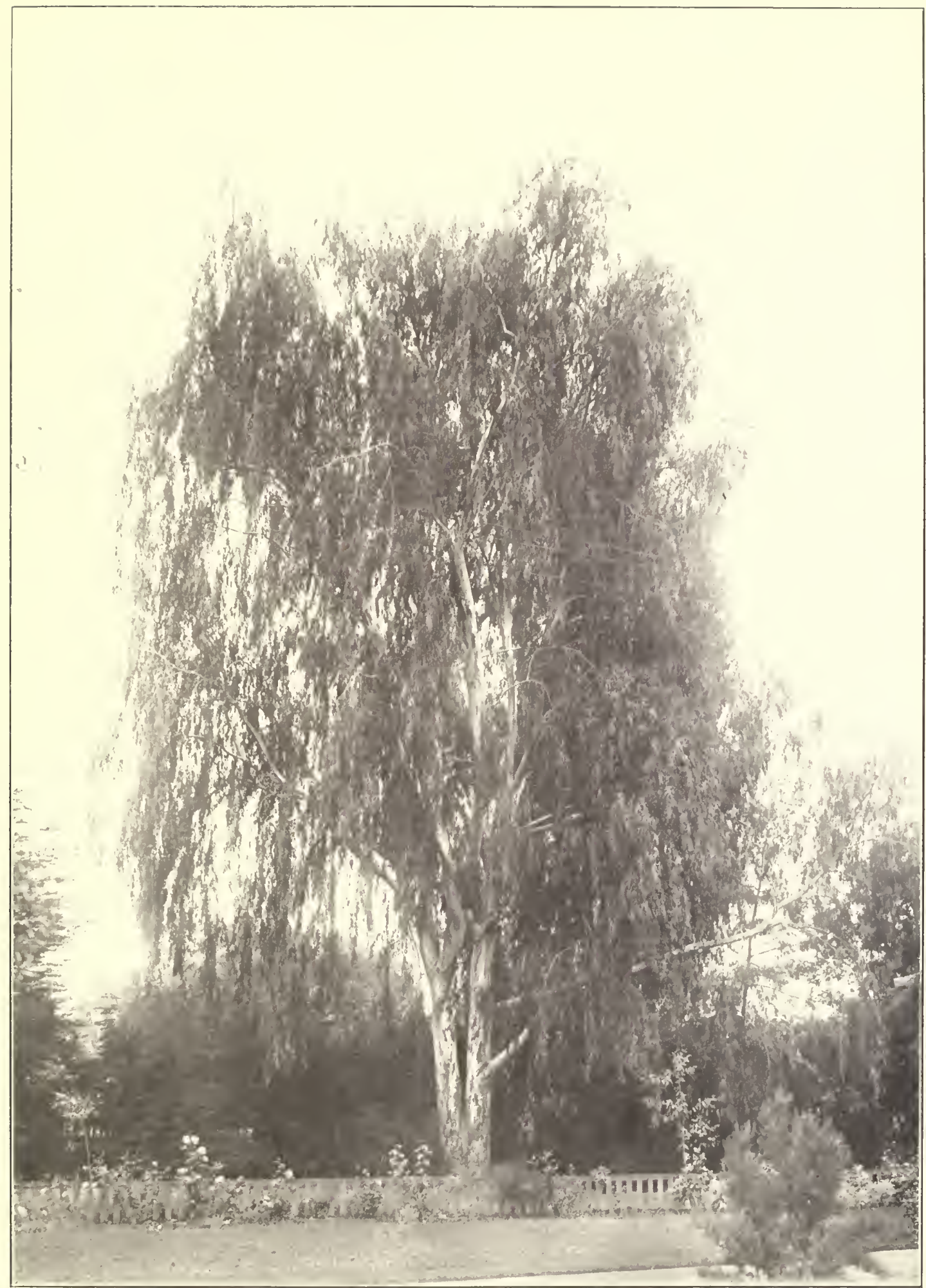

Plate 45. RED GUM. Pasadena.

The foliage of the older trees of this eucalyptus is reddish-white, which gives it its common name. It does not grow as large as blue gum, but stands more cold and drought. 


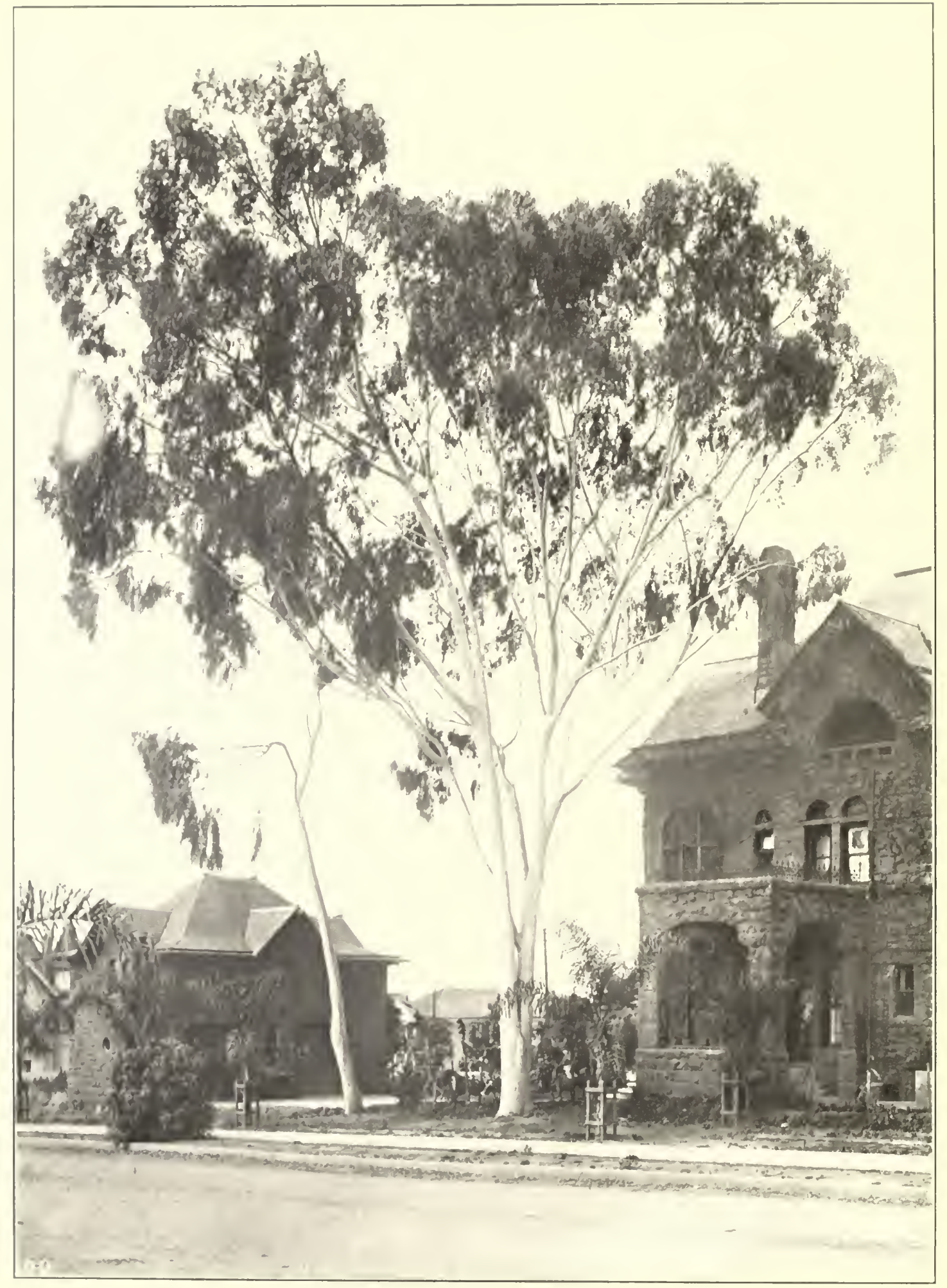

Plate 46. LEMON-SCENTED GUM. San Diego.

A fast growing cucalyptus that soon becomes all and slender. It thrives best ncar the coast in southern California. 
The chestnut blight is a serious enemy of the chestnut and has caused havoc in the Eastern States. It makes the planting of the tree in the West a considerable risk, because of the chances of its attack by this disease. It made its appearance in this country in 1904, being brought in from either China or Japan, and has resulted in the death of a large number of chestnut trees in the East. So far as known, it has not attacked the few chestnut trees planted in California to any extent, but it must be taken into consideration in selecting chestnut for planting.

\section{SPANISH CHESTNUT}

The home of the Spanish chestnut (Castanea sativa) is the south and southwest of Europe, and on the slopes of the lower hills of Spain and Italy it is remarkable for its size and beauty. Pliny says that Julius Caesar introduced it into Italy from Sardis in Asia Minor, and that the Romans greatly appreciated the "Sardian acorn," as the nut was called. The chestnut probably grew wild in Greece where, as early as the fourth century B. C., Theophrastus, the Father of Botany, speaks of it as covering the slopes of Olympus.

Old chestnut trees often are made up of a fusion of many stems into one, which explains the enormous size of some of these trees. The "Chestnut of a hundred horses" on the east side of Mount Etna is 160 feet in circumference. It is entirely hollow, and has a kiln built inside it for drying chestnuts, which are a staple article of food in south Europe.

The chestnut was brought to England during the Roman occupation and is often referred to in accounts of early English deeds. Henry II, in granting land to the Abbey of Flaxley in the Forest of Dean, mentions the chestnut trees growing there. Shakespeare makes allusion to it in "Macbeth" and the "Taming of the Shrew," particularly to the use of the nuts for food.

The Spanish chestnut has been planted with success in various sections of California. The best known tree is the Hilgard Chestnut, which stands on the campus of the University of California in front of Agriculture Hall. It was named after Dr. E. W. Hilgard, the first dean of the College of Agriculture, foremost soil expert of his generation and one of the pioneers of agricultural education in the United States.

This tree was planted in 1885 and now is thirty-five feet high with branches spread over a circle about fifty feet in diameter. It has always grown in the 
open without interference from other trees, and is therefore low-branched with a wide spreading rounded, symmetrical crown. It is now forty-one inches in diameter at one foot from the ground, and at about four feet the trunk divides into cight spreading branches. In $\mathrm{M}$ larch, 1920, during the Agricultural "labor day" the students of the College of Agriculture gradect the area surrounding this tree and planted it to a variety of trees and shrubs.

In England the chestnut is a valuable avenue tree. Across an ordinary drive the trees will meet in a few years. The old trees are very picturesque. The thickness of the trunks and stoutness of the lateral branches well justify the description of Hamerton:

"His expression is that of sturdy strength, his trunk and limbs are built, not like those of Apollo, but like the trunk and limbs of 1 Hercules."

\section{COPPER BEECH}

The copper beech (Fagus syltatica purpurea) is a horticultural variety of the European beech which is cultivated for the striking color effect which it gives. Its foliage is purplish crimson at first, changing to a deep lustrous purple as the tree matures.

The beech of the Eastern States and of Europe is a large imposing tree which can be grown in its native habitat with very little attention. The forester looks upon it as "the mother of the forest" because of the protection it gives the soil besides enriching it with its fallen leaves. In California it cloes not do well except where it has abundant moisture and well-drained soil. The copper beech seems to be the best adapted to our conditions. It is a small tree which is chiefly fit for small surroundings and for contrast.

\section{CORAL TREE}

The coral tree (Erythrina crista-galli) comes from Brazil, where it is often used to shade coffee plantations. It sometimes develops a short trunk on which the flowering branches die back after blooming. The flowers are very beautiful, being very large and borne in panicles from one to two feet long. Their color is a brilliant crimson, shaded with scarlet.

This tree is very striking in a garden, but is very subject to frost even in southern California. It requires good soil and plenty of water during the summer months. It has a sun-loving nature and does not do well where sub- 


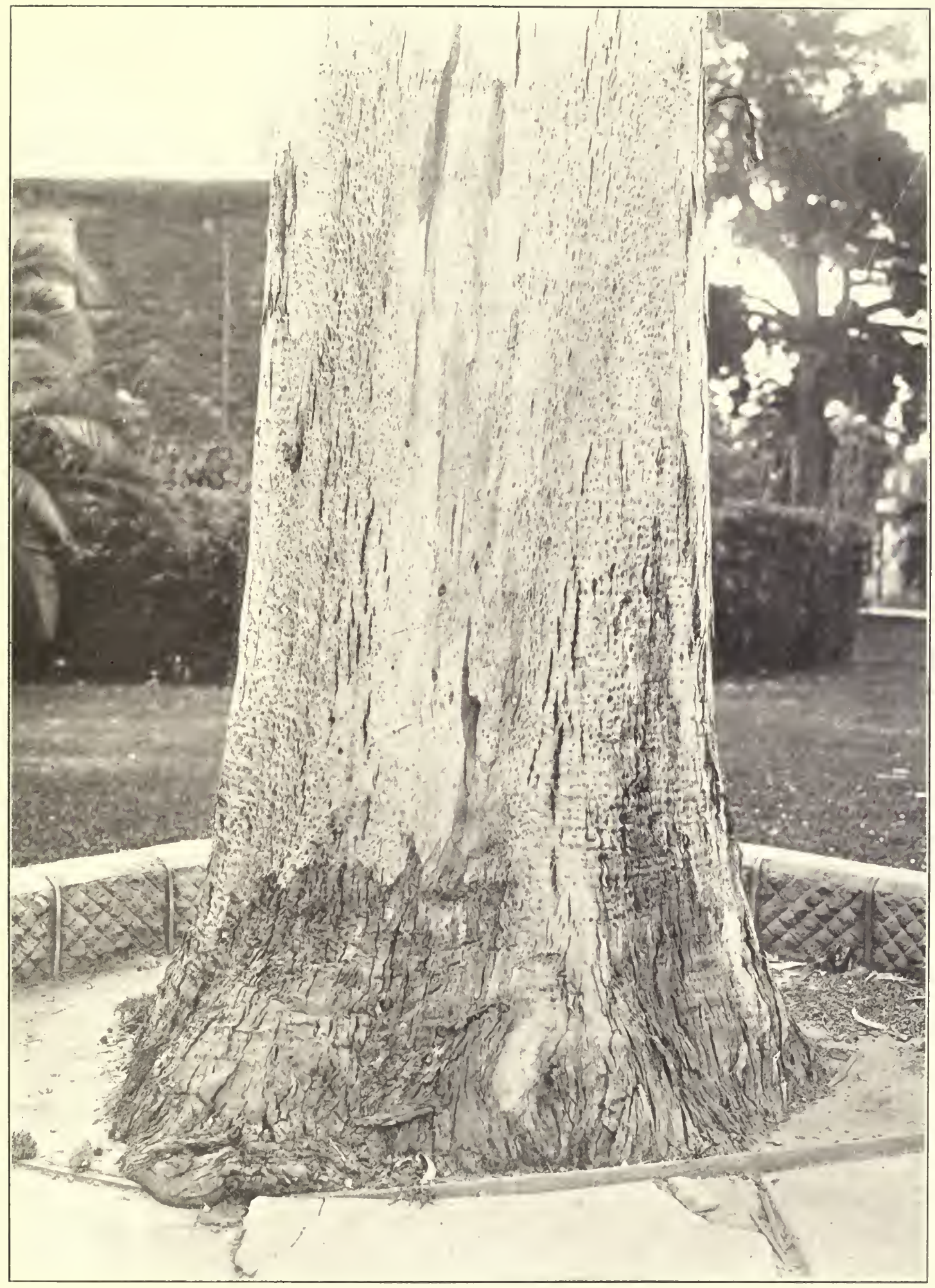

Plate 47. LEMON-SCENTED GUM TRUNK. San Diego.

One of the eucalypts which is unique for its smooth, ivory-white, tapering trunk and for its lemon-scented foliage. 


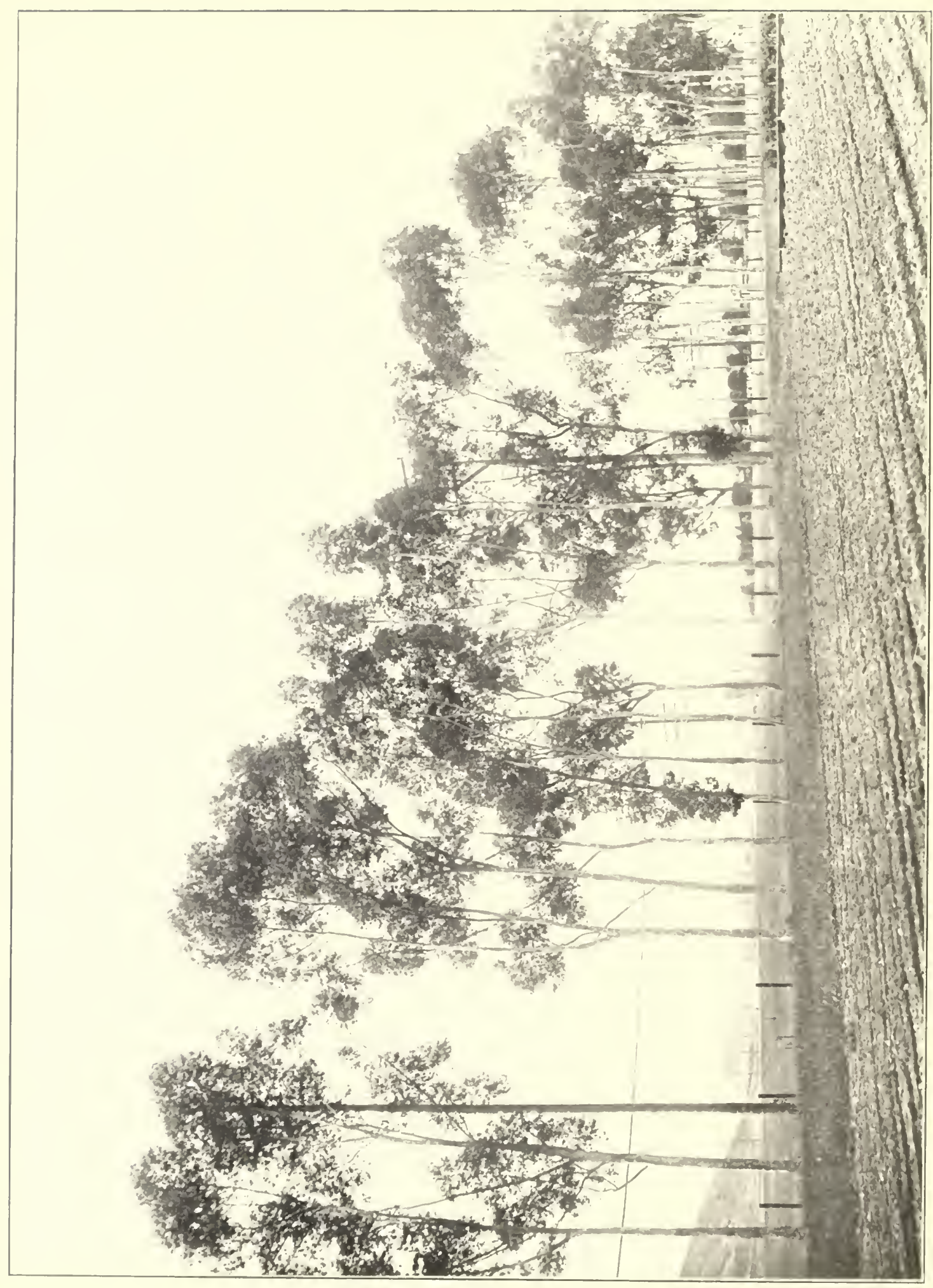


ject to the cool fogs of the coast. Its attractive trifoliate leaves and striking blossoms, however, make it a prized ornamental tree wherever it can be successfully grown.

\section{CRAPE MYRTLE}

Crape myrtle (Lagerstroemia indica) was given its generic name in honor of Lagerstroem, a Swede, and friend of Linnaeus. It is a small tree about twenty feet in height, which is generally considered as a shrub because of its slow growth. Its chief attraction are its showy flowers which vary in color from white to pink. It has small deciduous leaves and very smooth bark, which with its flowers makes it a favorite choice for central parkings where large trees would interfere with traffic, and where ornament is the chief consideration. It is hardy in all valley portions of the state.

\section{CHRISTMAS BERRY}

The Christmas berry (Photinia arbutifolia) is a distinctive California shrub which grows nowhere else in this country. All the other species, of which there are about thirty, are found chiefly in southern and eastern Asia. . It is the glory of our hillsides in fall and winter with its bunches of crimson-red berries in contrast with its glossy green foliage.

Many people think that the Christmas berry, commonly called California holly, is related to the English holly, which its leaves and berries closely resemble. It has no botanical relationship, but the spirit that prompts its use for decorations during the Christmas season recognizes no difference. Every year witnesses more people gathering "red berries," and in some sections of the state there is danger that this attractive shrub will become extinct because of the ruthless way in which it is treated.

It is stated by forestry officials in southern California that the Christmas berry in its canyons will become exhausted within three years unless commercial and individual gatherers stop pulling the bushes up by the roots. Commercial gatherers are said to be picking it by the ton to be made into wreaths that retail at a dollar apiece.

So destructive has been the gathering of holly in San Mateo County that arrests have been made for trespass by owners as the only recourse of stopping the vandalism practiced. People who would not think of going into 
private grounds and chopping down an ornamental shrub, think nothing of uprooting a holly hush, one of the most beautiful of nature's ornaments.

If the Christmas berry is to be preserved it must be given a chance to renew itself from year to year. This it will do if only small lateral branches are cut off with a knife or pruning shears. The main branch system should not be mutilated since wouncls cause it to be subject to diseases such as the pear-blight, which will eventually kill the shrub. The removal of lateral branches does not affect its health. Vandalism will mean the exhaustion of the California holly even as the arbutus of the Eastern States was destroved by ruthless hands.

The native Christmas herry thrives under cultivation and with good care grows quickly. I Chinese species (Photinia serrulata) is a fine shruh which often reaches a height of twenty feet. It has long drooping leares which are very lark green and glossy on the upper surface. Some of the leaves turn a vivid red in the fall and persist during the winter. Small, white flowers in large heads are borne in great profusion followed by showy berries. This shrub is very hardy and is a favorite because of the fine ornamental effect which it gives.

\section{DOGWOODS}

The dogwoods are shrubs or small trees that are grown for their attractive flowers and fruits. The name logwood comes from the fact that a decoction of the bark of one of the species was used in England to wash mangy dogs. The generic name Cornus is from the Latin cornus and has reference to the horny texture of the wood.

The mountain dogwood (Cornus nullallii), a deciduous native species, is one of the finest for ornamental planting. In favorable situations it grows to a height of about fifty feet, and in early May, when entirely covered with great white bracts, it is most attractive. In the fall, when laden with orangecolored fruit, it gives good effects in shrubberies.

The evergreen dogwood (Cornus capitata) from the Himalayas is a splendid shrub which reaches a height of about fifteen feet. The flowers are large and cream-colored, followed by large, red, showy fruits. It is a rare plant at present, but on account of its hardiness and beauty, will be widely grown when better known. 


\section{ELMS}

The elms belong to the genus Ulmus, a Latin word which carries a reference to an instrument of punishment, probably because slaves were commonly whipped with rods of elm. There are about eighteen species distributed through the colder and temperate regions of the northern hemisphere. Few of our trees have a wider distribution. The elms are mostly tall trees with medium sized leaves, and small greenish brown flowers that appear mostly before the leaves. They have graceful outlines and luxuriant foliage which gives them a dignified and courtly appearance. They are often called the aristocrats of trees.

The Wych elm of England used to be considered a preservative against witchcraft, and a branch was put in a churn to prevent the cream from being bewitched and the coming of the butter hindered. The forked branches of the tree were used as divining rods, and riding switches from it were supposed to insure good luck on a journey.

Early English peoples worshipped their heathen deities in elm groves which led the Saxon King Edgar to issue the following decree:

"We decree that every priest shall anxiously advance Christianity and forbid tree-worship, divination with the dead, omens, chorus with songs, and many other illusions which are practiced in asylums on Elms and on various other trees, by which many are perverted who ought not to be so."

The American elm is closely associated with early colonial history. In "The Autocrat of the Breakfast Table," Oliver Wendell Holmes characteristically describes it:

"The American elm is tall, graceful, slender-sprayed, and drooping as if from languor. The English elm is compact, robust, holds its branches up, and carries its leaves for weeks longer than our own native tree. Is this typical of the creative force on the two sides of the ocean, or not?"

English people used to gather under elms on the village greens to debate public questions. This old custom probably led the early settlers in New England to plant elms in their dooryards and on the village greens, and to regard them as symbols of liberty. Liberty Elms were planted in Boston,

$5-11598$ 
Providence, Newport and Xew York. The Providence elm was dedicated to the "Sons of Liberty" on July 25, 1768, in words which were in part as follows:

"lle do, in the name and behalf of all true sons of liberty in America, Great Britain, Ireland, Corsica, or wheresoever they may he dispersed throughout the world declicate this tree of liberty"****. When they look toward this sacred elm may they be penetrated with a sense of their duty to themselyes and their posterity, and may they; like the house of David, grow stronger, while their enemies, like the house of Saul, shall grow weaker and weaker."

A few years later on July 3, 1775, George llashington assumed command of the Continental Army under an elm at Cambridge, Mlassachusetts.

The "Treaty Tree," under which William Penn concluded a treaty with the Indians, was an elm. This tree, which was destroyed by a storm a century ago, has been immortalized in the famous painting by Benjamin Itest.

\section{AMERICAN ELM}

American elm ( I lmus americana) is a striking tree at all seasons of the year. In the winter its graceful limbs stand out against the sky. In the spring it is one of the first trees to blossom. Tiny reddish-brown blossoms appear, shortly followed by the fruit, which is surrounded by flat, oval-shaped wings which later help to scatter it from the parent tree. The fruit matures about the time the leaves begin to unfold and when summer comes the tree rises like a great fountain of brilliant green.

New England is noted for its magnificent elms which were planted by the early settlers. New Haven is known as the Elm City because of the many stately elms that line its streets. Connecticut is noted for its elms, the largest being the Wethersfield Elm in Hartford County. This tree, which is 250 years old, is ninety-seven feet high and has a circumference of twenty-eight feet and a branch spread of 147 feet. On the White House grounds at Washington stands a noble elm planted by John Quincy Adans when he was President.

New Englanders brought the elm with them to the Middle West, where many of the towns and cities have their streets lined with this beautiful tree.

Indiana's most famous tree is the Constitutional Elm, located at Corydon. On June 10, 1816, members of the Constitutional Convention met beneath 


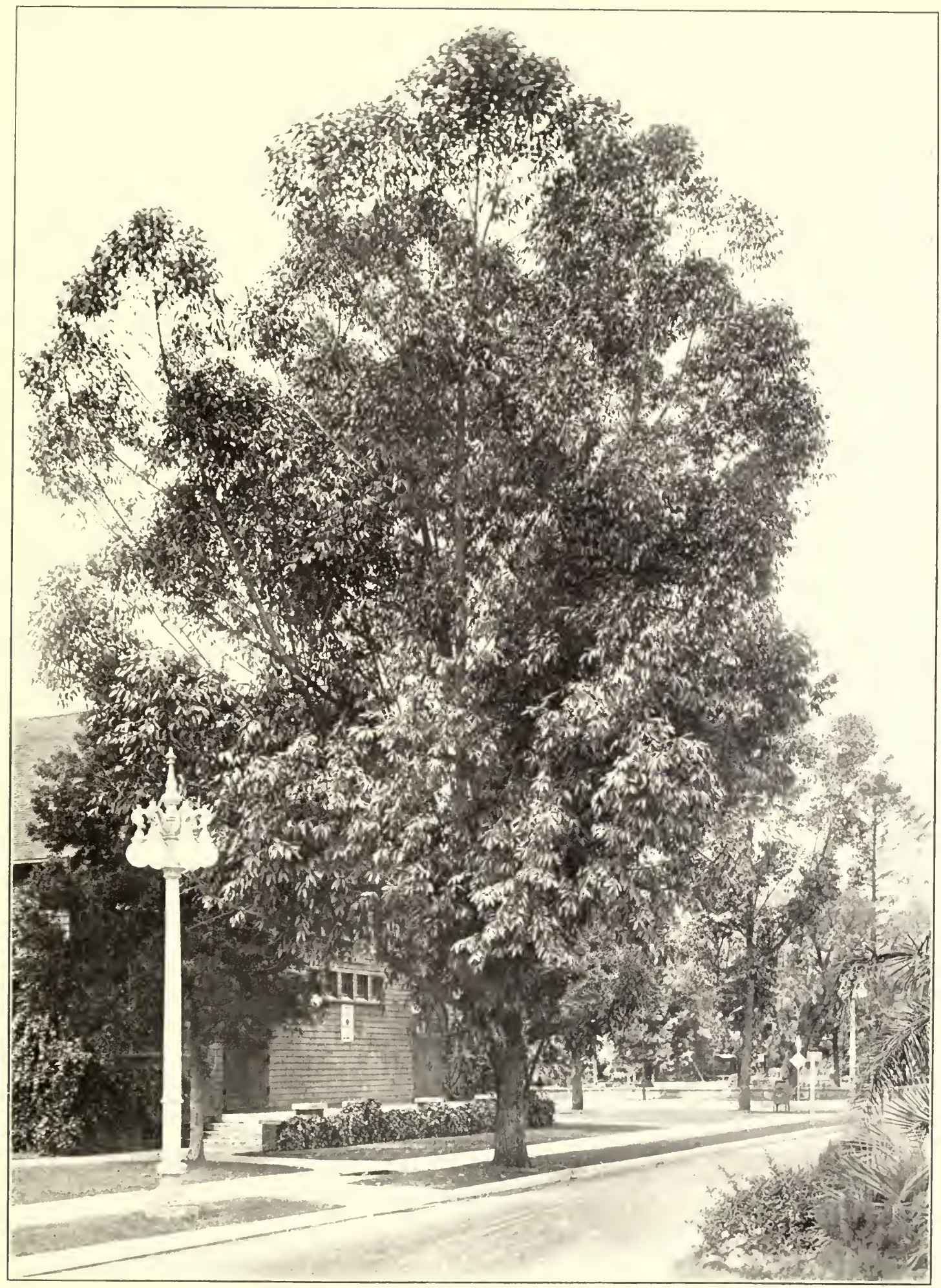

Plate 49. SWAMP MAHOGANY, Los Angeles.

This species of eucalyptus has been widely planted a; a street tree because of its symmetrical growth, white flowers and glossy foliage. 


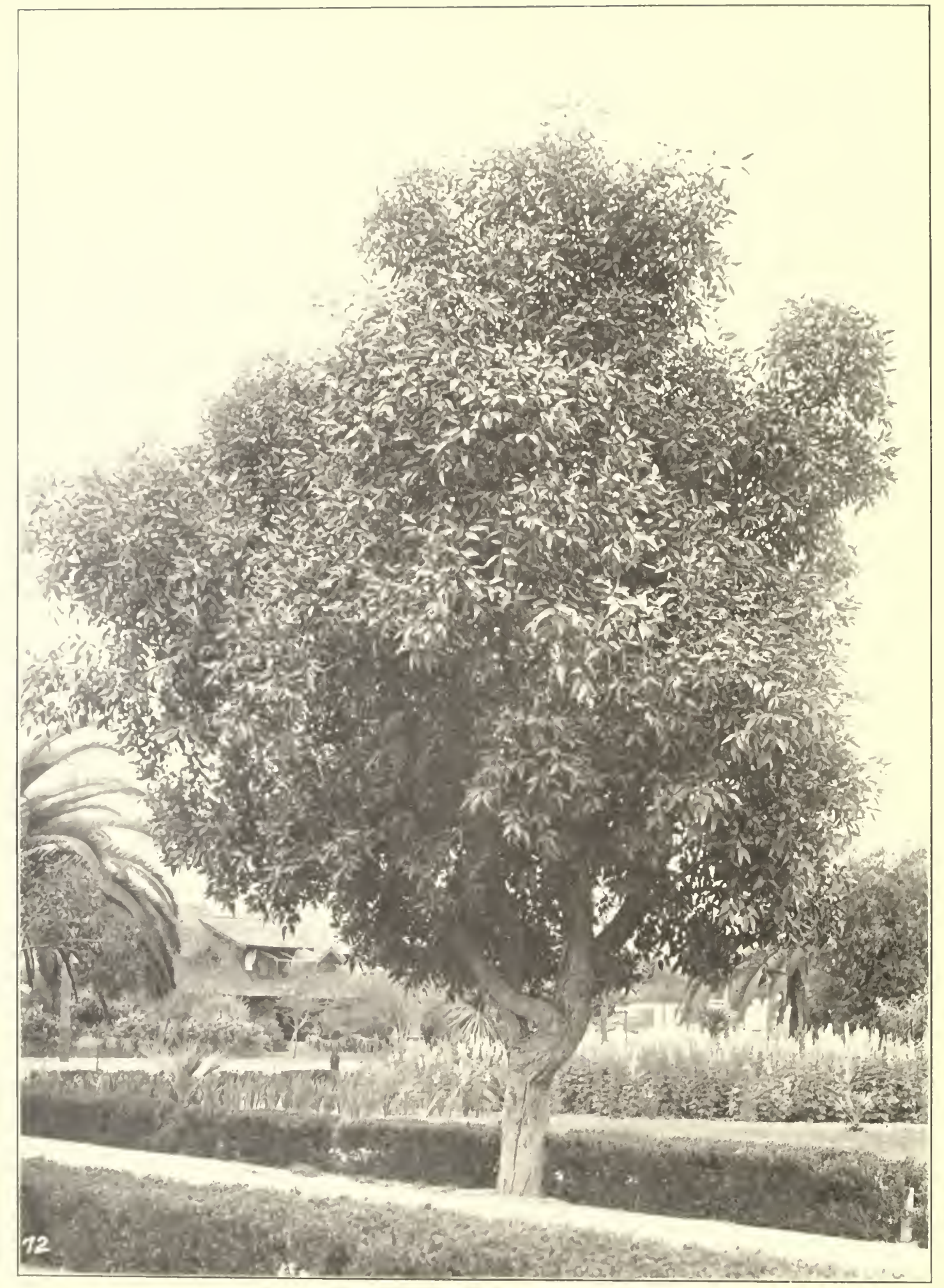

Plate 50, SCARLET-FLOWERING GUM. Pasadena.

One of the nust ornamental of the eucalypts because of tts lasce, leathery leaves and handsome crimson flowers. 
this tree, which is a few hundred feet from the first State House. This tree now has a spread of 124 feet.

Thanks to the foresight of some of her early settlers, some of the cities in northern California, notably Sacramento and Chico, have many stately specimens on their streets. Had these pioneers planted rapid growing but short lived trees like poplars or soft maples there would now be straggling, dying trees instead of picturesque old elms forming Gothic archways like cathedral naves.

With all its advantages, the American elm has some objectionable features, such as its suckering habit and its susceptibility to the attack of insect pests. It does not appear, however, to be as badly attacked by pests in California as in the Eastern States, where the gypsy moth, brown-tail moth and elm-leaf beetle are causing so much trouble. Its chief enemies in this state are aphids. This pest does not attack the English elm to any extent, which often leads to its choice over the American elm.

The value of shade trees such as the elm can hardly be estimated. Not long ago a well known landscape architect, who had charge of laying out one of the most famous estates in America, was asked how much a certain tree was worth. "Worth," he said emphatically, "It is worth the whole place, for it is creative of beauty, and around that tree I build everything."

Only recently the Bronx Parking Commission in New York City went to the heavy expense of constructing protective channels for the roots of a large elm tree in order to relieve them from pressure from a thirty foot retaining wall which otherwise would have caused the tree to die.

\section{ENGLISH ELM}

English elm (Llmus campestris) has a smaller and more rounded head than the American elm, and retains its foliage later in the season. It is a favorite tree in England where it is widely planted. The famous "Long Walk" in Windsor Park is lined by this handsome and imposing tree which Boulger well describes in the following words:

"When bare of leaves, and standing black against a dull wintry sky, the tiny twiglets on the topmost boughs appear as delicate lacework, far exceeding in fineness the minutest ornament of the Gothic architect, and yet graduating downwards into mighty beams, so as to suggest at once the strength of Nature's framework and the delicacy of her finish." 
The eighteenth of April is termed Ulmifrondes in the south of England, for then the tree is generally in full foliage. In August and September, when other trees are changing hue, the English elm retains its sombre green foliage, and it is not until after all its neighbors have shed their leaves, that its leaves hegin to fade and fall.

When planted in California the English elm makes an erect, rapid-growing tree, which is remarkably free from the insect pests so common to the American elm. It stands trought well, and because of this quality as well as its long life, neatness and symmetry, is an excellent tree for street and highway planting. Its chief objections are the suckers which spring in great abundance around the hase of the trunk. Browning refers to them as "the brush-wood sheaf round the elm tree bole.

\section{HUNTINGTON ELM}

The Huntington clm ( L lmus glabra regeta) is a hybrid elm of erect habit and rapid, rigorous growth. The large green leaves make a dense foliage which is very attractive: This elm is excellent for street and highway planting because of its resistance to drought and insect enemies.

\section{EMPRESS TREE}

The Empress tree (Paulownia imperialis) takes its generic name after Anna Paulownia, a Russian princess. It is a native of China and greatly resembles the catalpa, the chief difference being in the shape of the pods. It reaches a height of about forty feet and has stout spreading branches which form a round head. The heart shaped leaves are large and tropical looking. The lavender flowers, which resemble those of the foxglove, appear in large terminal panicles followed by pods that remain on the tree during the winter. This tree is adopted for semitropical effects and makes a good growth on fertile soil. It is very subject to sunburn, however, and should be planted where it will be well sheltered.

\section{EUCALYPTUS}

The genus Eucalpytus, which is native to Australia and the Malayan region, embraces about 300 species, one hundred or more of which have been introduced into California. The name is derived from the Greek words $\mathrm{eu}$, meaning well, and kalypto, to cover as with a lid. The last term has reference 


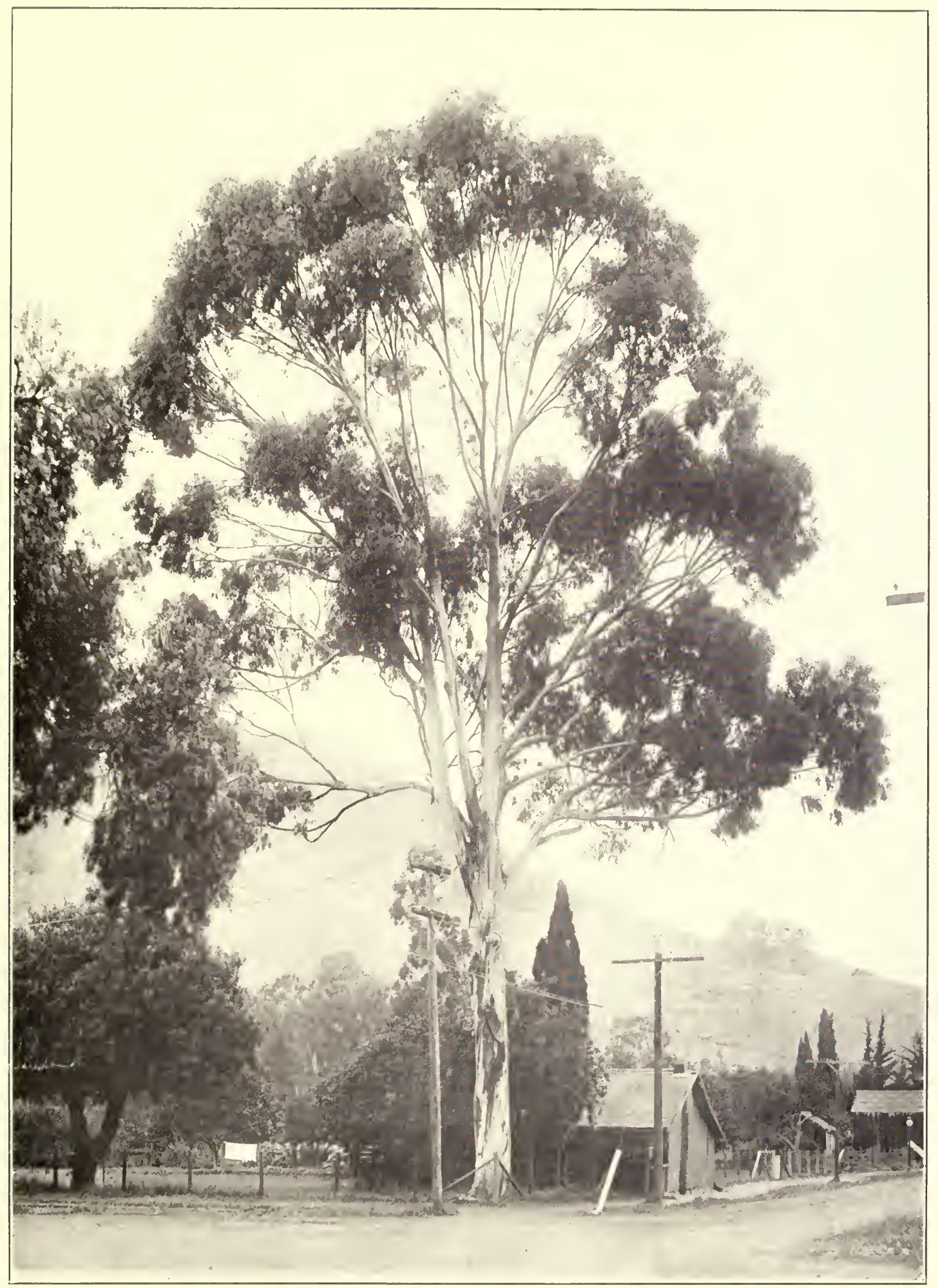

Plate 51. BLUE GUM. San Luis Obispo.

Its light bluish-green foliage gives this tree its common name. It is the best known species of cucalyptus in California and grows rapdly in favorable situations. 


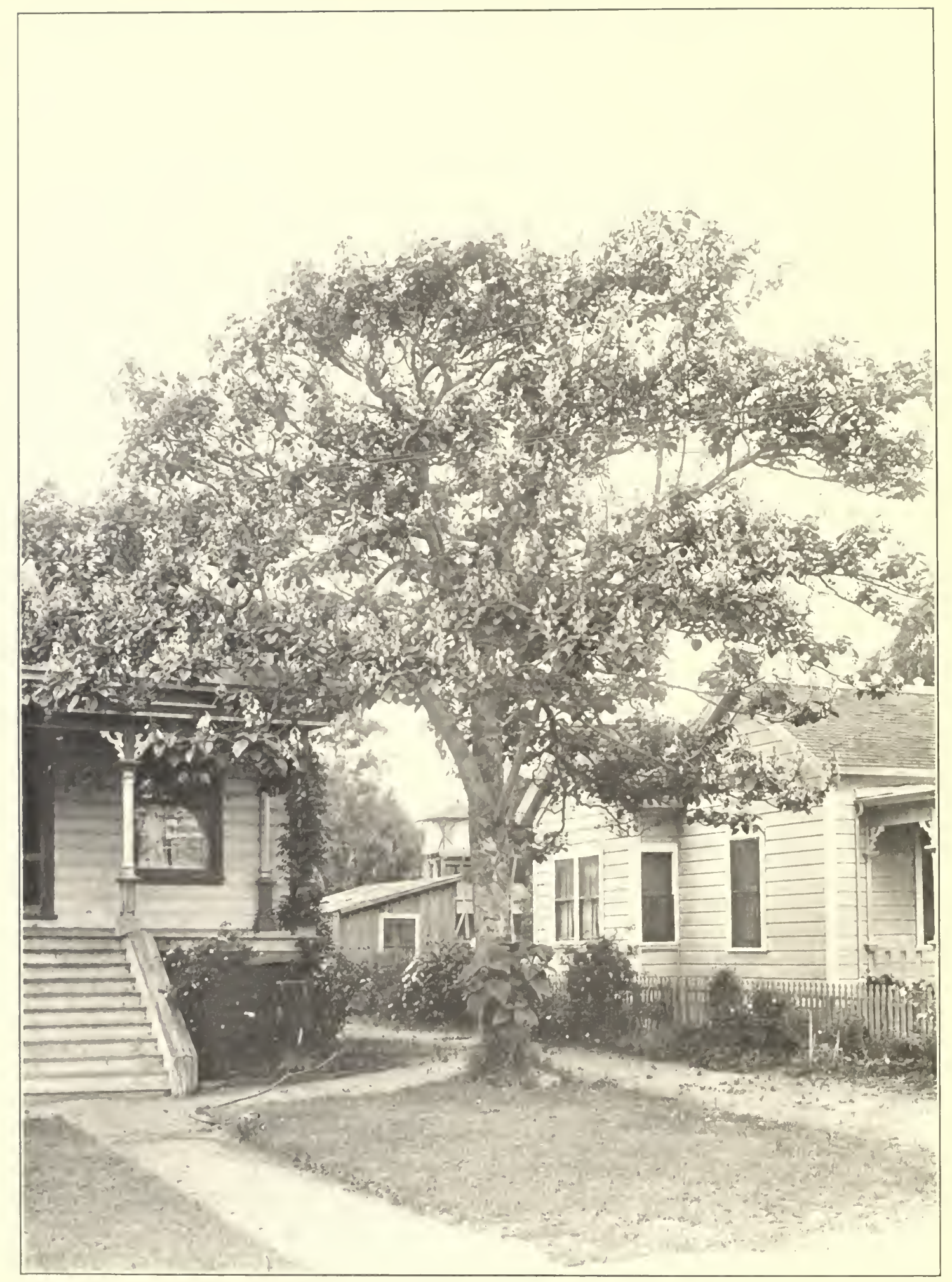

Plate 52. EN PRESS TREE. San Luis Obispo. 
to the conical, lid-like covering of the buds which falls off before the flowers open. Most of the eucalypts secrete resinous gums, hence they are commonly known as gum trees.

Eucalyptus has been established successfully in semitropical and temperate regions all over the world. It is frequently planted in the malarial regions of warm climates, as at the Campagna at Rome, to drain the swamps which give rise to malaria, but its greatest value is for ornament, shade, windbreaks and fuel. In Australia it is extensively cut for lumber, but it has not been generally successful in this country for that purpose on account of the checking which takes place in seasoning due to the high water content of the wood.

Eucalyptus was introduced into California in the early fifties by travelers who were impressed with its rapid development in its native habitat. The first plantations were around San Francisco Bay and in the Santa Clara Valley. About i 865, Mr. Elwood Cooper set out large plantations on his ranch near Santa Barbara. Since that time it has been extensively planted in various parts of the state as ornamental and shade trees.

It was early found that all species were sensitive to frost although a few species will endure temperatures as low as eighteen degrees Fahrenheit without injury. In general, eucalyptus can be successfully planted in all sections of the state suitable for the culture of citrus fruits. Under favorable conditions the trees reach a large size in a short space of time.

All species of eucalypts have evergreen leaves, and for this reason are not as desirable for highway planting as deciduous trees, because they hinder the road-bed from drying. In addition, the strong development of the roots impairs the fertility of adjoining land. For this reason many rows of eucalyptus trees bordering citrus groves in southern California have been cut down. There are many locations, however, where the eucalypts find favor in spite of these objections because of the fine effect which they give, and because of their value for fuel. Many of the eucalypts sprout prolifically when cut and produce firewood at a rapid rate, at the same time providing ornament and shade.

Because of the many species of eucalypts found in the state, no attempt is being made to consider them all in this publication. Only those are given which appear preferable for shade and ornamental purposes. 


\section{BLUE GUM}

Blue gum (Eucalyptus globulus) is the best known species in California, and derives its name from the light bluish-green color of its juvenile foliage. It is probably the fastest grower of any of the eucalypts. In Australia the usual height is over 200 feet. In California trees thirty years old have attained the height of 150 feet and a diameter of from three to four feet under good soil and moisture conditions.

Blue gum reaches its best development along the coast and river bottoms where moisture is plentiful and fogg! days frequent. It is frequently found in the towns of the Sacramento and San Joaquin valleys, however, and endures frost as far north as Tehana County.

Individuals of this species grow straight as a rule and develop handsome, globular heads. On old trees, the leaves are elongated, sickle-shaped and dark green on both sides. The white flowers which appear from January to M lan give rise to a dark green valve shaped fruit.

Nlthough blue gum is a beautiful tree, its size makes it unsuitable for street planting because of the damage which it eventually does to curbs and sidewalks and the invasion of sewers by its roots. It is best adapted to wide boulevards where it can develop without interfering with adjoining improvements.

\section{RED GUM}

Red gum (Eucalyptus rostrata) is almost as fast a grower as blue gum and has the advantages of being able to stand more cold in its youth as well as more drought. This makes it a good choice for interior sections where there is considerable range in temperatures. Its chief objection is that it does not tend to grow erect even in close plantings.

The twigs of old trees have a reddish hue, and the trunks are clark gray, and the head broad. The leaves are elongated and narrow, and the white flowers which appear in May and June are borne in clusters. Red gum attains considerable size under a wide variety of soils even when some alkali is present, and forms a large percentage of plantations in the northern part of the state.

\section{MANNA GUM}

Manna gum (Eucalyptus viminalis) is a handsome tree with long pendulous branches which makes it picturesque for boulevard planting. The bark is 


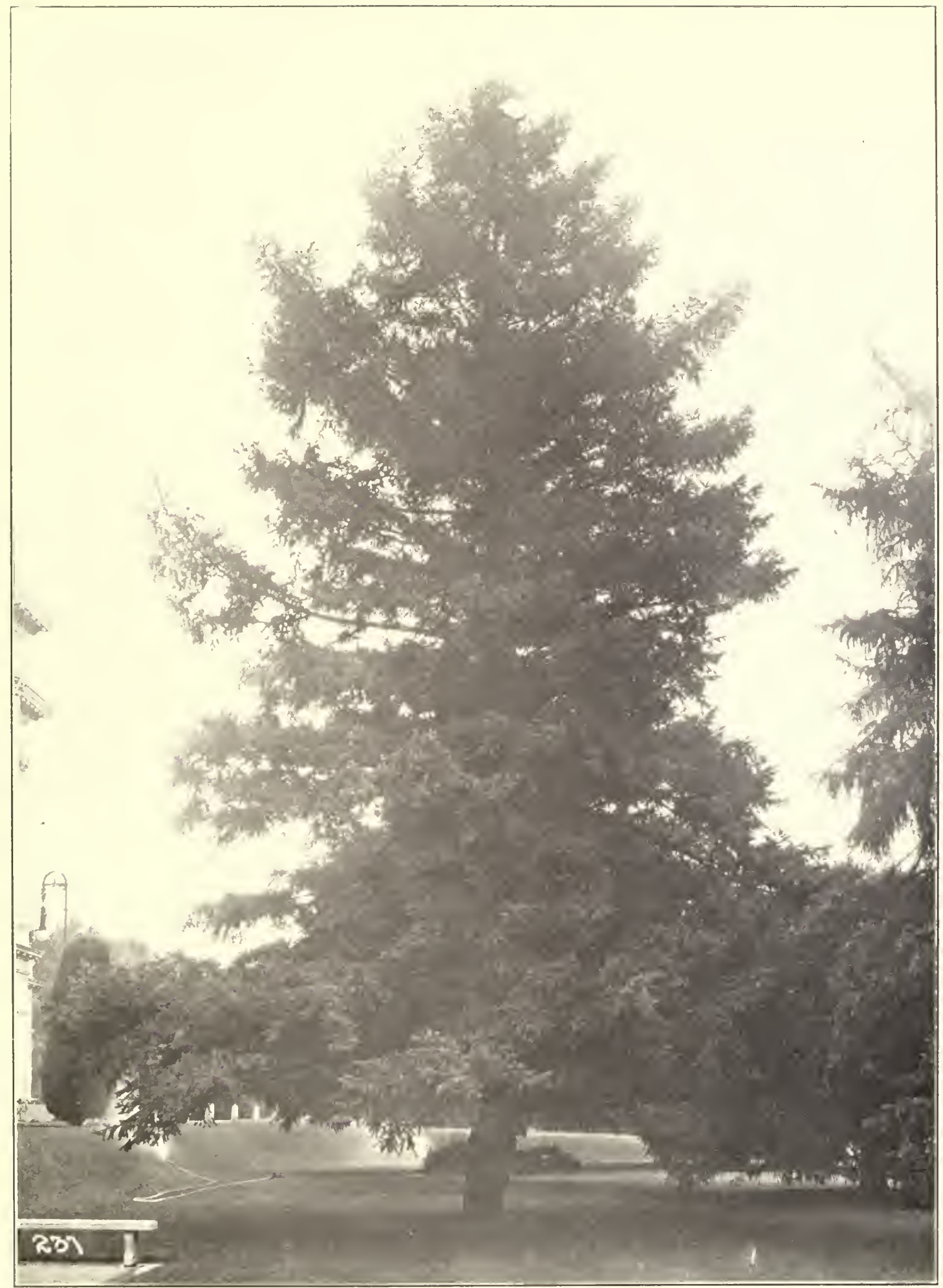

Plate 53. DOUGLAS FIR. Sacramento.

An important western timber tree that has value for ornamental purposes because of its rapid growth and soft, dark green foliage. 


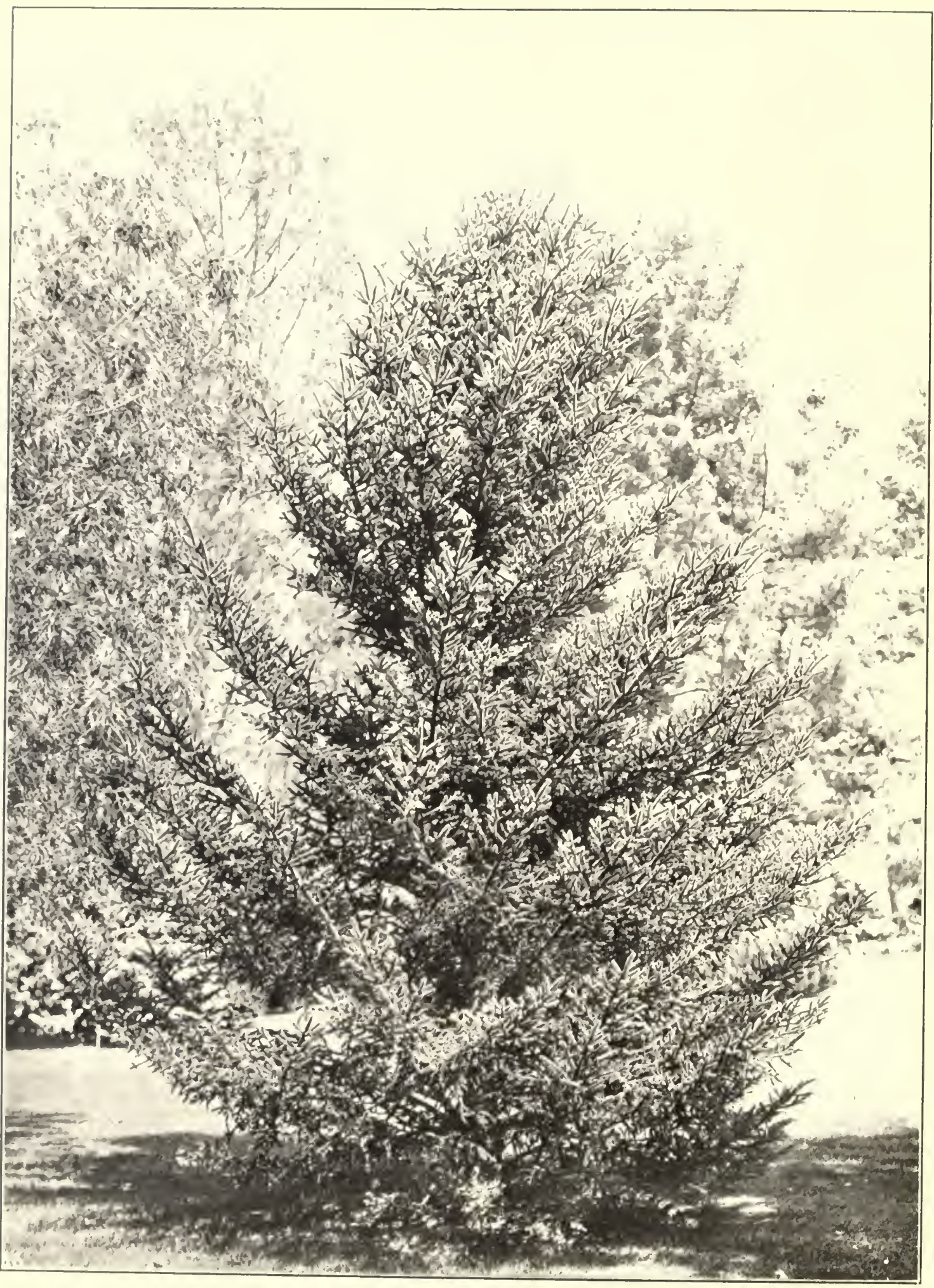

Plate 54. SPANISH FIR. Burlingame. 
shed each year at the blooming period of the tree. It will thrive under a variety of conditions, but prefers a deep, well-drained soil. The species is widely planted in the San Joaquin Valley. There is a tree near Reedley in Tulare County on which records have been kept since it was planted in 1889 . The last measurement taken in 1916 gives the height of this tree as 130 feet and the circumference as twenty-three feet at three feet above the ground.

The manna gum stands as low temperatures as the red gum and blue gum and is found in a flourishing condition in the vicinity of Chico. Its chief objection is the shedding of the bark.

\section{LEMON-SCENTED GUM}

Lemon-scented gum (Eucalyptus citriodora) is unique for its smooth, ivory white, tapering trunk and for its lemon-scented foliage. It has an erect habit of growth and its drooping branches with their long, narrow leaves give it a weeping effect which makes it attractive as an ornamental.

This species is limited to the warmer parts of the state because of its inability to stand much frost. Some fine specimens are found in San Diego and Los Angeles. It requires a fairly good well-drained soil for best results, but will grow on any tillable soil free from alkali.

\section{DESERT GUM}

Desert gum (Eucalyptus rudis) is a medium-sized tree from seventy-five to one hundred feet in height with a rough, persistent bark and a drooping branch habit. It grows erect and the oval shaped foliage is thick and strongly scented. It is one of the best of the eucalypts for street planting because of its compact habit and persistent bark. Its name is given it for its hardiness in irrigated sections of the desert.

\section{SUGAR GUM}

Sugar gum (Eucalyptus corynocalyx) reaches its best development in the southern part of the state. In the interior valleys it has not proven frost resistant. It is very resistant to drought and hot winds, and thrives equally well on the coast and in the southern interior valleys.

The bark, which flakes off on older trees, varies in color from a cream to a dark gray. The leaves are ovate, dark green on the upper side and lighter in color beneath. The growth is erect with a symmetrical, well balanced crown. 
It is widely used as a street tree at San Diego and for wind breaks near Riverside and San Bernardino. It tends to become straggling with age.

\section{SCARLET-FLOIVERING GUM}

Scarlet-flowering gum (Eucalypus ficifolia) is an ornamental species with large, leathery. way-margined leaves and handsome crimson flowers. It is of slow growth and is well adapted for streets where there is no danger of injuring the sidewalks with its roots. It is a commonon ornamental tree in the southern part of the state and a very fine hones producing plant

\section{WHITE IRONBARK}

White ironbark (Eucalyptus leucoxylon) is a fairly tall tree which branches well down the trunk. The deciduous bark of the old trees varies from a cream to a very dull gray. This species reaches its greatest development along the coast and localities where there is plenty of rain, but will withstand drought conditions at temperatures of fifteen to twenty degrees Fahrenheit. A variety "rosea" of this species has beautiful pink flowers, and can be grown in localities where the scarlet-flowering gum will not thrive.

\section{AUSTRALIAN BEECH}

Australian beech (Eucalyptus polyanthema), commonly called the "red box," varies from a small to a large sized tree. The bark is rough and persistent and the foliage has a distinctive gray-green color. It grows near the coast, but will do well in the interior. It has considerable ornamental value because of its round leaves of silvery lustre, and has small white flowers which occur in large clusters.

\section{SPOTTED GUM}

Spotted gum (Eucalyptus calophylla) is a moderate sized tree which thrives in most instances near the coast. It is one of the most ornamental species with its large glossy leaves and large white flowers, which are valuable for bees. It is easily affected by frost and does not do well except in southern California.

\section{EUGENIA}

The name of the genus Eugenia is in honor of Prince Eugene of Savoy. It includes a läge number of shrubs and plants mostly from the tropics, including the trees that produce the allspice and clove of commerce. 


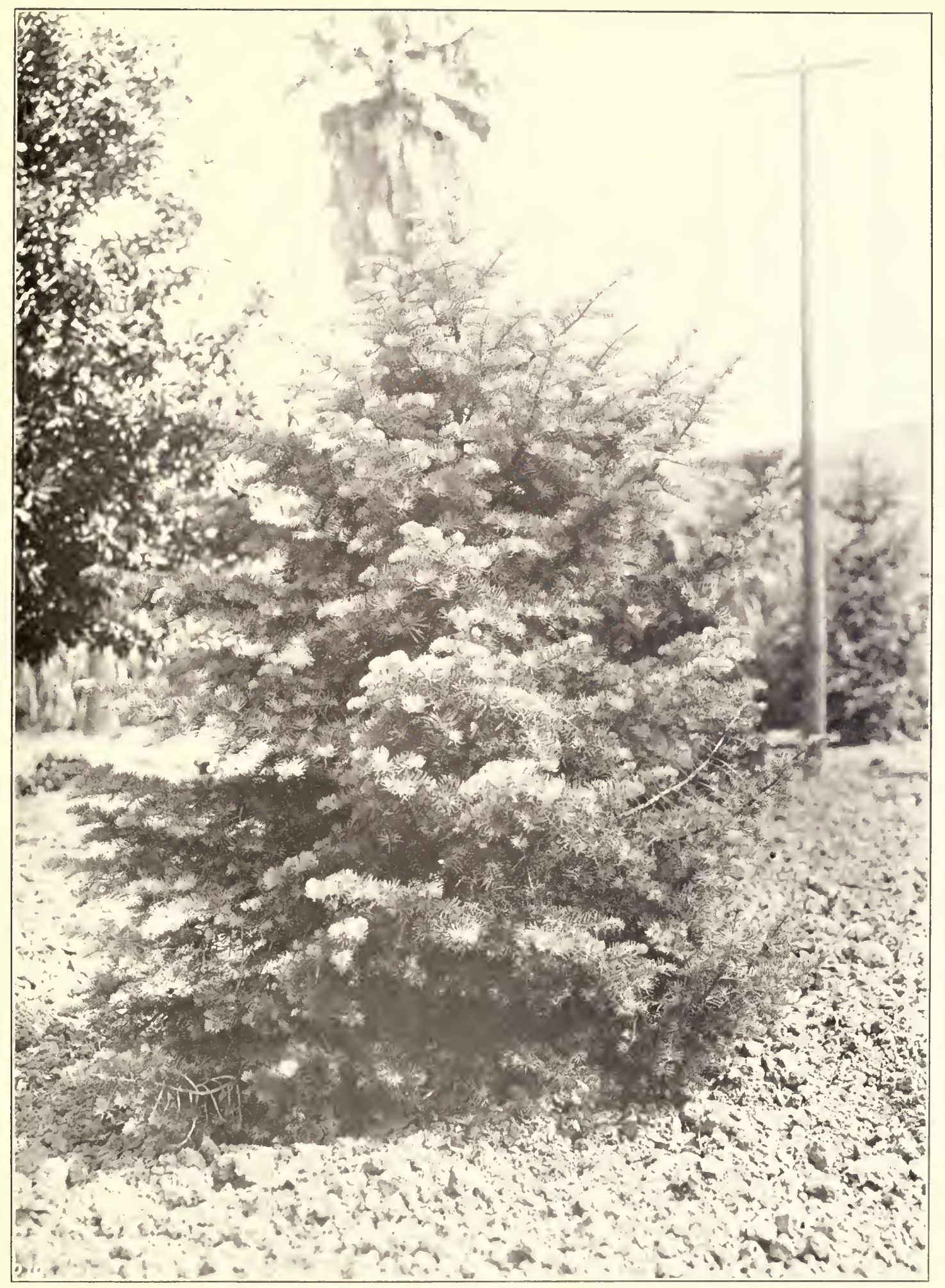

Plate 55. WHITE FIR. Niles.

A fir common to the Sierras of California. It is oftel called "silver fir" because of its ashy-grey bark. It has a very regular and symmetrical growth. 


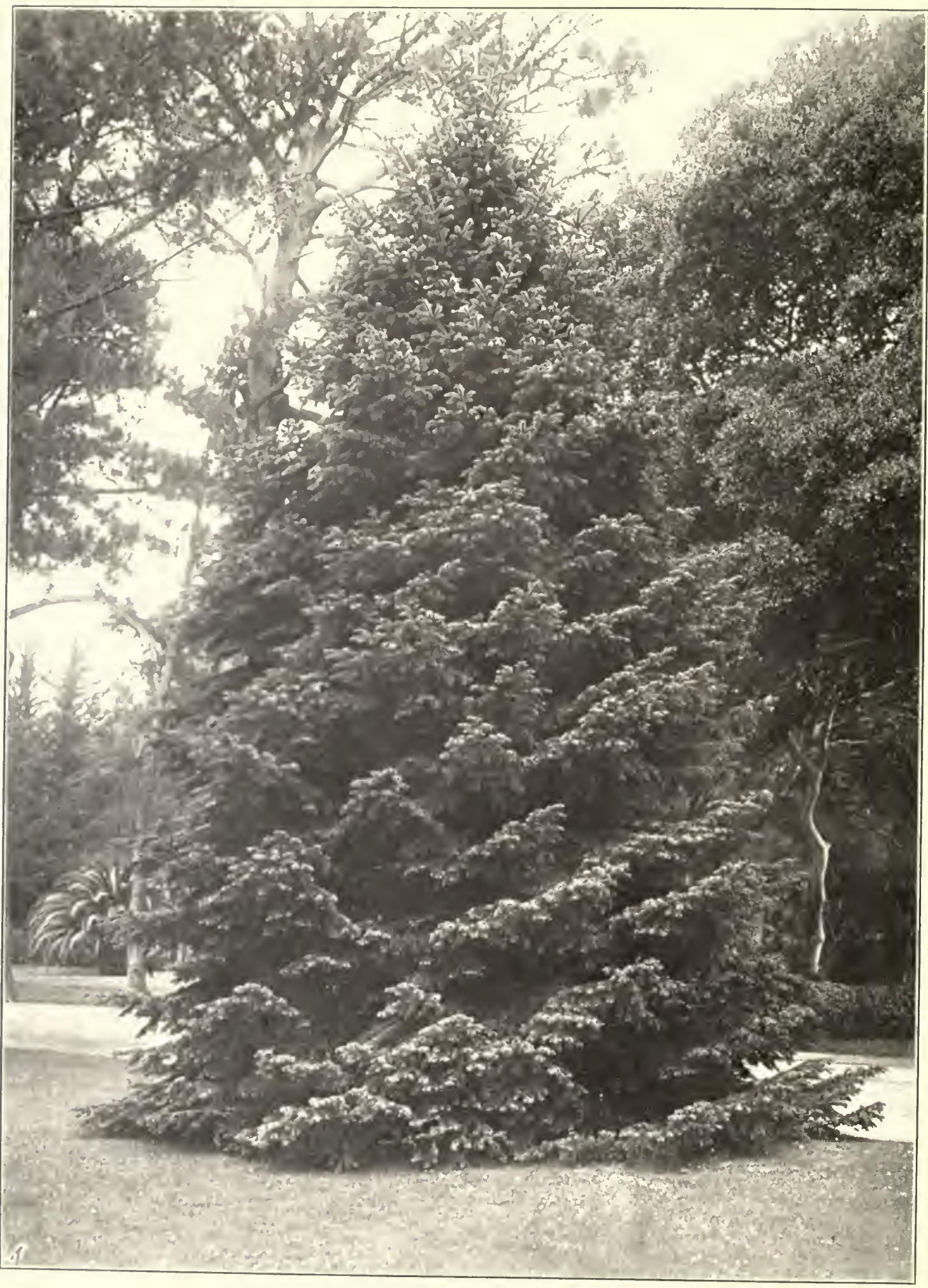

Plate 56. NORDMAN'S SILVER FIR, Del Monte. 


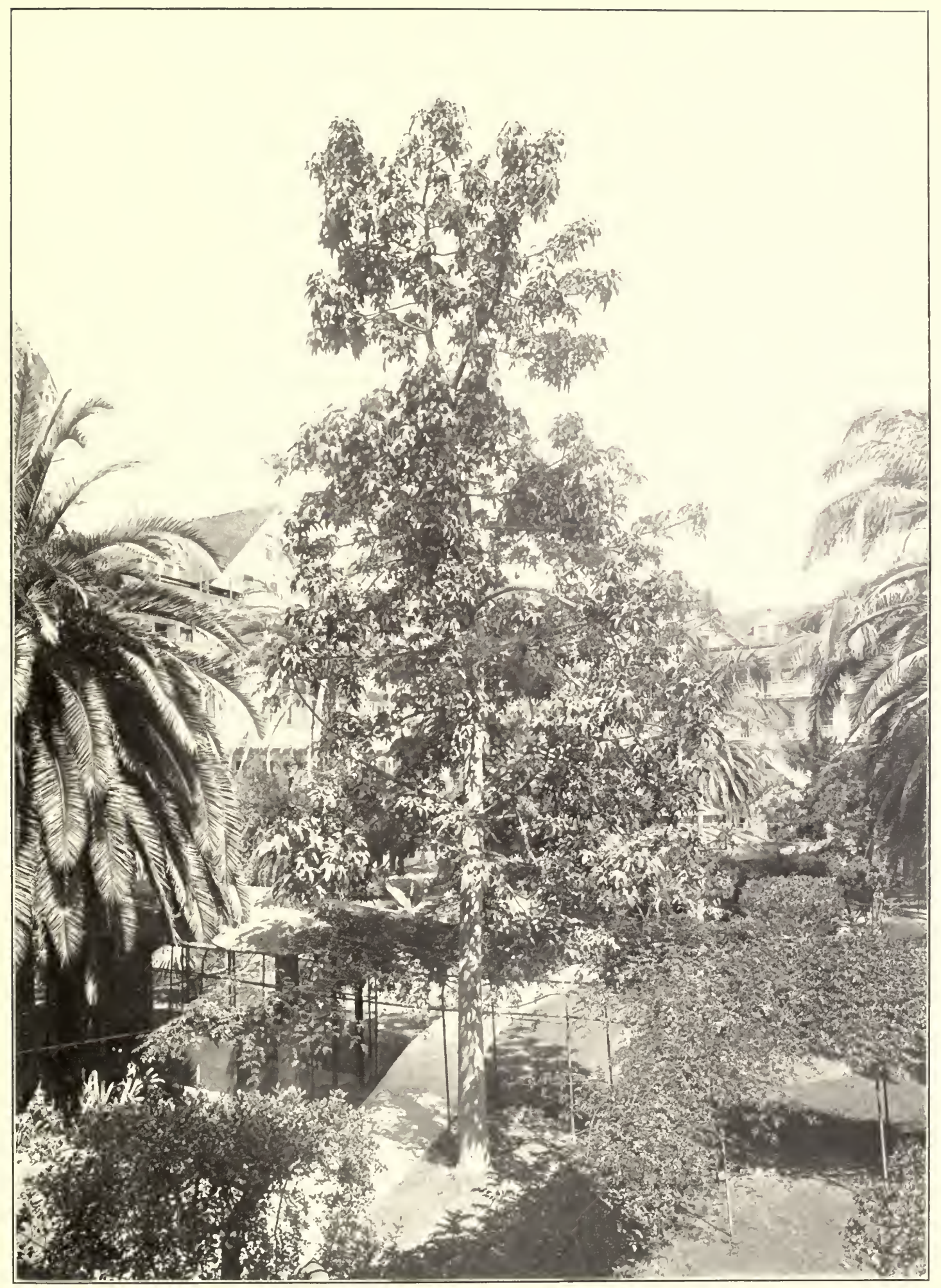

Plate 57. FLAME TREE. Coronado.

A tree from Australia that takes its name from its scarlet flowers which are produced in showy clusters. 


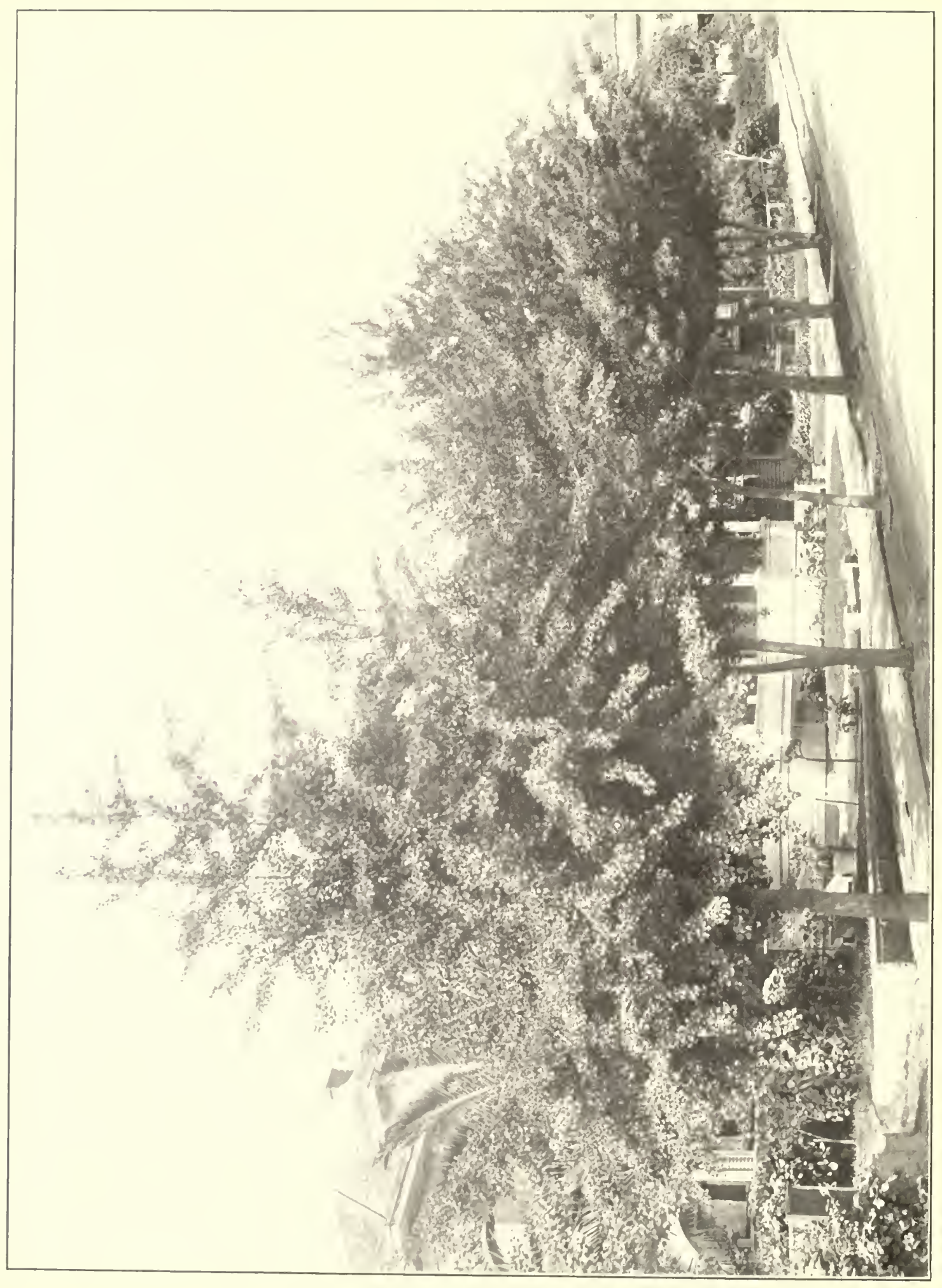


The Australian brush cherry (Eugenia myrtifolia) is probably the best species for planting in this state, since it can be grown as a shrub or tree. lt is a small evergreen tree with many myrtle-like glossy green leaves. The young foliage shoots are red and form a pleasing contrast with the older leaves. The myrtle-like blossons, which are creamy in color, occur in profusion, followed by reddish globular-shaped fruit. The form of this tree is columnar and the growth is fairly rapid. In southern California a height of forty feet in twenty years was reached by one tree noted at Coronado. Eugenia stands pruning well and is often planted close together to form tall, narrow hedges. It should make a splendid street tree in most parts of the state where the frosts are not too severe, because of its many admirable qualities. It is particularly adapted to narrow streets where heavy shade is not desired. It sometimes is defoliated by cold north winds so should be used with caution in exposed places.

\section{GOLDEN CHAIN}

The golden chain (Laburnum vulgare) is one of the most ornamental of small trees. It is a native of the mountainous woods of Central Europe which it graces with its smooth, shiny leaves and long pendent racemes of yellow "golden chain" flowers.

All the green parts of the tree are poisonous, which was known to Pliny, who stated that the bees never touched its blossoms. The wood is tough and hard and was used for bows by the ancient Gauls.

The golden chain grows erect and reaches a height of twenty to thirty feet. It has an irregular picturesque head, smooth olive-green bark, and small clover-like leaves. The hanging clusters of fragrant golden blossoms which are set so thickly upon the tree that the foliage is well-nigh hidden, are the chief charm of the tree.

This tree is adapted to small lawns or borders of shrubbery where it should be allowed enough space to show its golden blossoms as a contrast to the darkgreen foliage. It thrives on well-drained soils, particularly in the southern part of the state. An interesting feature of this tree is the expelling of the seed from pods on dry days with considerable force and a noticeable crackling noise. 


\section{HAWTHORNS}

The hawthorns belong to the Rose tribe and owe their name Crataegus (from the Greek, kratos, strength) to the density and strength of their wood. The genus includes more than one hundred and fifty species, which have a northern range in Europe. Asia and \orth America.

Hawthorns are among the most showy of the smaller deciduous trees due to their foliage, flowers and fruit. The deep glossy green foliage holds its color until late in the fall when it turns to various brilliant autumn colors. The flowers, which are white, pink and scarlet, are double and rose-like in some species. The fruit is apple-like, yellow or red, and hangs late into the fall. Nost of the hawthorns are spiny:

The haw thorn, which is also known as Mlay, Whitethorn and Nhespeine, is deeply cnshrined in the traditions of England where it has been a characteristic tree from the earliest days. The Greeks regarded it as the emblem of hope, and it was carried in their wedding processions, and used to deck the altar of Hymen. Its symbolism underwent a change in mediaeval times, however, owing to the belief that Christ was crowned with the branches of this tree, a belief that is quaintly told by Sir John Mandeville:

"Then was our Lord yled into a gardyn, and there the Jews scorned hym, and maden hym a crown of the branches of the Albiespyne, that is Whitethorn, that grew in the same gardyn, and setten yt upon hys heved. And therefore hath the Whitethorn many virtues. For he that beareth a branch on hym thereof, no thundre, ne no maner of tempest. may dere hym, ne in the howse that yt is ynne may non evil ghost enter."

The Holy Crown was reverently preserved at Constantinople for a time, but it was pledged to the Venetians as a bond for a large sum of money: It was acquired by St. Louis of France in the thirteenth century, who built the beautiful Sainte Chapelle for it at Paris. There is a legend that when the Emperor Charlemagne knelt before the relic in the eighth century, it blossomed afresh and the scent of hawthorn filled the air.

The celebrated Glastonbury Thorn of England is supposed to have sprung over night from the staff of St. Joseph of Arimathaea. It blossoms early in the year, sometimes as early as Christmas day; supposedly in honor of the Divine birth. 


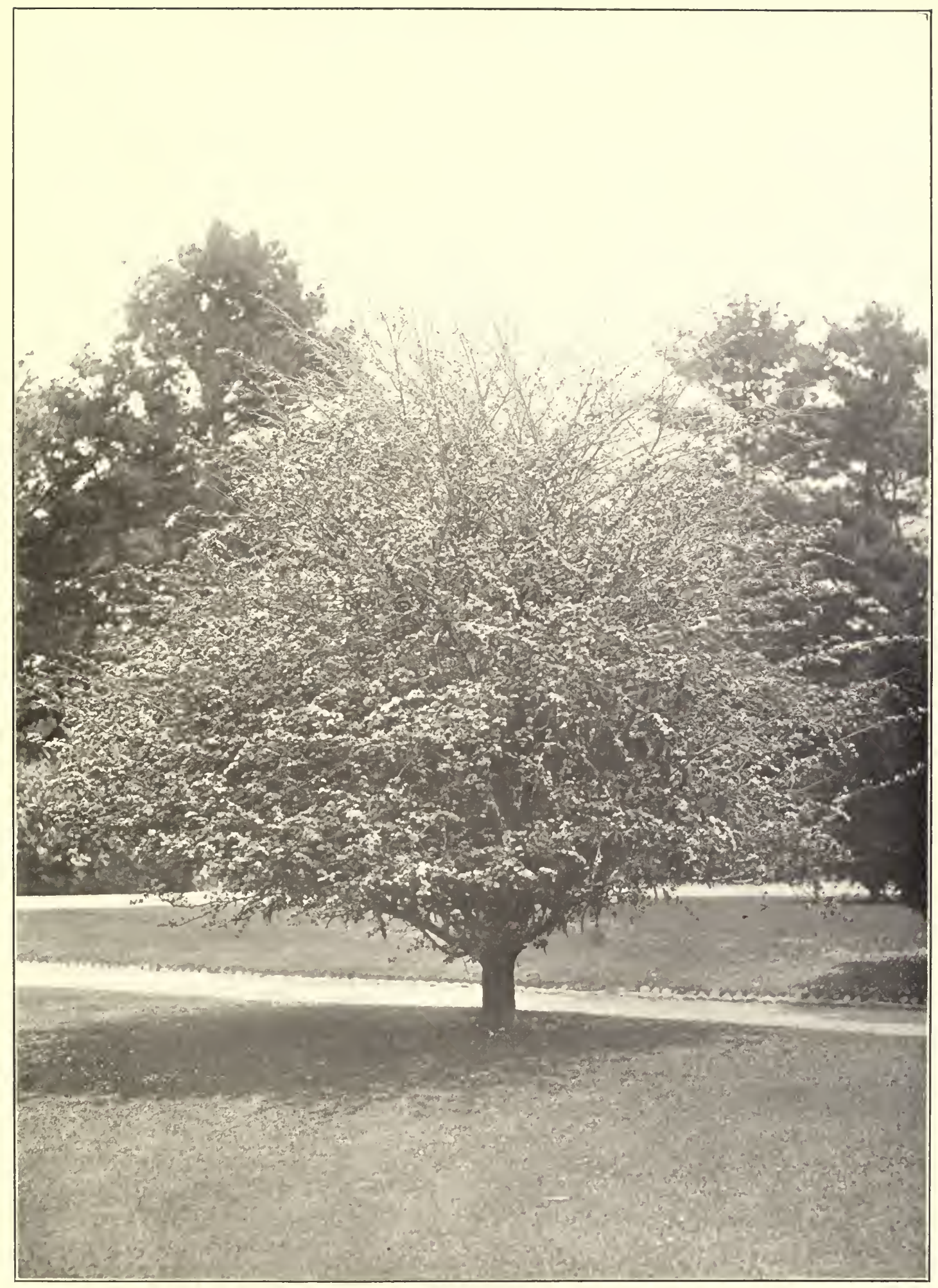

Plate 59. ENGLISH HAWTHORN. Del Monte.

"In hawthorn time the heart is light.

The world is sweet in sound and sight,

Glad thoughts and birds take flower and flight." -Swinburne. 


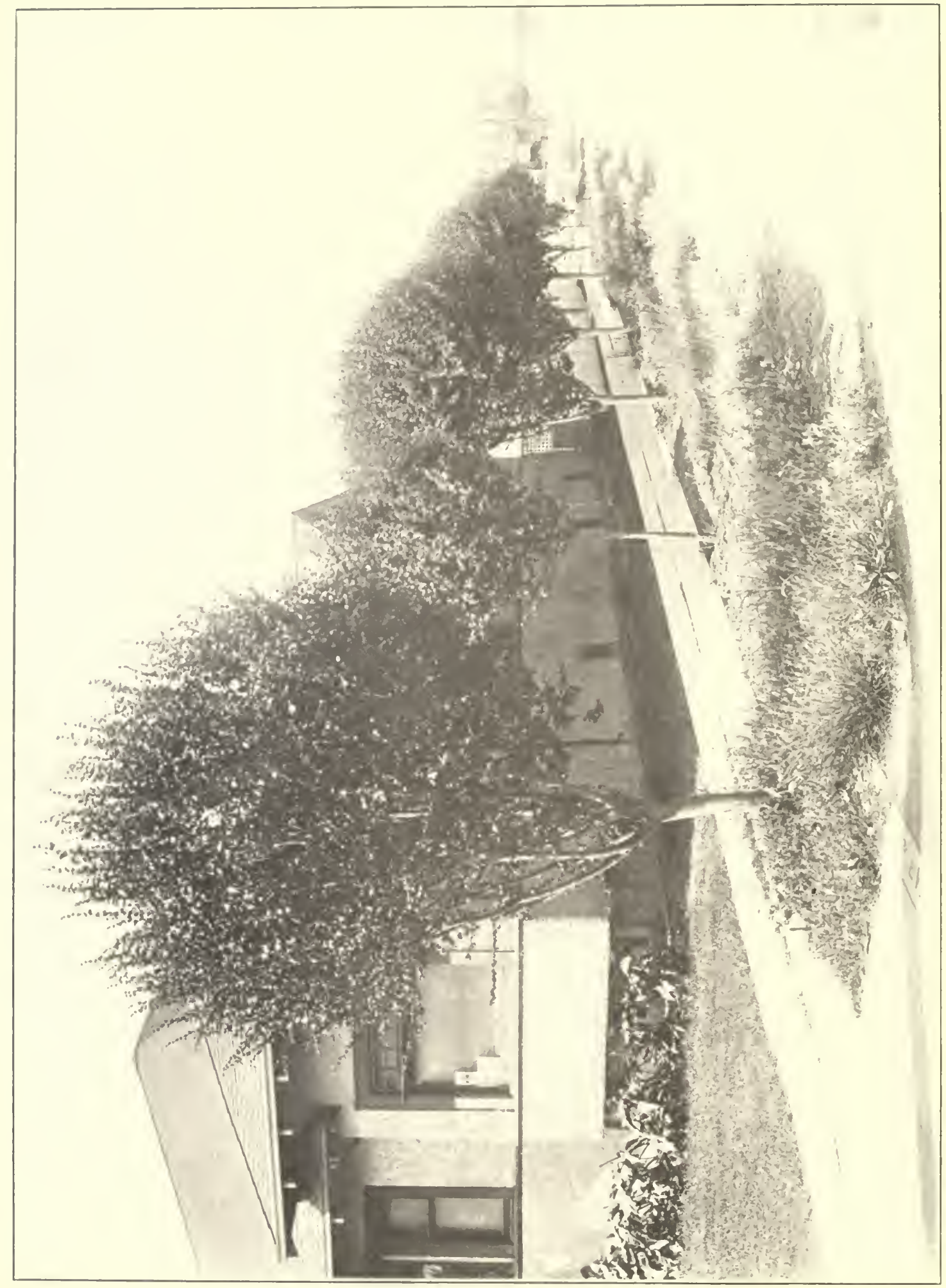


Henry VII adopted hawthorn for his badge because at the battle of Bosworth Field the crown of England was stolen from Richard III and hidden in a hawthorn. It was found, however, and the placing of it on the head of Henry immediately after its recovery gave rise to the old proverb, "Cleave to the crown though it hang on a bush."

No hardy flowering tree gives a finer color effect than the hawthorn, and it is widely used for ornamental purposes. It also makes an attractive street tree when small trees are desired. Its chief objection is its susceptibility to various insects, particularly the San Jose scale. The form is rather irregular, but can be easily trained. Hawthorns are easily transplanted, and flourish in good stiff loam or clayey soil.

\section{ENGLISH HAWTHORN}

The English hawthorn (Crataegus oxyacantha) is a celebrated hedge forming bush which reaches a height of thirty feet as a tree. The old trees have gnarled trunks, and thick bark scored by furrows. The branches carry short, sharp spines and in their winter condition are dense and matted looking.

The charm of the tree is most apparent in the spring when its branches are decked with tiny nosegays of rose-like flowers which crown the tree with "Mays fair diadem." After the petals fall the once snowy hawthorn assumes a crimson hue due to the myriads of red berries into which the flowers have been transformed.

The charm of the hawthorn at all seasons of the year has endeared it to the English people. Its place in their lives was observed by Goldsmith who says:

\footnotetext{
"The hawthorn bush, with seats beneath its shade,

For talking age or whispering lovers made."
}

\section{HICKORIES}

The hickories formerly formed extensive forests in Greenland and Europe, but no hickories are now found growing naturally outside of North America. Eleven species are found east of the Rocky Mountains and one in Mexico. The hickories were called walnuts by the early explorers since they resembled the Circassian walnut with which they were familiar.

The name is taken after the Indian word "Pawcohiccora," which was a dressing eaten with hominy, made from the milk of pounded hickory nuts. 
Captain John Smith mentions it in his account of his adventures among the Indians.

The hickories were much prized by the Indians, who made most of their bows and arrow's from their wood. They used hickory withes to bind their wigwam poles together, and the nuts furnished a valuable part of their winter's food. Fron the sap was made an ointment which ther used to supple their joints, and hickory ashes were used by them to preserve their meat.

The wood is very hard and tough, which may be the reason the term "Old Hickory" was given General Andrew Jackson by the soldiers, although this nickname may have been bestowed cluring the war with the Creek Indians in 1813 when he fed his men on hickory nuts when rations were short.

The hickories have been called the "artist trees" because of their picturesque appearance due to their shaggy bark, gnarled branches and stout twigs. In the springtime they are beautiful with dainty leaves and tasseled flowers, and in the summer their handsome light-green leaves cast a heary shade. When autumn comes the leaves turn to a clear yellow. There is an old belief that if they are brilliant yellow, the next harvest will be a rich one.

The hickories reach their best development in the southern Appalachians. The most important one is the shag bark (Hicoria otata), which attains a height of 120 feet and a diameter of three to four feet. The long, ragged strips of bark that clothe the trunk give it its name.

All the hickories make their best growth in good, rich, bottom soil and in sheltered situations. They are slow-growing, but form handsome broad heads and live for many years. Very few hickories have been planted in California, but there is no reason why they should not do well when planted under proper conditions.

\section{PECAN}

The pecan (Hicoria pecan) is the most imposing of the hickories in its native habitat in the Southern States, where it is found on low, rich ground in the vicinity of streams. Near Baton Rouge, Louisiana, is a tree which measures over eighteen feet in circumference at breast height and which is over 150 feet in height.

There is a weird story relating to a leafless pecan tree which formerly stood near New Orleans. In the battle of New Orleans, January 8, 1815, the British lost a number of officers among them being General Packenham. 


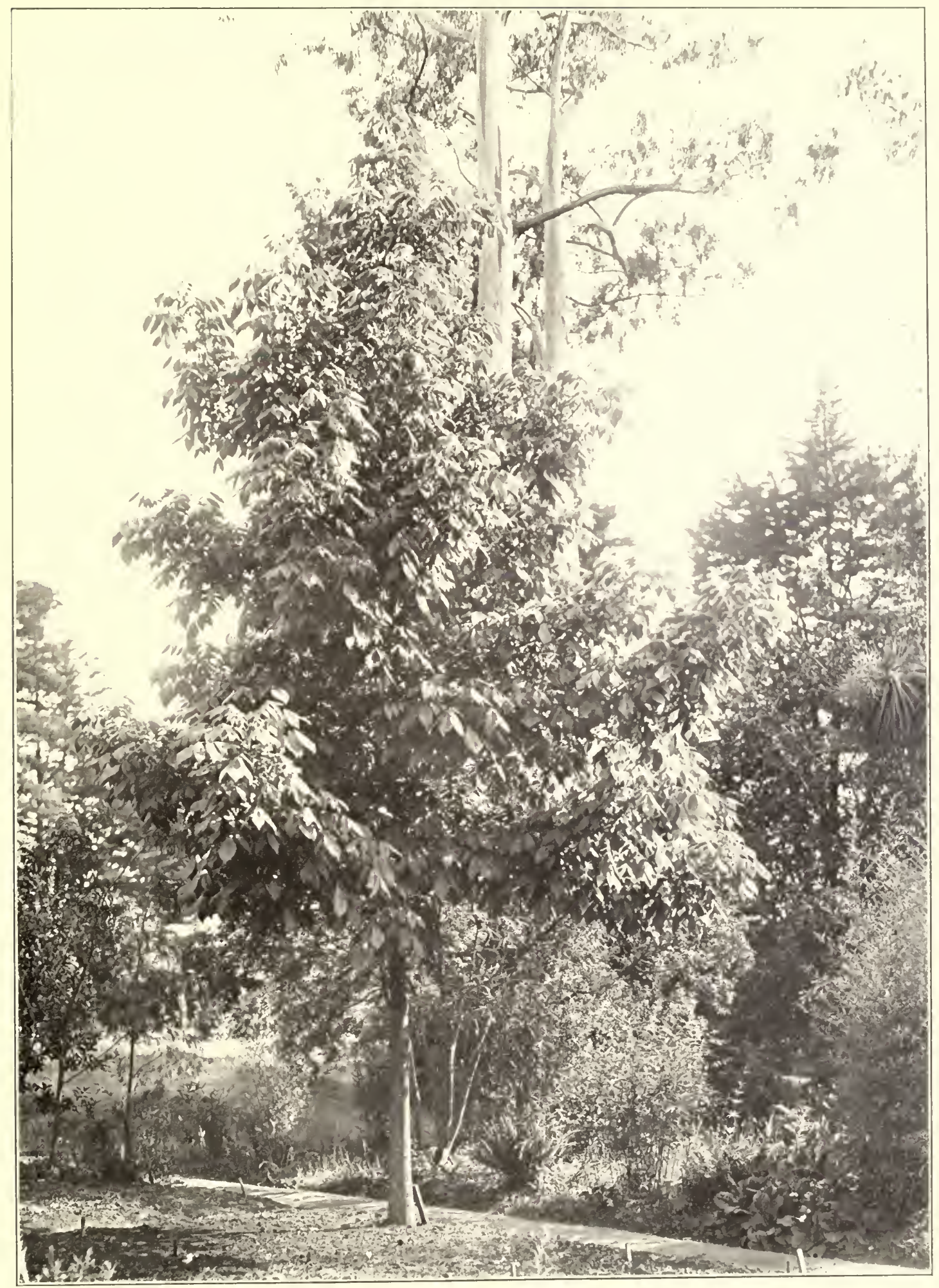

Plate 61. SHAG-BARK HICKORY. Berkeley. 


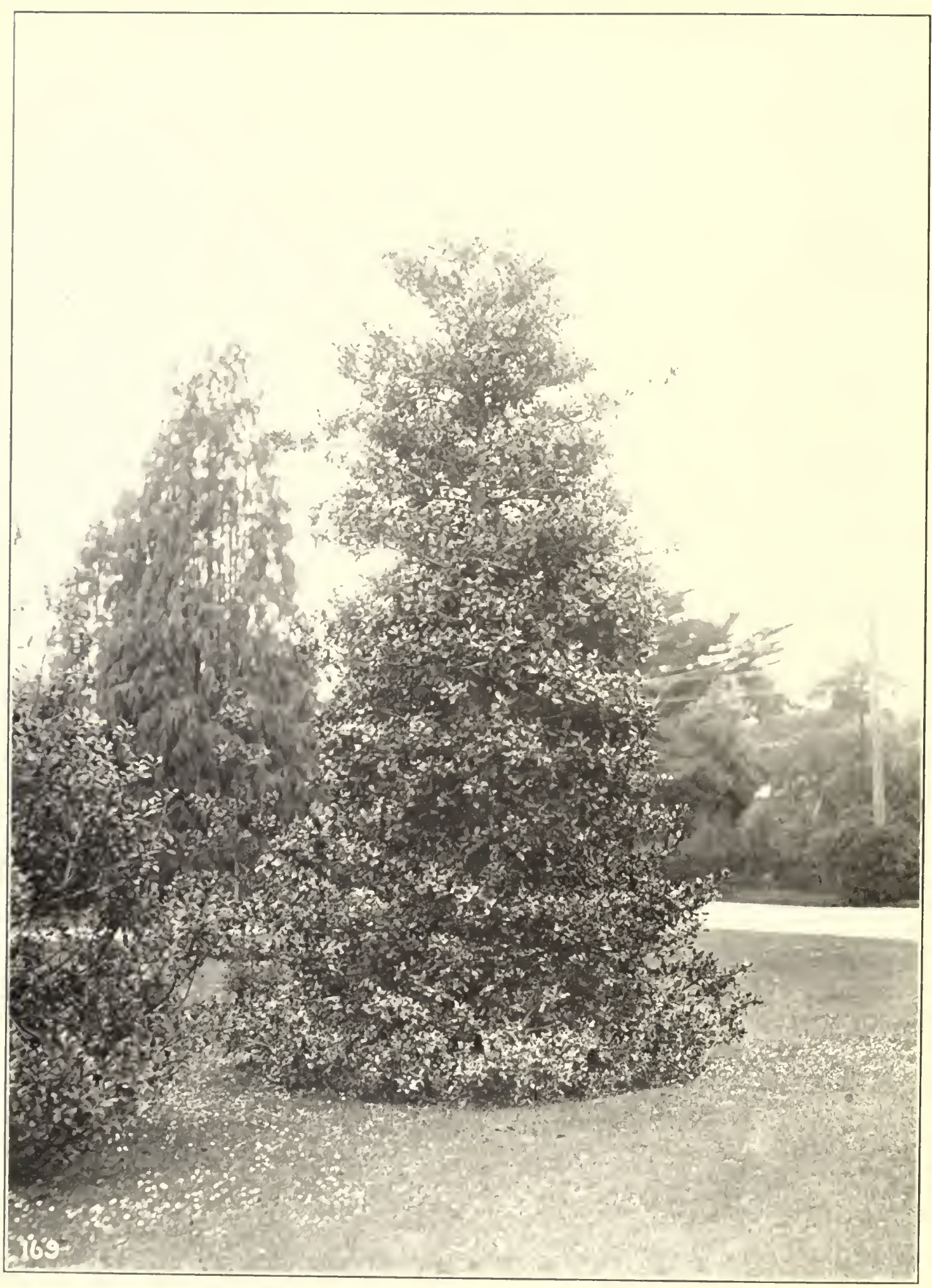

Plate 62. HOLLY. Del Monte.

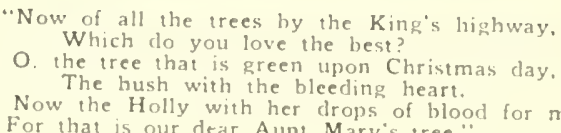


It was decided to ship their bodies to England, preserved in casks of rum. Part of the preparation consisted in removing the internal organs, which were buried uncler the pecan tree already mentioned. The story goes that this sympathetic tree promptly dropped its leaves, and superstitious negroes for decades pointed to blood stains on its trunk.

The pecan has much economic importance because of its nuts, which are long, smooth, reddish and slender, and so thin-shelled that they may sometimes be crushed with the fingers. Aside from its value as a nut-bearer, however, the pecan is a beautiful ornamental and shade tree which well deserves a thorough trial in California.

A tree of this species near the Bidwell residence in Chico is 120 feet high and one of the stateliest of the many beautiful trees on the grounds.

On the Patterson ranch near Newark, Alameda County, are five specimen trees of the King-nut (Hicoria laciniosa) and the Shagbark hickory (Hicoria ovata), which were grown from nuts brought across the plains by Mr. Patterson in the late ' 50 's.

\section{HOLLIES}

The hollies belong to the genus Ilex, which is the classical name of the evergreen oak of Southern Europe. They are small trees and shrubs which have much ornamental value because of their evergreen spiny foliage, their delicate, white flowers and bright red berries.

From the earliest days the holly has had a religious significance. There is a tradition that the holly sprang up beneath the footsteps of Christ when he first walked on earth, which led to the belief that it was reverenced by animals, who were never known to injure it. To Christians the evergreen leaves spoke of immortality and the blood-red berries foretold the Passion. The Romans used holly branches in their winter festivals of Saturnalia, and when Christianity supplanted heathen worship the custom was carried on until now the holly is associated with Christmas festivals.

Many superstitions are connected with the use of holly at Christmas chiefly on account of its leaves. The upper leaves on the tree tend to lose their prickles, which are abundant on the lower leaves as a protection against browsing animals. In the north of England the prickly leaves are known as "He-Holly," and the smooth leaves as "She-Holly." It is popularly believed 
that if the "He-Holly" is hrought first inte the house on Christmas eve the hushand will be master throughout the year, but if the "She-Holly" comes first then the wife will run the houschold.

(On Christmas Eve tiny pieces of lighted candle are placed on holly leaves. which are set to float in a tub of water. Each leaf represents some person, who gives it a wish. If the leaf remains aftoat it is helieved the wish will be gratified. If it sinks, the wish will not he fulfalled.

\section{ENGLISH HOLLY}

The English holly (Ilex aquifolium) is a small tree rarely exceeding fort! fect in height. It is frequently planted to form a dense prickly hedge, and it is said that Peter the (ireat worked off some of his spare energy running a wheelbarrow through such a hedge.

As a tree the holly is picturesque with its dark-green leaves, which form a contrast with the bright greens of surrounding trees in summer and the leafless hranches in winter. It had a joyful effect on Shakespeare, who wrote:

"Heigh-Ho! the green Holly!

This life is most jolly:"

1 folly has a slow growth and thrives best in deep, rich soils where there is plenty of shade and moisture. Its great shade-endurance fits it for under planting or for grouping with other evergreen foliage.

$A$ row of holly trees planted for ornament around two sides of a large lot in Portland, Oregon, some years ago, has yielded Christmas decorations to the value of over $\$ 500$ per year for the last two years without injuring the trees.

\section{HORSE CHESTNUT}

The horse chestnut (Aesculus hippocastanum) is thought to have come originally from the mountains of Greece. It is largely planted in all countries with temperate climates and makes a sturdy tree of strong growth. It has a roundish outline and a somewhat coarse branch habit with the tips of the branches peculiarly curved upward. The tree reaches a height of about eighty feet and has a smooth cylindrical bole which rarely exceeds two feet in diameter. 


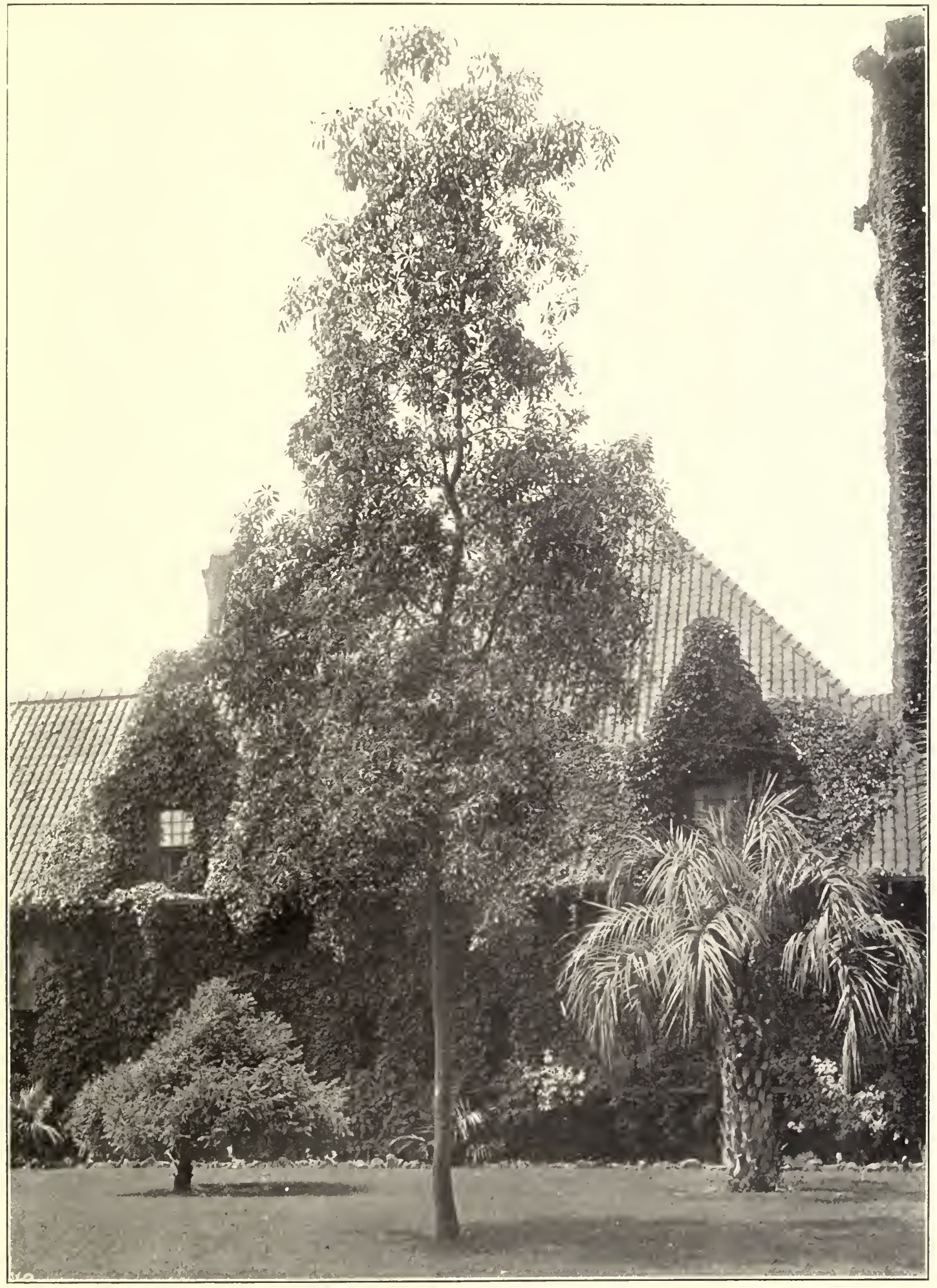

Plate 63. HYMENOSPORUM. Las Angeles.

An Australian tree the branches of which are laden in spring with jasmine-scented yellow flowers. 


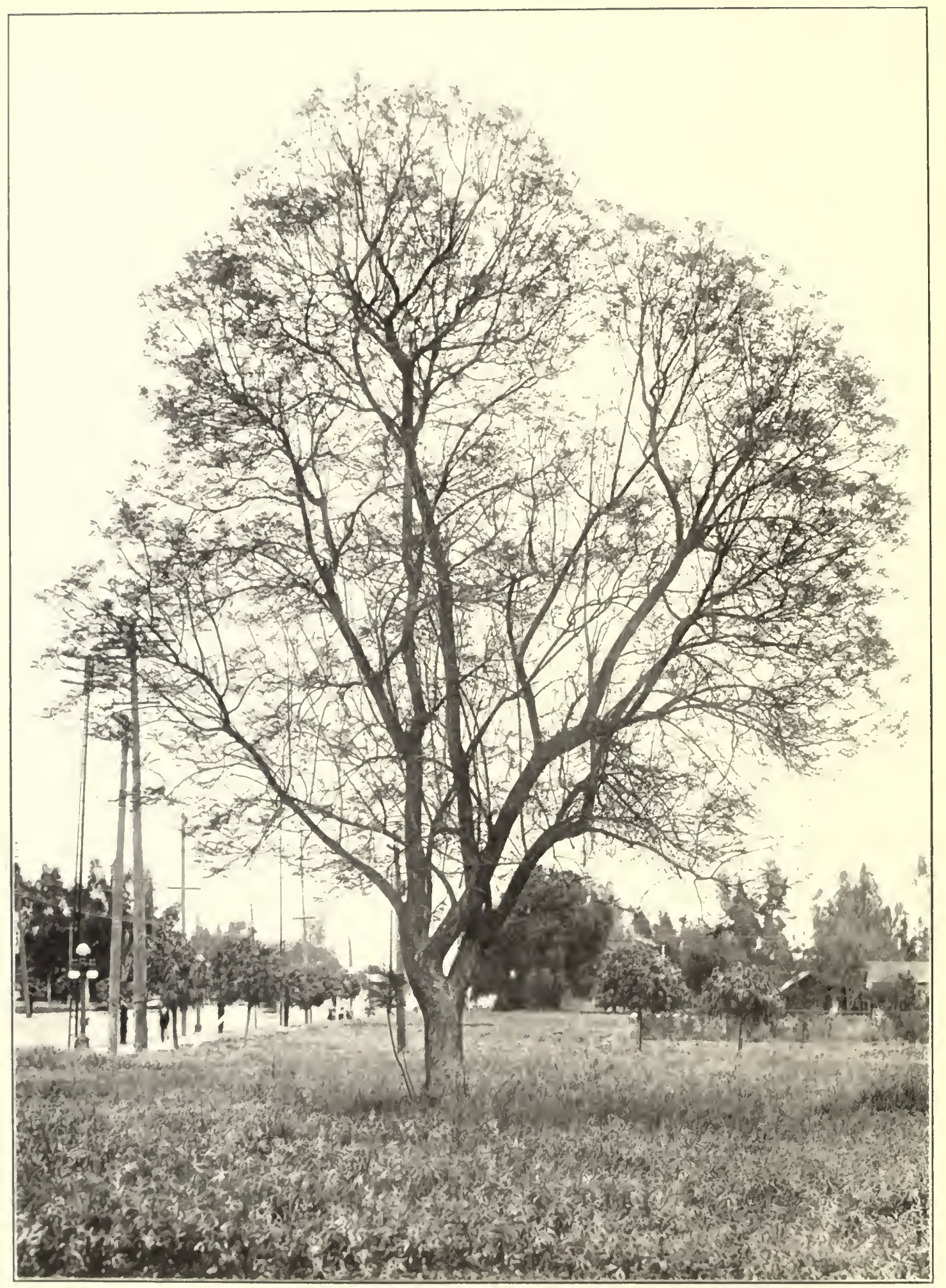

Plate 64. JACARANDA. San Diego.

A native of Brazil which does well in subtropical regions. It has finely cut fern-like foliage and large blue bignonia-like llowers. 
In the spring the large chocolate-colored buds begin to swell and the varnished coats that protected them during the winter soften. First one pair and then another pair of delicate green leaflets make their appearance.

"When drooping chestnut buds began

To spread into the perfect fan."

Finally there is a dense foliage of leaves, each composed of seven leaflets arranged in a palmate manner, each broad at the outer end and tapering towards the point of their insertion on their common leaf-stalk.

Just as the leaves are spreading themselves out of the terminal buds, the large flower spikes rise between the last pair. When in full flower the tree has been called the "Giant's Nosegay;" while the children think of it as a huge Christmas tree covered with white tapers.

In the fall the leaves become bronzed and fall, leaving horse-shoe like scars, nail marks and all, on the branches. The large polished brown seeds which are wrapped in leathery overcoats on the tree are not good to eat, but children value them for their games. It is said that the Turks pounded them up and fed them to their horses to improve their wind.

The horse chestnut has been successfully planted on California city streets, particularly in Hayward. It has been a favorite tree for avenues and parks in Europe for centuries, one of the finest avenues in the world being in Bushey Park, near London. Five rows of the trees stand on either side of the avenue and when they are in bloom they afford a superb sight, "a pyramid of green supporting a thousand pyramids of white." There are over 17,000 horse chestnut trees on the streets of Paris. Their main objection is the continual dropping that takes place throughout the year, either of leaves, flowers, or nuts.

\section{HYMENOSPORUM}

The Hymenosporum (Hymenosporum flaum) is an Australian evergreen tree or shrub which is closely related to the Pittosporums, but which excels them in many particulars. It has a pyramidal growth with drooping branches which are laden in spring with a profusion of jasmine shaped and jasmine scented yellow flowers. It is a free bloomer over a long period. The leaves are smooth, glossy and light-green in color. 
This tree has a rapid growth and its shape well adapts it for strect and garden planting. It is not particular ahout quality of soil. but needs a moderate amount of moisture. At present it is quite rare, but its many good qualitics make it deserve more extensive planting. L'nder favorable conditions it attains a height of about fifty feet. It cannot stand much frost. however, which does not recommend it for the interior valleys.

\section{JACARANDA}

The jacaranda (Jacarandu otalifolia) is a native of Brazil which does well in subtropical regions. It reaches a height of ahout fifty feet and commands attention in the carly summer by its profusion of large blue panicles of bignonia-like flowers and finely cut fern-like foliage. The shape of the tree is apt to be straggling unless it is carefully pruned.

This tree is used on the streets of Santa Barbara and Pasadena with good effect. It is too tender for regions of severe frost, and thrives best in warmer situations sheltered from strong winds.

\section{JERUSALEM THORN}

The Jerusalem thom (Parkinsonia aculeata) takes its generic name after John Parkinson, an English botanical author and herbalist to James I. It grows naturally in Texas, Arizona and Mexico and is cultivated in many warm countries as an ornamental small tree and to form hedges.

It is a thorny evergreen tree with feathery drooping branches and fragrant yellow flowers borne on racemes. It reaches a height of about fifteen feet under cultivation, the pendulous branches forming a wide, graceful head. The pods, commonly known as horse beans, which are constricted between the seeds, hang in graceful racemes from the tree.

This tree, which belongs to the same tribe as the honey locust, will thrive in the driest soil and can endure considerable cold.

\section{EUROPEAN LAUREL}

The European laurel, commonly known as the sweet bay, was regarded by ancient peoples as an enblem of truth and it was forbidden to put it to any profane use. It was a favorite tree of poets and scholars, and graduates 
of universities were known as "laureates" because of the wreaths of laurel with which they were crowned.

A Greek myth relates that Apollo, after slaying the Python, fled for purification to the laurel groves of the vale of Tempe. While here he fell in love with the nymph Daphne who fled from him. She prayed for deliverance to her mother Earth, who heard her and opened the ground so that she might hide. On this spot there sprang up a laurel tree which Apollo declared to be sacred. Afterwards when he instituted the Pythian games at Delphi to commemorate his victory over Python, the prizes awarded the victors were made from the leaves and berries of the laurel.

An English writer writes about the laurel as follows:

"The sweet bay bush in the farmer's or cottage garden comes with its story from the streams of Greece, where it seeks moisture in a thirsty land along with the wild olive and the arbutus. And this sweet bay is the laurel of the poets, of the first and greatest of all poet and artist nations of the earth - the laurel sacred to Apollo, and used in many ways in his worship, as we may see on coins, and in many other things that remain to us of the great peoples of the past."

The Romans believed that the laurel afforded protection against lightning, and the Emperor Tiberius, when it thundered, wore a laurel wreath made from the tree at the imperial villa on the Flaminian Way.

There are only two species of the genus Laurus, one native to the Mediterranean region and one to the Canary Islands. The Siveet Bay (Laurus nobilis) reaches a height of from forty to sixty feet. It branches close to the ground and bears dark green, oblong leaves which give a heavy shade.

The laurel is most commonly grown as a tub plant, with which to decorate porches and formal gardens. The head can be trimmed to any shape desired, which makes the tree in demand by architects for the proper setting of their building designs. The trees will do well in the open since they stand considerable frost and heat.

\section{EUROPEAN LINDEN}

The European linden (Tilia europea), which is a celebrated street tree of Europe, is similar to the American basswood, but has smaller, deeper green leaves and red or yellow branches. This tree is commonly called "Lime Tree," 
which name was derived from the old English word "lyne" meaning pliant, in reference to the tough fibres of the inner bark which furnished the bast of gardeners.

The linden is a stately tree with heart-shaped leares which led the poet Heine to say:

"Therefore are the lindens ever

Chosen seats of each fond lover."

A striking feature of the tree is the downward droop of the buds which affords better protection for the young and tender leares. The trees are straight-stemmed with smooth bark and when fully dereloped are from eighty to ninety feet in height. Germany is noted for its lindens, one of the most famous being a tree nine feet in cliameter at Neustadt in Winternberg and which gave it the name of "Xeustadt an der grossen Linden."

The flowers are vellowish-green and very fragrant, which makes them attractive to bees. The flowers are followed by small berries, which are often conspicuous because of the peculiar blade-like structure from which they grow, which aids in their listribution by the wind.

Mythology has a story to account for the existence of the linden. It is related that an aged shepherd and his wife once entertained Jupiter and Mercury unawares. When their guests declared themselves, the aged couple were askel to claim a reward and they chose that they should each become a verdant linden. Hence, the linden has become the symbol of wedded love.

Lindens were extensively planted in 1660 in England at the instigation of John Evelyn, who said "Is there a more ravishing or delightful object than to behold some entire streets and whole towns planted with these trees in even lines before their doors, so that they seem like cities in a wood?"

Luther Burbank regards the linden as one of the best trees to plant in the coast region. In the interior valleys, it does not do well because of the high temperatures which sometimes prevail.

\section{MADRONA}

Madrona (Arbutus menziesii) is a handsome native tree which belongs to an ancient genus frequently mentioned by the classical writers of Greece and Italy. Theophrastus describes the strawberry tree (Arbutus unedo) as a tree possessing an edible fruit like unto a strawberry, a smooth bark, and a 


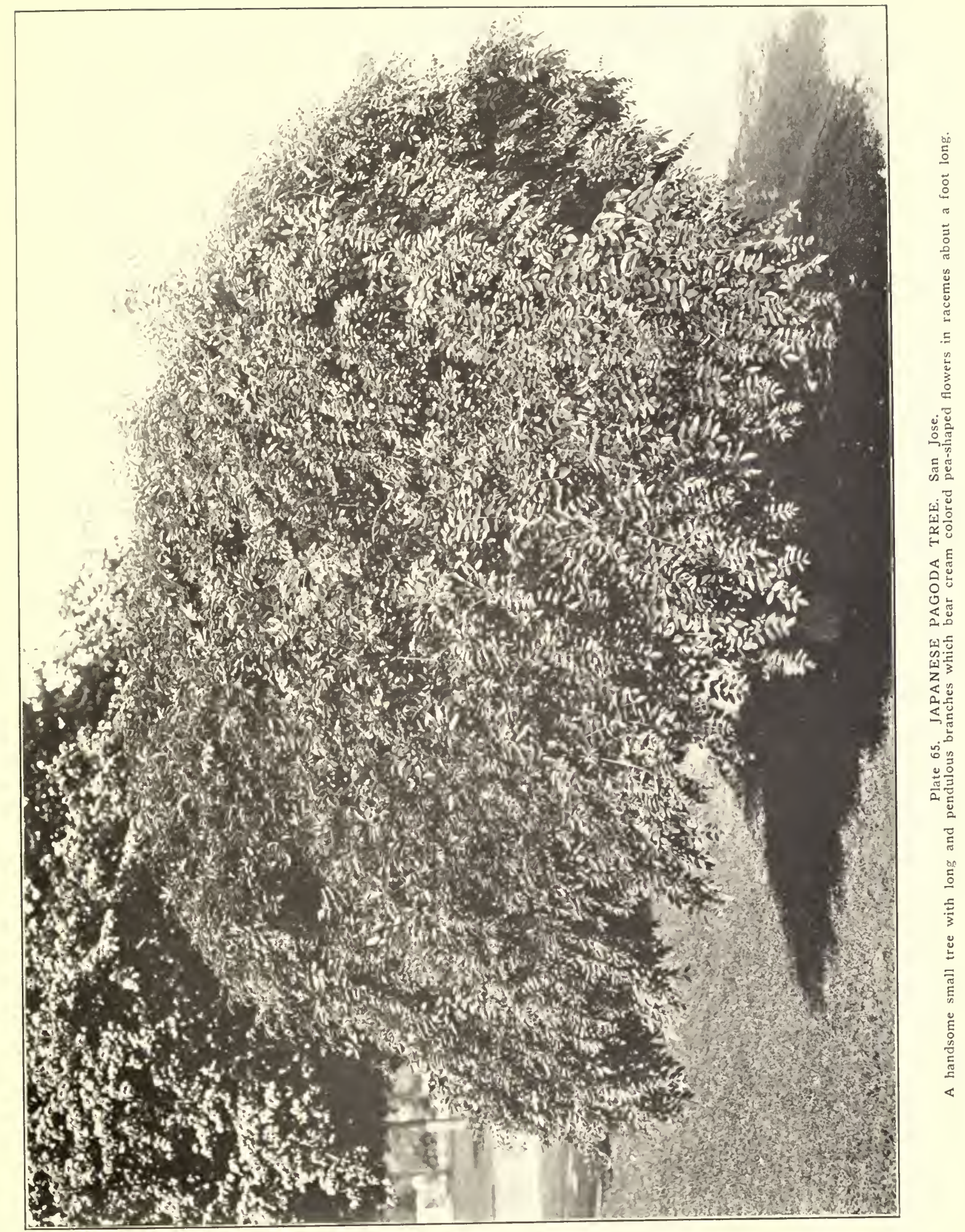




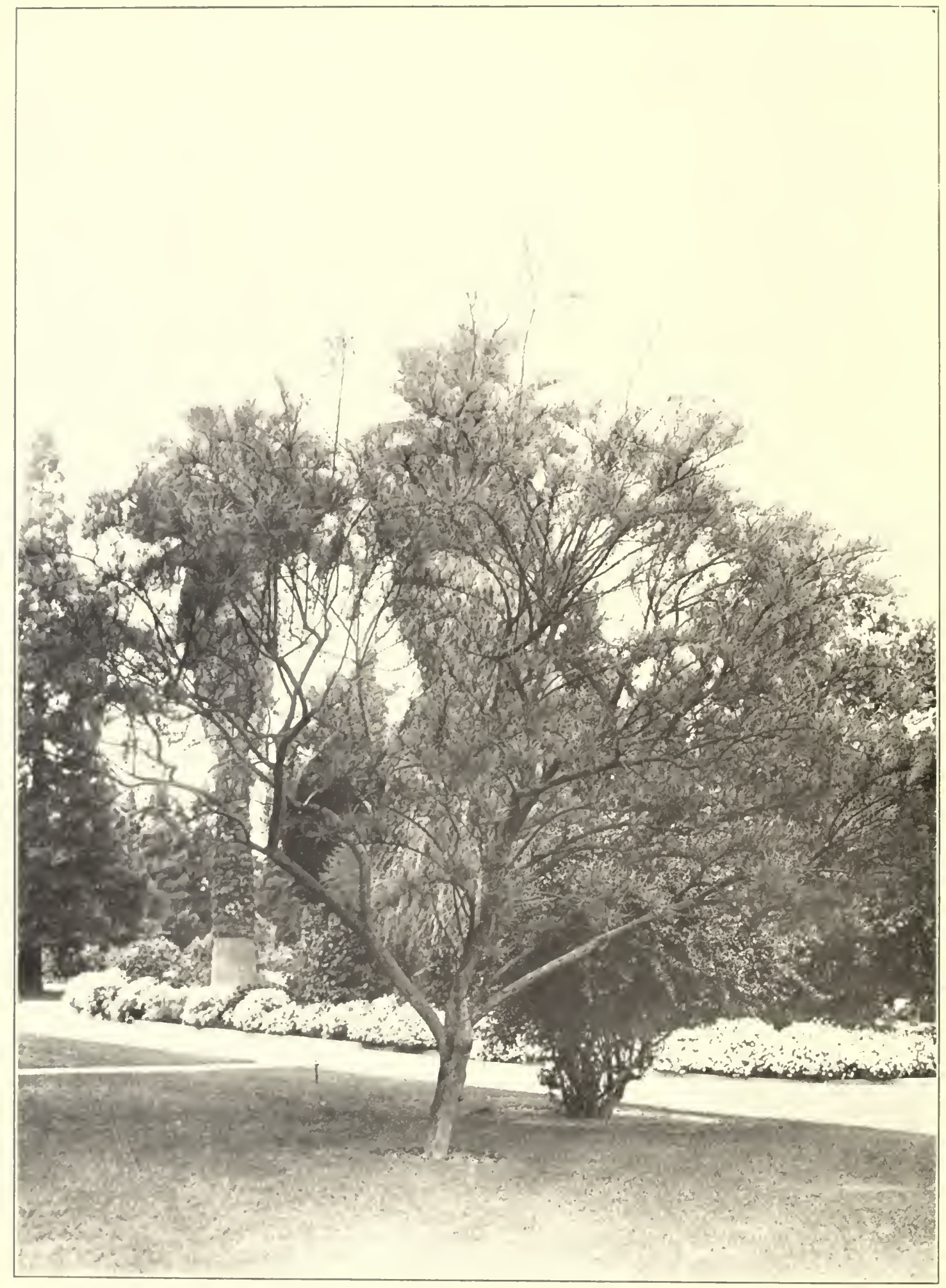

Plate 66. JERUSALEM THORN. Pasalena.

A thoslly cver, reen tree with feathery dronpin: brancies and fratrant veltow flowers. 
leaf intermediate between the oak and the bay laurel. Each blossom, he says, equals in size and form a long myrtle blossom, so that it is formed like an eggshell cut in half. Ovid celebrates its loads of "blushing fruit," and Horace, in his first Ode, expresses his delight in lying with limbs stretched beneath a green arbutus.

The madrona of California was given its name by the Spanish Californians after the arbute tree of Spain which they knew as madrona. It was first collected in I791 by Menzies, and was one of the first Pacific Coast trees to be described by botanists.

Mladrona is widely distributed in the coast mountains, and occurs on the west slopes of the Sierras, and in the San Bernardino Mountains. On the north coast, where it reaches a height of 125 feet and a diameter of four feet, it is found on the slopes with redwood, Douglas fir, tan oak and black oak. The beauty of its foliage, flowers, and trunk are sources of never-failing interest to the traveler.

The madrona is very little known to cultivation but should make a strong appeal to Californians. Professor W. L. Jepson of the University of California speaks of it as follows:

"That madrona has thus far no place in California gardens is partly to be explained by the unhappy preference for exotics and because the tree as it grows in its native woods is little known to the people. For beyond any peradventure of doubt it is the most handsome tree in California and enlivens the forest and groves with its unrivaled woodland colors. Of slight economic importance as a timber species, it is in every other way a notable tree. Its crown of flowers and masses of crimson berries, its burnished foliage and terra-cotta bark, its manner of branching and habits of growth are alike full of interest and of charm."

\section{MAGNOLIAS}

The magnolias, which belong to a family of very ancient lineage, are widely distributed, species being found in the Himalayas, China, Central America and southeastern United States. The genus is named in honor of Pierre Magnol, professor of botany at Montpellier in France.

There are seven species of magnolia in southeastern United States, several of them being timber trees of consequence. They flourish in rich, moist soil 
along rivers and swamps, and command attention by their large. showy flowers and glossy green leaves clustered on the ends of the branches. Some of the species keep their leaves throughout the year. while others are deciduous The hranch habit is generally open and straggling, although some species have shapely outlines. Magnolias stand some frost, hut long periods of severe cold are detrimental

There formerly stood near Charleston, South Carolina, a stately magnolia which was known as the Magnolia Council Tree. It was under this tree in 17 So that council was taken with the people of Charleston by General Lincoln. They were told that the enemy had been strongly reenforced and that further defence of the city seemed hopeless. He was prevailed upon to stay, but was forcel to surrender three weeks later. This tree was felled in $18+9$ by a farmer for firewood.

\section{LAUREL-LEAVED MAGNOLIA}

The laurel-leaved magnolia (Magnolia grandiflora). also called Bull Bay, is a well known tree of splendid appearance which is widely known as an ornamental tree. It is the most magnificent of the broad-leaved evergreens of the Southern States, where it reaches a height of eighty feet. The growth is slow but erect, and at maturity the crown reaches such a size as to render the tree suitable only for wide streets, even though for years, owing to its slow growth, it may appear to be inadequate. The chief drawback to its use for street and avenue planting is the continuous litter which it makes.

The laurel-leaved magnolia has large, leathery; glossy, green leaves which form a heavy mantle throughout the year. The great attraction of the tree is its lemon-scented waxen white flowers which are six to ten inches broad. In the spring this magnolia presents a striking picture with its many hundreds of these showy flowers. Just before the bud matures to a perfect flower it has a heautiful oval figure resembling a half opened rosebud. In a few hours the large petals unfold into a flower in the center of which is a small cone of delicate green shade. No bloom of any tree is so large and fragrant, yet so delicate and beautiful. After the flowers are gone a cone develops with seeds the size and shape of beans. A perfume is made from these seeds which possesses the same sweet, delicate scent as the flower. 


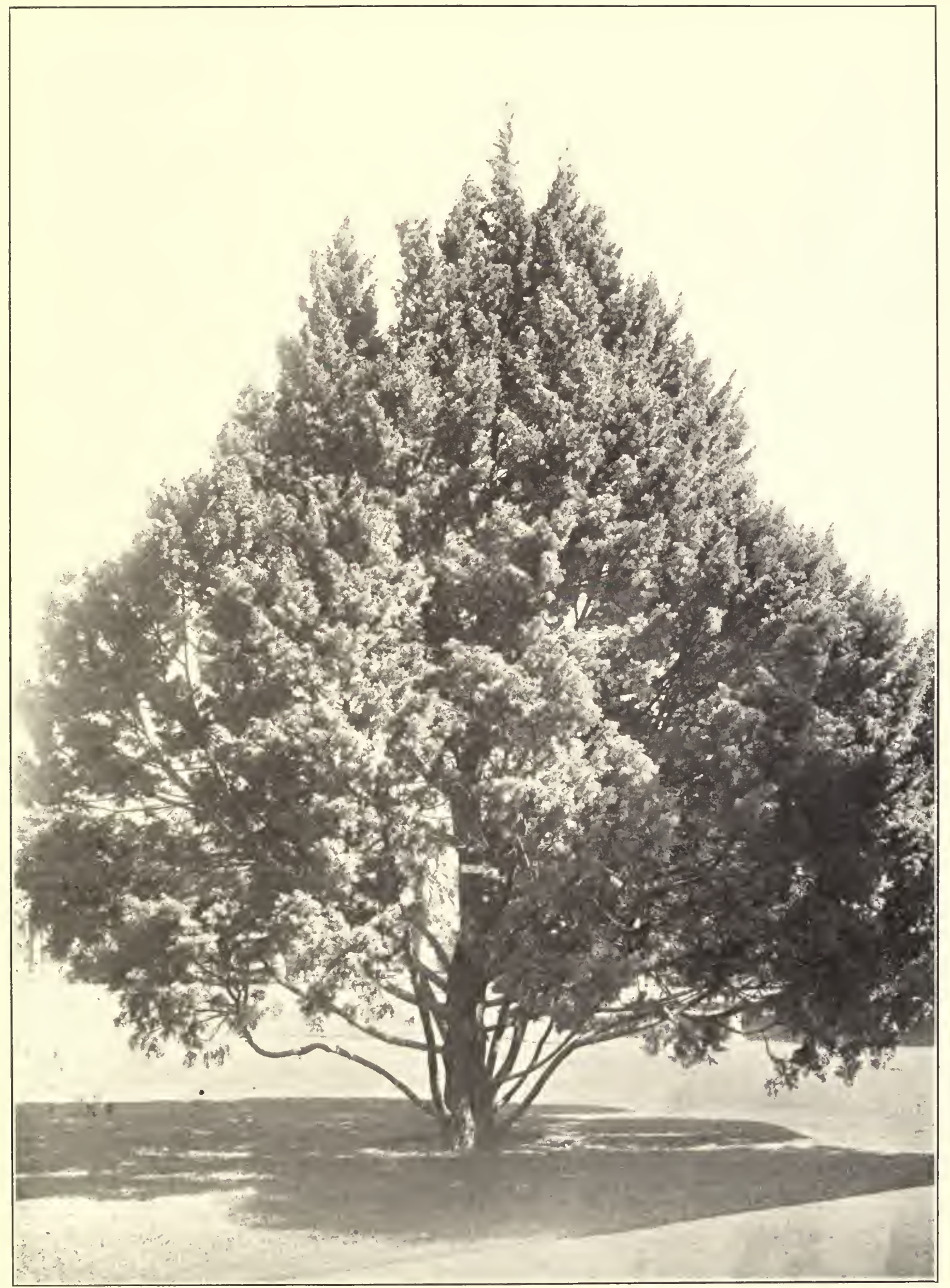

Plate 67. JUNIPER. Sacramento.

An evergreen tree with very glaucous foliage. Although it is a conifer, yet it does not bear cones, but berry-like fruits. 


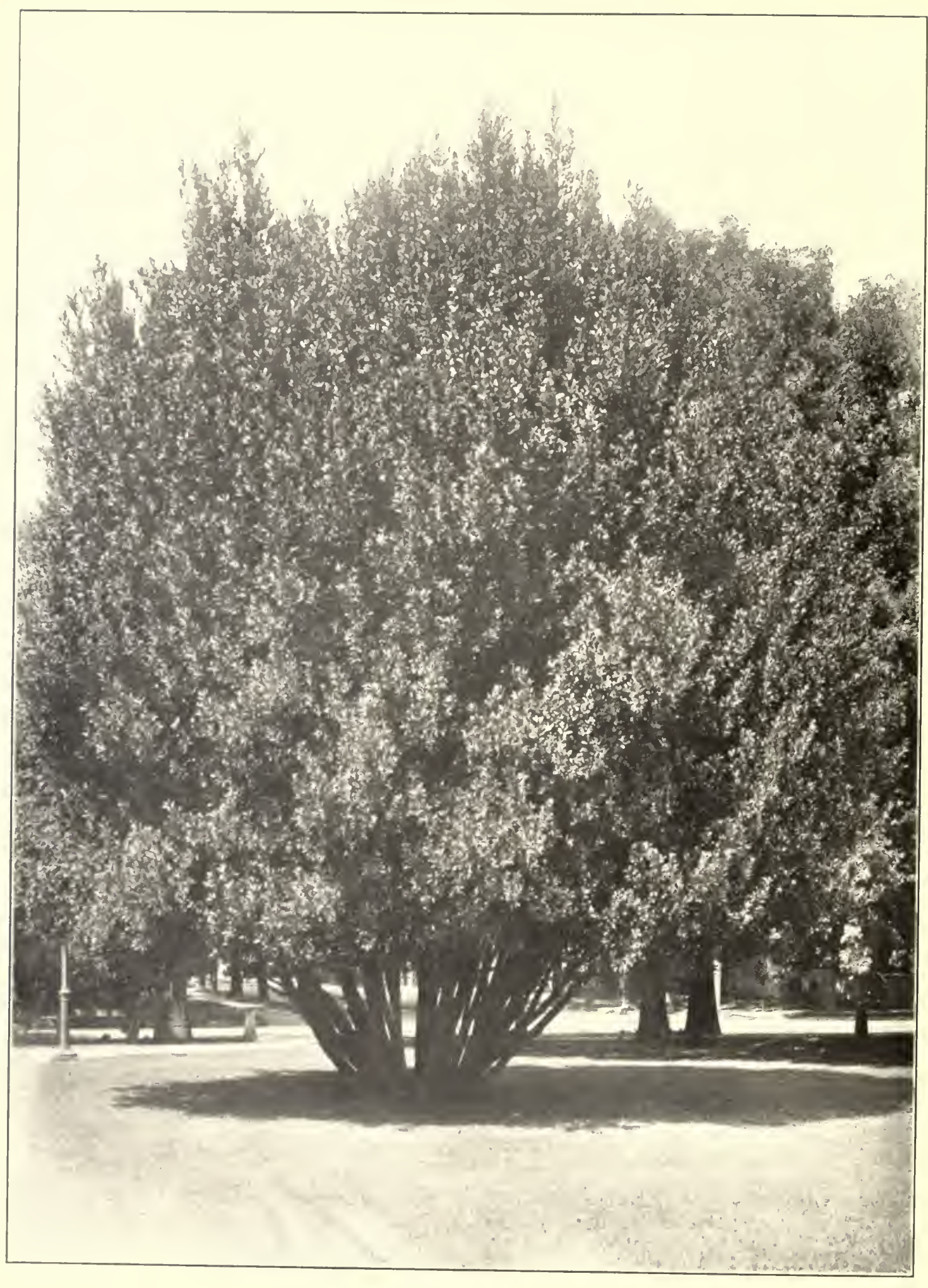

Plate 58. EUROPEAN LAUREL. Sacramento.

the poets and of putting laurel leaves bnder one to communacate the spirit of poetry. Hence the custom of crowning 


\section{CHINESE MAGNOLIAS}

The Chinese magnolias are deciduous and have entirely different habits than the evergreen magnolias. They are shrublike in character, and are prized for the profusion and beauty of their early flowers. The buds form in the fall and open in the early spring before the leaves appear. There are many species and varieties, varying chiefly in color and size of the flower.

Wherever magnolia is planted care should be taken to supply it with an abundance of water; otherwise, the foliage will lose its richness of color and the growth will be perceptibly retarded.

\section{MAPLES}

Acer, the scientific name of the maple family, means hard or sharp, and was given to the maple by the ancients because of its hard wood which they prized for making their weapons.

One of the maples is called Sycamore in England. This name arose from the practice of using the tree in mystery plays in the Middle Ages to represent the true sycamore which Zacchaeus climbed to see Christ at the time of his triumphal entry into Jerusalem.

Virgil celebrates the maple as the throne on which Evander seated Aeneas:

"On sods of turf he sat the soldiers round;

A maple throne, raised high above the ground

Received the Trojan chief; and, o'er the bed,

A lion's shaggy hide for ornament they spread."

The maples embrace sixty to seventy species of large, medium and small sized trees. They have a wide range and are adaptive to a variety of soils. The flowers are small but are attractive in early flowering species since they appear in great profusion in the form of drooping clusters. The foliage has a pleasing diversity of shape and color, generally turning into brilliant tints in the autumn. Tennyson describes the maple as burning itself away until all the woodside glows in the fitful sunshine like dead gold.

In some species the young fruits which have two seeds joined, Siamesetwin fashion, assume a deep red color which led Emerson to say:

"The scarlet maple keys betray

What potent blood hath modest May." 
Perhaps the red and scarlet coloring of the maples has something to do with the name "Grief Trees" given to certain trees in the West of Scotland, but more particularly because it was on these trees that the barons used to hang their enemies.

The maples are valuable trees for park and street planting. The majority have an upright habit, make rapid growth and are little subject to insect attacks. They do not flourish, however, under arid conditions.

\section{SUGAR MAPLE}

The sugar maple (Acer saccharum) which has a natural range from Newfoundland to Georgia, and westward to Manitoba and Texas, is a hardy, erect tree of symmetrical habit. In the forest it rises to sisty or seventy feet without a branch. In the open it develops stout, upright branches about ten feet from the ground which form a narrow head while the tree is young. Old trees have hroad, round-topped crowns which cast a dense shade.

Sugar maple requires a cool climate and abundant moisture for its best development. Unfortunately it is apt not to thrive in cities because of its exacting requirements, and the sensitiveness of its foliage to dust and smoke. It should do well in the northern part of California as a roadside tree for which it is desirable because of its fine foliage and long life. The winter condition of the sugar maple is especially striking when the erect, shapely outline of the tree is clearly brought out with the twigs and branches forming a fine network against the sky.

\section{BIG-LEAF MAPLE}

The big-leaf maple (Acer macrophyllum), often called Oregon maple, is a native tree which is widely distributed along the streams and creeks in the Coast ranges from southern California to southeastern Alaska. It is also found in the Sierra Nevadas along streams at elevations ranging from 2000 to 5000 feet.

The big-leaf maple was first collected by the Lewis and Clark expedition in 1805 at the great rapids of the Columbia River. Its wood was used by the Indians for boat paddles, and the twigs were valued as medicine to bring riches. The beauty of the tree was early appreciated, and it is probably more widely planted as a street and ornamental tree on the Pacific Coast than any other maple. 


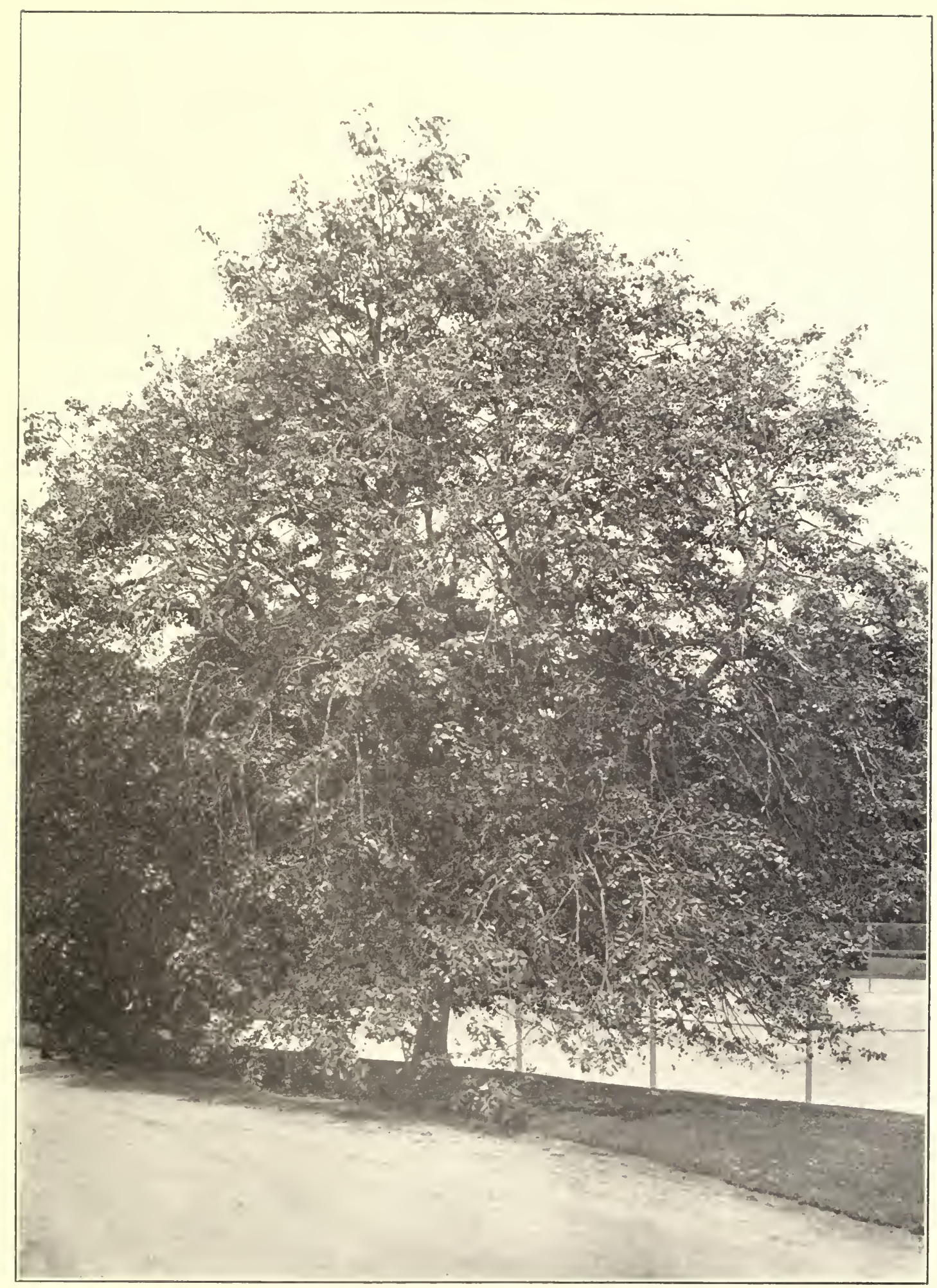

Plate 69. EUROPEAN LINDEN. Del Monte.

"Here a iinden tree stood, bright'ning

all adown its silver rind.

-Browning. 


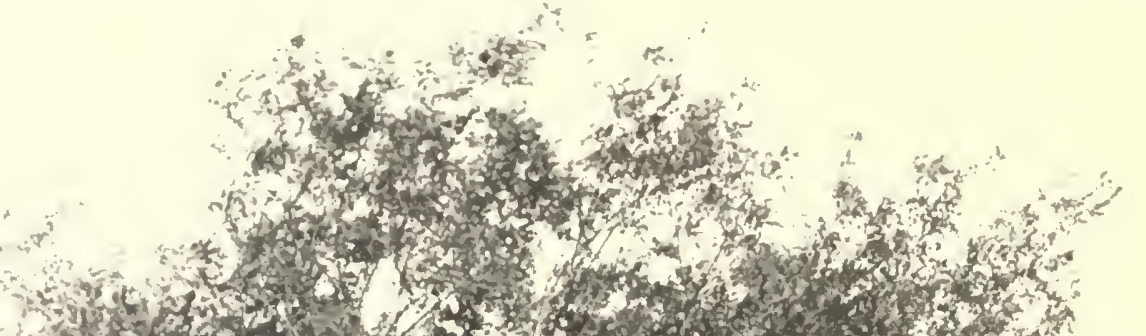
r.w.

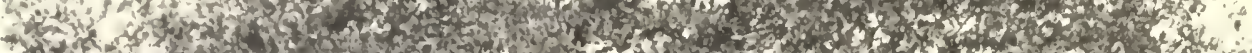

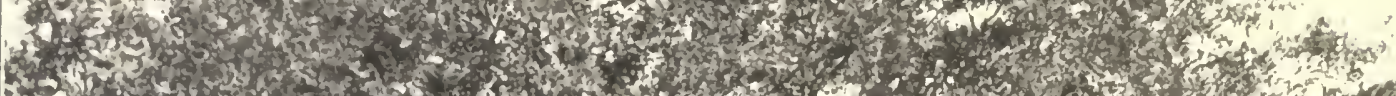

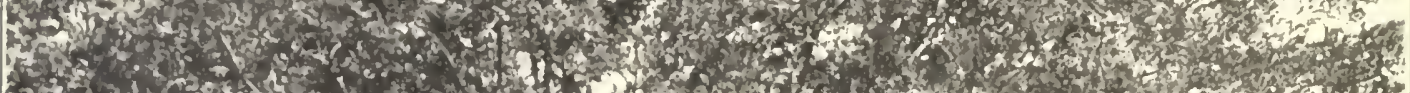

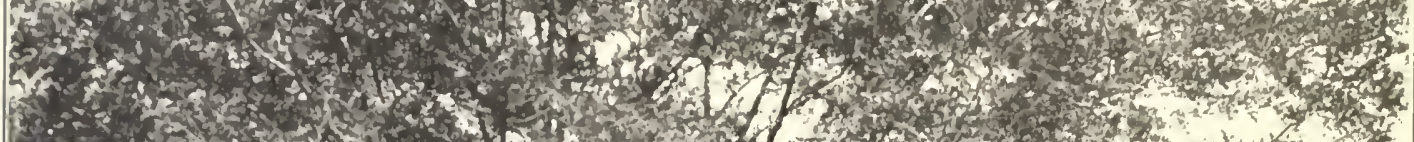

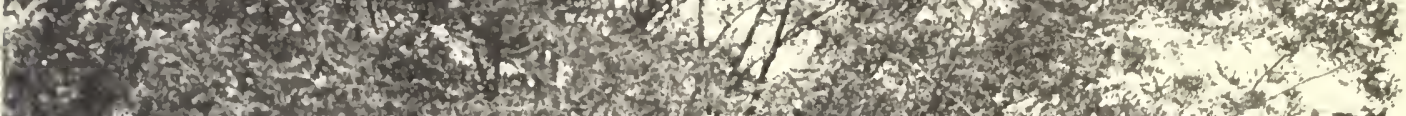

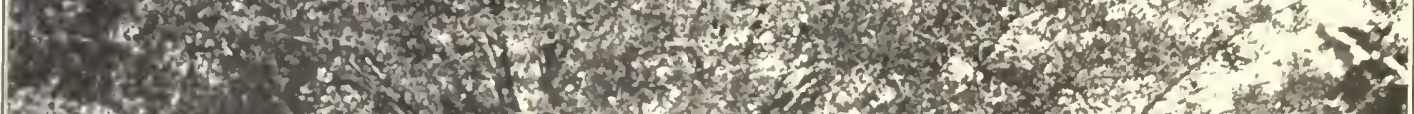

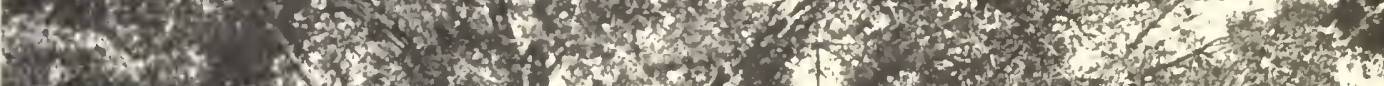

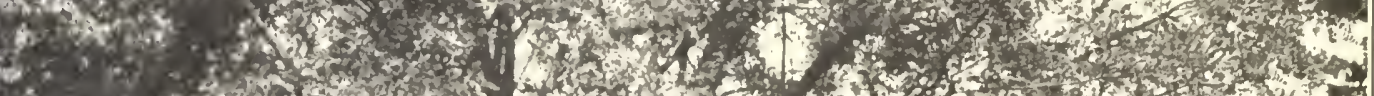

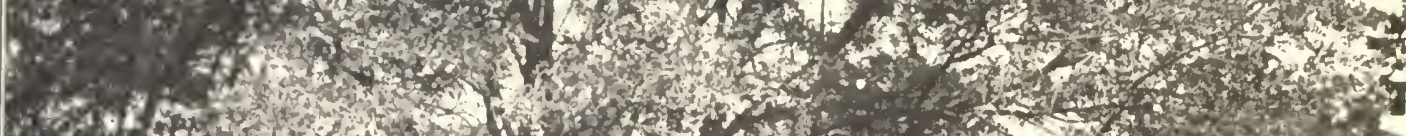

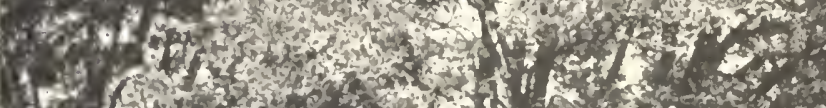

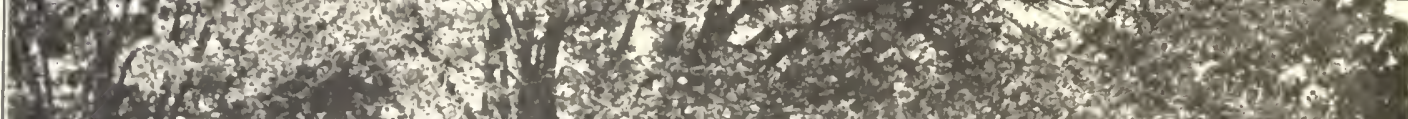
2.1.

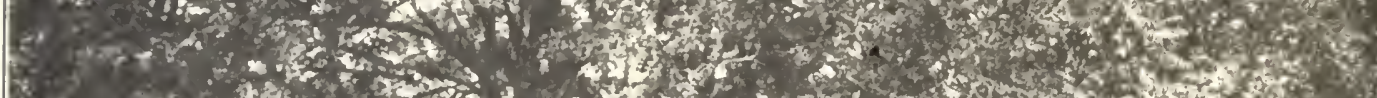

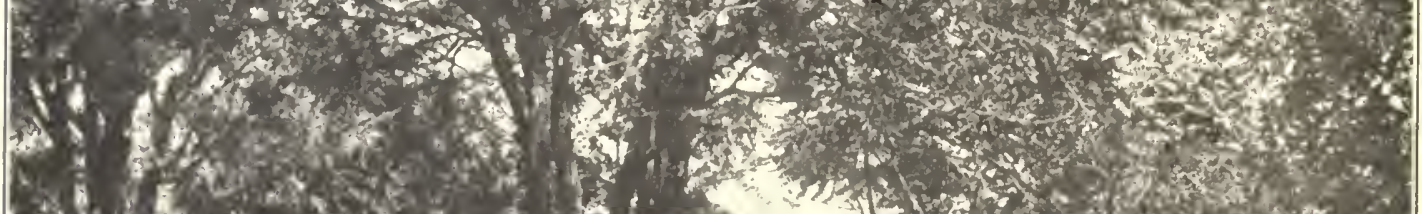
Lis

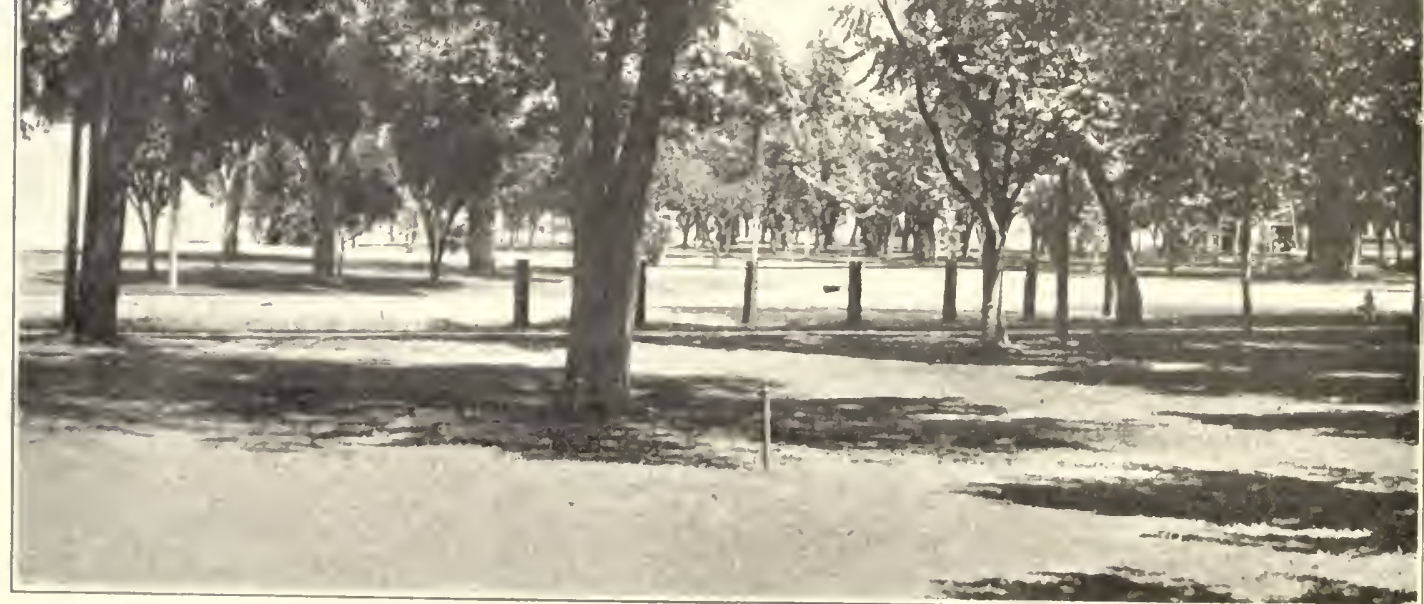

Plate 70. BLACK LOCUST. Merced.

the true acacias to Eastern United States which is known in Europe as the false acacia because of its resemblance to 
Strikingly characteristic of the tree are its dark-green, deeply"lobed leaves which are roundish in outline and from three to twelve inches broad. The young branches are bluish and rather stout in appearance. Big-leaf maple has an average height of sixty-five feet at maturity, grows rapidly, and is well adapted for street planting. In Berkeley it has done remarkably well, particularly on Piedmont avenue. It has also been successfully planted as a park tree in southern California. Because of its broad head, it needs considerable space for development.

\section{NORWAY MAPLE}

The Norway maple (Acer platanoides) has not been thoroughly tried out in California, but should do well in sections of the state where it will not be subjected to high temperatures and arid conditions.

Norway maple came from Europe, where it withstands city conditions well, and seems to have remarkable resistance to insect attacks. Its symmetrical, somewhat drooping shape, attractive yellow flowers, its broad dark-green foliage, turning to brilliant golden yellow in late autumn, makes it an attractive tree the year round. The growth is compact and vigorous, and it will thrive in almost any soil. It has a rich appearance, and a long leaf period, which makes it attractive on a street where other deciduous trees begin to show the waning of summer.

\section{MAYTEN}

The mayten (Maytenus boaria) is a graceful evergreen tree from Chile which does especially well along the coast and in southern California. It is a slender tree, rarely exceeding thirty feet in height, with delicate smilax-like foliage, which is effectively used for interior decorations. The flowers are small and greenish and the fruit scarlet.

The rounded top, pendent twigs, and graceful habit of this tree harmonizes well with other shrubs and trees on lawns. It has been little used as a street tree, but should prove useful on wide streets where evergreens are desired. There is a tendency for the central shaft to divide into several branches, but this may be remedied by pruning. 


\section{MULBERRY}

The mulberry is largely cultivated in many countries for its leaves which are the best food for the silk-worm. The white mulberry (Morus alba) is a native of northern China and Japan, and the black mulberry (Morus nigra) probably had its origin in Persia.

There is an interesting myth which accounts for the color of the fruit of the mulberry: Ovid relates that Thisbe was pursued by a lioness whose mouth was bloody from the recent slaughter of an ox. Pyramus, her lover, coming to the rendezvous and finding her blood-stained garments, thought her dead and killed himself at the foot of a mulberry tree; and Thisbe, returning, did the same. The poet states that the fruit of the tree till then was snow white, but when the lovers blood flowed over its roots and was absorbed into the sap the fruit took on a sable hue.

The Israelites regarded the mulberry as a medium of communication between God and man. David, when he inquired of the Lord how and when he should attack the Philistines, was told:

"Thou shall not go up; but fetch a compass behind them, and come upon them over against the mulberry trees. And let it be, when thou hearest the sound of a going in the tops of the mulberry trees, that then thou shalt bestir thyself; for then shall the Lord go out before thee, to smite the host of the Philistines."

A famous old mulberry tree in North London, under which 144 years ago it is said the American Declaration of Independence was first read in England, recently fell under the weight of its age. American Boy Scouts attending the Industrial Scout Conference recently held in London, visited the tree a few days before it fell and were told its history beneath its branches.

The red mulberry (Morus rubra), which is native to Eastern United States, is planted to some extent as a shade tree in Calfiornia. It grows to a height of about sixty feet, and has a wide-spreading habit. It furnishes abundant shade in a comparatively short time, but the litter made by the fruit makes it objectionable as a street tree. Its value as a highway tree is also questionable because of its irregular tendency of growth. 


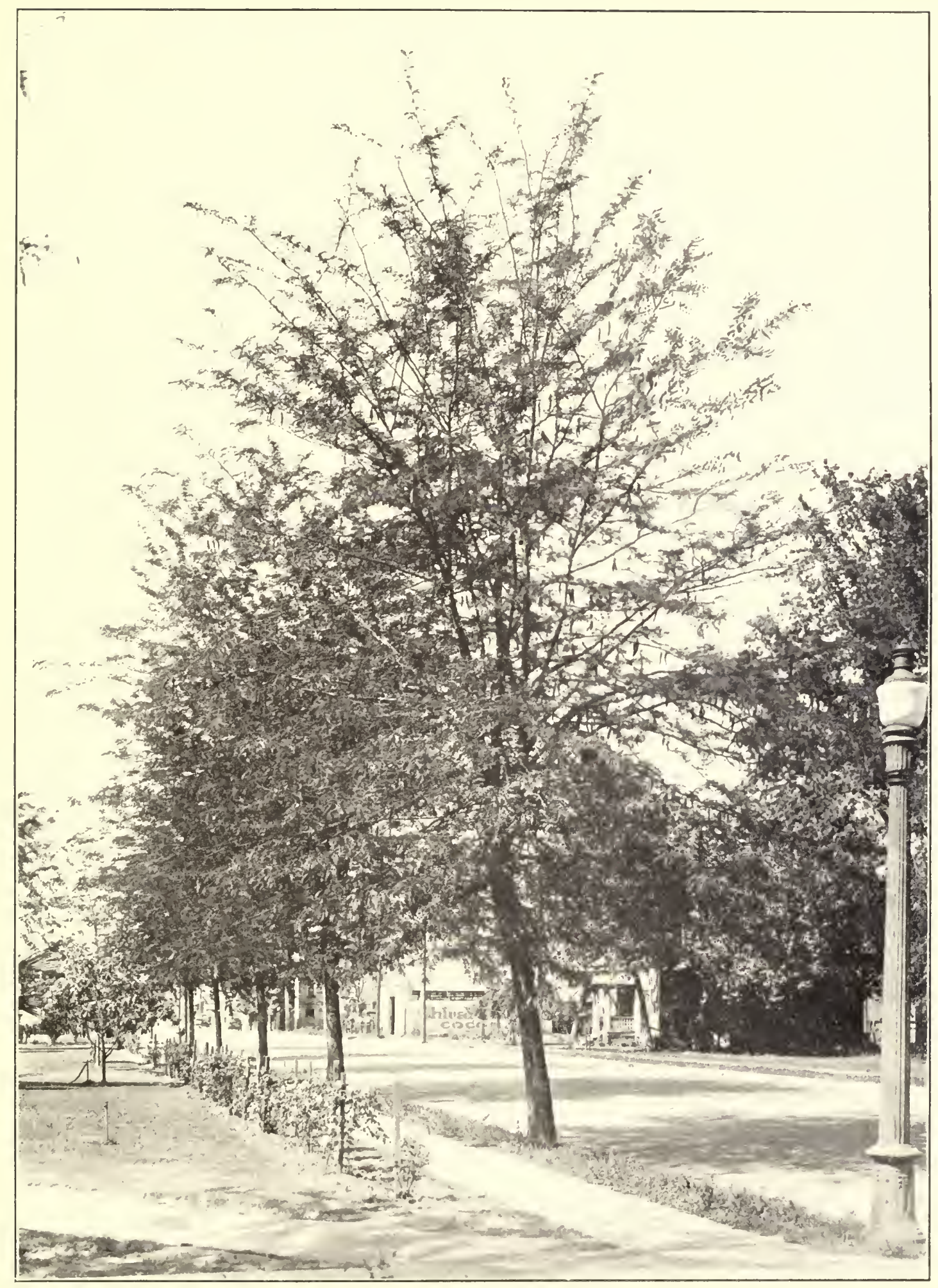

Plate 71. HONEY LOCUST. Visalia.

An Appalachian tree with finely-divided foliage, sharp thorns and fragrant greenisli flowers followed by large brown pods, 


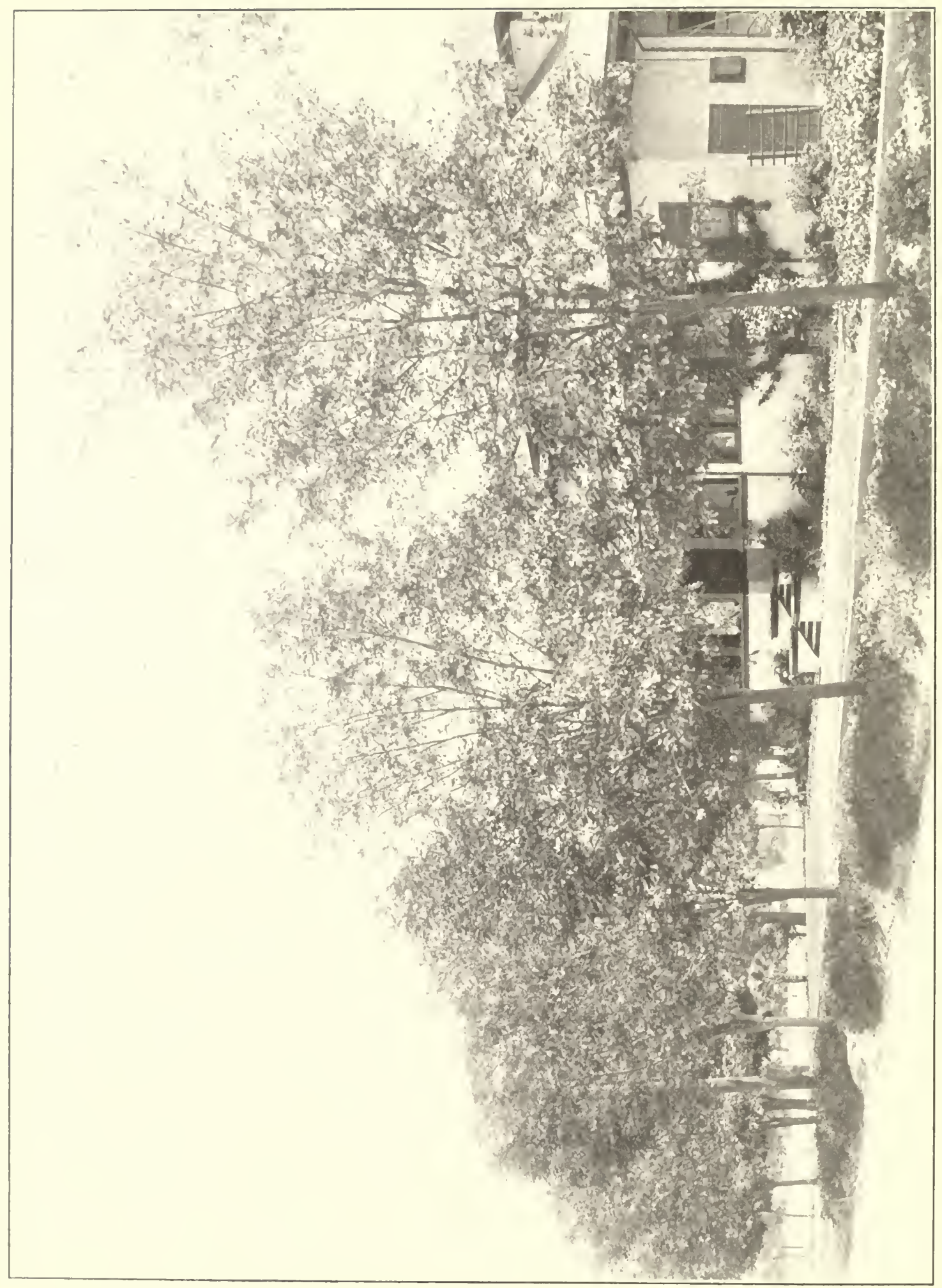




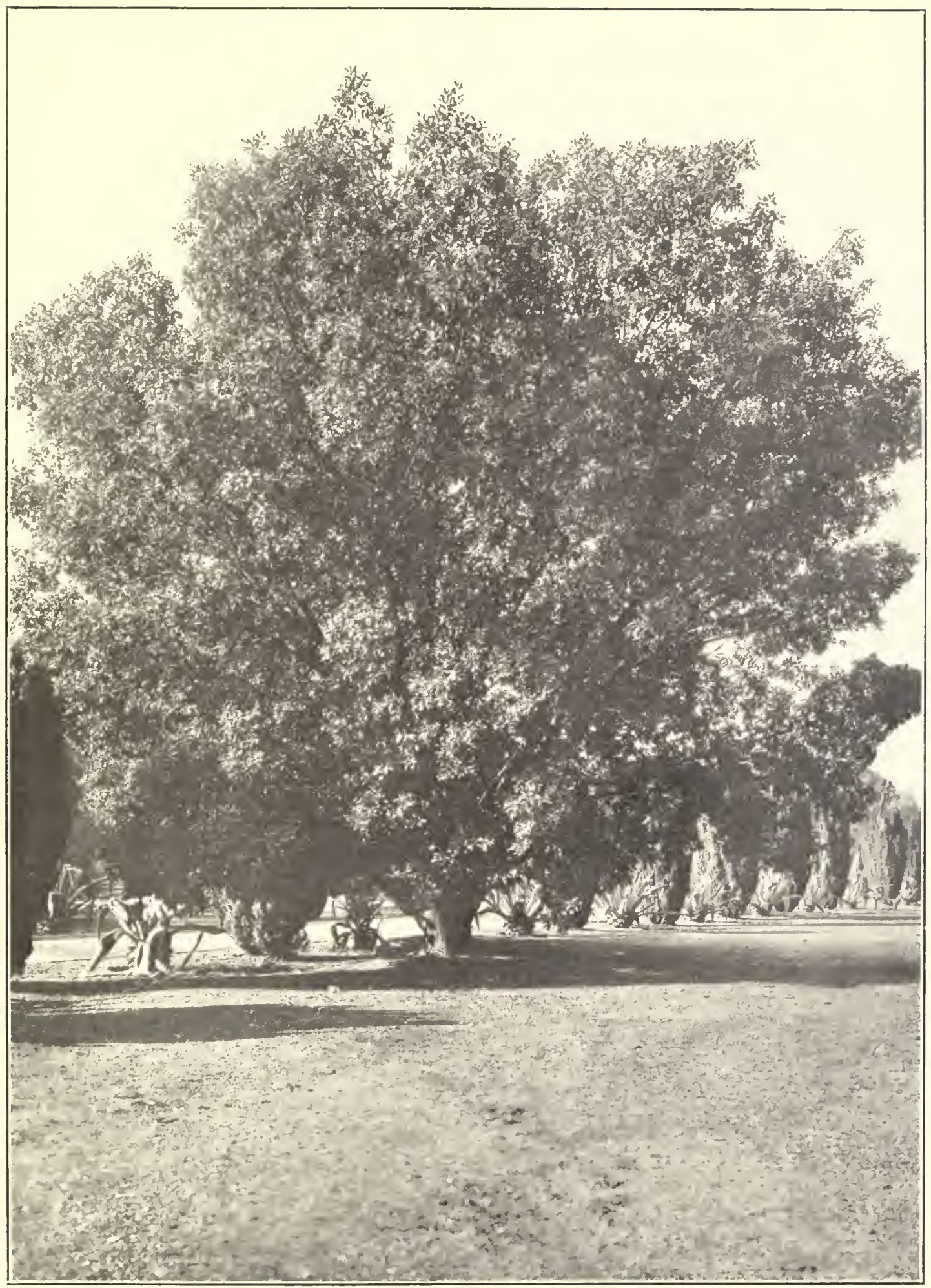

Plate 73. MADRONA. Sacramento.

"Captain of the western wood.

Thou that apest Robin Hood:

Green above thy scarlet hose,

How thy velvet mantle shows:

Never tree like thee arrayed,

O thou gallant of the glade. 


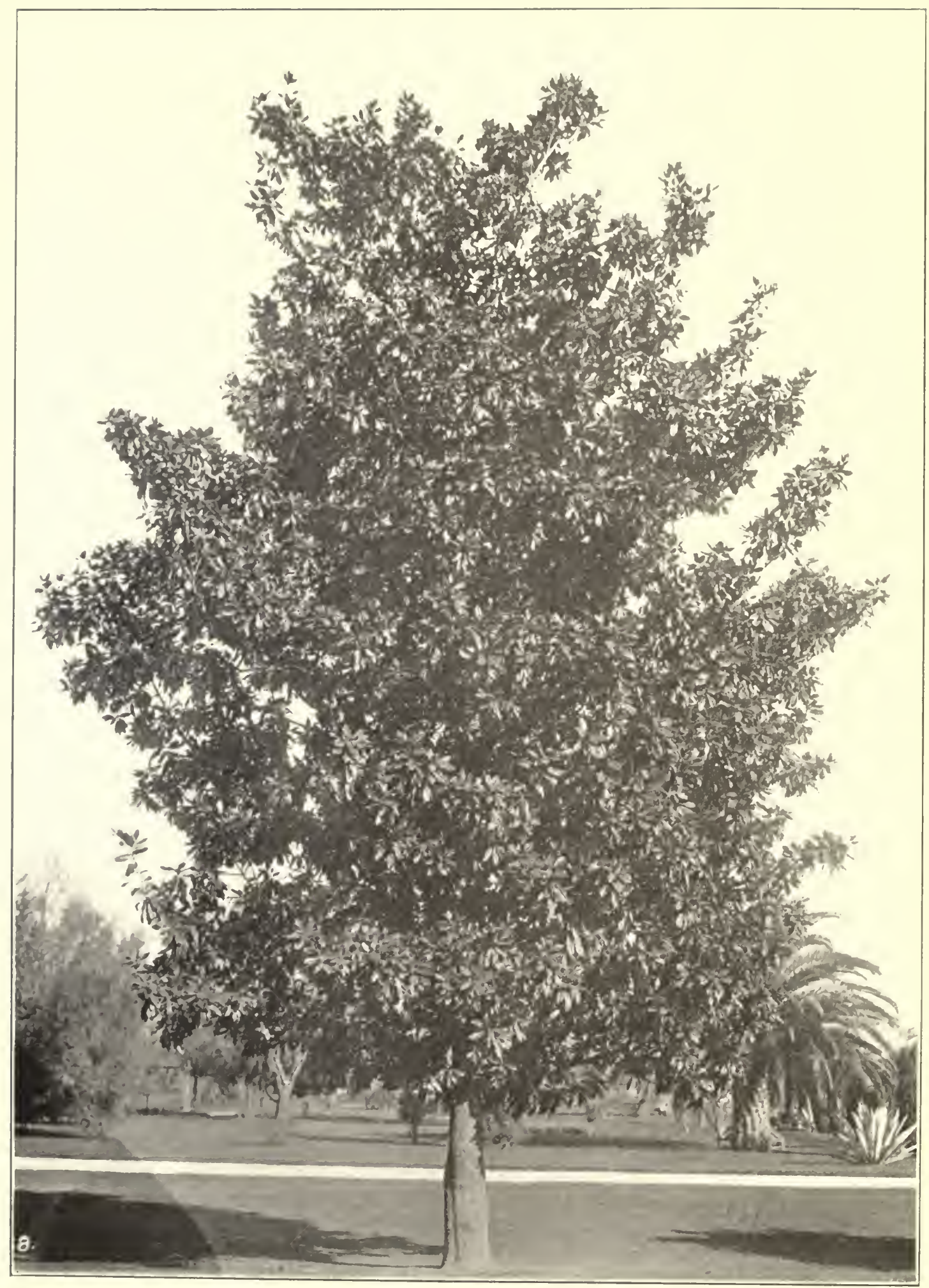

Plate 74. BULL BAY MAGNOLIA. Sacramento.

A beautulul tree from the Southern States which lines many strects and avenues in Califorria. 


\section{OAKS}

The oaks, which belong to the genus Quercus, embrace about 300 species which are distributed through the colder and temperate regions of the northern hemisphere and in the mountains of the tropics. They include both evergreen and deciduous trees and as a rule are of a stately habit with stout, widespreading branches. The leaves are medium sized usually more or less lobed. The fruit is a globular to oblong acorn set in a scaly cup.

The oak stands as a symbol of strength and endurance, and in England, particularly, is associated with the triumphs of Englishmen with "hearts of oak." In the days of old, the oak was closely associated with the worship of the gods and known as "Jove's own tree." The oak of Zeus at Dondona was believed to be the actual seat of the god whose oracular answers were given by the rustling of the winds through leaves and branches, by the murmur of the spring that flowed out from among its roots, or by lots drawn from an urn placed beneath it.

In Old Testament times Isaiah rebuked the Israelites for their idols under "every thick oak." It was "under the oak which was in Ophrah" that the angel of the Lord came and sat, and spoke to Gideon, telling him that it was he who was to save Israel from the hands of the Midianites. Jehovah appeared to Abraham beneath the oak tree in Mamre. At Shechem Joshua "took a great stone, and set it up there under an oak, that was by the Sanctuary of the Lord.

In mediaeval times the oak was held as a sacred tree and it was thought that a cross cut in its bark was a special protection against man and elfin enemies. The predominance of oaks is noticeable in reading of Britain's famous trees. This is due to their abundance and the special reverence with which they were held by the Druids, who cut sacred mistletoe from them with golden knives.

A famous English oak is the King's Oak at Woodstock, where it stands on the former hunting grounds. of Henry II. It was under the Parliament Oak at Clipstone Park that Edward I is alleged to have once convened a national assembly. An arrow glancing from an oak trunk caused the death of one English king Oak was used by the Northmen to build their long ships, and went into many enduring structures built by the Anglo-Saxons. In the "Faerie Queen" Spenser speaks of "the builder oak, sole king of forests all." 
The oaks are closely linked with Anerican history: On the banks of the river Osamece in Santo Domingo is an oak which is traditionally known as the tree to which Columbus tied his ship when he founded the colony "Hispaniola." The "Charter Oak" at Hartford, which fell in 18,6, concealed the charter of the Colony of Connecticut in a large cavity in its trunk until James II, who demanded it, was driven from the English throne. A large black oak stands near Haverstraw, New York, under which it is said "Nad" Anthony Wayne mustered his men in preparation for his brilliant charge on Stony Point. In the Friends' Cemetery at Salem, New Jersey, stands a massive oak the branches of which cover a quarter of an acre. Under it the soldiers of Washington's Continental Army were drilled in Revolutionary days.

Many years ago, Senator Charles Sumner sent an acorn from an oak which formerly overshadowed the old tomb of IVashington at Mlount Vernon to the Czar of Russia. This was planted in the palace grounds at Peterhof, and grew into a beautiful oak which has a tablet at its base bearing the following inscription:

"The acorn planted here was taken from an oak which shades the tomb of the celebrated and never-to-be-forgotten Washington; it is presented to His Imperial \1ajesty; the Emperor of all the Russians, as a sign of the greatest respect, by an American."

Senator Hitchcock gathered acorns from this tree and sent them to II ashington. One of the small oaks grown from these acorns was planted on April 6, 1904, in the White House grounds by President Roosevelt and is known as the Russo-American oak.

The city of Oakland, California, took its name from the oaks among which it was originally located. A few years ago, an oak was planted in the plaza before the city hall in memory of Jack London, who was a native of Oakland.

- Oaks are excellent street and ornamental trees. They are strong, durable, beautiful and have few insect enemies. There is a popular notion that oaks are slow growing trees, but it has been demonstrated that some oaks make as rapid growth as hard maple and other trees commonly planted. Some of the finest streets in Washington are planted with pin oaks, a species the worth of which has not yet been sufficiently recognized in this state. It is a handsome tree with finely divided deciduous foliage that takes on a scarlet and yellow 


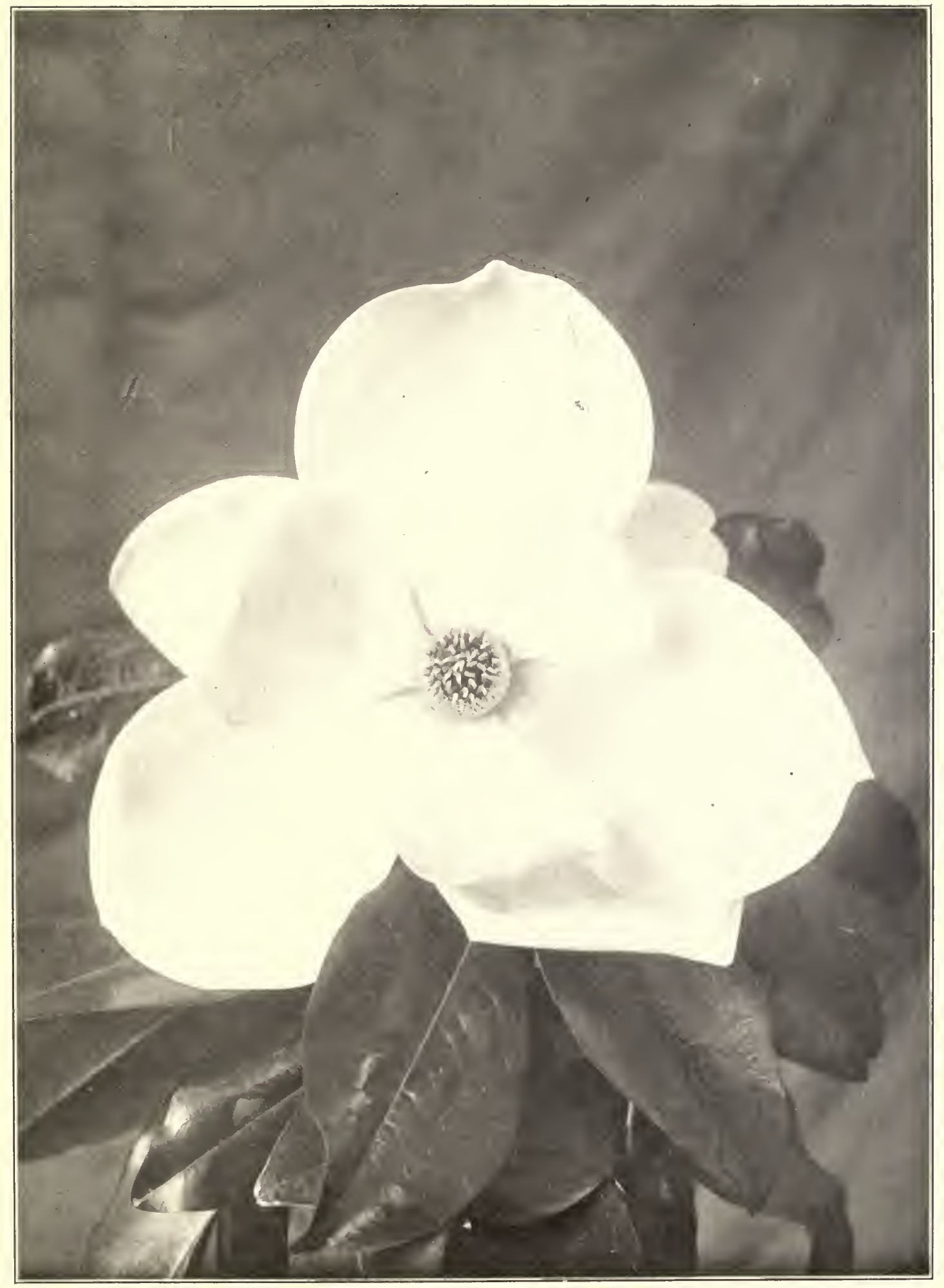

Plate 75. MAGNOLIA BLOSSOM. Sacramento.

"Faint was the air with the odorous breath of magnolia blossoms."

-Longfellow. 


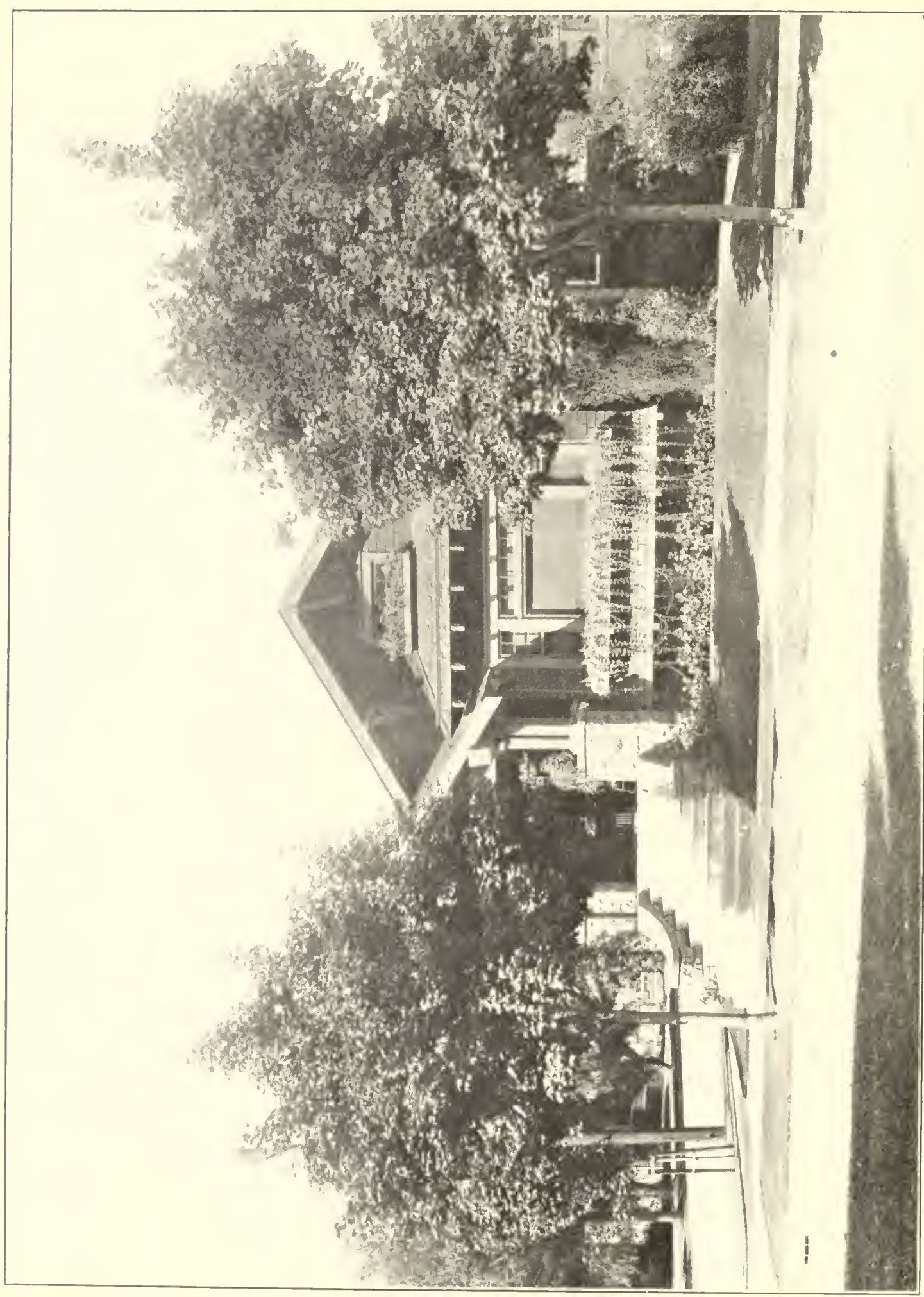

赔

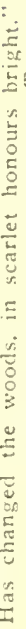


color in the fall. The dense branching of this tree causes some of the twigs to die, and these spurlike projections form the "pins" which give the tree its common name.

Oaks do not give as quick results as some species, but their permanence, stability and individuality recommend them for planting over many of the expressionless, quick-growing trees that are now used. On account of their spreading habit and irregular outline they should be given plenty of space in which to develop.

\section{VALLEY OAK}

Valley oak (Quercus lobata), also known as weeping oak from its graceful drooping sprays, grows naturally only in the Sacramento and San Joaquin valleys, and the valleys of the Sierra foothills and Coast ranges. It was discovered in 1792 by Spanish naval officers, and is often mentioned in the narratives of Fremont, Vancouver and other early explorers as a tree of graceful beauty.

It is stated by an early traveler that the Indians along the Rio Sacramento "have a very pernicious habit of lighting their fires at the bases of the valley oaks; and as they naturally select the largest, it was really a sorrowful sight to behold numbers of the finest trees thus prematurely and wantonly destroyed."

The most famous valley oak is the Hooker Oak at Chico, California, which was named in honor of Sir Joseph Hooker, who visited the tree in I 877. According to Gen. W. T. Sherman, 7000 men could be seated in the shade of this tree at noon. It has a height of 110 feet and a circumference of over twenty-eight feet. This tree is in a park deeded to Chico by the widow of Gen. John Bidwell.

The leaves of the valley oak, which are deciduous, are deeply lobed. The trunk of mature trees is dark-brown and divided by longitudinal fissures into broad flat ridges, broken horizontally into short plates. The tree usually divides twenty or thirty feet above the ground, the limbs spreading at wide angles and forming a broad head of slender branches hanging gracefully in long sprays. Valley oak does best on soils where the water table is close to the surface. It is a native species which deserves a place, and is recommended for planting in those parts of the state where it is one of the dominant 
features of the landscape. The trees should be planted from eighty to roo feet apart to allow room for the wide spread of branches in later life.

\section{CORK OAK}

The cork oak (Quercus suber). which forms extensive forests in Spain, Portugal and other sections of the Meditcrranean, is the source of the world's cork supply. The bark has a specialized cork tissue which produces cork at a much greater rate than any other tree. Cork was used by the early Greeks and Romans to float nets, but did not come into general use until glass bottles began to be used in the seventeenth century:

In its native habitat, cork oak grows on low hills, and attains its greatest size in cleep, rather moist loam. It is evergreen in character, and reaches a height of sixty feet and a diameter of four feet in the best situations. In 1860 acorns of the cork oak were planted in California, and from them came trees which have reached a diameter of two feet and a height of forty feet. Cork oak has no commercial value in this country, but makes a splendid ornamental, street or highway tree.

A number of fine specimens of cork oak are found in this state. They have the general outline of the native live oak, except that the leaves are more convex in shape. As the tree matures, it develops a corky bark which covers the trunk with large fold-like corky excrescences. Cork oak makes a symmetrical tree with rounded head, and when planted where soil and moisture conditions are farorable, makes a rapid growth. The largest cork oak in the state is situated at Campo Seco in Calaveras County.

\section{COAST LIVE OAK}

Coast live oak (Quercus agrifolia), also known as holly oak from the resemblance of its leaves to those of the holly, is a native tree of California that is found in the Coast ranges from Sonoma County to Southern California. It is a characteristic tree of the coast range valleys which it beautifies with low, broad heads. It attracted the attention of the early Spanish explorers who associated it with the fertility of the land. This is evidenced by the correspondence of the chain of Franciscan missions within the general range of this oak. 


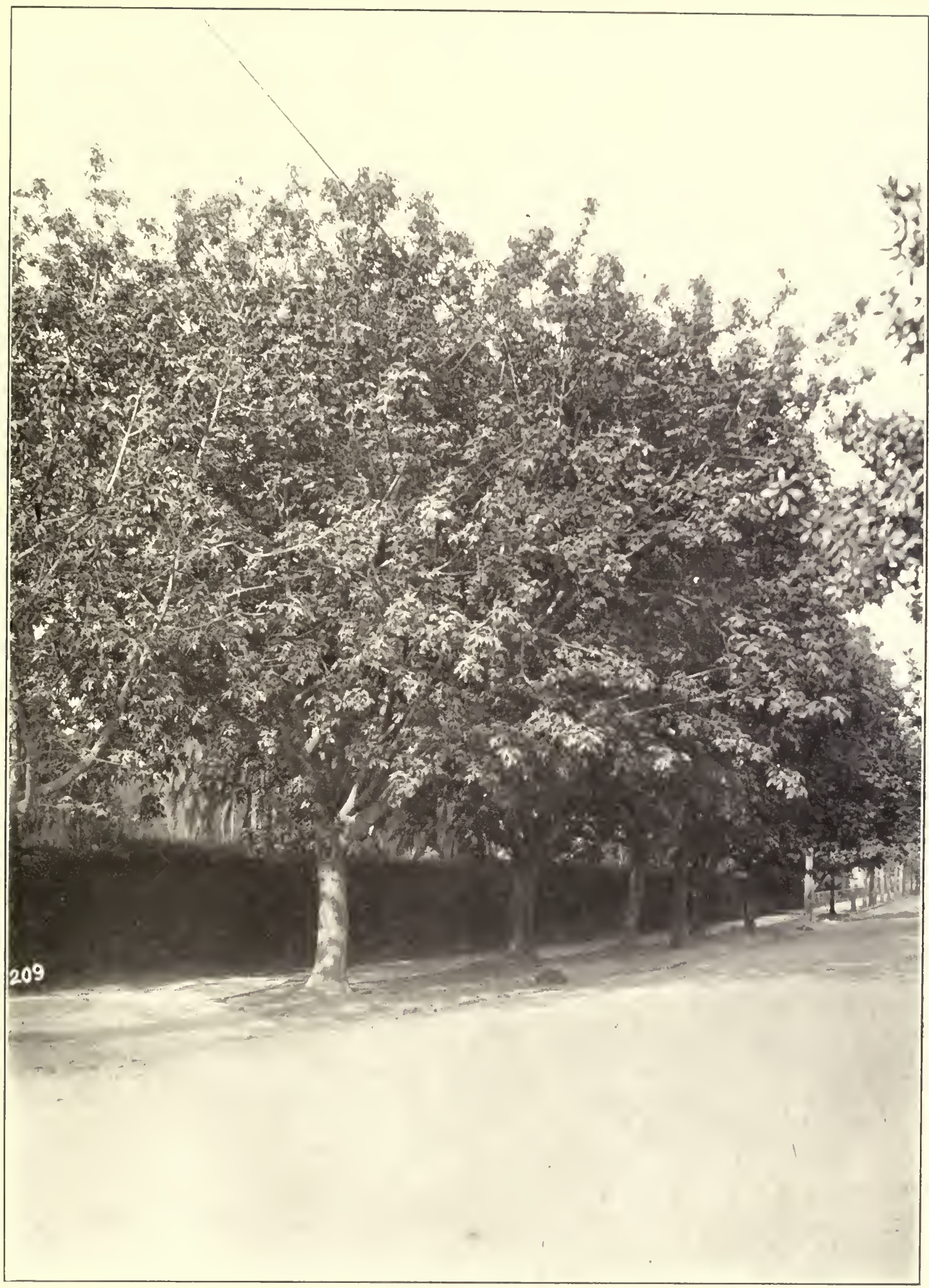

Plate 77. BIG-LEAF MAPLE. Berkeley.

A native tree that flourishes along the streams and creeks in the Coast Ranges. Like all the maples, its leaves change color in the fall. It is said that the maple leaf was chosen as an emblem of Canada since it endures the frosts of misfortune with added color and beauty. 


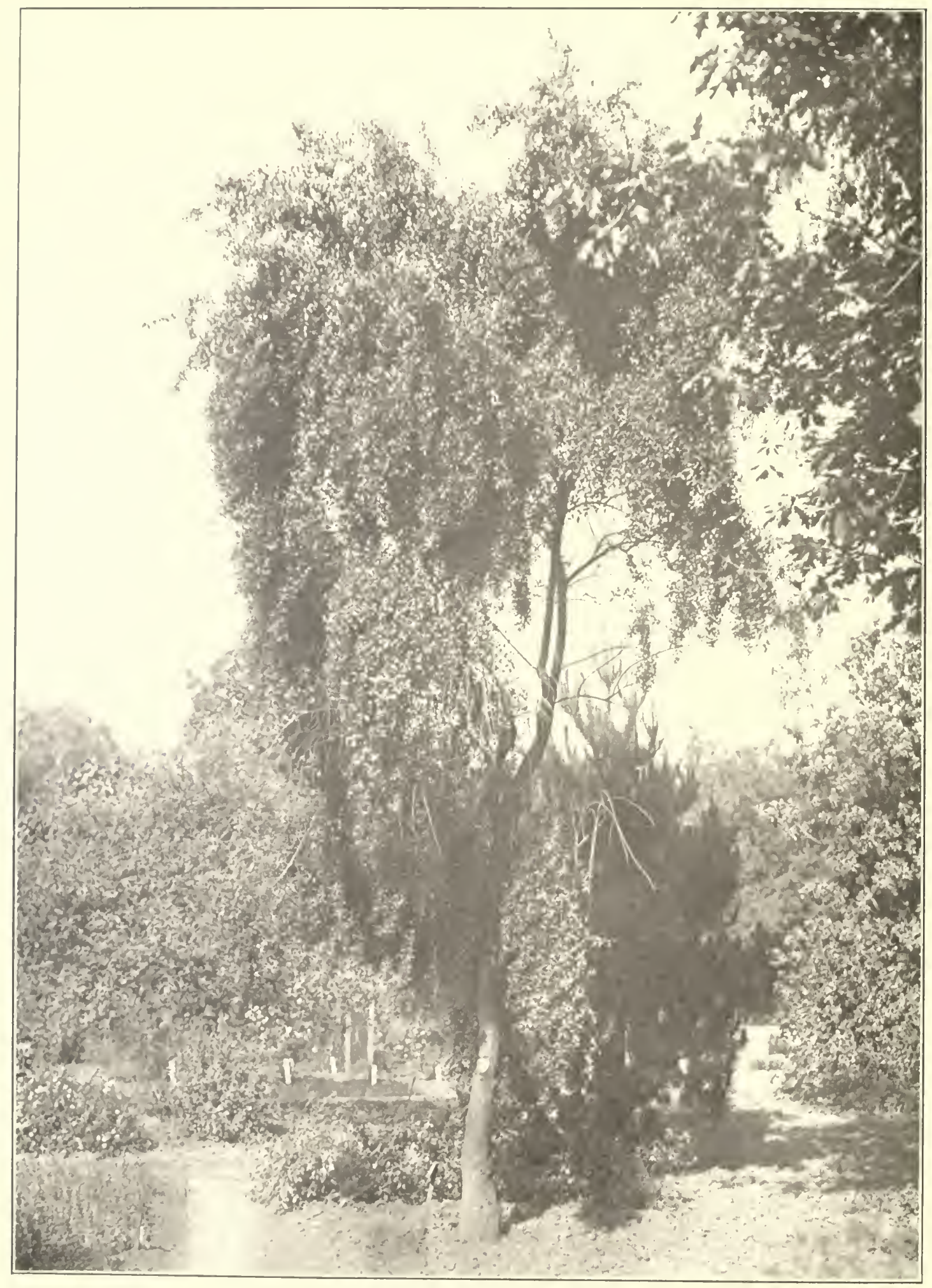

Plate 78. MAYTEN. Berkeley.

A graceful tree from Chile of an upright habit of growth and with myrtle-like leaves. 
California is justly proud of its oaks and there is none more beautiful than the Coast live oak. It is a hardy tree, from fifty to seventy feet high with a short trunk parting into wide-spreading limbs which often touch the ground. The trees on the campus of the University of California are very picturesque and very old. Among them is the famous Le Conte oak which was dedicated by the students to the memory of Joseph and John Le Conte, distinguished as scientists and beloved as teachers. The largest known Coast live oak is found in the Ojai Valley in Ventura County. Its crown is 105 feet across while the trunk has a diameter of six feet and eight inches at five feet from the ground.

Coast live oak is well adapted for a street or highway tree. It will make a good growth in a rich loam with a gravelly subsoil with plenty of moisture at the roots. In poor and dry soil it may prove a disappointment because of its slow growth. The young trees should be from four to five years old with sturdy root systems such as are developed in a nursery from several transplantings. Young trees taken directly from their native habitat will not do well.

About twelve years ago live oak trees were planted along the street in front of Sutter's Fort in Sacramento, where they have made remarkable growth.

\section{BUR OAK}

Bur oak (Quercus macrocarpa), often called mossy-cup oak from the hairy cup of the acorn, is one of the most picturesque of the forest trees of Eastern United States. It is a wide spreading tree with corky branches and very large, deeply lobed leaves, which are deciduous. This oak has not been widely planted in California, but should do well in the interior valleys, judging from the beautiful specimen in the Capitol Park at Sacramento.

\section{OLEANDER}

The oleander (Nerium oleander), is an old fashioned evergreen shrub which reaches a height of twenty feet or more in California, where it is extensively planted for ornamental purposes in parkings and lawns. There are many varieties, the blossoms of which range in color through various shades of red, pink, white and yellow. Unfortunately, oleander is subject to black scale, and all parts are poisonous if eaten. In spite of these disadvantages, 
however, it is desired by many on account of the heauty and fragrance of its blossoms. It can he planted on narrow streets where shade is a secondary consideration. but careful pruning is necessary to overcome its straggling habit. In some parts of the state it is used to alternate with the Canary Island date palm

\section{OLIVE}

The olive (Olea europaea) is a cultivated species that has been developed from the wild form which originated in Asia Minor. It was widely cultivated by the Phoenicians, Greeks and Romans. In Jerusalem there are olive trees standing in the Garden of Gesthsemane under which the Savior is supposed to have walked during the Night of Agony. The most famous of these trees was named "El Butini" and a tradition has long been held that when it fell the Turkish Empire would also fall. It was killed in 1915, when an unprecedented plague of locusts swept down upon Jerusalem, destroying every green thing for many miles around. Recent dispatches state that this tree has now fallen

The olive was early planted at the missions of California by the Franciscan padres, and from the trees grown there came a variety now known as the Mission. The original trees were grown at the San Diego Mission from seeds brought from Mexico.

The olive thrives in all soils provided they are deep and well drained. A clear dry atmosphere is essential else the tree is subject to the attack of the black scale. As a shade tree it is not satisfactory since the shape is such that it is very difficult to head it so that it will give any shade. As an ornamental tree it has desirable features on account of its distinctive style of growth, gnarled buttress and color of the foliage. It rarely exceeds twentyfive feet in height and has a very slow growth. It is most effective when planted as a unit on narrow drives or streets.

\section{ORCHID TREE}

The orchid tree, so called because of the resemblance of its flowers to orchids. is a rare tree from the tropics which is highly desirable for private grounds. It is very tender, however, and can only be grown in certain parts of southern California 


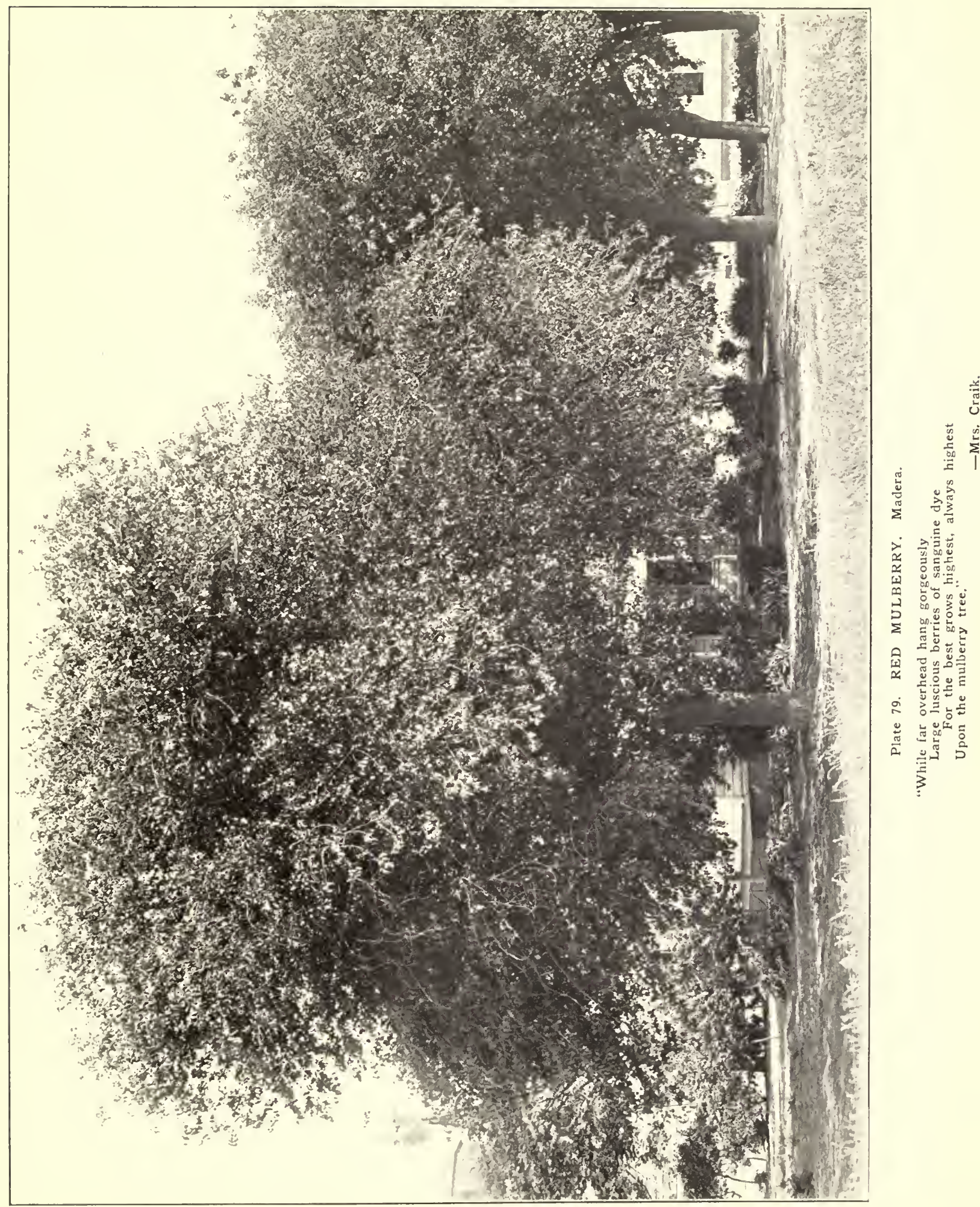




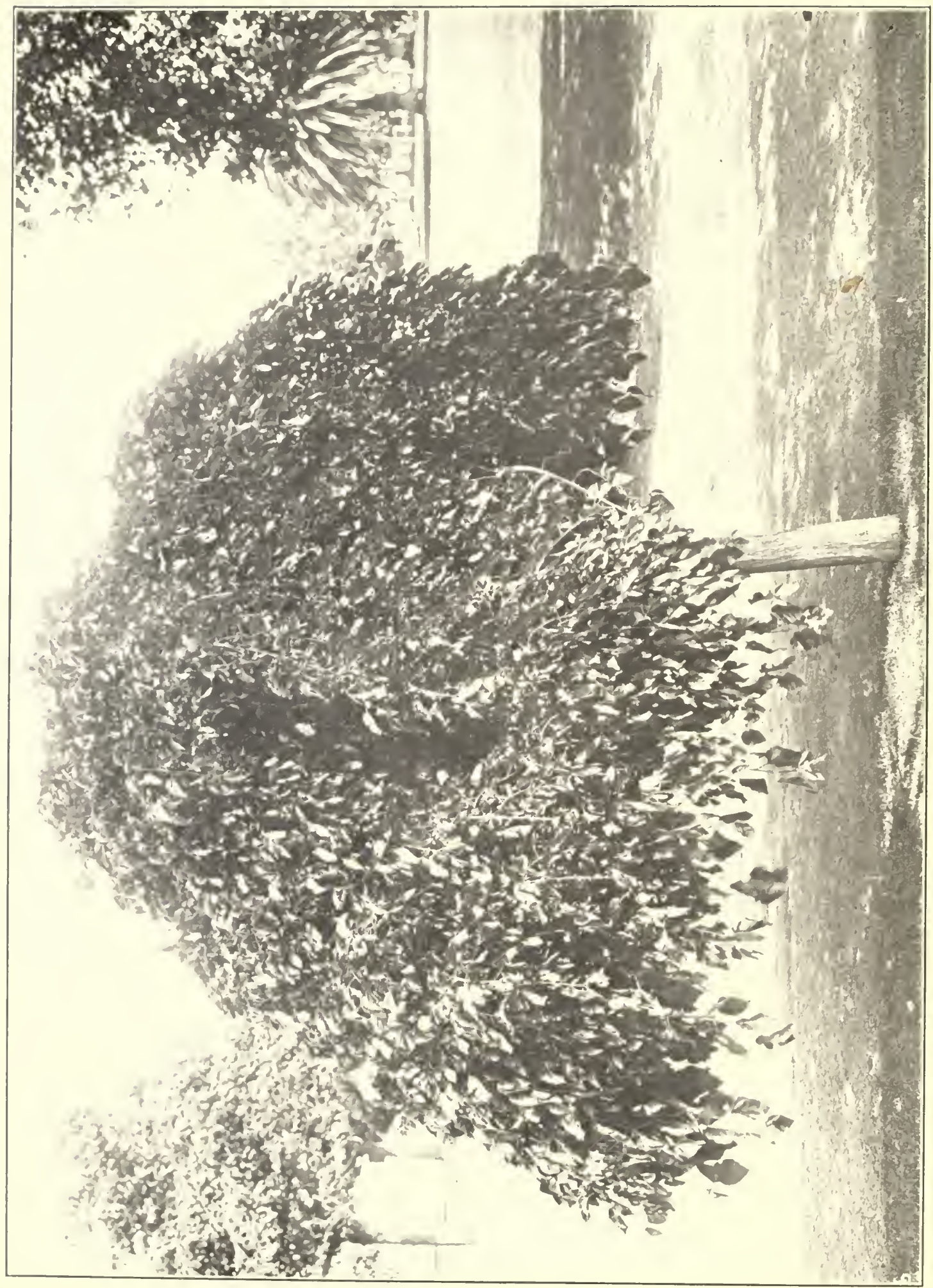


It has curious twin leaflets from which the generic name Bauhinia was taken in honor of two sixteenth century herbalists, John and Caspar Bauhin. The species (Bauhinia purpurea) from Southern Asia is a small tree, rarely excceding twenty feet in height. It bears flowers in great profusion. They are about three inches across and resemble orchids in color and shape. At a distance their color is deep lavender, but an examination reveals tones of mauve and purple, with a touch of white. This tree requires rich, well-drained land well protected from wind and frost, and special care until it becomes well established.

\section{PAGODA TREE}

The pagoda tree belongs to the genus Sophora, the Arabian name of a tree with pea-shaped flowers. The pendulous variety (Sophora japonica pendula), which originated in Japan, is one of the best weeping trees. It has long and slender pendulous branches with delicate leaflets that are dark-green above and lighter beneath. The pea-shaped flowers, which are small and cream colored, are borne in racemes about a foot long.

Sophora is scattered over the warmer parts of the two hemispheres with about twenty species, two of them becoming small trees in Texas. The Chinese use the pods and flower buds of an Asiatic species to make a dye which is used to dye white cloth yellow and blue cloth green.

The great attraction of the pagoda tree is its pleasing outline both in summer and winter. It thrives in well-drained sandy loam, but grows fairly well in rather dry soil. The weeping form can be increased by grafting on the common stock at the height of stem desired.

\section{PEPPER TREE}

The California pepper tree (Schinus molle), is a broad-headed tree with airy foliage which is widely planted in southern California. It has an abundance of coral red berries in the fall and winter which form a pleasing contrast with the bright green evergreen foliage of finely cut leaves.

The pepper tree is admired by tourists, but is falling into disrepute with orange growers due to its being a favorite host to the black scale. Many trees have been cut due to this cause, but there are still some beautiful avenues of this tree in Riverside and Los Angeles. 
As stated in Bulletin No. 4 , Street and Highway Planting, the following points should he kept in mind by any one considering its use:

1. The pendent habit of young growth means continued pruning.

2. The black scale infests it.

3. It needs very wide parkings on account of the irregularity of the trunk and the breaking of pavements.

+. It requires extra care when young, with staking and pruning, to encourage a gool form.

\section{BRAZILIAN PEPPER TREE}

The Brazilian pepper tree (Schinus terebinthifolius) has a rapicl sprcading growth and reaches a height of about forty feet. Its leaflets are longer than those of the California pepper tree, and the new growth is usually tinged with pink. It is strictly a southern California tree because of its susceptibility to frost

\section{PISTACHE}

The pistachio belongs to the genus Pistacia, one species of which produces the pistachio nuts of commerce, which are used in confectionery and flavoring. In Syria they always form an inportant ingredient at all wedding feasts. There are about twenty species, most of them being found in the Mediterranean region. The pistache was carly cultivated and according to Pliny was brought to Rome in the first century of the Christian era. It was introduced into the United States in is 53 , and has been extensively propagated at the Government station at Chico, California.

The pistache is a dry-climate tree and requires little moisture when once established in deep soil. The Chinese pistache (Pistacia chinensis) is one of the best species for ornamental planting. It is a round-headed tree about forty feet in height at maturity with stout branches bearing large dark green leaflets. The ends of the branches are covered with brilliant red foliage which appears like blossoms at a clistance. In the fall ruddy berry-like nuts are borne in large clusters.

\section{PITTOSPORUMS}

The Pittosporums, which belong to a genus by that name meaning "pitch seed," in allusion to the resinous coating of the seeds, embrace over one hundred evergreen species most of which are natives of the Australian 
group. They are shrubby plants which often attain the proportions of trees. Their growth is slow and their habit somewhat formal because of their upright, nonspreading form of growth. Several species have small, handsome flowers which add to their attractiveness in the spring. They are easily cultivated and make handsome single specimens on lawns, besides being very effective in grouping.

\section{VICTORIAN BOX}

Victorian box (Pittosporum undulatum), although often trimmed Ior a hedge, reaches a height of forty feet as a tree. It has rich green wavy-margined leaves, and fragrant whitish flowers in terminal clusters followed by showy yellow berries. It is used as an avenue tree in southern California because of the beauty of the foliage and the odor of the blossoms which resemble those of the orange.

\section{NARROW-LEAVED PITTOSPORUM}

Narrow-leaved pittosporum (Pittosporum phillyraeoides) has slender drooping branches, giving it the same habit as the weeping willow. The leaves are long and narrow and the flowers yellow and fragrant. It is a native of the deserts of Australia and is thoroughly adapted to dry situations in California. It reaches a height of about thirty feet.

\section{POPLARS}

The poplars belong to the genus Populus, and as the name indicates have a wide popularity for planting on account of the ease with which they are propagated and the rapidity of their growth. The genus embraces some twenty-five species of which eleven are found in North America. In the extreme north there are great forests of poplars and they are also found abundantly all through the northern hemisphere particularly along stream courses.

Many of the species contain fragrant balsam in the buds which is accounted for in a Grecian myth. The story goes that Jupiter, angry at Phaethon for his reckless driving of the Chariot of the Sun, hurled him into the river Po where he was drowned. His unhappy sisters, the Heliades, mourning his fate upon the river bank, were changed into poplars, and their tears into its balsam. 
Legend tells us that the Cross was made of Aspen, one of the poplars, and as is so heautifully told by Mrs. Hemans:

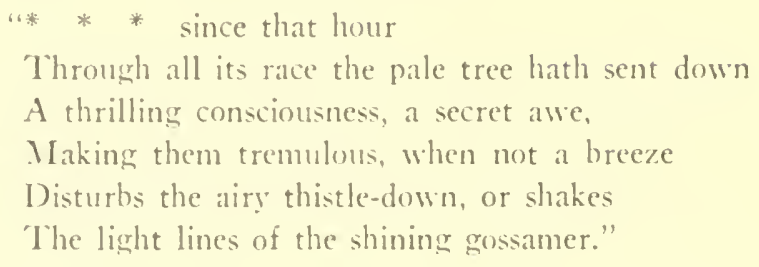

The constant agitation of the foliage of the aspen by the least breath of wind is due to the length and flattened form of the leaf-stalk. It has no stability at the point of juncture of leaf and stalk which causes the leaves to quiver constantly, no matter how faint the breezc. 'The rustling noise, as of a purling stream, is produced by the friction of the leaves on one another.

In England poplars are commonly planted wherever a quick screen is requircd, a practice concerning which Evelyn says:

"Wc may recommend them to such late builders as seat their houses in naked and unsheltered places and that would put a guise of antiquity upon any new inclosure, since by these, whilst a man is on a royage of no long continuance, his house and lands may be so covered as to be hardly known on his return."

So rapid is the growth of poplars that in some European countries a plantation of these trees made on the birth of a daughter is expected to grow into an ample dowry for her marriage.

The cottonwood, the largest of the poplars, is associated in the United States with the history of the Middle West. Up to a few years ago there stood a giant cottonwood near Wilmette, lllinois, which was known as the Black Hawk tree. Black Hawk often assembled the Indian chiefs under his command around this tree, and many of his campaigns against the whites were planned beneath its shade. At the time this tree was destroyed by a malicious act it was 130 feet in height and measured twelve feet at the base.

On the Capitol grounds at Topeka, Kansas, stands a cottonwood under which were mustered the Twentieth Regiment of Kansas Volunteers which made such a splendid record in the Philippines under General Funston. 

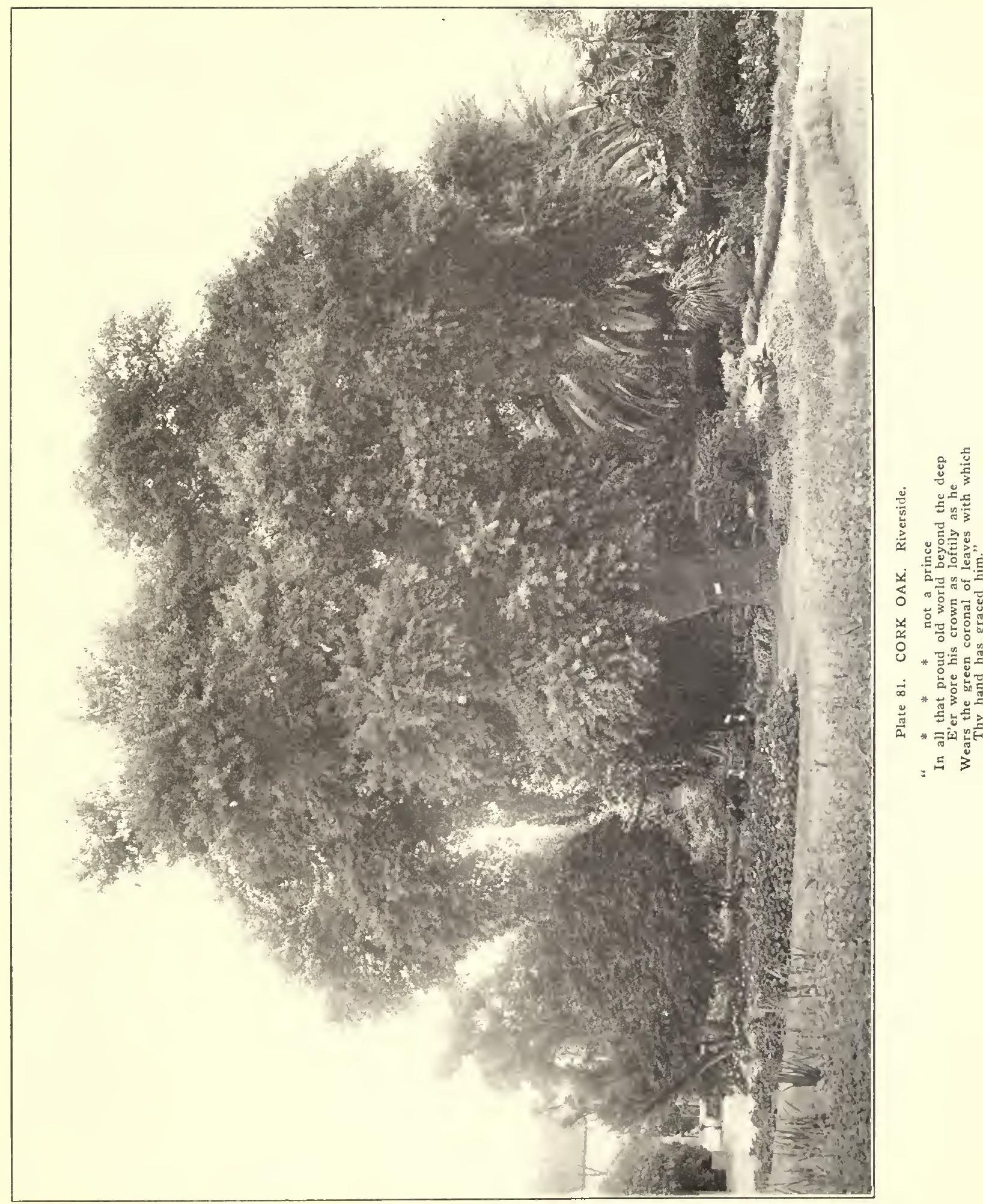


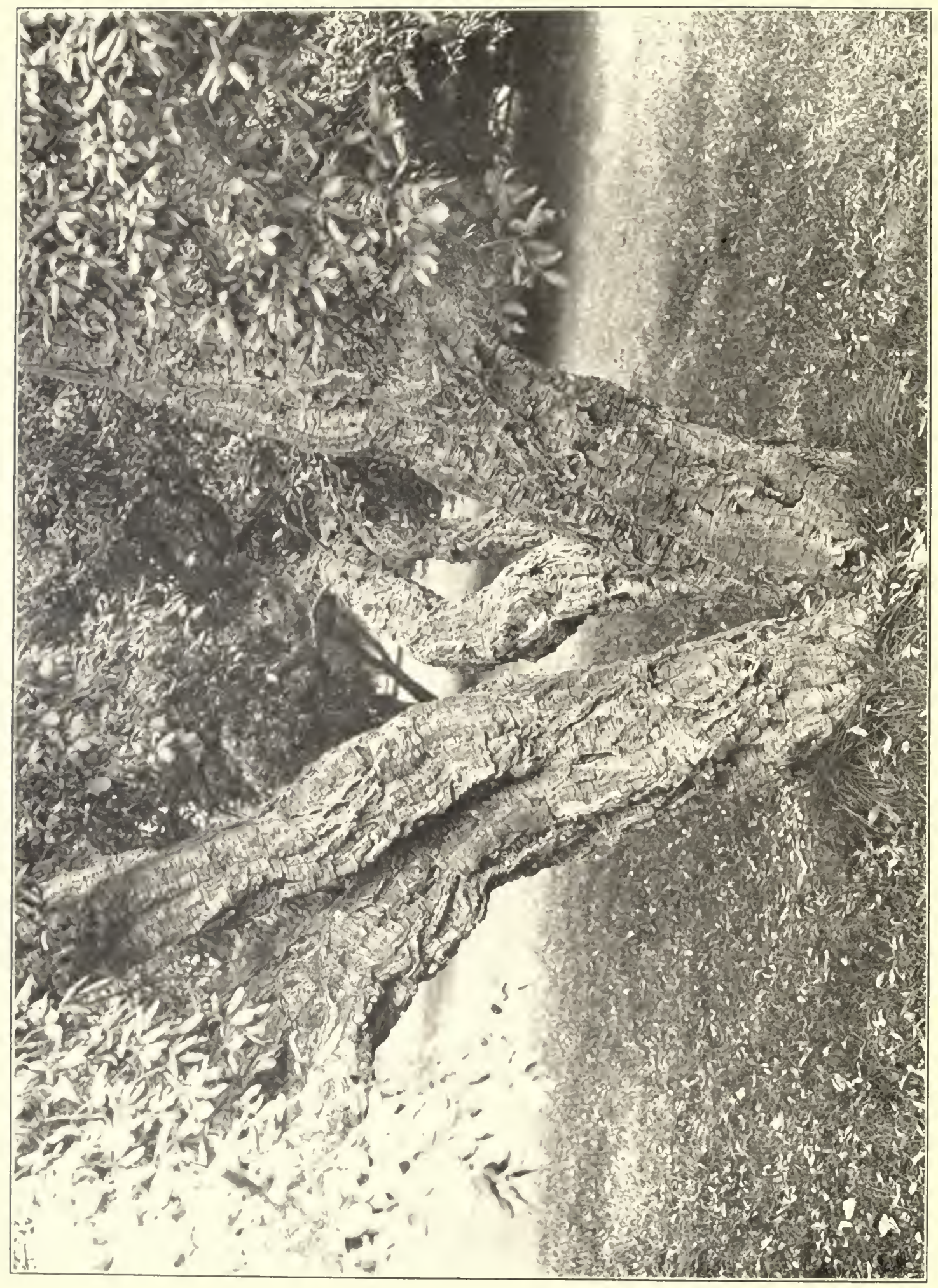




\section{CAROLINA POPLAR}

The Carolina poplar (Populus deltoides carolinensis) is a very rapid growing tree with large leaves which is easy to transplant and which will thrive under a wide variety of soil conditions. For this reason it is widely planted although it has many undesirable features which ordinarily makes the choice of other species preferable. It reaches maturity quickly, breaks easily because of its brittle wood, and suckers badly. It is particularly bad for street planting since its fine roots penetrate the slightest crevice in a sewerpipe in its vicinity and fills them with a network of fibers which soon stops the flow of water. Some towns have passed ordinances that forbid the planting of the tree because of its objectionable habits. If other trees will grow, the Carolina poplar should not be planted If used at all, it should be planted with the idea of cutting the trees out in a few years.

\section{LOMBARDY POPLAR}

The Lombardy poplar (Populus nigra italica) derives its name from its abundance on the banks of the Po and other rivers in Lombardy. It was brought into Italy from the Himalayas by way of Persia where it has been planted along the roads from very early times.

Most of the broad-leaved deciduous trees have rounded contours. The Lombardy poplar stands almost alone in the remarkably erect, or fastigiate habit of growth of its branches which are of almost equal length at the base and at the top of the tree, and which point upward at a sharp angle from the trunk. It is called the "exclamation point" in landscape architecture because of its tall pyramidal form which is utilized to mark the position of houses or serve as sentinels at the entrance of parks. When planted close together the trees make an excellent wind-break because of their low branches which form a wall of foliage against drying winds.

Early in the spring the flowers appear as long catkins, dangling on the bare branches. While the catkins are having their day the leaf buds are swelling. When they burst, the two outer scales turn red and the emerging leaves are curled up on their faces from margin to margin in two coils which as they roll back expose the shining, bronze face of the little leaf. Soon the 
little triangular leaflets come forth on their long leaf-stalks, and glint cheerfully in the sun, which led the poet Cornwall to say:

"The poplar there

Shoots up its spire, and shakes its leaves

In the sun."

Lombardy poplar should never stand alone, but should be placed so that the row of vertical green plumes may form a contrast with some horizontal line such as a railroad embankment, or the arch of a viaduct.

\section{CHINESE POPLARS}

These poplars (Populus chinensis), (Populus simonii), and (Populus tomentosa), that have recently been introduced from China, give promise of making very satisfactory growth for quick windbreak protection. The first has an upright habit similar to the Lombardy poplar but with more graceful leaves. The second has glossy leaves which are of unusual shape. The third, as its name implies, is distinguished by the silvery tone of its leaves. This tree has made remarkably rapid growth at Berkeley and Chico.

\section{PRIVETS}

The privets embrace about thirty-five species of small trees and shrubs from Europe, Asia and Australia. They are valuable for their hardiness and are extensively used for formal planting especially for hedges and screens.

The Japanese privet (Ligustrum japonicum) is a large shrub or small tree with leathery, dark-green leaves and white flowers which have a sickly sweet fragrance. They are followed late in the summer by dark-blue berries. This privet is good for a tall hedge, but also makes a handsome flowering tree. When grown as a tree care should be taken to select specimens from the nursery which have unbranched leaders for at least seven or eight feet, since the head is formed very low after branching begins. It needs a wide parking on account of its spreading crown which gives abundant shade at maturity. Constant care is needed to keep down suckers which tend to spoil the shape of the tree. 


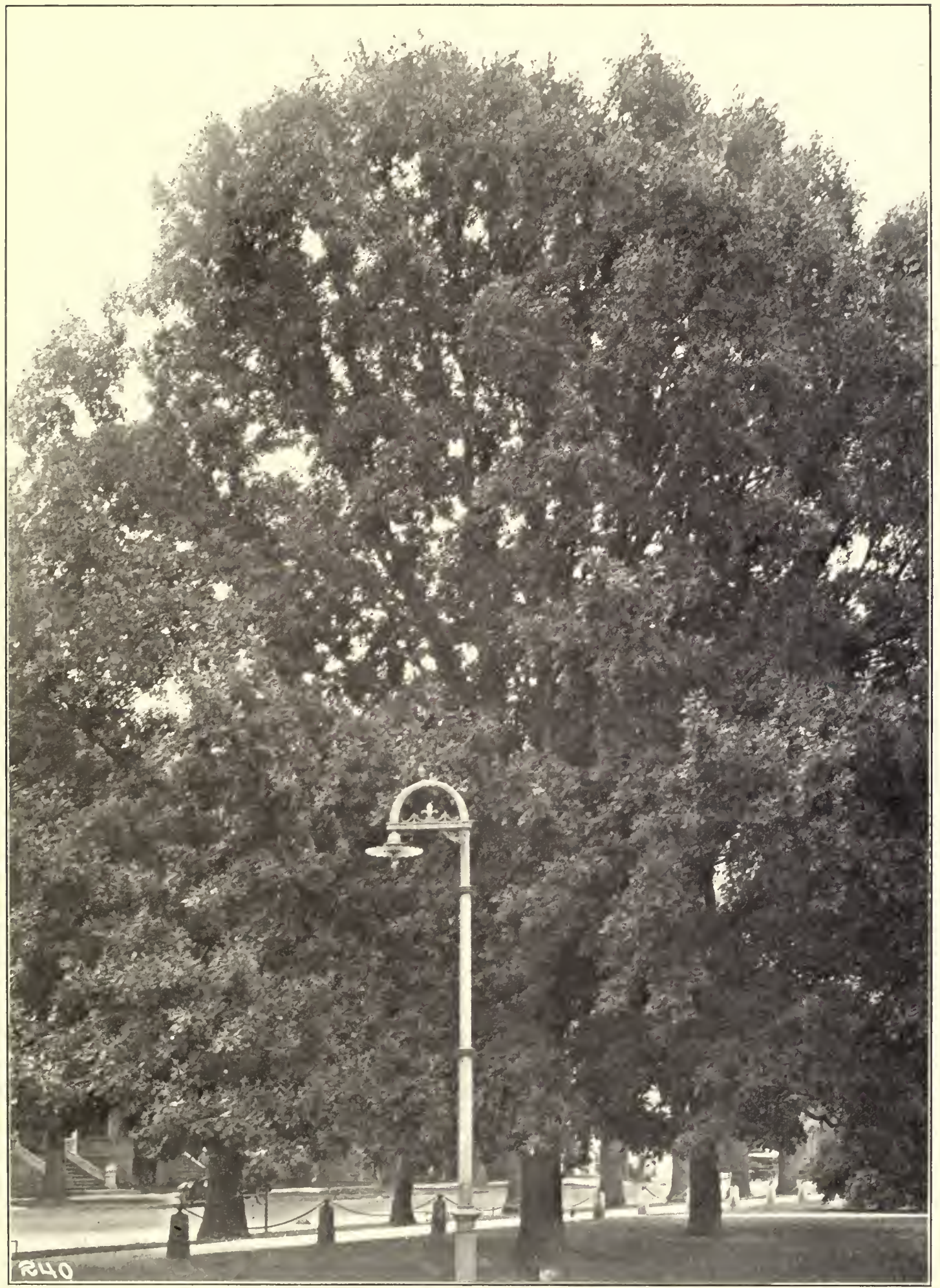

Plate 83. BUR OAK. Sacramento.

One of the finest of the Eastern oaks with wide spreading branches and large deeply lobed leaves. The acorn cups are fringed and bur-like. 


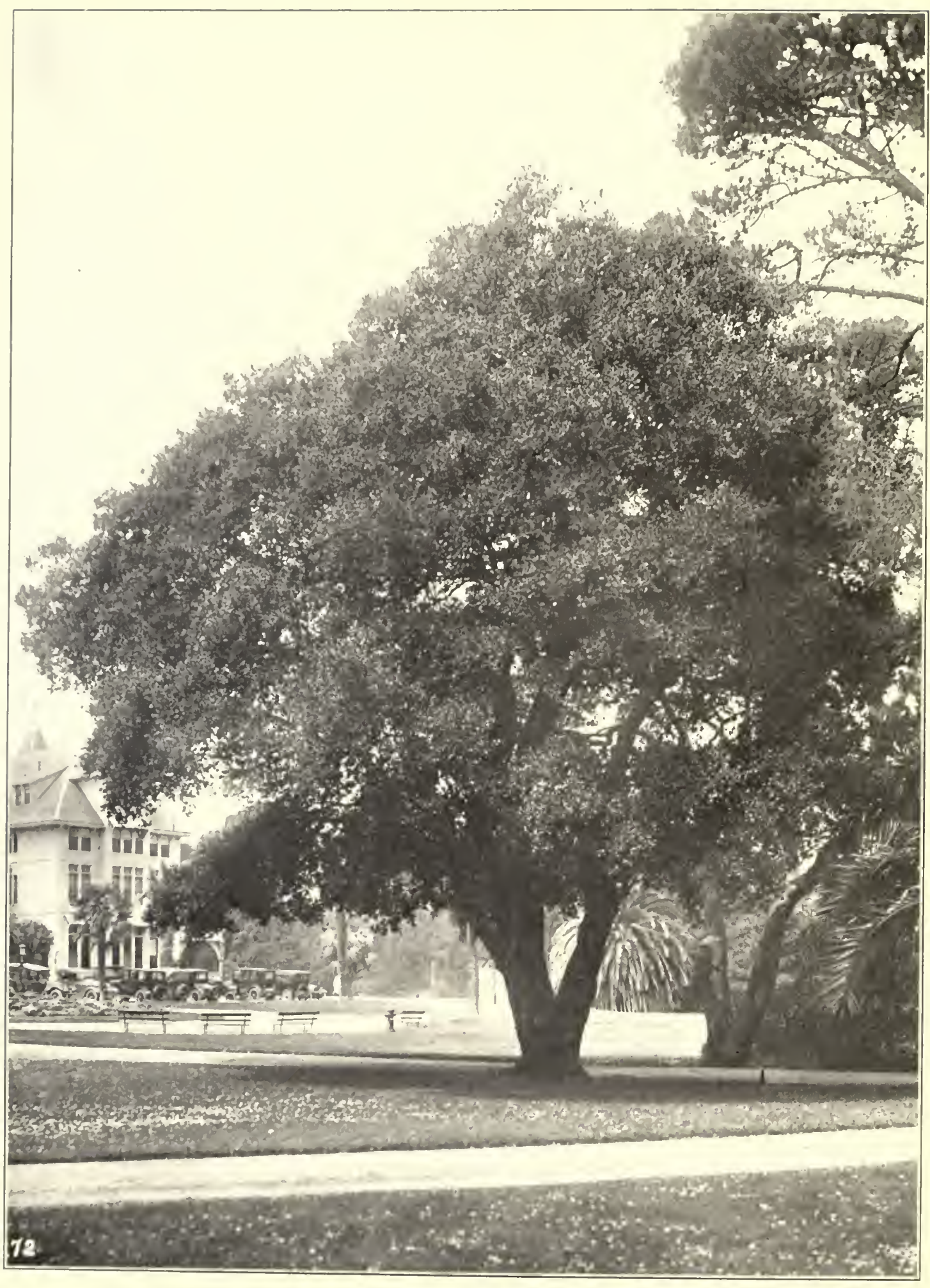

Plate 84. CALIFORNIA LIVE OAK. Del Monte

"And the tair oak, whose leafy dome affords

A temple where the vows of happy love

Are registered."

-Shelley. 


\section{RED-BUD}

The red-bud, commonly called the Judas tree, takes its generic name Cercis from a Greek word for a weaver's implement to which its fruit bears a fancied resemblance.

There are seven species of Cercis in the world, three of which occur in North America. The eastern species reaches a height of forty to fifty feet, while the western species are smaller and more shrub-like. All species are very ornamental with a profusion of bright pink pea-shaped flowers that adorn the black-barked branches before the leaves appear. The sudden change from bare branches to those covered with beautiful blossoms swinging on little delicate stems is very striking Californians go many miles in the springtime to see the red-bud in bloom and to gather its blossoms.

After the blossoms go, the heart-shaped leaves and flat brown pods appear. The hold of these pods upon the limb from which they hang is very slight, so that a mere breath is sufficient to make them fall to the ground.

The California species (Cercis occidentalis) is rarely over fifteen feet in height. It is often cultivated as an ornamental tree, and is used to good effect in grouping with other small trees and shrubs. It is easily handled and thrives best on well-drained soils in semishaded situations.

\section{RUBBER TREES}

The rubber trees belong to the genus Ficus of which the curious banyan tree, the sacred fig of India, is a member. This tree has a peculiar form of growth, its branches sending out aerial roots which become multiple trunks when they reach the ground. Lateral branches are sent out from these trunks and the tree continues to expand outward until it becomes a forest in itself, the haunt of birds and monkeys who feed on its fruit, a sort of red fig, the size of a cherry. There is a banyan tree in the botanical gardens of Calcutta which has a central trunk over 50 feet in circumference and about 200 progressive trunks. On an island in the Nurbudda River in Western India is a tree with 350 large trunks and 3000 smaller ones under which an army of 7000 men is said to have encamped.

The Hindus regard the banyan tree as a symbol of the Deity due to its long endurance and overshadowing beneficence. Solemn festivals are held 


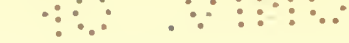

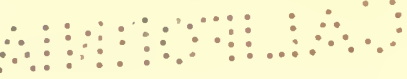

heneath its branches, and fakirs and anchorets often seek religious solitude in its leep and grateful shade.

\section{MORETON BAY FIG}

The Mloreton Bay fig (Ficus macrophylla) is a native of Australia, where it forms one of the finest avenue trees in some of the cities. It makes a magnificent tree which assumes large proportions in height and dianneter in California. It is remarkable for the fantastic development of its buttressed roots which resemble the snake-like roots of the rubber tree which vields the India rubber of commerce. The foliage is evergreen in character and consists of bright glossy green leaves. Its large spreading head makes the Noreton Bay fig desirable for street planting, but care should be taken to space the trees at least eight feet apart to allow for the wide extension of the branches. It should not be planted in locations subject to heavy winds which may break its heavy limbs. Due to its sensitiveness to frost, it is not recommended for planting outsicle of southern California.

\section{INDIA RUBBER TREE}

The India rubber tree (Ficus elastica) is much grown as a house plant. but will reach a large size as a tree when planted in favored localities. It reaches a height of 100 feet in the tropics and has a wide-spreading habit. The leaves, which grow to twelve inches in length, are very dark, gloss! green and have a leathery texture. This tree which is a native of Assam. vields the rubber called "Rombong" of comnerce. Its octopus-like appearance given by its deep buttressed roots makes it a great attraction for tourists. When planted as an ornamental tree in California, it should be given gool soil and plenty of moisture. It will not do well except under very favorable climatic conditions, since it is naturally a tree of the tropics.

\section{SILK OAK}

The silk oak (Grevillea robusta) takes its generic name after Chas. F. Greville, an English patron of botany. It is an Australian tree that has no relation botanically with the true oaks, but which is commonly called silk oak because of the silky-like appearance of its wood which is hard like that of oak. It is sometimes erroneously called the gorilla tree. 


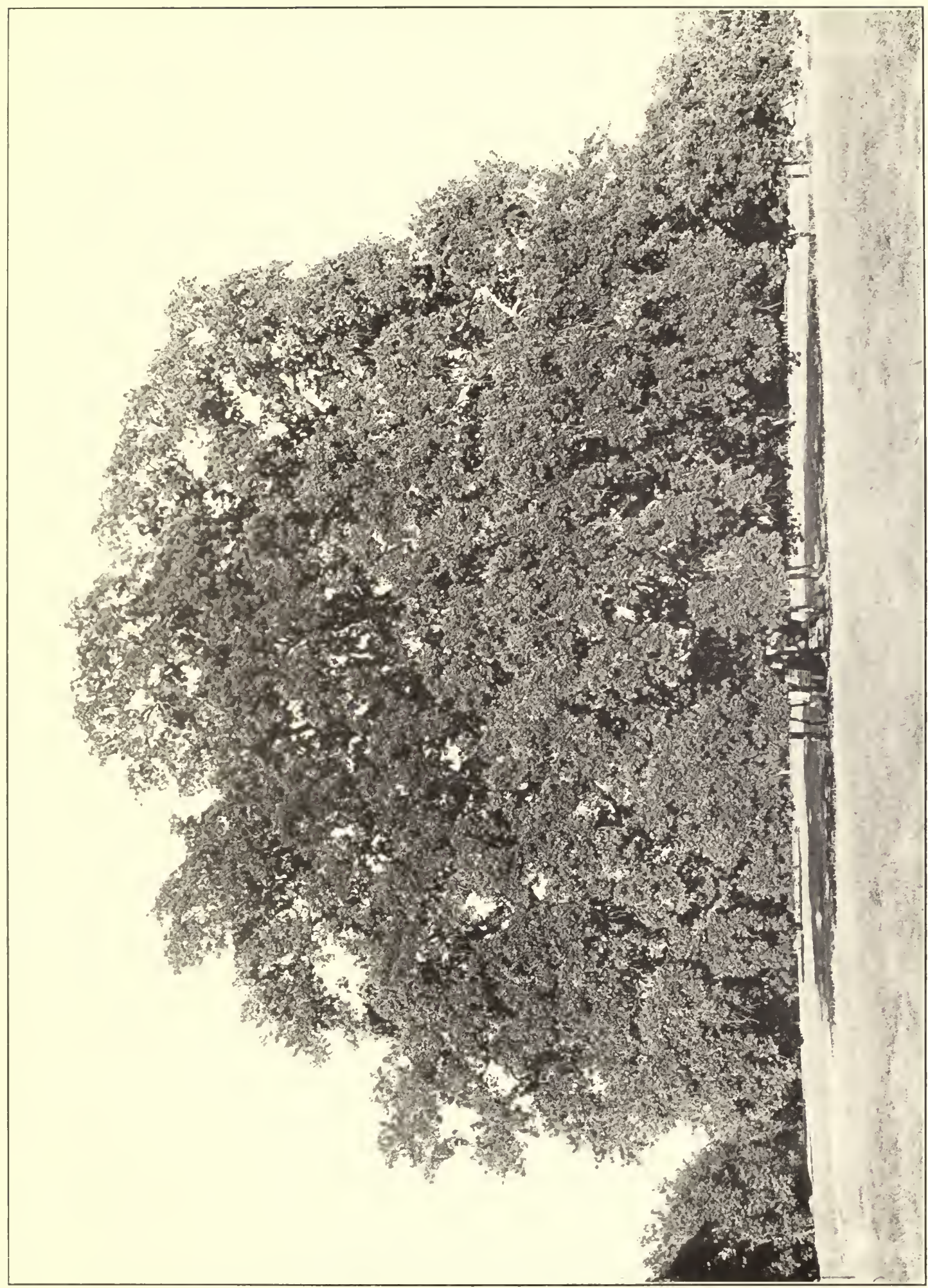

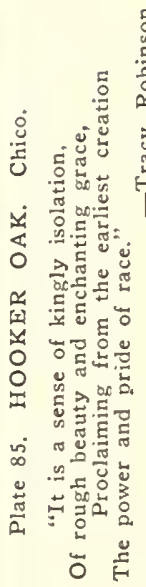




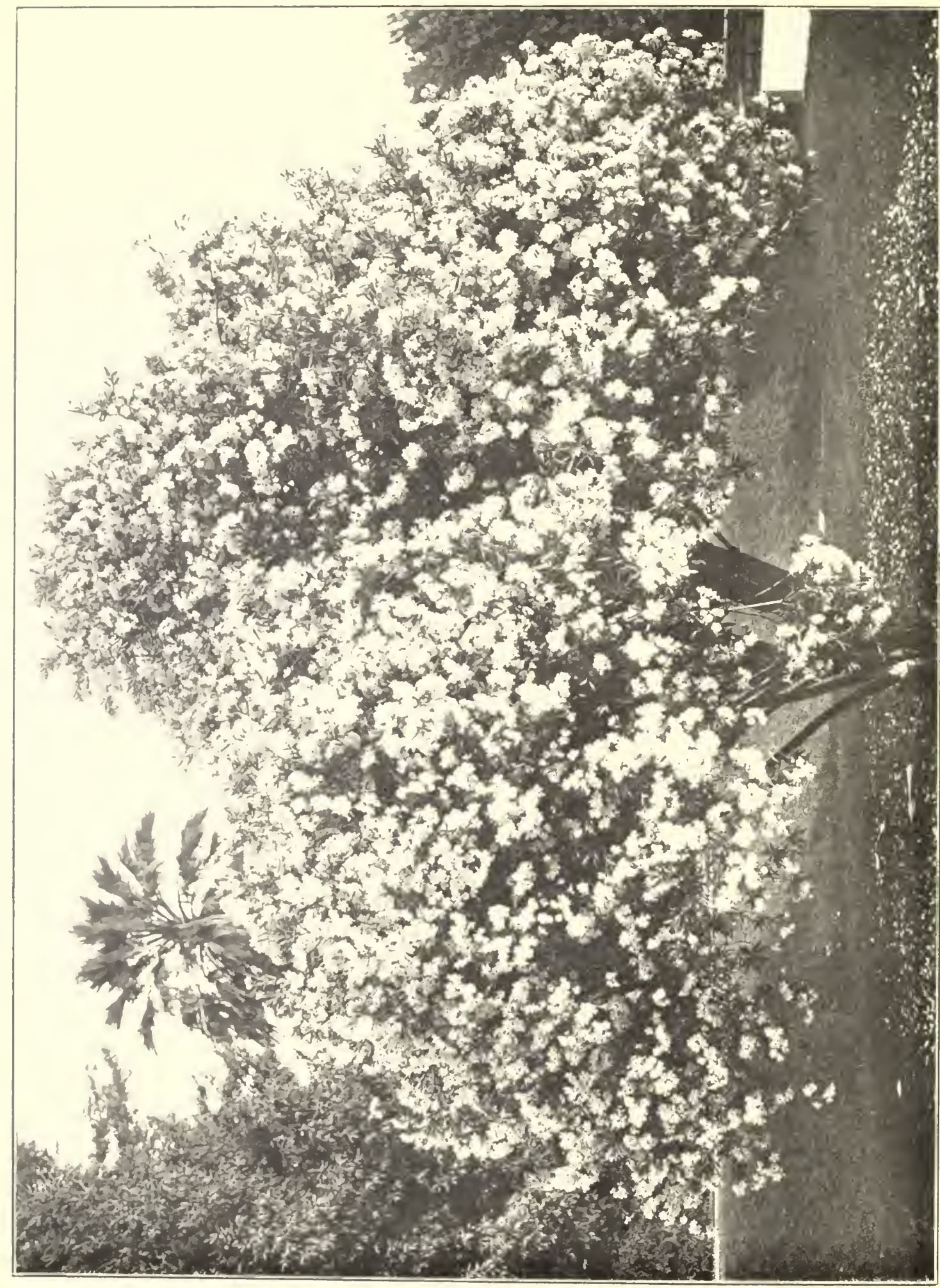


This tree is very common in southern California, where it is extensively planted on the streets of some of the principal cities. The stately form, fern-like foliage and orange-red flowers are the reasons for its choice. In old age, however, it loses much of its charm, because of breakage due to the brittleness of the wood. Moreover, it is considerable of a nuisance because of the constant dropping of the leaves, and the capacity of the roots for entering water pipes. These faults make the silk oak poorly adapted for a street tree. On private estates, however, where it can be cared for, it is worth planting. It does not do well in sections of the state where frosts are severe.

\section{STERCULIAS}

The Sterculias are natives of the warmer regions of the world, the two species most commonly planted in southern California coming from Australia. The foliage somewhat resembles that of the camphor, but the growth of the trunk is entirely different. It swells at the butt giving the trees a pyramidal shape.

The flame tree (Sterculia acerifolia) takes its name from the scarlet flowers which are produced in showy clusters. It reaches a height of sixty feet and has a sturdy habit, with deeply lobed leaves.

The Victorian bottle tree (Sterculia diversifolia) has a peculiar pyramidal trunk growth, and bright, glossy leaves of many different shapes. The flowers are not striking as on the flame tree, and give rise to heavy seed-pods at the tips of the branches which tend to mar the symmetry of the tree by pulling the branches out of position.

\section{SYCAMORES}

The sycamores belong to the genus Platanus, which is the classical name of the plane tree. They embrace six or seven species found in North America, Mexico, Central America and Southwestern Asia. They are splendid trees of rapid growth with symmetrical, broad spreading habits. The leaves are large and are rather like those of the maple in appearance. Their dark green color makes an effective contrast to the gray bark which peels off in patches giving the tree a motley appearance which has caused it to be called the "Clothes Tree." The fruit is ball-shaped and is pendent. Its resemblance to 
buttons has given rise to another common term for the tree, that of "Buttonwool."

\section{AMERICAN SYCAMORE}

In a contest inaugurated by the American Genetic Association of Washington, I). C., for the location of the largest nonnut-bearing hardwood in the Linited States, it was found that an American sycamore (Platanus occidentalis) was the largest tree submitted. A tree near Worthington, Indiana, was found to be 150 feet high with a spread of 100 feet and a trunk circumference of over forty-five feet at one foot above the ground.

There are a number of historic sycamores in Massachusetts, notably those at Charlemont and Deerfield. It was under the sy'camore at Charlemont that the first pioneer settler of the township slept when he went there in $17+1$. He afterwards was killed by the Indians near this tree and it still stands as a monument to his memory. The Deerfield sycanore, which is now 100 feet in height, stands within what was once the enclosure of a fort built in 1689 . Near it stands the Stebbins house, where, in 1703, "seven men, besides women and children, held two hundred soldiers and one hundred and forty Indians at bay (under a French officer of the line) for three hours." (From James Raymond Simmons" "The Historic Trees of Massachusetts." )

The American sycamore grow's naturally along streams and lakes on rich soil. It is confined to the eastern and southern part of the United States. A close relative is a western species (Platanus racemosa), a picturesque tree of irregular growth that frequents the stream courses of the interior valleys and coast ranges.

The native sycamores are planted for shade and ornamental purposes but it has been found that they are inferior to the London plane in symmetry and are more subject to fungous diseases which disfigure the trees.

\section{LONDON PLANE}

The London plane (Platanus acerifolia) has for years been known and sold as the Oriental plane (Platanus orientalis) and is still so listed in many nursery catalogs. According to Dr. Augustine Henry the tree is the result of a natural cross between the American sycamore and Oriental plane which grew in Kew Gardens, London, and which still attracts the attention of 


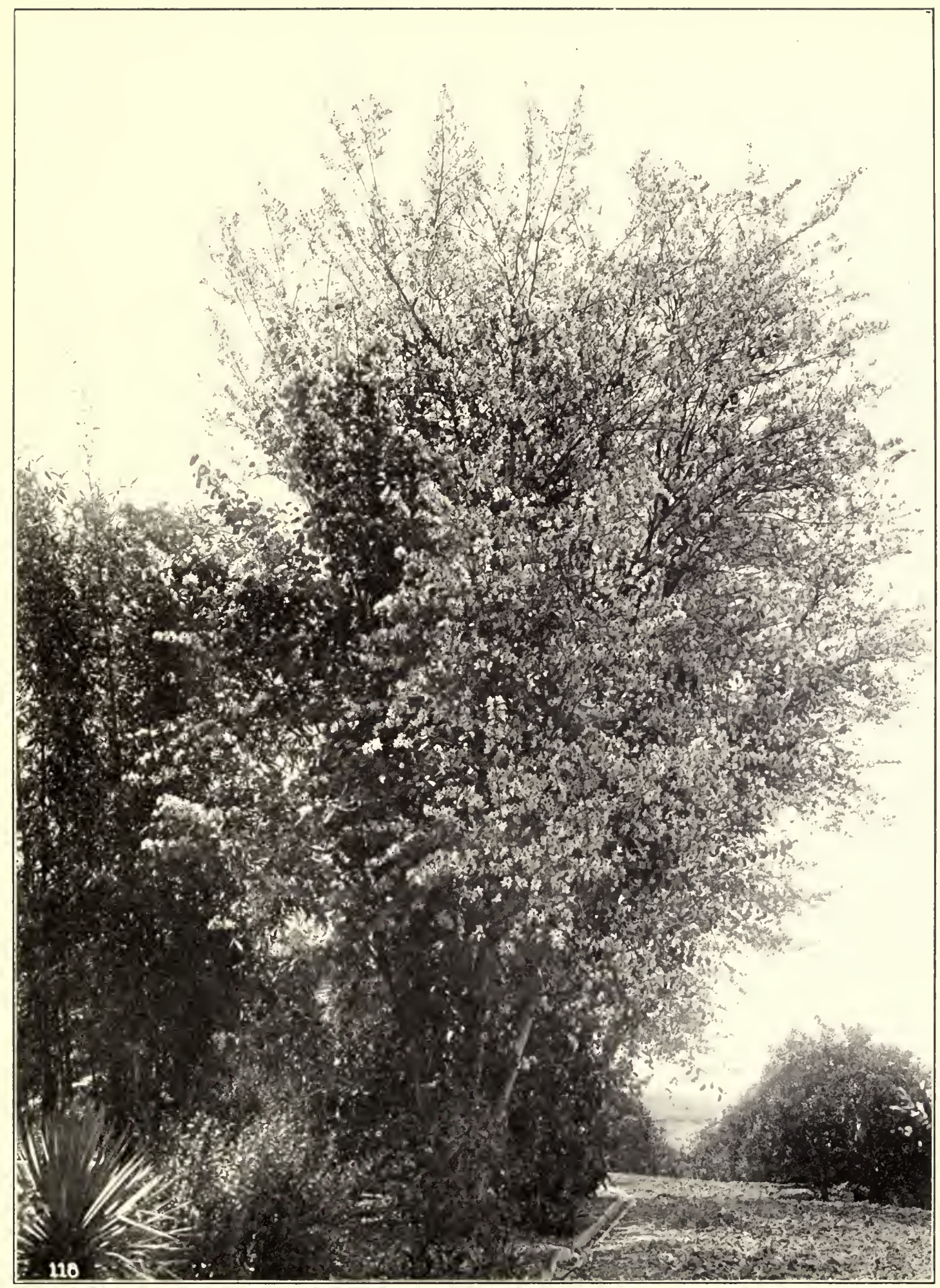

Plate 87. ORCHID TREE. Riverside.

A rare tree from the tropics which gives splendid ornamental effects in gardens in southern California. 


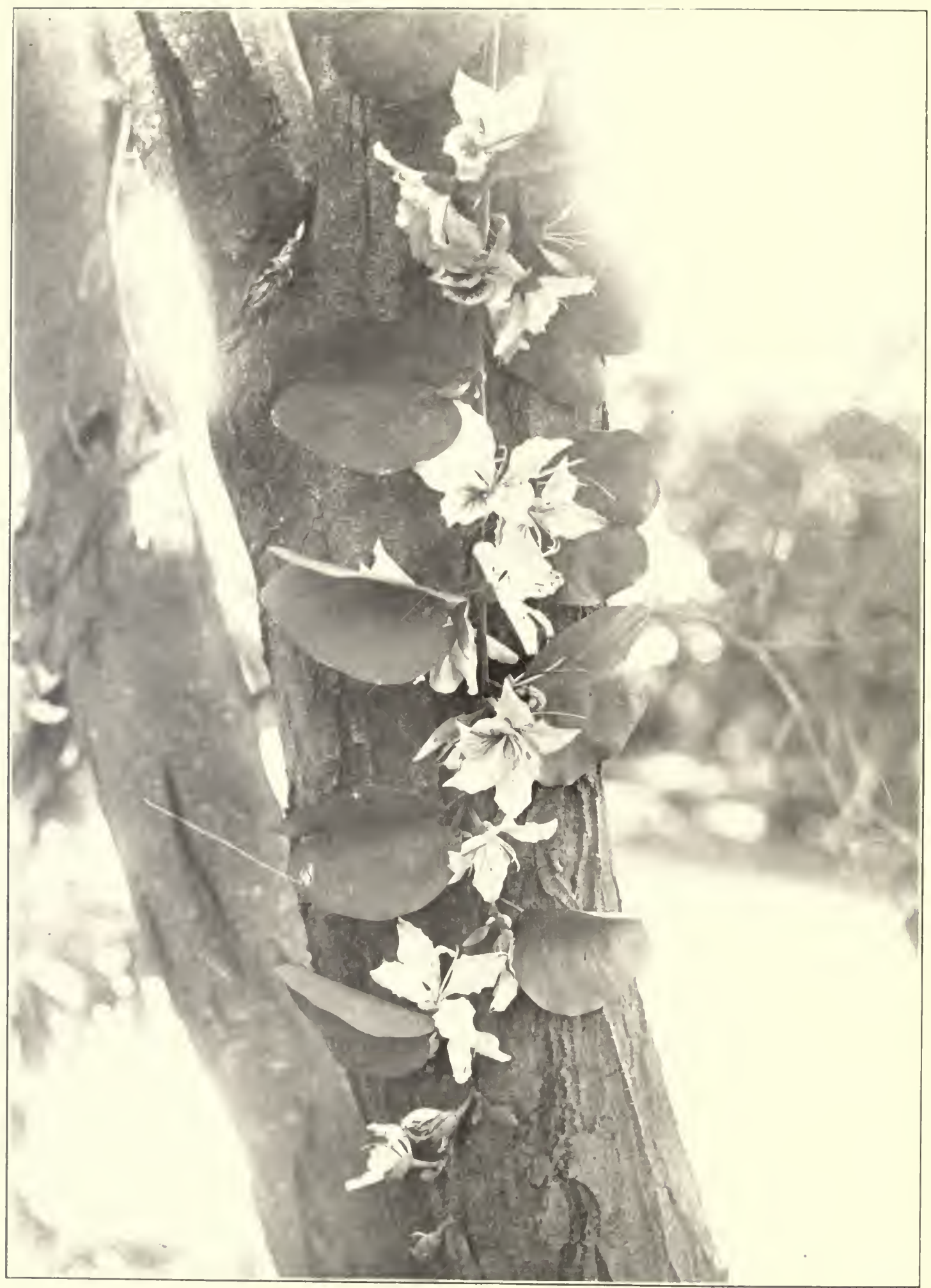

Plate 88. ORCHID TREE BLOSSOMS. Riverside. The orchidl-like flowers are deep laventer at a distance, but closer examination reveals tones of mauve and purple
with a touch of white. 


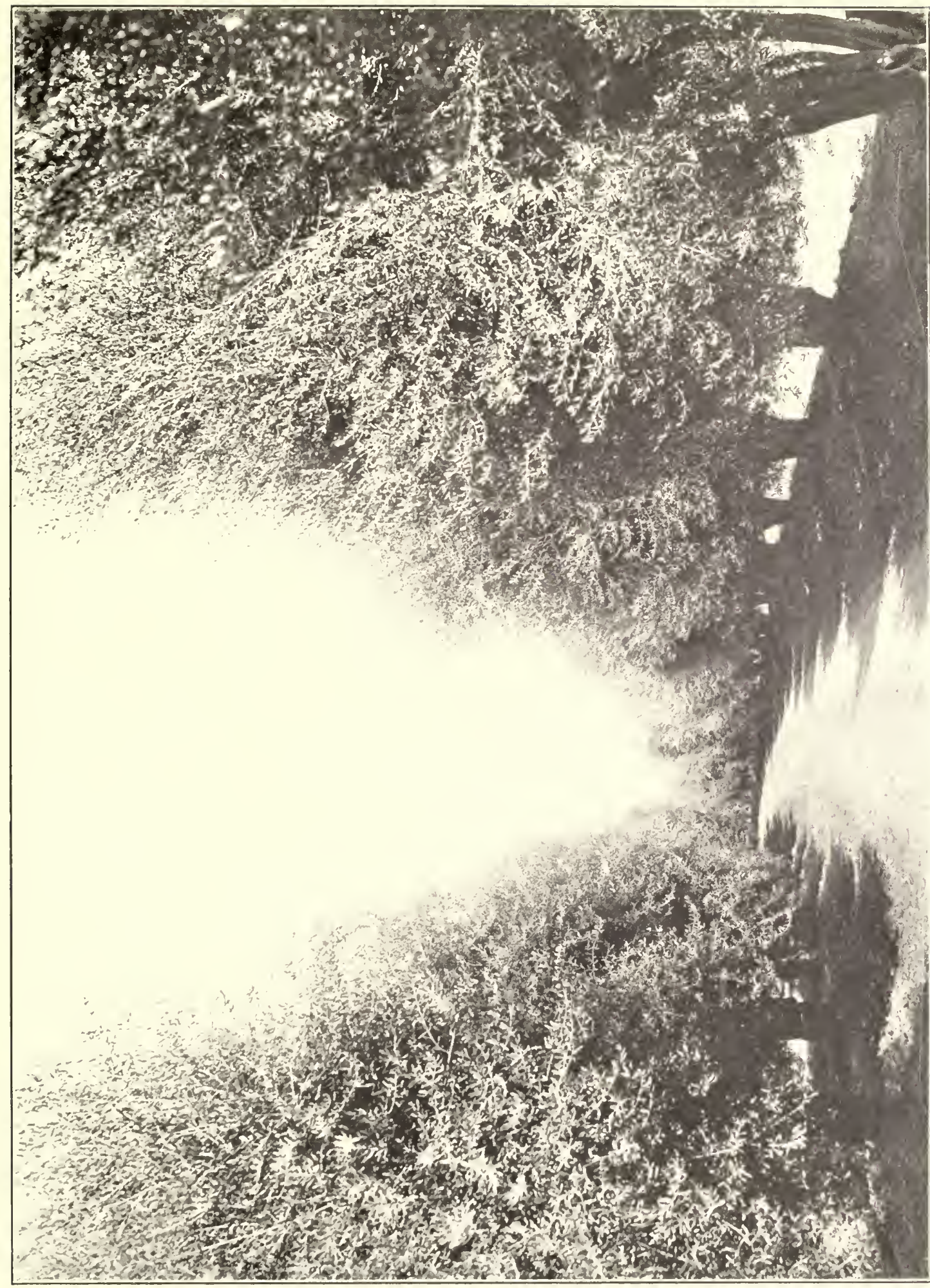




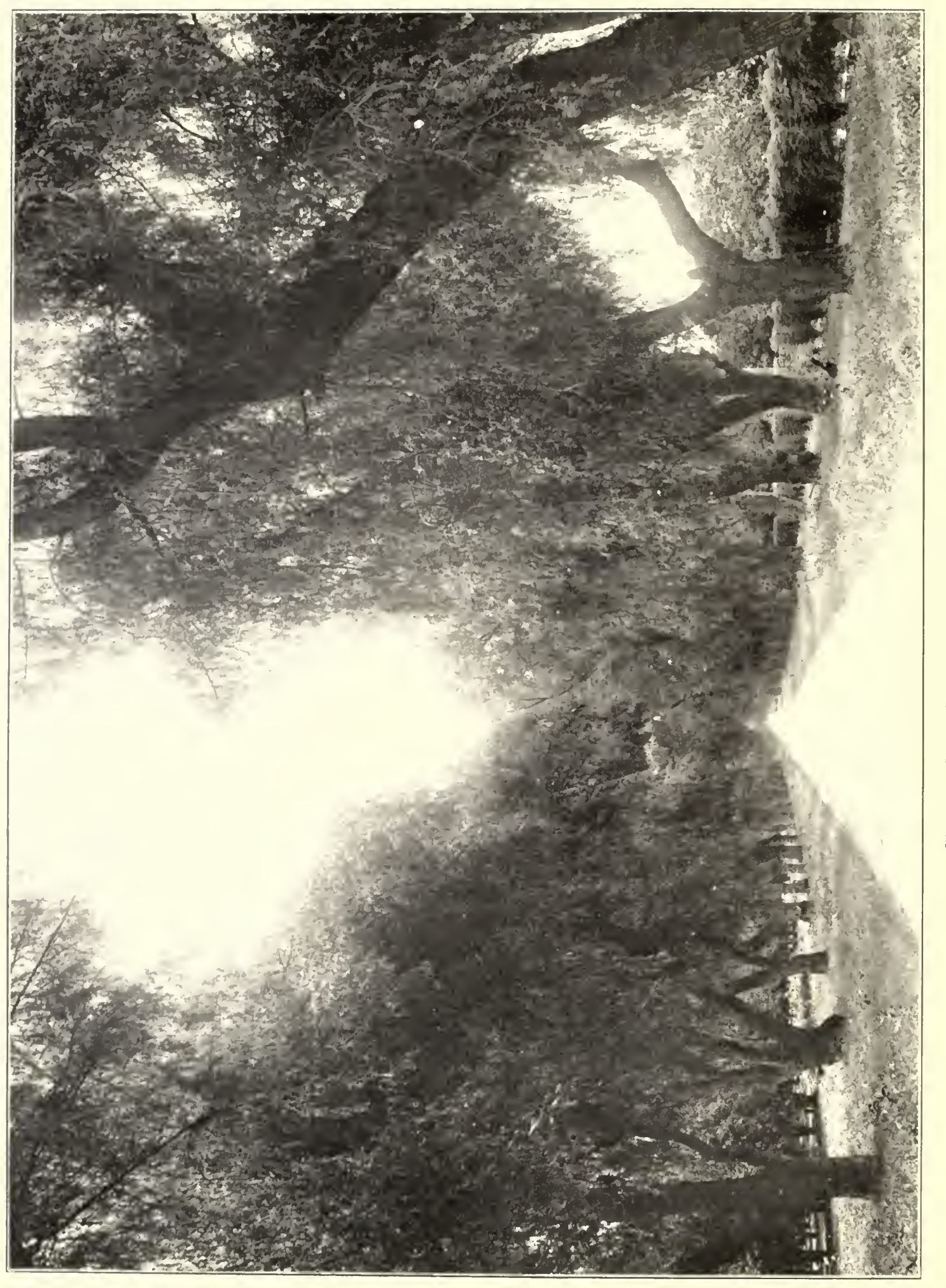


visitors by its size and beauty. The vigor and rapidity of growth of the London plane is due to this hybrid origin and these features have made this species one of the most highly recommended for street and highway planting.

The plane is a native of Greece, Cyprus, Rhodes and Asia Minor. It has always been highly regarded. The Greeks planted it in groves, under whose heavy shade their philosophers were wont to meditate. Tradition relates that when Xerxes invaded Greece, a plane so delighted him that he encircled it with a collar of gold, stamped a figure of it on a gold medal which he continually wore, and tarried so long beneath it as to ruin his chances of success. Pliny also admired this tree and tells us that no tree so well defends us from the heat of the sun in summer, nor that admits it more kindly in winter. The plane was held in veneration by the Egyptians and worshipped with fruit offerings and jars of water from which travelers might partake.

Near Constantinople there is a plane 100 feet high, 165 feet in circumference and 130 feet in the spread of its branches, which is 2000 years old or more. On the Greek island of Cos is a giant tree which has become so old and ponderous that it is necessary to support its branches with marble columns.

In his Sylva, Evelyn writes of "the incomparable and shady Platanus, that so beautiful and precious tree which we read the Romans brought out of the Levant, and cultivated it with so much industry and cost for its stately and proud head only; that they would irrigate them with wine instead of water; and so prized the very shadow of it, that when afterwards they transplanted them into France, they exacted a tribute of any of the natives who should presume to put his head under it."

The plane does remarkably well on London streets, where it was planted in 1789. Its distinctiveness has given it an important place in modern English art, and it is often to be seen in paintings and drawings. The streets of Washington and Philadelphia have many beautiful specimens, and the planes that were planted in Sacramento a few years ago are so vigorous and attractive that they have been widely planted in all parts of the city. The tree is well adapted for street and highway planting because of the ease with which it is transplanted, its resistance to insect pests, symmetry and rapid growth. It is disposed to grow rather large but stands severe pruning well and can be made to conform to the width of any street without injury. 


\section{TAMARISK}

The tamarisks (Tamarix) are shrubs or small trees with small scalelike deciduous leaves greatly resembling those of cypress, and spikes of small pink or white blossoms which completely cover the trees in spring. They grow naturally on the sea shore or in sandy places, from Japan and China to Madeira and the Canary Islands, and from Senegambia to Siberia. They thrive in the very spray of salt water.

The name tamarisk either came from the river Tamaris in the Pyrenees, on whose banks it grows, or from the Hebrew tamarik, cleansing, from its use either for purifying the blood or for making brooms. A decoction of the young twigs is said to be used by the Tartars for rheumatism and for bruises. A Syrian species, when stung by an insect, exudes a mucilaginous sugar which the Arabs term "manna" and which they use with their unleavened bread.

No shrub is better adapted to the planting of waste spots where soil and moisture conditions are adverse. It thrives under almost any condition, and will grow readily from cuttings, like the willow. It makes a good windbreak due to its dense foliage and does not sap, the ground since the roots go straight down instead of spreading in a lateral direction. It reaches a height of ten to twelve feet, but can be readily trimmed to form hedges if desired.

\section{TULIP}

The tulip (Liriodendron tulipifera), commonly called yellow poplar, was one of the earliest of the hardwoods that flourished in the cretaceous age. In that remote time, the genus to which it belongs, and which is now represented by only two species, one in Central China and the other in the eastern part of the United States, flourished in Greenland together with bald cypress, sycamore, redwood and other trees which were forced to the south during the Ice Age. The ice pushed from the north down to middle United States, burying everything. Many species of trees perished, but the tulip managed to survive and worked its way as far north as Canada when the ice sheet finally melted away. Some of its former companions, notably the redwood and big tree of California, never succeeded in extending their range to the north after being pushed to their present location. 


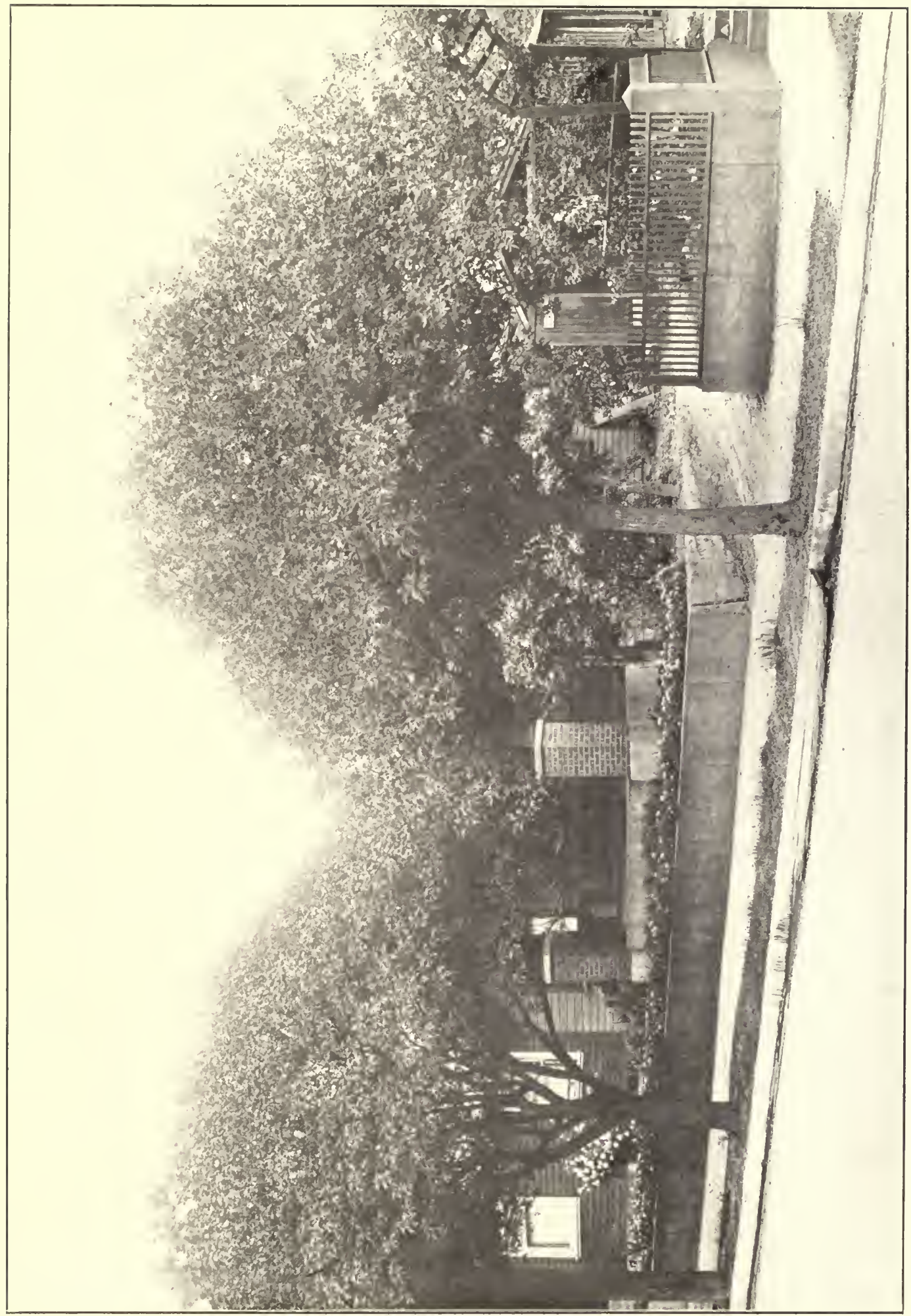

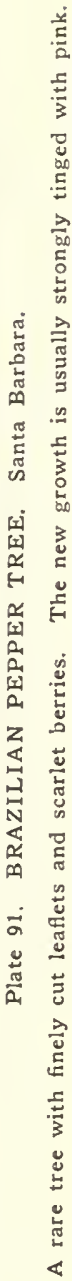




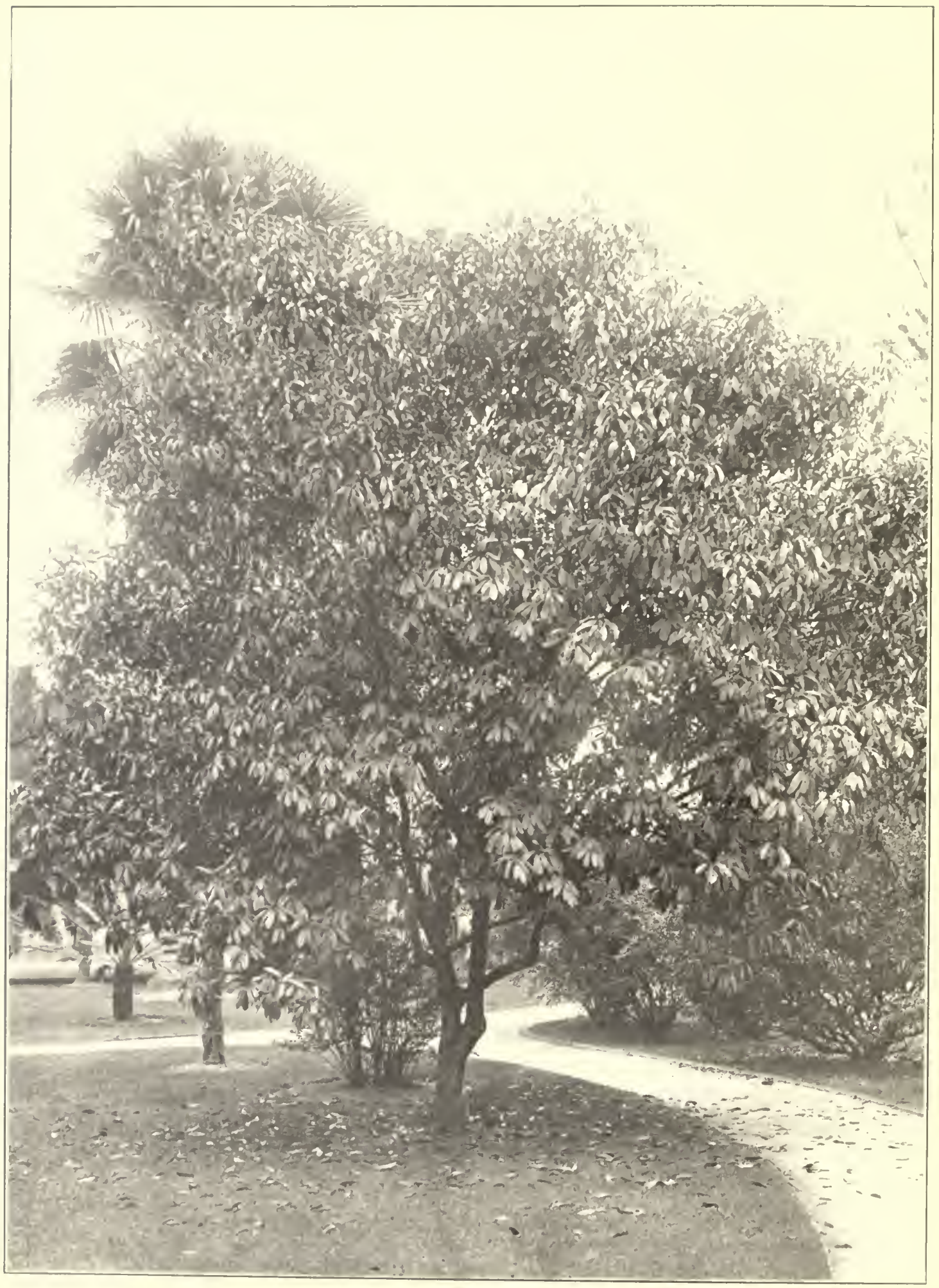

Plate 92. PHOTINIA. Pasadena.

A small Chinese tree that belongs to the same genus as the California redberry, which is the glory of our hillsides in fall and winter. 
The tulip reaches its best development in the Southern Appalachians where it reaches a height of 120 feet with a tall, straight unbranched trunk. It has a pyramidal habit, something like that of a conifer, and an open appearance due to its comparatively few branches. The bark is dark, mottled with dark spots and fissured with fine lines.

The tulip is linked with the history of the Southern States. In 1779 , Indians assembled near Chattanooga for an attack on the Carolina frontier. Isaac Shelby, a pioneer leader, had canoes hewed out of trunks of the tulip, and tcok 750 men down the Holston River to attack them. A few years later a force of Scuth Carolina revolutionists clefeated one thousand tories led by Major Ferguson. Because of the crimes conmitted by the captured rovalists, ten were condemned by court martial and hanged to a tulip on Kings Mountain.

On the campus of St. Johns College, Annapolis, stands the famous Liberty Tulip under which the early colonists discussed their rights. In 1825, General Lafayette, a champion of their struggle for liberty, was entertained under this tree. Although its trunk is a mere shell, yet it flourishes and bears thousands of blossoms every year.

The lumberman's term for the tulip is yellow poplar. It is probable that this name was given it because its leaves, like those of poplars, flutter in the breeze, and because the color of the heartwood is somewhat yellow. The wood is highly prized and has many uses such as for veneer, furniture, tobacco hogsheads and candy boxes.

Is a shade tree, the tulip retains its beauty and symmetry from youth to old age, and has added attractiveness because of its striking leaves and flowers. Like other members of the magnolia fanily, to which it belongs, the tulip has large showy flowers. They are tulip-shaped and yellowishgreen in color with darker yellow and deep orange on the tip of the petals. Stout stems bear them erect above the pale green foliage of the tree.

The leaves of the tulip, which are deciduous, are unique in shape. They are angular with four points, and have peculiar chopped off ends, which gives them a fiddle-shaped appearance. The fluttering of the leaves in the wind is due to the triangular leaf stems which vibrate as do the flat ones of the poplar. The fruit is a cone, several inches long, composed of thin, narrow 
scales attached to a common axis, each scale bearing a seed. The seed ripens in ()ctoher and blows away leaving the empty spikes erect on the tree.

Although a handsome shate tree, the tulip is rather hard to grow successfully: It has the fleshy roots of the magnolias which makes it hard to transplant. In transplanting care should be takien not to bruise the roots. or allow them to dry out. The trees should be planted in the early spring in deep, rich soil. Careful attention is needecl for several years, but after the tree becomes established it grows rapidly and is little troubled with insects. Because of the size it attains at maturity; it should not be used on narrow streets.

\section{UMBRELLA TREE}

The umbrella tree (Melia azedarach var umbraculiformis) is widely planted in California because of its rapid growth and its quickness in giving shade. Its common name is giren because of the umbrella-like shape of the tree. It is also called the China tree due to its Asiatic origin.

The umbrella tree is popular hecause of its delicate bright green foliage, which it carries until late in the season, and its long sprays of fragrant lilaccolored blossoms. When well grown it forms handsome specimens, but in many cases it is not properly pruned with the result that too many branches are formed and breakage from the wind results. This tree also has objectionable features clue to the excessive litter of leaves and its slippery fruits which are apt to cause accidents The umbrella tree has its place, but its faults do not recommend it for widespread planting as a street or highway tree in view of the many more desirable species that can be used.

\section{WALNUTS}

The original home of the walnut was probably in the north of Persia. The Greeks thought highly of the tree and accounted for its excellence by a story that Bacchus loved Carya, a king's daughter. Her sisters were jealous and interfered, and Bacchus, greatly enraged, changed them into stones, and Carya into a walnut.

Introduced into Italy before the Christian era the walnut was named Juglans, a corruption of Jovis glans, the nut of Jove, food nut for the gods. It was looked upon as sacred to Diana, whose festivals were held beneath its 


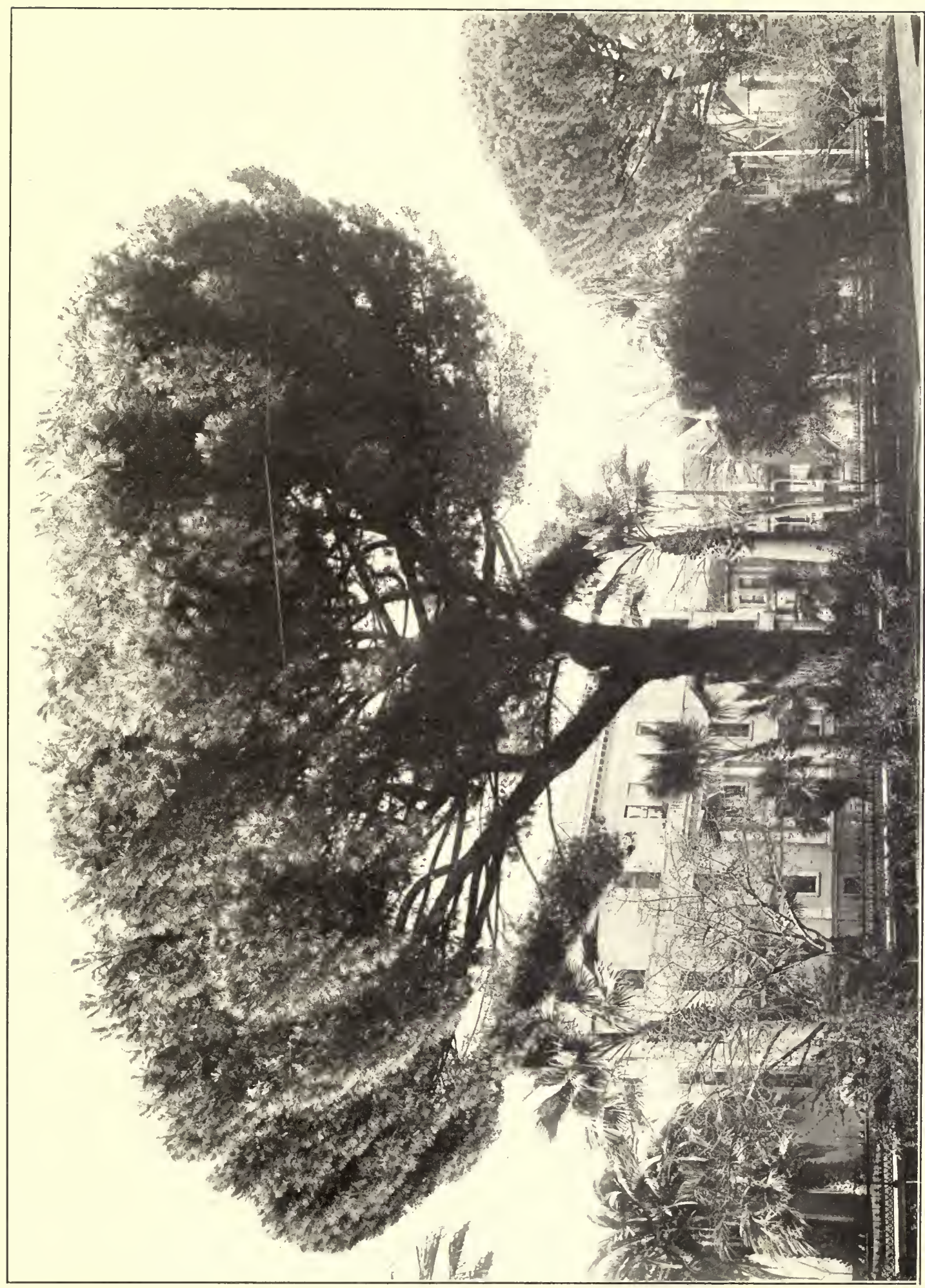

을 


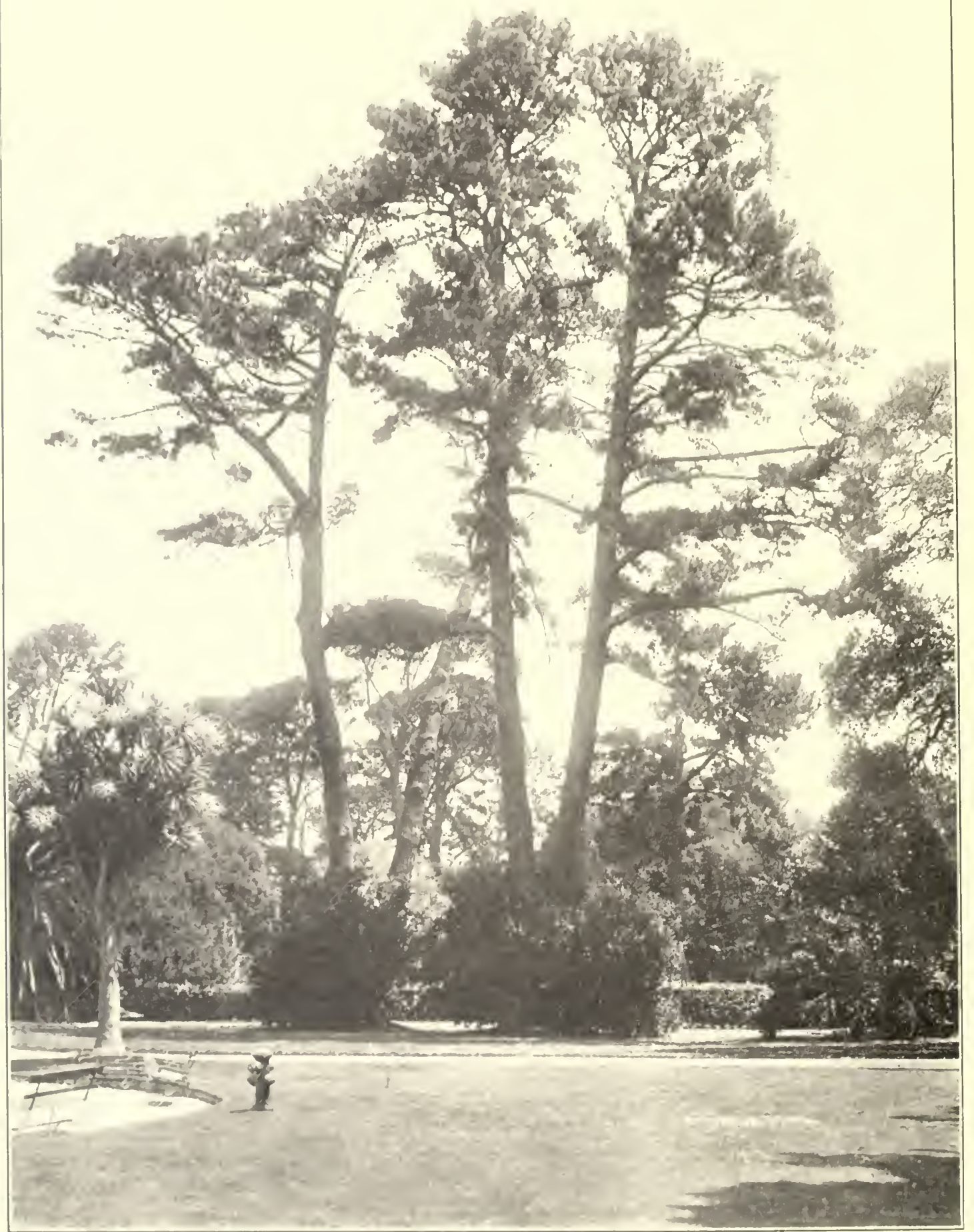

Plate 94. PINES OF MONTEREY. Del Monte.

Anchored in firm-se: rock, ye ride the blast.

And from the promontory's utmost verge

Make signal o'er the waters." 
shade. The ancients believed that walnuts were marked by nature to cure diseases of the brain or help in head troubles of any sort. This is due to the resemblance of the nut to the head. The hard shell is like the skull, and the thin, brown skin and lobed white flesh resemble the convolutions of the brain.

The herbalists of old believed that "The leaves with boar's grease stayeth the hair from falling and maketh it fair." Early disciples of Izaak Walton made a decoction of the leaves to water the ground to make worms come to the surface.

The value of walnut for furniture was recognized in King Solomon's time when this wood was brought from the Indies. The Venetians later carved walnut into elaborate cabinets. During the reign of William and Mary there began what has been termed the "age of walnut" when these monarchs brought to England walnut furniture in the Dutch and Flemish styles.

American walnut, or black walnut as it is often called, was closely associated with early colonial history. In 1633 Governor Winslow used a walnut table in presiding over his councils in Pilgrim Hall at Plymouth.

At Maplewood, New Jersey, stands a huge walnut which is said to have been planted in 1743 in front of the Timothy Ball house. When visiting his cousins, the Balls, General Washington hitched his horse to an iron ring which was attached to this tree.

So well known is the walnut in the United States that it has been proposed that it be adopted as our national tree. It grows naturally in the region occupied by four-fifths of the people of this country and has been planted and grown successfully in every state in the Union. One writer says "England has her oaks, Canada her maple, Italy her olives, Germany her linden, Japan her cryptomeria, why not America her walnut?"

The American walnut has many good points which entitle it for consideration as the national tree It makes a beautiful decorative and shade tree with its wide spreading habit and long, compound leaves. The wood is valuable for many purposes, and during the war was much used for gunstocks and airplane propellers. The nuts are much prized as food: The California species is used as a stock graft for English walnut since it is thriftier than that species and its roots are better adapted to our soils. 
There are ten species of walnuts found in the world, the most important commercially being the Eastern black walnut, which is found from Massachusetts and Minnesota south to Texas and Florida. It reaches a maximum height of 150 feet with a trunk diameter of four to six fect. Under best conditions it lives to be 250 years old.

\section{CALIFORNIA BLACK WALNUT}

California black walnut (Juglans californica) is a native tree which is found along streams in southern and central California. In southern California it usually branches near the ground and has a shrub-like habit. A tree is reported in Ojai Valley, Ventura County, which has a crown diameter of ninety-two feet and a trunk circumference at the base of fourteen feet five inches. Even this large tree has a shrub-like habit since all of the lower limbs creep on the ground.

On the banks of the lower Sacramento River this tree forms tall, roundheaded trees forty to sixty feet high, with a diameter of one or two feet. This tree is now known as Juglans hindsii and is regarded as specifically different from the southern California tree. Some of the best specimens are found growing along Walnut Creek, Contra Costa County. Both these localities are near ancient Indian village sites, and since there is a wide gap in the distribution of the walnut between these localities and those in southern California, Jepson thinks that the nuts were brought north and planted either by the Indians or the first European settlers.

The California black walnut makes an excellent roadside tree since it grows rapidly into a symmetrical trce which affords an abundance of shade. The handsome, pinnate, glossy leaves add much to its attractive appearance. The nuts are ripe in October, but the kernel, although very palatable, is difficult of extraction because of the thickness of the shell. The tree is best suited for wide roads where its spreading habit and sturdy growth are most effective. It is rather difficult to transplant, and needs a deep, rich soil for its best development. Under favorable conditions it reaches a height of seventy-five feet. 


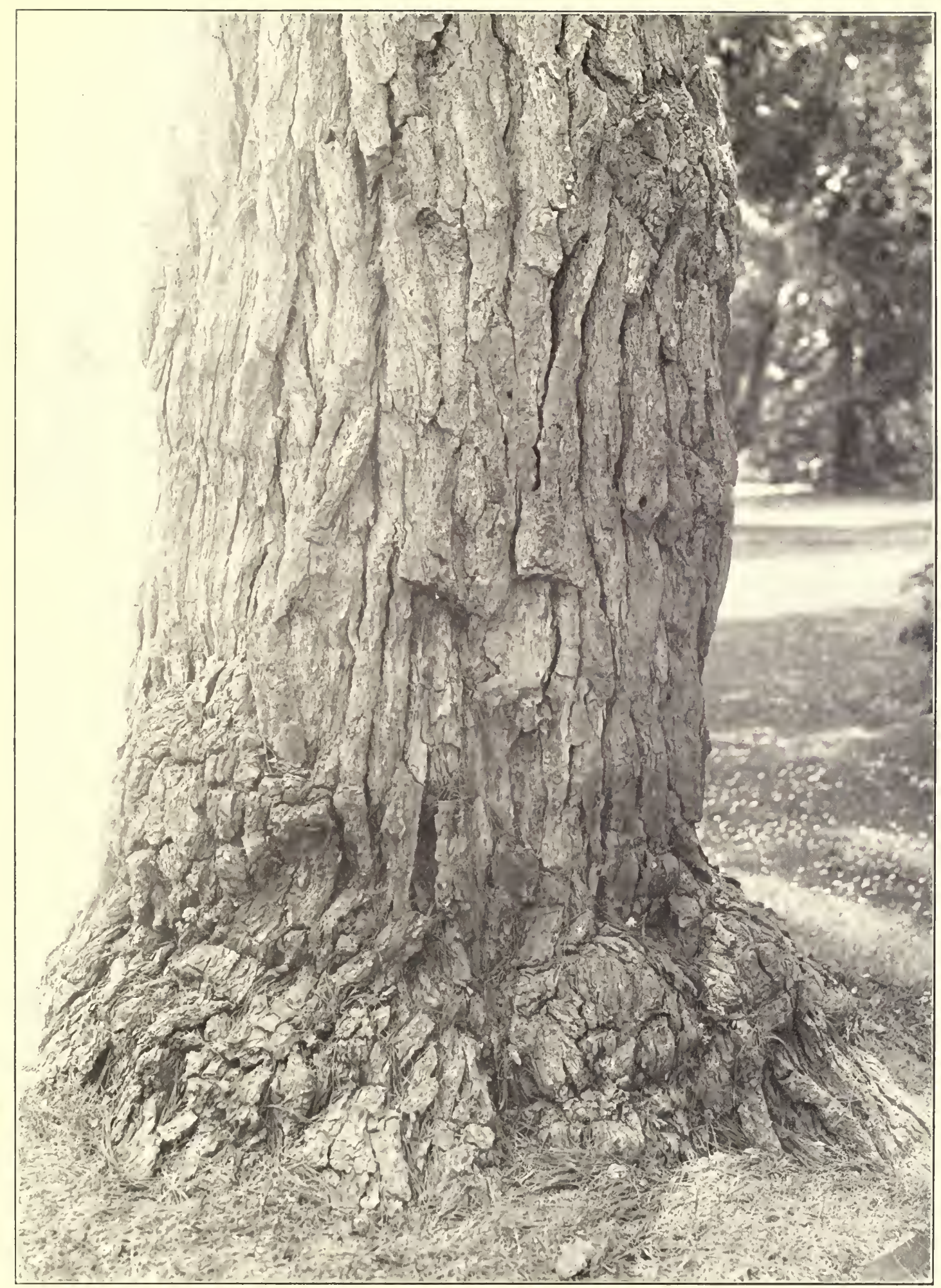

Plate 95. MONTEREY PINE TRUNK. Del Monte.

A handsome native pine of California that has extremely rapid growth. 


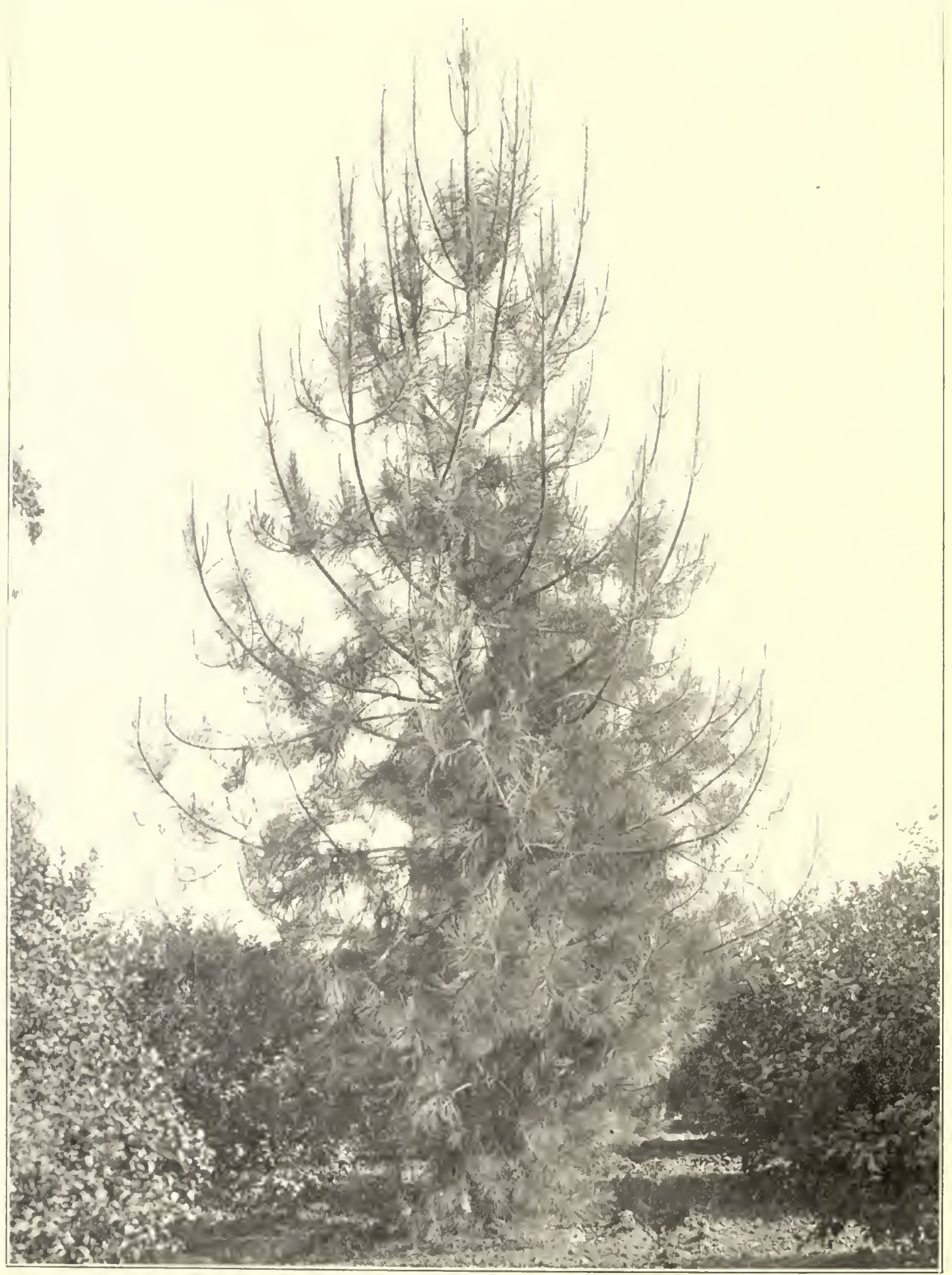

Plate 96. TORREY PINE. Hollywood.

Under cultivation this pine makes a rapid growth. The heavy tufts of needles on the ends of the branchlets give it an attractive appearance. 


\section{WILLOWS}

Sir Joseph Hooker called Salix a "troublesome genus" since it embraces so many kinds of willows and they fertilize so much among each other that the botanist is hard put to distinguish between them. About 170 species have been recognized, and there are an endless number of varieties, of wide range in all parts of the world. The name willow, from the early English word welig, refers to the flexibility of the young branches.

The willow is so meek and humble in its habits that it has been called the Cinderella of trees. It has long been considered the symbol of unrequited love and was spoken of by Fuller as "A sad tree, whereof such as have lost their love make their mourning garlands." Shakespeare portrays Dido, Queen of Carthage, when forsaken by Aeneas as standing with a willow in her hand to waft her love to come again to Carthage.

The association of the willow with grief probably had its origin at the time the Psalmist recorded that the Hebrews hung their harps upon the willows and wept by the rivers of Babylon. Even to those who have not been influenced by Biblical tradition the willow has been a symbol of sorrow. Torches made of willow were used by the ancients at funerals, and "to wear the willow" was an outward symbol of grief. The Druids are stated to have burned their human sacrifices in wicker cages.

Willows are rapid growers, but usually short lived. They are generally found along streams and spring up so abundantly that they quickly take possession of localities suited to them. The children of Israel were promised to be multiplied like "willows by the water courses." A few of the willows are large-sized trees, and grace proud estates with their beauty. Others are shrub-like and serve a humble capacity of clothing the waste places of the earth.

The willows belong to the lowest order of deciduous broad-leaved trees, and fossils show that they were of the earliest groups of plants that flourished when the earth was young. It is probable that they owe their survival to their tenacity of life since they never overlook an opportunity to gain a foothold. A small section of willow twig containing a bud, or a piece of a root, when covered by moist soil, takes root and rapidly develops into a shrub or tree. Willow stumps send up multitudes of shoots which are often a great nuisance 
to the agriculturist who secks to clear land for cultivation. The sprouting capacity of the willow; however, makes it useful for binding embankments which are subject to erosion.

The willows have high ornamental value, particularly along watercourses, where their fine, graceful foliage proluces an airy effect which heightens the transparency of the water. The close association of willow's with water was noticel by Cowper, who sail:

"The willows dip

Their pendent boughs, stooping as if to drink."

\section{WEEPING WILLOW}

The wecping willow (Salix babylonica) is a native of Asia and North Africa, but has been widely propagated elsewhere by means of cuttings. This tree shades the tomb of Xapoleon at Saint Helena where its light foliage flow's like the dishevelled hair and graceful drapery of a sculptured mourner. It is related that the soothsayers of Babylon foretold the death of Alexander the (ireat when the boughs of a weeping willow swept the crown from his head as he was crossing the Euphrates in a hoat.

The cham of the weeping willow is best revealed along lakes and watercourses wer which it hangs its long, pendulous branchlets of soft feathery green. It is a perfect contrast to the formal Lombardy poplar, the light airy sprays of which rise perpendicularly. It prefers rather humble scenes along a glassy pond or romantic foot bridge where its pendent branches stoop to the water's eclge.

The first weeping willow in this country is said to have been grown from a twig brought by a British officer in 1776 . He secured it from a tree on the estate of the poet Alexander Pope and on his arrival in this country gave it to John Curtis of Virginia who planted it on his place.

Salix fragilis pendula, a variety recently introduced from China, has made wonderfully rapid growth at Chico and promises to become as popular a weeping tree as the above species. 


\section{THE PALMS}

The term palm is derived from the Latin, palma, meaning the flat of the hand. From this sense the word was applied to the palm tree, because of the resemblance of its leaves to the outspread hand.

The palms embrace 150 genera and 1200 or more species of monocotyledons. They are found almost exclusively in the tropics where they form a striking part of the vegetation. They generally have a columnar trunk often buttressed at the base, crowned with a rosette of large leaves, although some species have branching habits and are only a few feet in height. The leaves are either palmate (fan-form), or pinnate (fern-form).

The Bible has many references to the palm tree, which is an emblem of constancy, fruitfulness, patience and victory. It is described as an upright, tall, flourishing and shadowy tree growing by sweet springs of water. The finest palms were about Jericho and along the banks of the Jordan.

It was probably under date palms that the children of Israel pitched their camp at Elim because there "were twelve fountains of water and three score and ten palm trees." (Num. 33:9.)

Date palms produce a great number of suckers, which form a kind of forest by their spreading. It was under palm trees of this kind that the prophetess Deborah dwelt between Ramah and Bethel. (Judg. 4:5.) It was probably to this multiplication of the palm tree that the prophet makes allusion when he says "The righteous shall flourish like the palm tree." (Ps. $92: 12$.) It is a fitting emblem of a just man because it is constantly green, flourishing and fruitful.

A branch or leaf of the palm was borne by the ancients as a symbol of victory and rejoicing. "A great multitude * * * stood, before the throne, and before the Lamb, clothed with white robes, and palms in their hands." (Rev. 7:9.) The poet Wordsworth refers to the ancient custom of using both palms and willows as symbols of rejoicing:

"The Hebrews thus, carrying in joyful state

Thick boughs of palm, and willow from the brook

Marched round the altar." 
From this symbolism the palm has come to be a token of success and is used in this sense hy Shakespeare. "So get the start of the majestic workd and hear the palm alone."

\section{CALIFORNIA FAN PALM}

The California fan palm. which is named in honor of George IVashington (II"ashingtonia filifera), is the stateliest of all our palms. It inhabits the interior dry region of southern California and often forms small groves along alkaline streams on the margins of the Colorado Desert. The palm groves in the canyons at Palm Springs in Riverside County are famous because of their picturesque appearance and ancient lineage.

In its native state the California fan palm reaches a height of seventyfive feet and a liameter of three feet. The fan-shaped leaves, which are from three to six feet kong, with forty to sixty folds, were formerly used by the Indians to thatch their huts. They also ate the soft bases of the young leaves besicles the fruit. which is borne in large clusters

This palm is extensively cultivated and does well in deep, well drained soil and where there is a plentiful supply of water during the growing season. It does not (to well in cold, exposed situations but in the interior portions of California as far north as Butte County, and on the south coast, it makes a vigorous growth. It is customary to remove the dead leaves each year, but the appearance of the older trees is more striking when they are allowed to remain.

There is great difficulty in restraining small boys from touching matches to these masses of dead leaves on the famous palm lined avenues near San Bernardino. Mlany of the fine palms have been badly injured in this way.

\section{CANARY ISLAND DATE PALM}

The Canary Island date palm (Phoenix canariensis) is an introduced species from the Canary Islands which is the most widely planted palm in California. The name Phoenix was given the date palm by Theophrastus, probably because it was first seen by the Greeks in Phoenicia.

It is valuable in landscape planting, but its ultimate great size should be kept in mind so that room will be allowed it for development. It should not he planted on narrow streets or parkings of average width, nor in yards too small to accommodate it at maturity. 


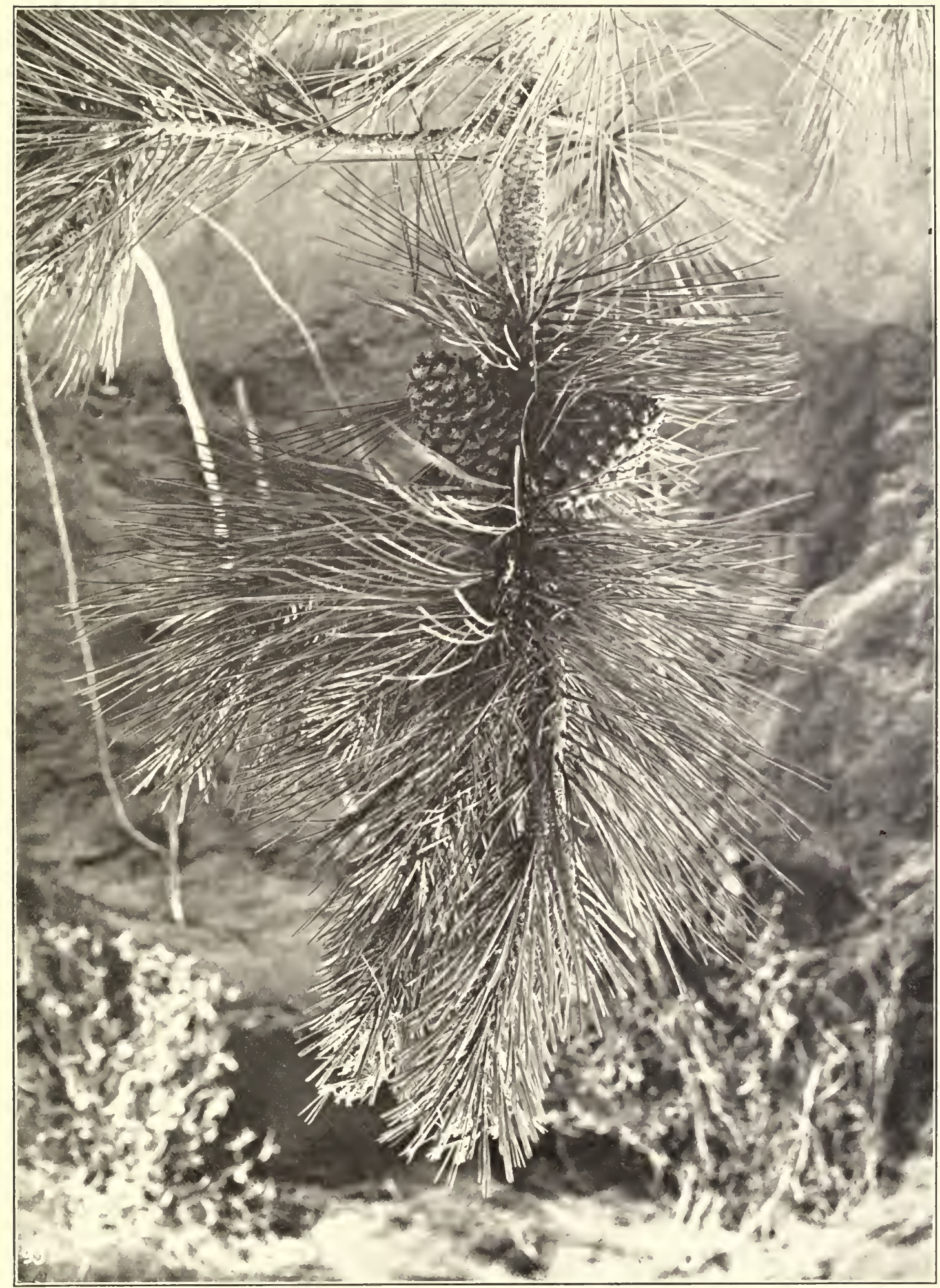

Plate 97. TORREY PINE CONES. San Diego. 


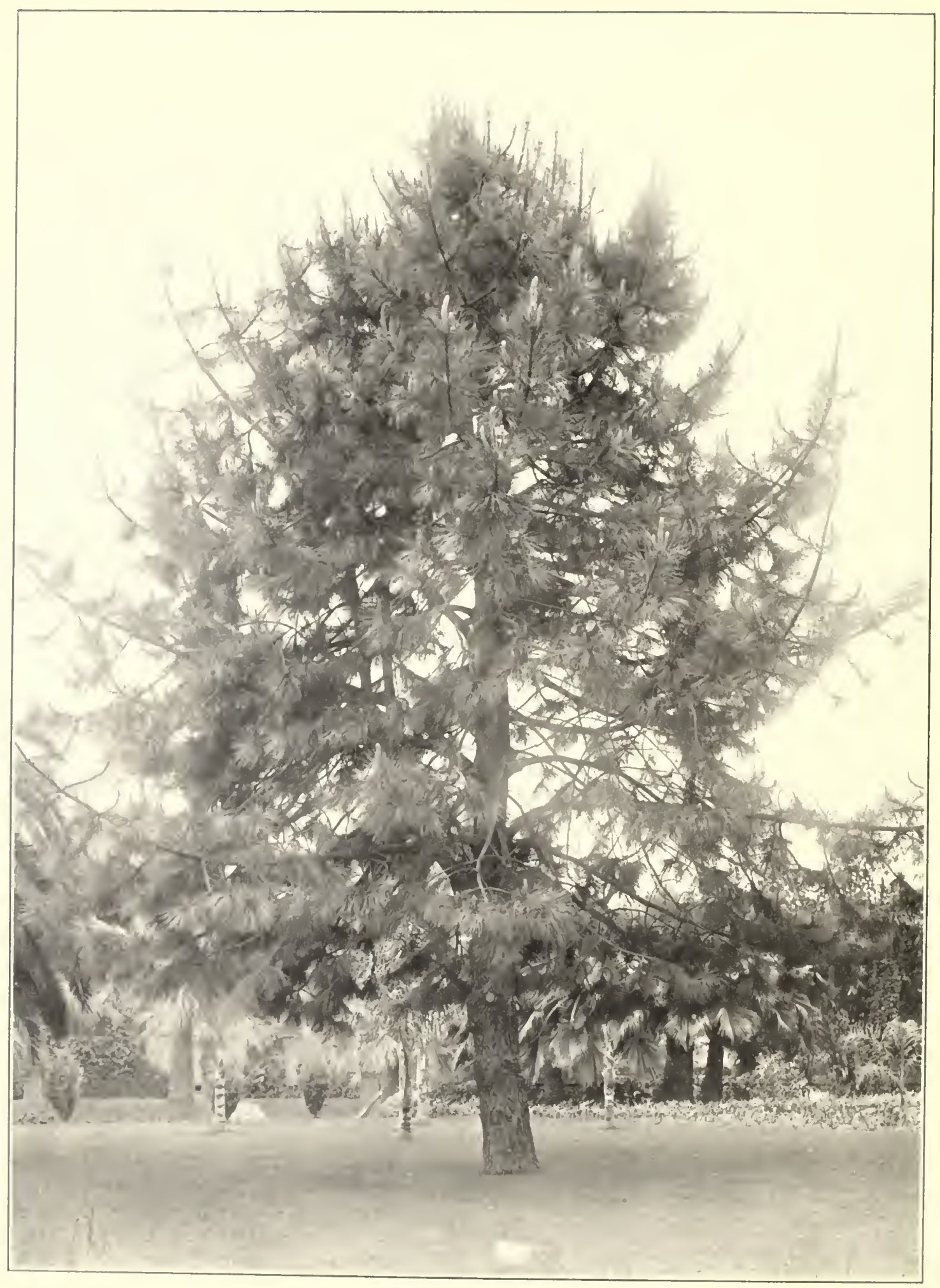

Plate 98. COULTER PINE. Pasadera. 
Like many of the palms, its early growth is exceedingly slow, but after a height of three or four feet is attained, development under favorable soil and weather conditions is rapid. A height of twenty-five feet and a spread of thirty feet are common at ages ranging from ten to twenty years. This palm has been known to withstand severe frosts, and has undoubtedly proved its hardiness in withstanding drought, hard winds and an appreciable amount of alkali. Very attractive landscape effects can be obtained by grouping the Canary Island palm with species of Cocos, Sabal and other palm varieties.

\section{COCOS PALMS}

The Cocos palms are a very large tropical and semitropical genus of pinnate-leaved palms, including the cocoanut. The generic term Cocos is a Portuguese word meaning monkey and has reference to the nut, which resembles a monkey's face. There is considerable variation in the habit and appearance of the different species. Some have dwarf growth with recurved leaves, and others are erect with long, nearly erect, plumy leaves. In the latter class is the Cocos plumosa from southern Brazil, which forms beautiful avenues in southern California from Santa Barbara south. They frequently attain a height of forty feet and give attractive ornamental effects because of their characteristic trunks and plumy crests of long feathery, swaying, darkgreen leaves. North of Santa Barbara this species frequently succumbs to frost, and should not be planted except in well sheltered places.

One of the best of the dwarf species is the Pindo palm (Cocos australis). This species can be successfully grown in most of our valley counties. Its handsome form with leaves strongly arched and recurved well qualifies it for lawn planting. The graceful leaves are of a sage green color, and are usually covered with a bloom. Unlike the Canary Island date palm it can readily confine itself to limited space, seldom exceeding twelve feet in height or width. A unique and striking characteristic is the spiral effect caused by the similar bending to one side while arching of all the leaves on the plant. The fruit is edible with a flavor somewhat like that of pineapple.

\section{GUADALUPE ISLAND PALM}

The Guadalupe Island palm (Erythea edulis) takes its generic name from Erythea, one of the Hesperides, Daughter of Evening. It is found in (115) 
the wild state only on Cuadalupe Island. off the coast of Lower California. Under cultivation it is one of the most handsome of the fan-leaved palms. The large leares are borne (nn long stalks, and retain their rich green color for many years. It hears shing, black-skinned nuts whon comparatively young. This palm reaches a height of about thirty fcet, and does well in all the valley and coast counties.

\section{BLUE PALM}

Blue palm (Glaucothea armata), formerly placed in the same genus with the Guadalupe Island species, has a silvery hlue hue and leaves armed with curving spines. It is very show! hut has a slow growth and is difficult to transplant. Linder favorahle conditions it reaches a height of forty feet. Some very fine specimens are found in the gardens of Santa Barhara. It is probable that it will do well in the interior valleys since it has proved hardy. in Texas

\section{DATE PALM}

The true tate palm (Phoenix dactylifera) is a native of North Africa which hears edithle dates which mature in some parts of the state. It has rather a stiff growth when young, hut at maturity it is hard to surpass for scenic effect. The trunk is more slender than the Canary Island palm and the leaves coarser. Specimens grow as high as roo feet, some of them grown from seed from commercial dates reaching a height of fifty feet in thirty years. An undesirable feature of this palm is its habit of sending out suckers from the base of the trunk.

\section{CAPE PALM}

The Cape palm (Phoenix reclinata), which is a native of South Africa, has strongly curved leaves which arch gracefully, usually hanging edgeways. It is well suited for avenue planting and for single specimens on lawns because of its slender trunk which reaches a height of only about thirty feet. It is liable to sucker for a time but if the shoots are cut off for a few years, they will cease to sprout out. This palm thrives best in warm localities on sheltered situations away from winds and frosts. 


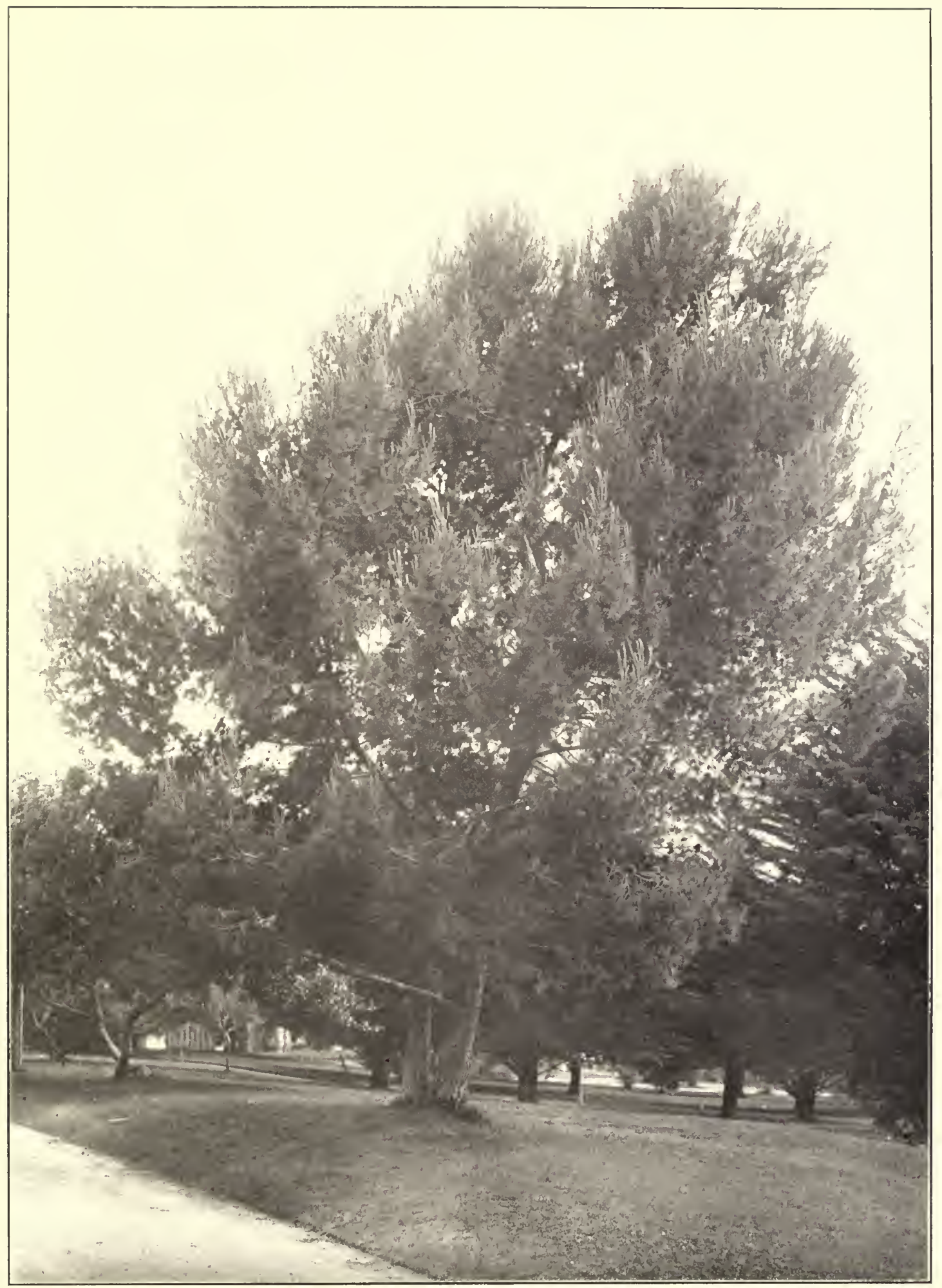

Plate 99. ALEPPO PINE. San Diego.

A pine from the Mediterranean region which thrives well in arid situations in California where it is particularly adaptable for seaside planting. 


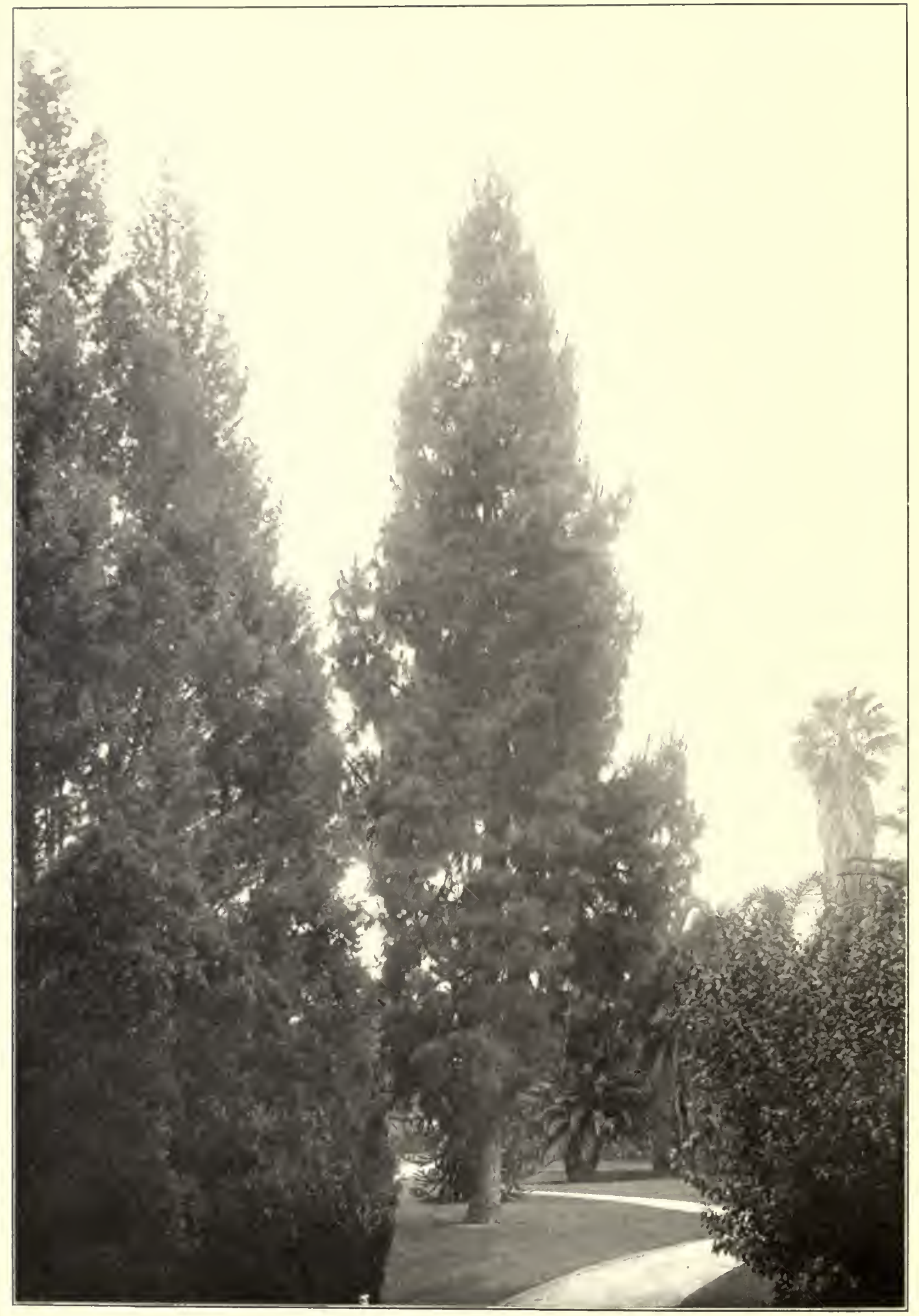

Plate 100. CANARY ISLAND PINE. Pasadena.

"As sunbeams stream through liberal space And nothing jostle or displace,

So waved the pine tree through our though And fanned the breeze it never brought." 


\section{WINE PALM}

The wine palm (Jubaea spectabilis), from Chile, took its generic name after Juba, king of Numidia. A large trunk of this palm yields about ninety gallons of sugary sap which is boiled by the Chileans to make palm honey, of which they are very fond. The fruits look like small cocoanuts and are called by the trade "monkey"s cocoanuts."

This palm has much the same habit as the date palm except that the foliage is closer. When old it forms a very thick, gray trunk which is free from leaves. Probably the finest specimen of this palm in the state is found in Los Angeles. "It is one of the hardiest palms," says Franceschi, "and can endure drought and many degrees of cold. If liberally treated, it makes a large tree in a few years."

\section{WINDMILL PALM}

The windmill palm (Trachycarpus excelsa) is an Asiatic fan palm which is know'n by the dense, black, hairy covering of its slender trunk. It reaches a height of about thirty feet and has a handsome crown of deeply cut fan-shaped leaves, giving it somewhat the appearance of a windmill. This palm endures more cold than any other palm and is easily transplanted and grown. It is well adapted for street planting since the trunks are very small and require little space.

\section{DRAGON TREE}

The dragon tree (Dracaena draco) takes its generic name from a word meaning female dragon. Its dried juice is supposed to resemble dragon's blood. This tree is often called the "Dracaena Palm," which is incorrect, since it is closely related to the lilies as shown by the flowers. The trees, which are tropical looking, have sword-shaped leaves and large panicles of white flowers.

The home of the dragon tree is the Canary Islands. A very famous tree stood in Teneriffe for many years. It was seventy-five feet tall and had a hollow trunk forty-eight feet in diameter in which a staircase was built. Specimens in California are from thirty to fifty feet in height. Their chief value is for the tropical effect which they give. 
There are various species which are usually associated with the dragon tree. one of the most commen heing Cordyline austrulis, known as "cabbage tree" (o) the residents of \ew Zealand. This plant is hardy in southern California and dees exceptionally well near the crast. In the interior valleys the trunk suffers from sunburn and is then attacked hy horers 


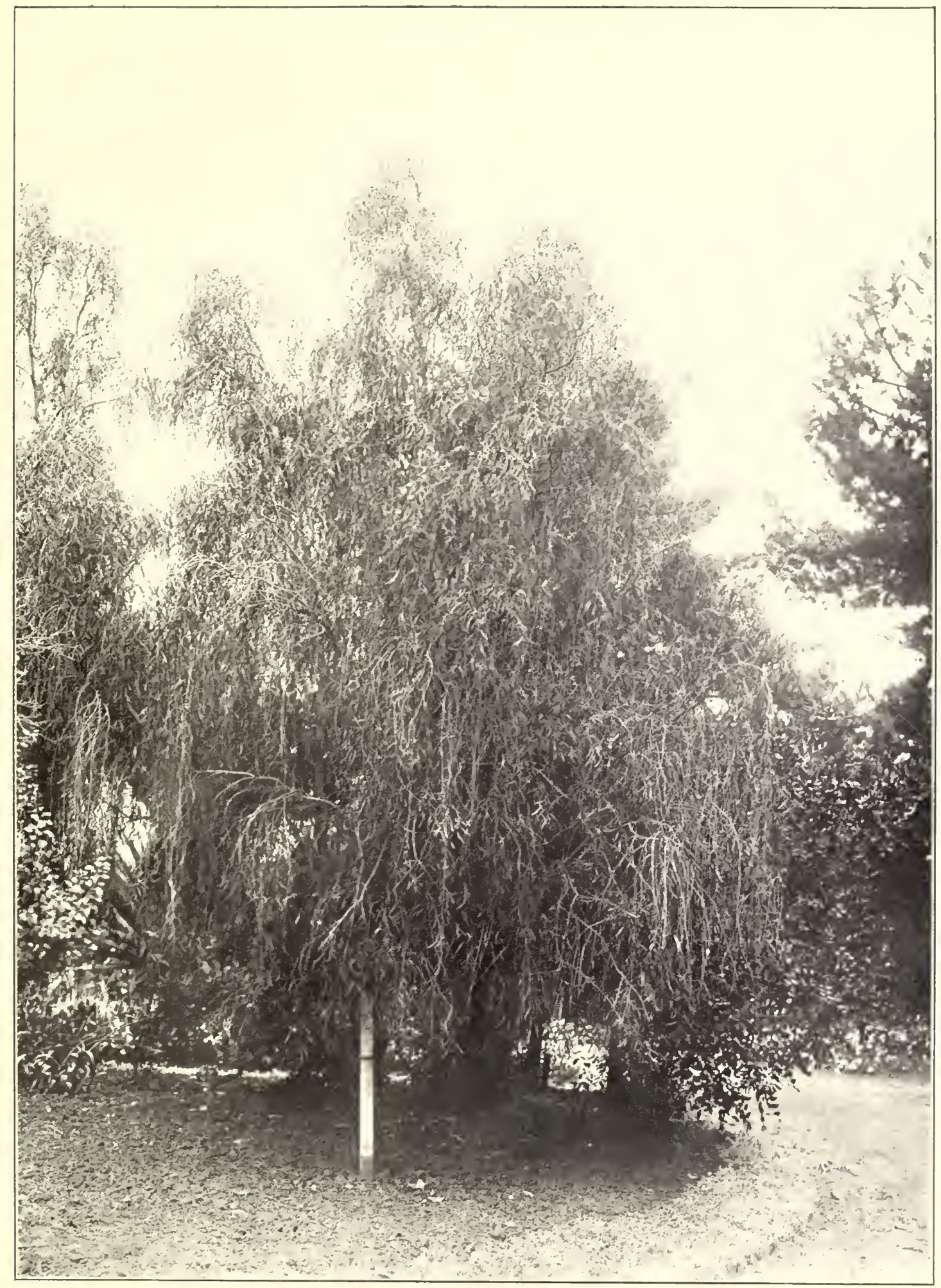

Plate 101. WEEPING PITTOSPORLIM. Goleta.

A native of the deserts of Australia which has much the habit of the weeping willow. 


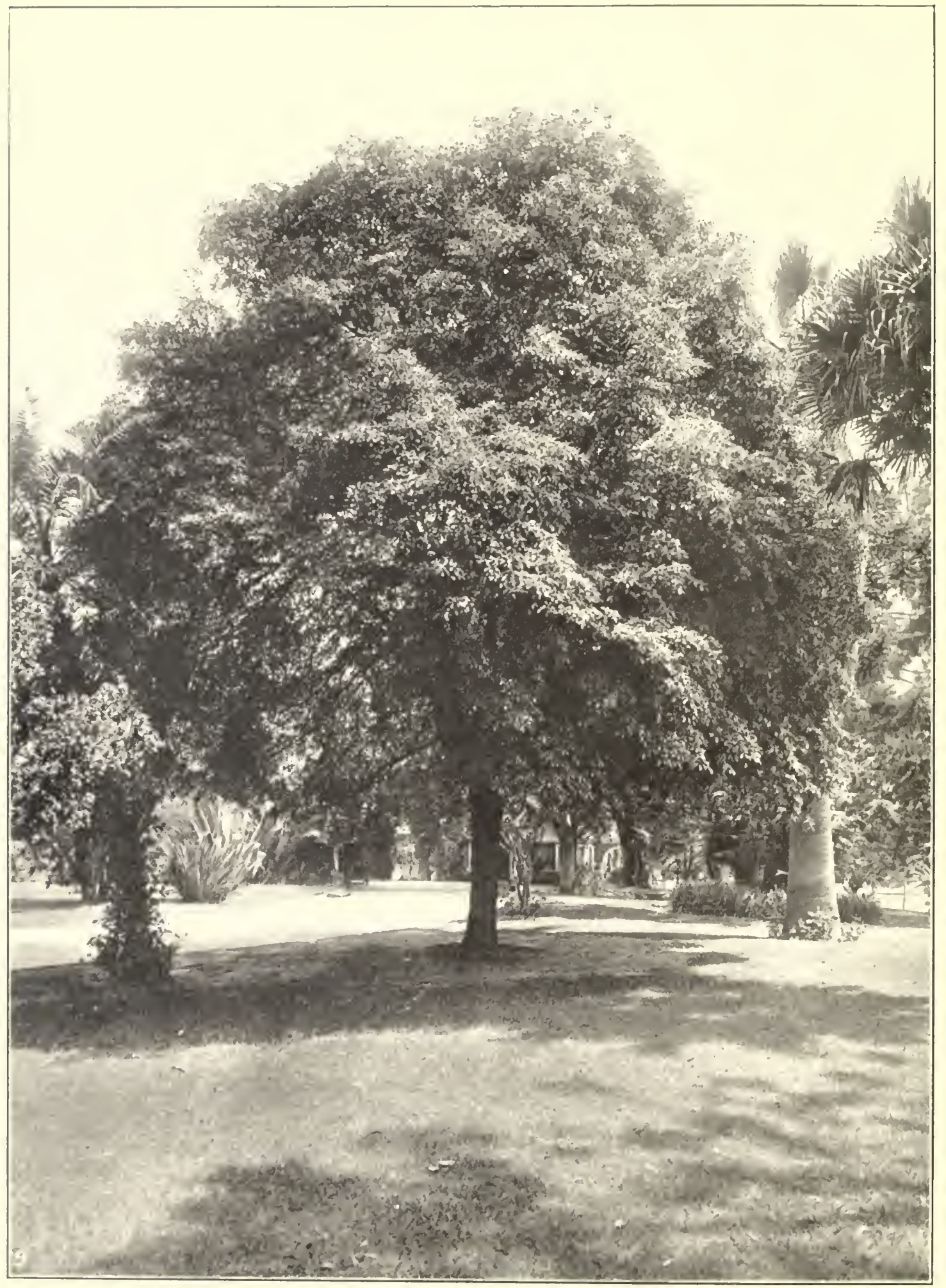

Plate 102. VICTORIAN BOX. Los Angeles.

One of the muttosporums of Australia which is much used for hedges. H reaches tree size in southern California where it is a tavorite because of the beauty of its foliage and flowers. 


\section{PAR'T II}

\section{TREE LISTS FOR DIFFERENT REGIONS OF CALIFORNIA}

The following lists may be of assistance in making selections of trees for areas having similar growing conditions. They should be used, however, with great caution because of the wide range of soil and climatic conditions that exist. These conditions are so variable that it is not an easy matter to judge how far given species may be suited. In using the lists given, consideration must be given to the results shown by trees in the neighborhood where it is proposed to plant the desired species.

It is impossible to give lists that will hold for all parts of California. Detailed inquiry must be made in each case. The State Forester will be glad to offer advice about the species of trees to select for various parts of the state. In general, the following points may be used as guides in making selections.

I. Do not select species that need abundant soil moisture if the natural water supply is slight.

2. Plant only trees in an alkaline soil that will tolerate the amount of alkali that may be present.

3. Do not plant species characteristic of arid sections of the state in semihumid regions and do not plant those characteristic of humid regions in arid sections. Use the native vegetation as a guide and plant only those trees that will harmonize with it.

No effort is being made to classify all the trees given in this publication under the lists given since there are many exotics described concerning which little is known. Chiefly those trees are given which have been well tried out and which can be secured as a rule from nurserymen. 


\section{REGION I}

\section{SACRAMENTO AND SAN JOAQUIN VALLEYS}

Highway Trees

Lonion Plane
California Black 11 alnut
English Elm
Anerican Elm
Black Locust
Blue Gum
Red Gum
Forest Gray. Gum
Olive

European Buckere

Lombardy Poplar

Carolina Poplar

Silver Mlaple

Norway Maple

Arizona Ash

California Live Oak

California Sycamore

Lawn and Street Trees

Deolar Cedar
Monkey Puz=le
Aorfolk Island Pine
Hawthorn
Bur ()ak
Cork Oak
Honey Locust
Crape Myrtle
Albizzia
White Fir
Italian Cypress

Incense Cedar

Big Tree

Camphor

Tulip Tree

London Plane

Italian Stone Pine

Valley Oak

Pin Oak

Italian Chestnut

I rish Yew

Arbor Vitae

Windbreaks

Red Gum

Desert Gum

Blue Gum

Coulter Pine

Monterey Cipress 


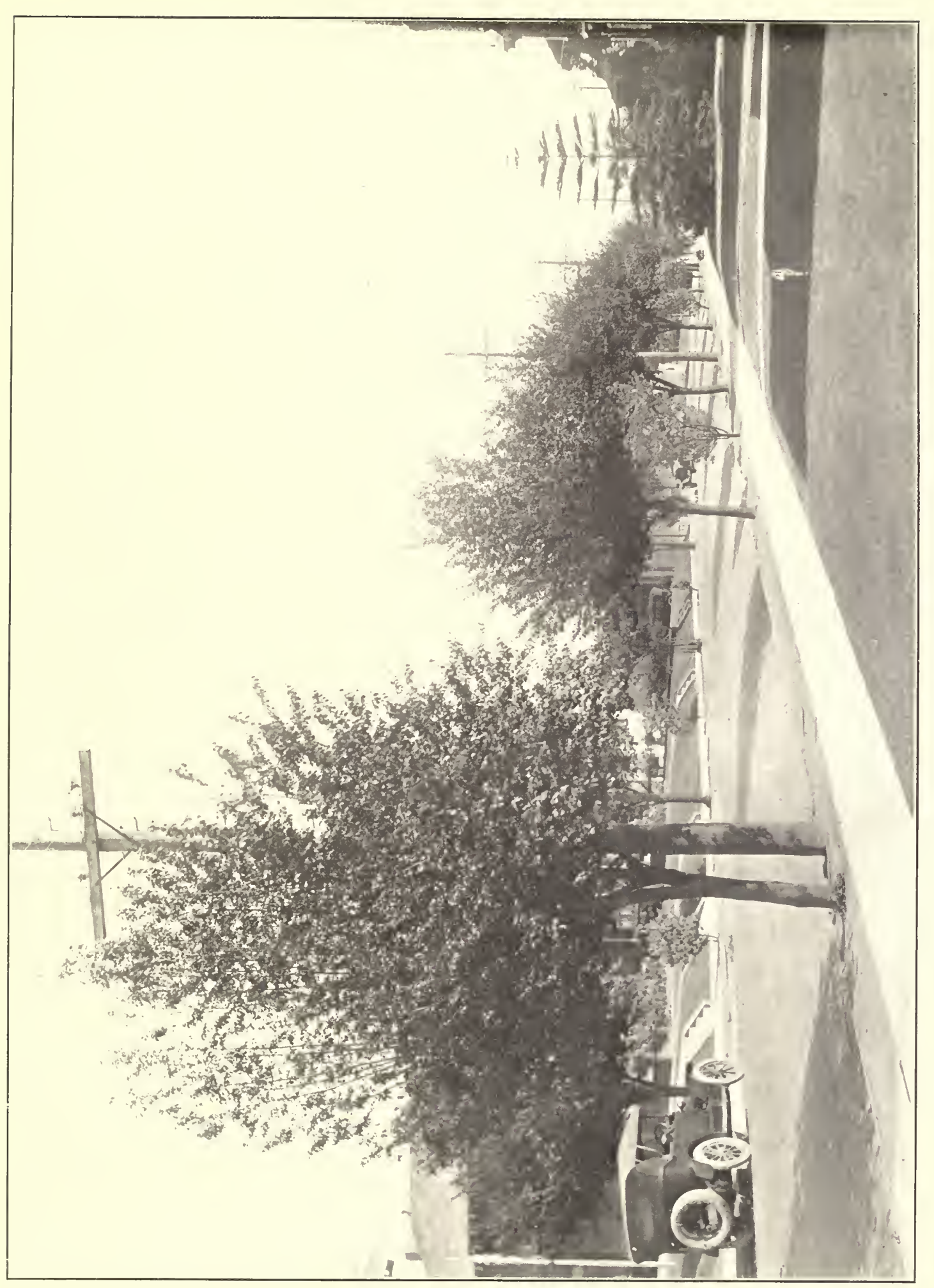




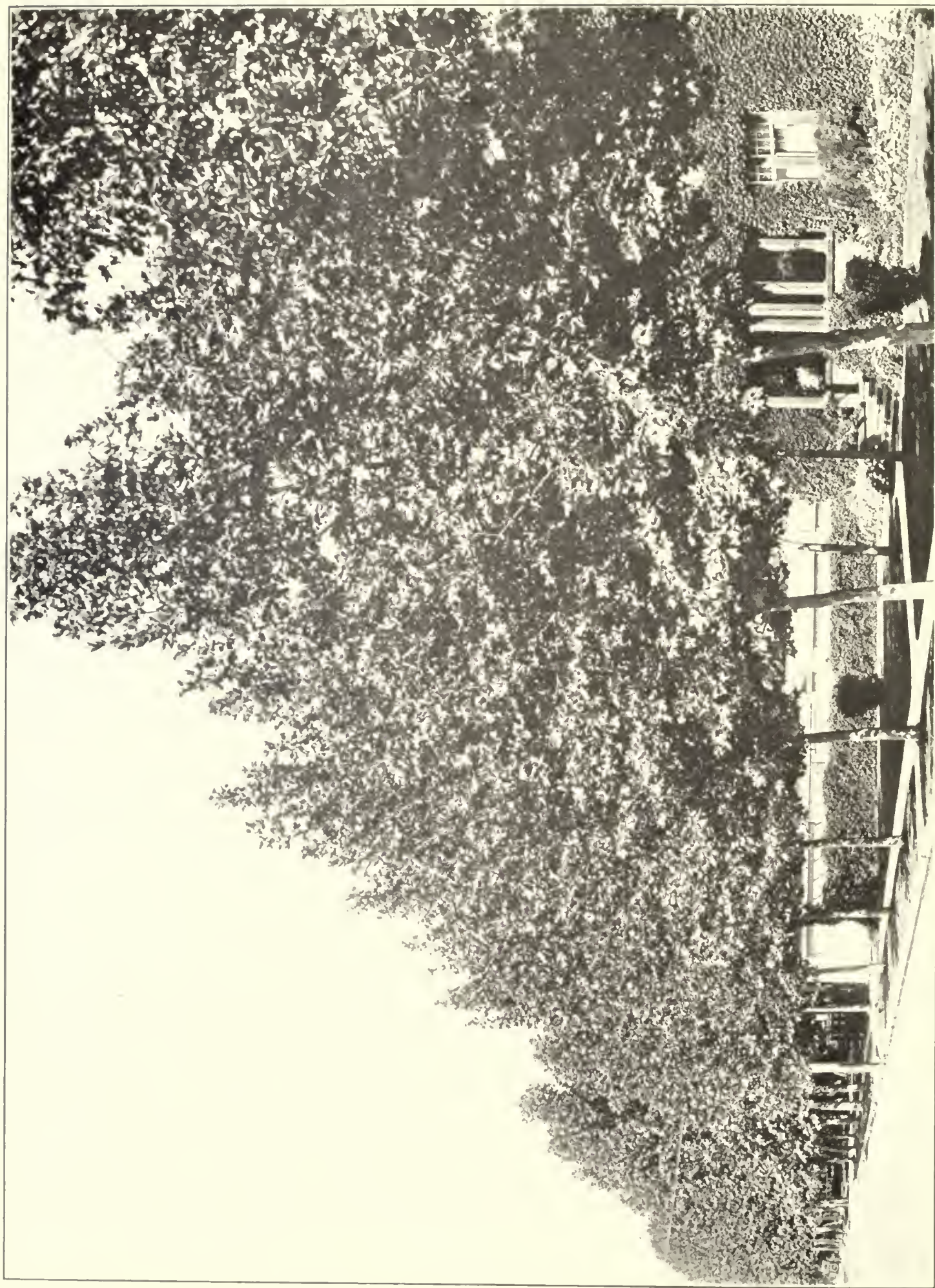




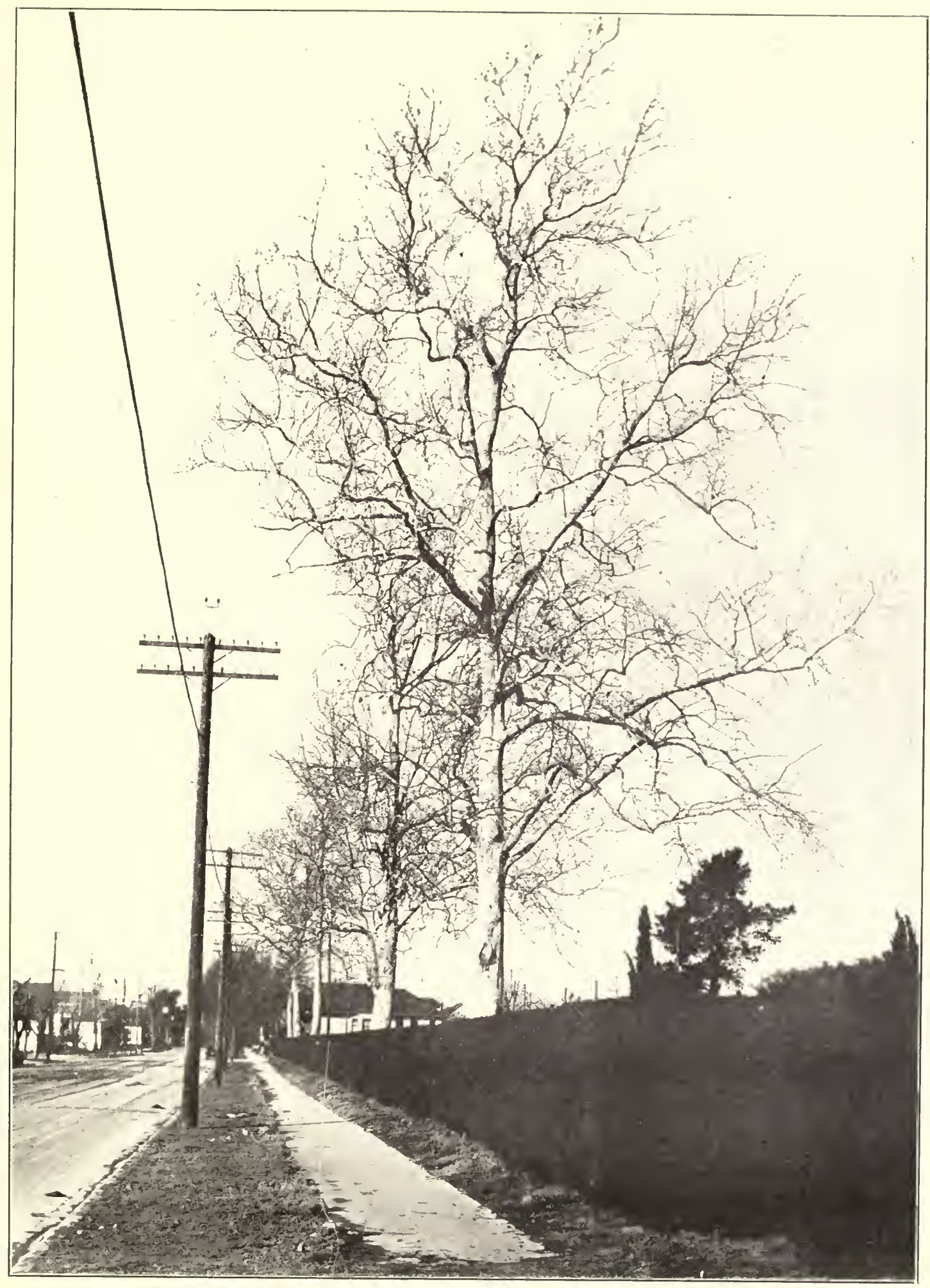

Plate 105. CALIFORNIA SYCAMORE. Sacramento.

"In the outskirts of the village
On the river's winding shores,
Stand the Occidental plane trees.

Stand the Occidental plane trees,
Stand the ancient sycamores."

-Whittier. 


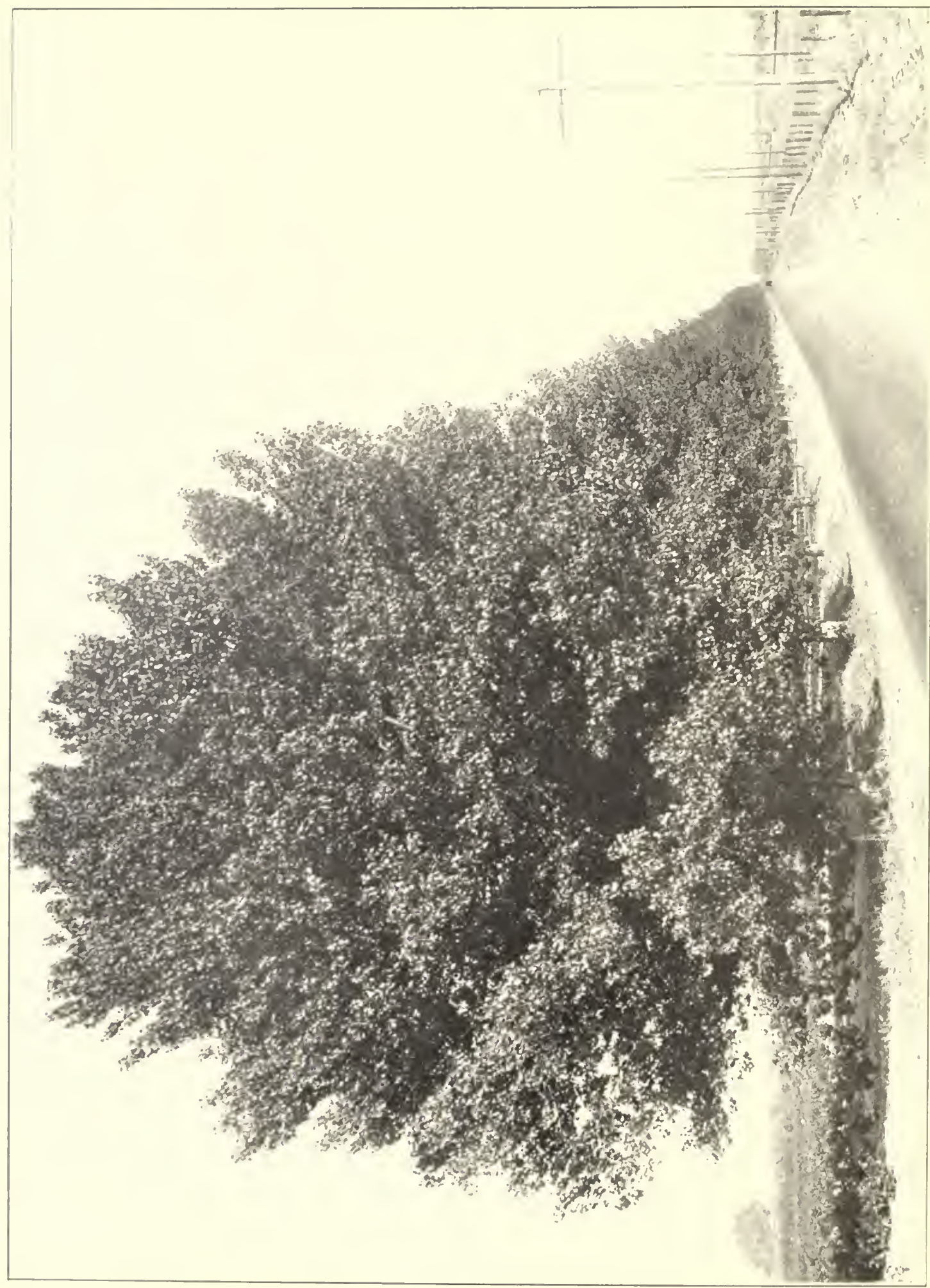

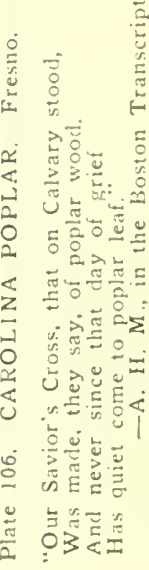




\section{REGION II}

\section{COASTAL}

\section{Highway Trees}

Coast Redwood

California Black Walnut

California Live Oak

Lombardy Poplar

Carolina Poplar

London Plane

English Elm

Big-leaf Maple

Blue Gum

Red Gum

European Linden

American Elm

\section{Lawn and Street Trees}

London Plane

California Sycamore

Silver Maple

Tulip Tree

Purple-leaved Plum

White Birch

Bur Oak

English Elm

Madrona

American Elm

California Laurel

Copper Beech

European Buckeye

Pink-flowering Locust

Hawthorn

Bull Bay Magnolia

Blackwood Acacia

Colorado Blue Spruce

Deodar Cedar

Empress Tree

Ginkgo

Lawson Cypress

Bald Cypress

Aleppo Pine

English Holly

Norway Spruce

Douglas Fir

Windbreaks

Monterey Pine

Monterey Cypress

Coast Redwood

Red Gum

Incense Cedar

Lombardy Poplar 
Highway Trees

London Plane

Bur ()ak

California Live Oak

Carolina Poplar

Lawn and Street Trees

European Linden

Tulip Tree

Deodar Cedar

Juniper

Big Tree

Windbreaks

Incense Ceclar

Monterey Pine

Silver Maple
Silver Maple

English Elm

American Elm

Lombarly Poplar

Incense Ceclar

Silver Maple

Lawson Cipress

Colorato Blue Spruce

Lombardy Poplar

Austrian Pine

Carolina Poplar 


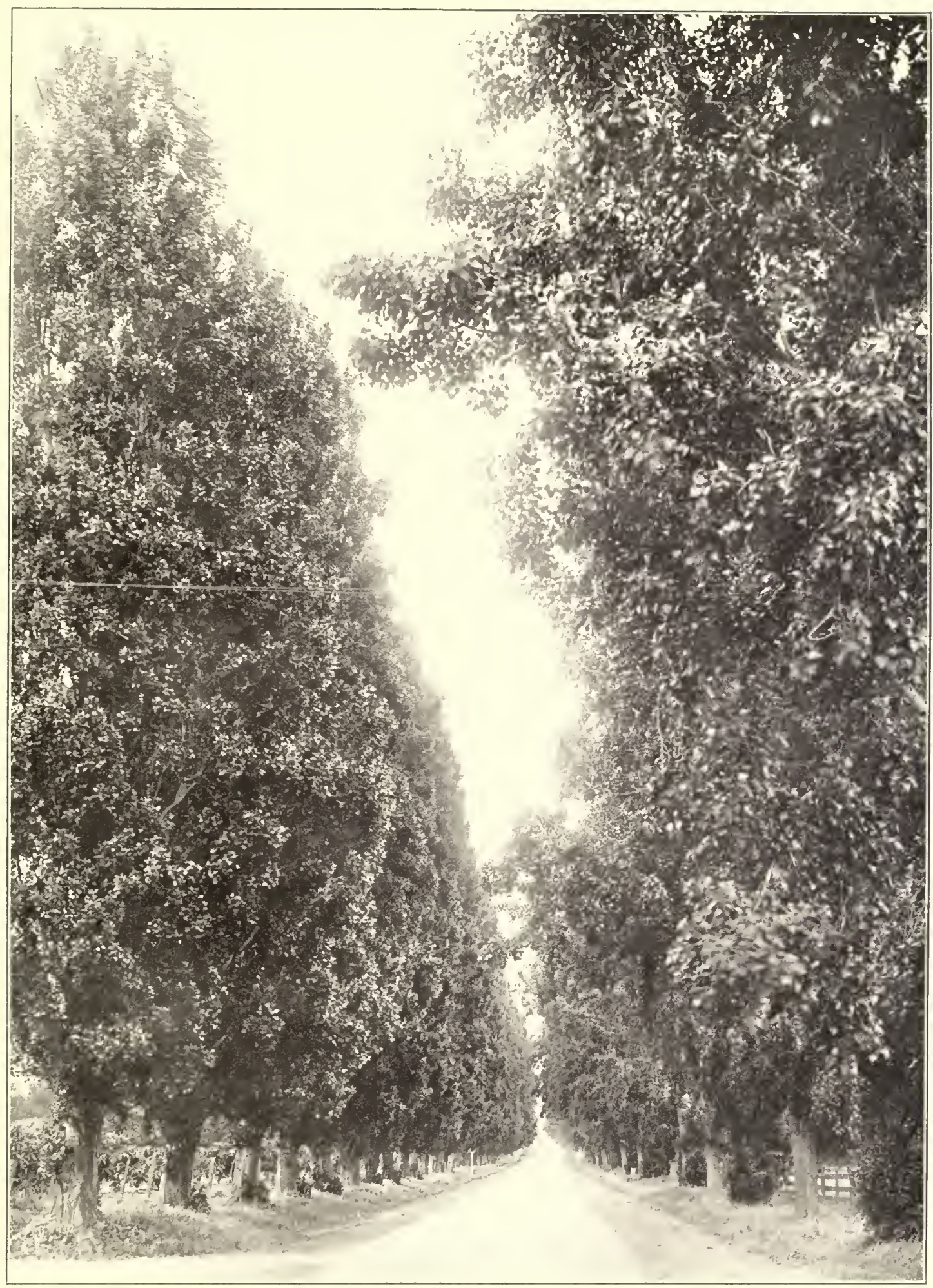

Plate 107. LOMBARDY POPLARS. Santa Barbara.

"Now with the breath of coming rain

The poplars sway in troubled row,

Like old wives, rocking to and fro

In pain ;

They shake their heads in shocked surprise

And whisper underneath their breath,

Like mourners in a house of death:

Then lift their aprons to their eyes 


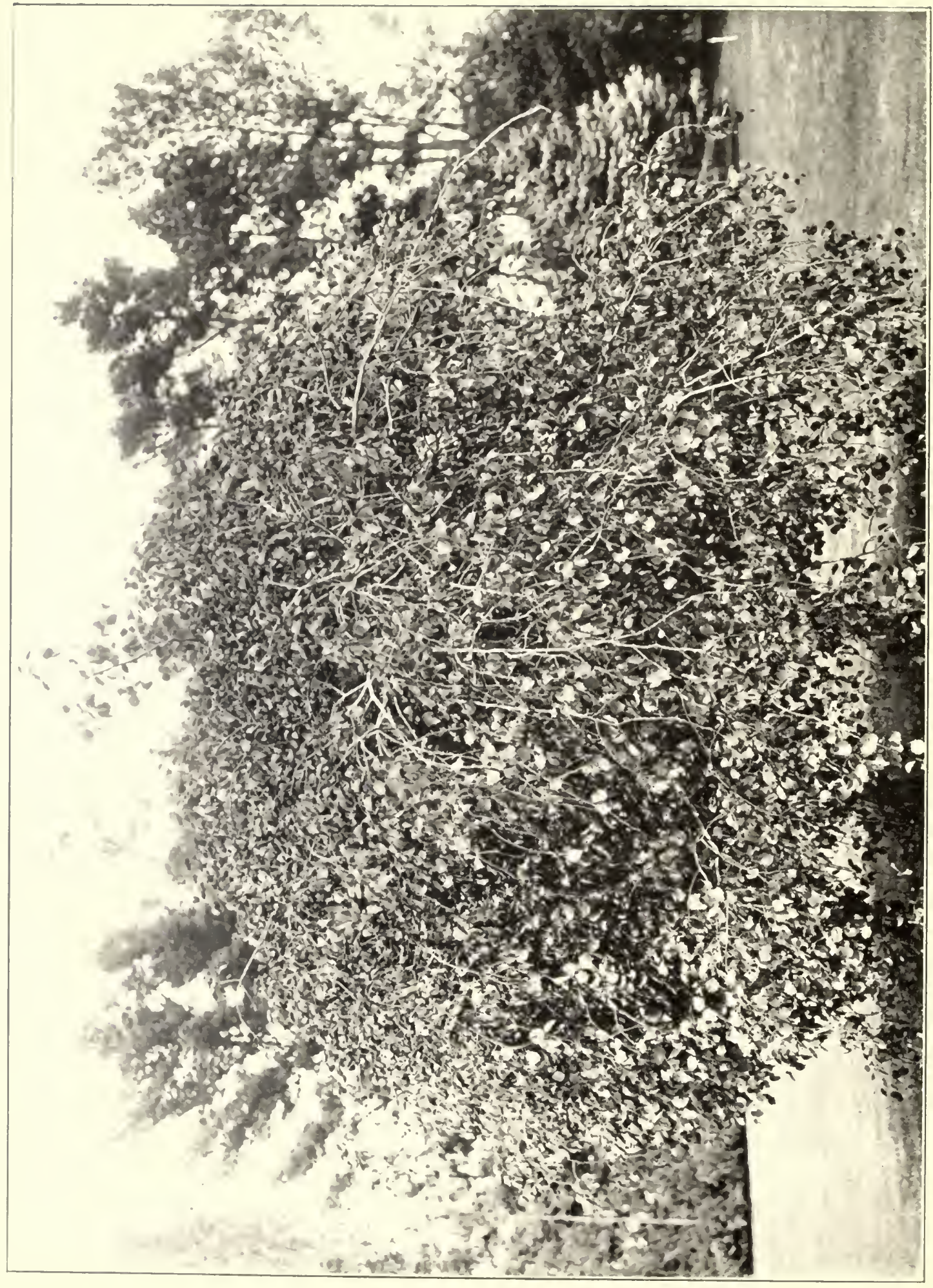




\section{REGION IV}

\section{SOUTHERN CALIFORNIA}

Highway Trees

Arizona Ash

Red Gum

Arizona Cypress

Sugar Gum

Deodar Cedar

Lemon-scented Gum

Cork Oak

Bull Bay Magnolia

Street and Lawn Trees

Norfolk Island Pine

Deodar Cedar

Jacaranda

Brazilian Pepper

Coral Tree

Torrey Pine

Orchid Tree

Island I ronwood

Rubber Tree

Victorian Box

Camphor

Bottle Tree

Flame Tree

Brisbane Box

Canary Island Pine

Australian Brush Cherry

Bailey's Acacia

Beefwood

Scarlet-flowering Gum

Carob

Catalpa

Catalina Cherry

Lawson Cypress

Blue Cypress

Italian Chestnut

Windbreaks

Monterey Cypress

Monterey Pine

Red Gum

Australian Beech 


\section{ALKALI RESISTANT TREES}

\section{STRONGLY RESISTANT}

Catalina Cherry

Valley White Oak

IIillow

Tamarisk

Bottle Brush
Nulberr.

Lombardy Poplar

Carolina Poplar

Red Gum

\section{FAIRLY RESISTANT}

Blackwool Acacia

Arizona Ash

Big Leaf Maple

Honey Locust

Beefwoud

California Black IValnut

Caroh

Camphor

Aleppo Pine

Italian Cypress

Cork Oak

English Elm

Black Locust

Canary Island Pine 


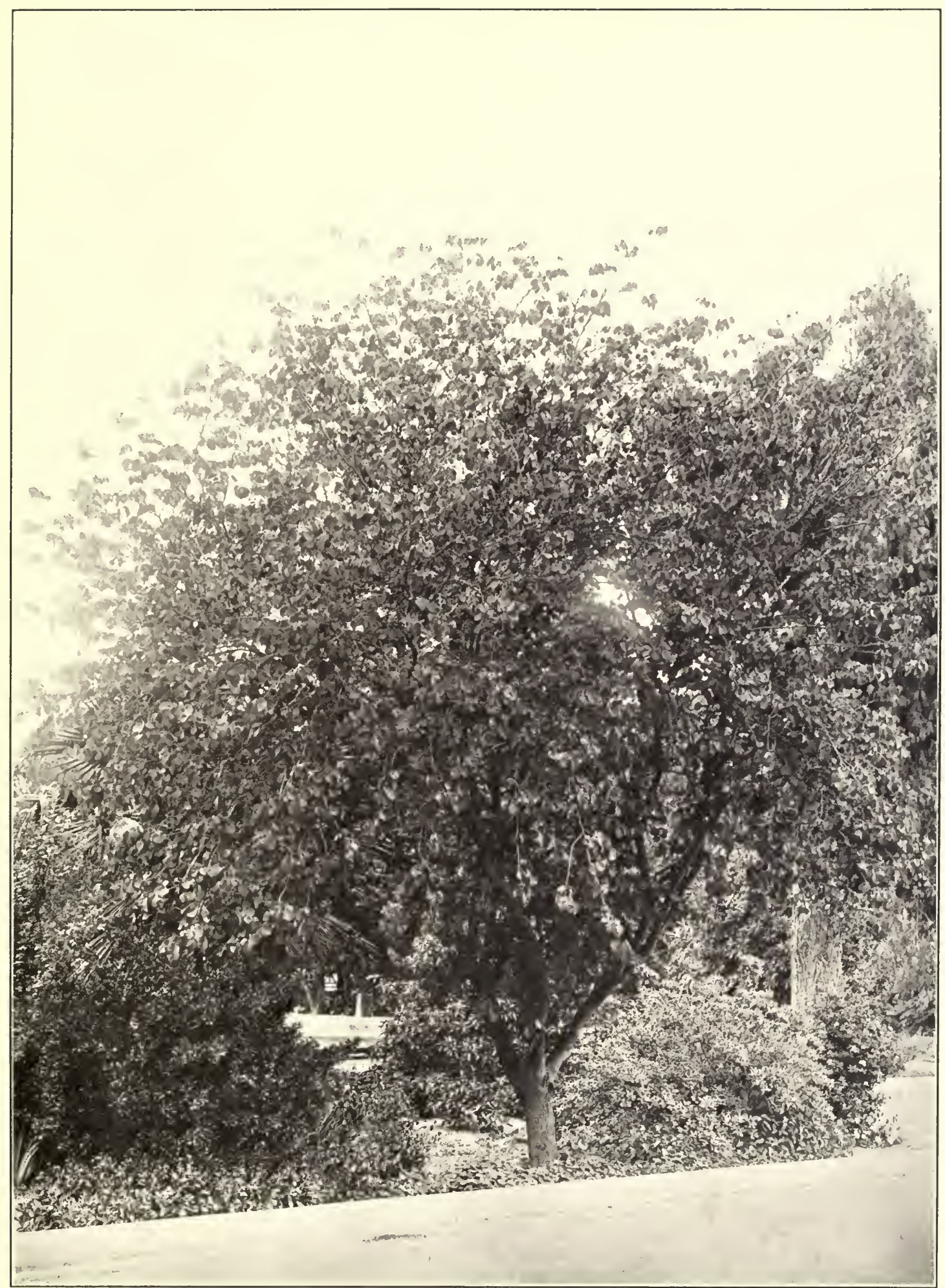

Plate 109. RED BUD. Pasadena,

A small tree bearing innumerable peashaped pink flowers before the leaves appear. The pods remain all summer, adding to its picturesque appearance. 


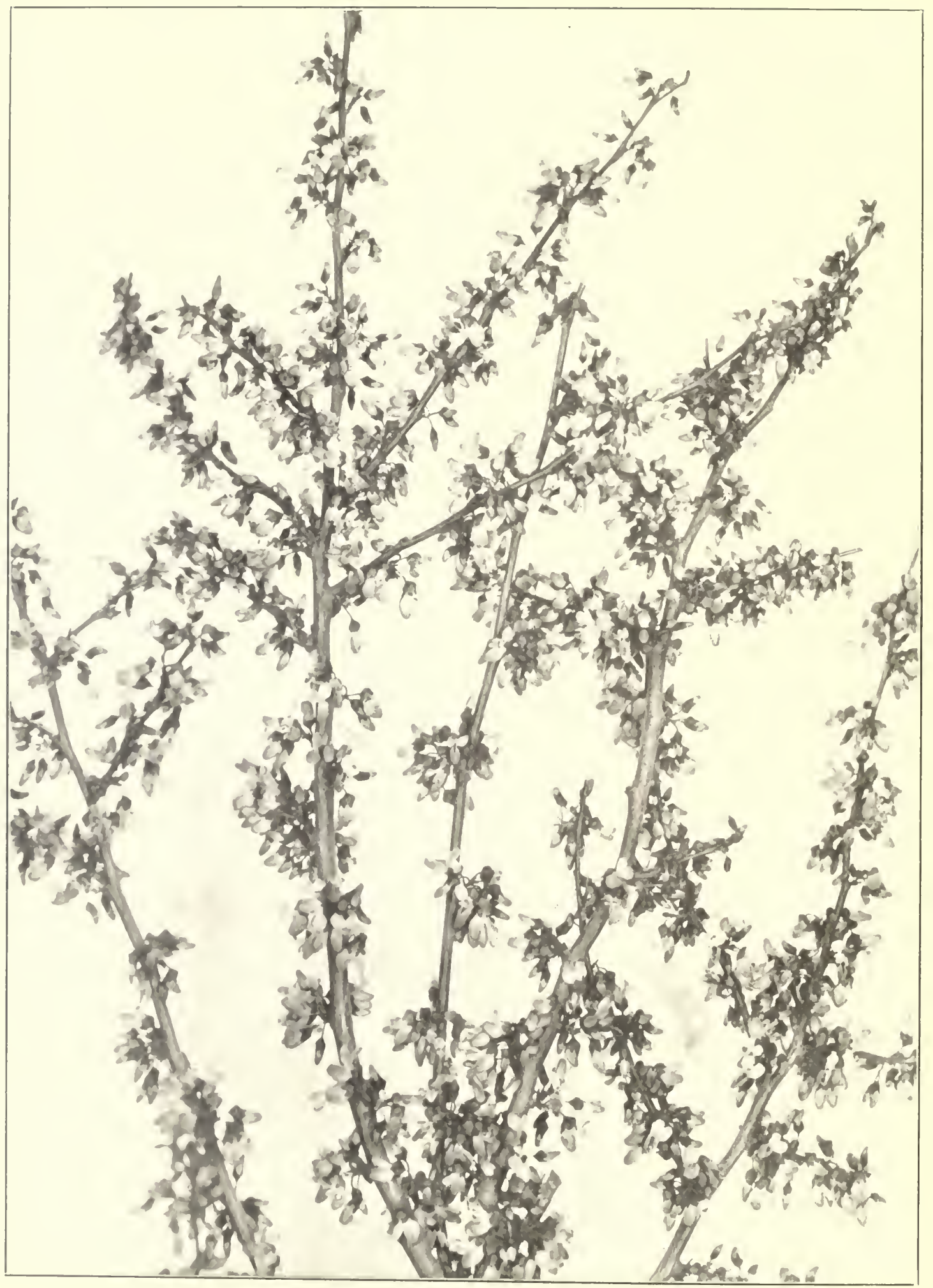

Plate 110. RED BUD BLOSSOMS. Capay Valley. 


\section{REFERENCES}

American Forestry.

Bailey, L. H.

Standard cyclopedia of horticulture.

Boulger, G. S.

Familiar trees.

Fernow, B. E.

Care of trees.

Franceschi, C. F.

New and little known trees suitable for southern California avenues. Hall, H. M.

Studies in ornamental trees and shrubs.

Jepson, Willis Linn.

Silva of California.

McLaren, John.

Gardening in California.

Morrison, Ben Y.

Street and highway planting, Bulletin No. 4, California State Board of Forestry.

Mulford, F. L.

Street trees, Bulletin No. 816, United States Department of Agriculture.

Nursery Catalogues.

California Nursery Company.

Theodore Payne.

Pythian, J. Ernest.

Trees in nature, myth and art.

Sargent, Charles Sprague.

Manual of the trees of North America.

Simmons, J. R.

Historic trees of Massachusetts.

Solotaroff, William.

Shade trees in towns and cities.

Sudworth, George B.

Forest trees of the Pacific slope. 
"A tree's mere firewood, unless humanized,-

Which well the Greeks knew when they stirred its bark With close-pressed bosoms of subsiding nymphs,

And made the forest rivers garrulous

With babble of gods."

-Mrs. Browning. 


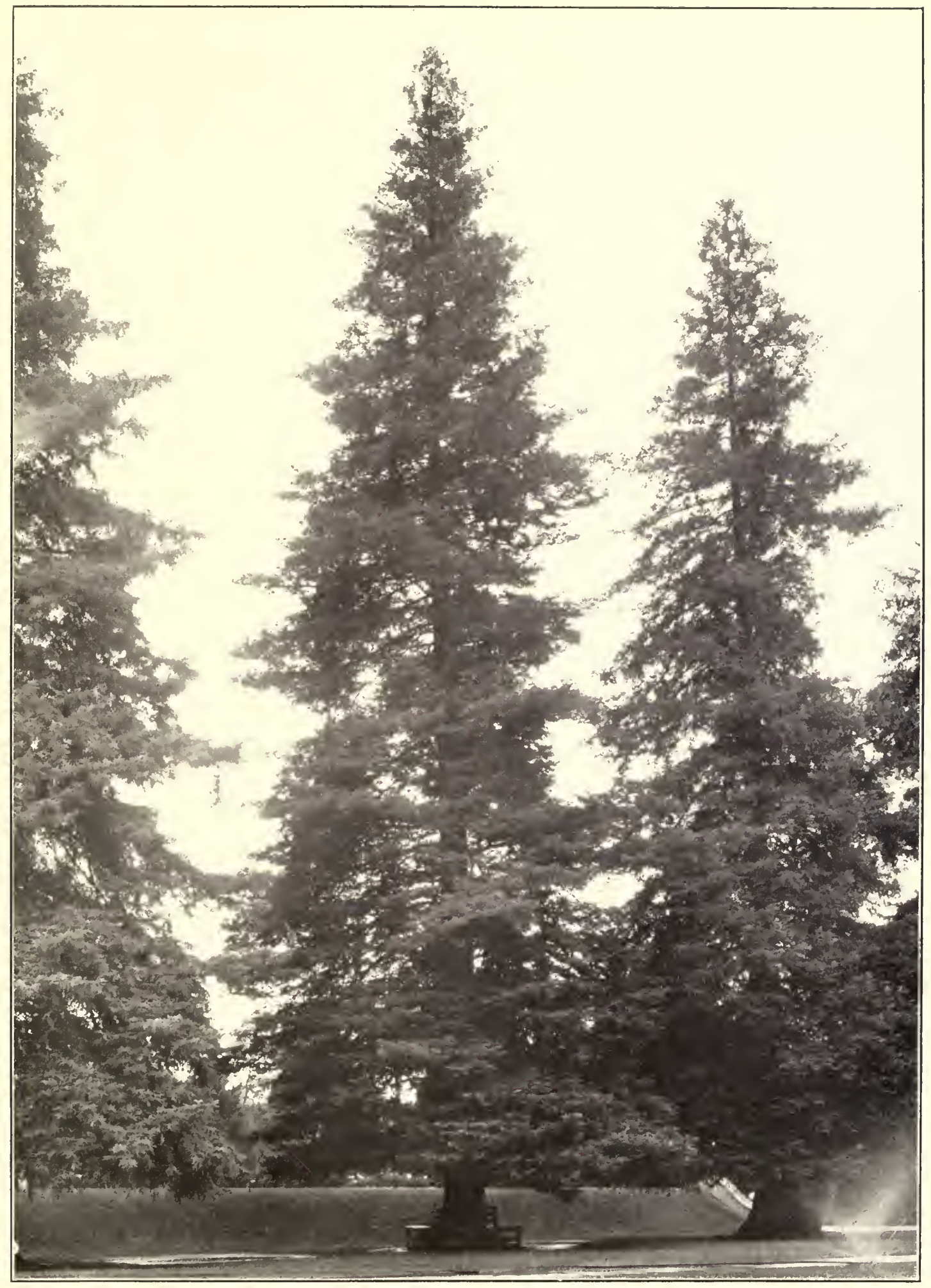

Plate 111. COAST REDWOOD: Sacramento.

Under cultivation coast redwood makes a rapid growth even when removed from the fog belt. 


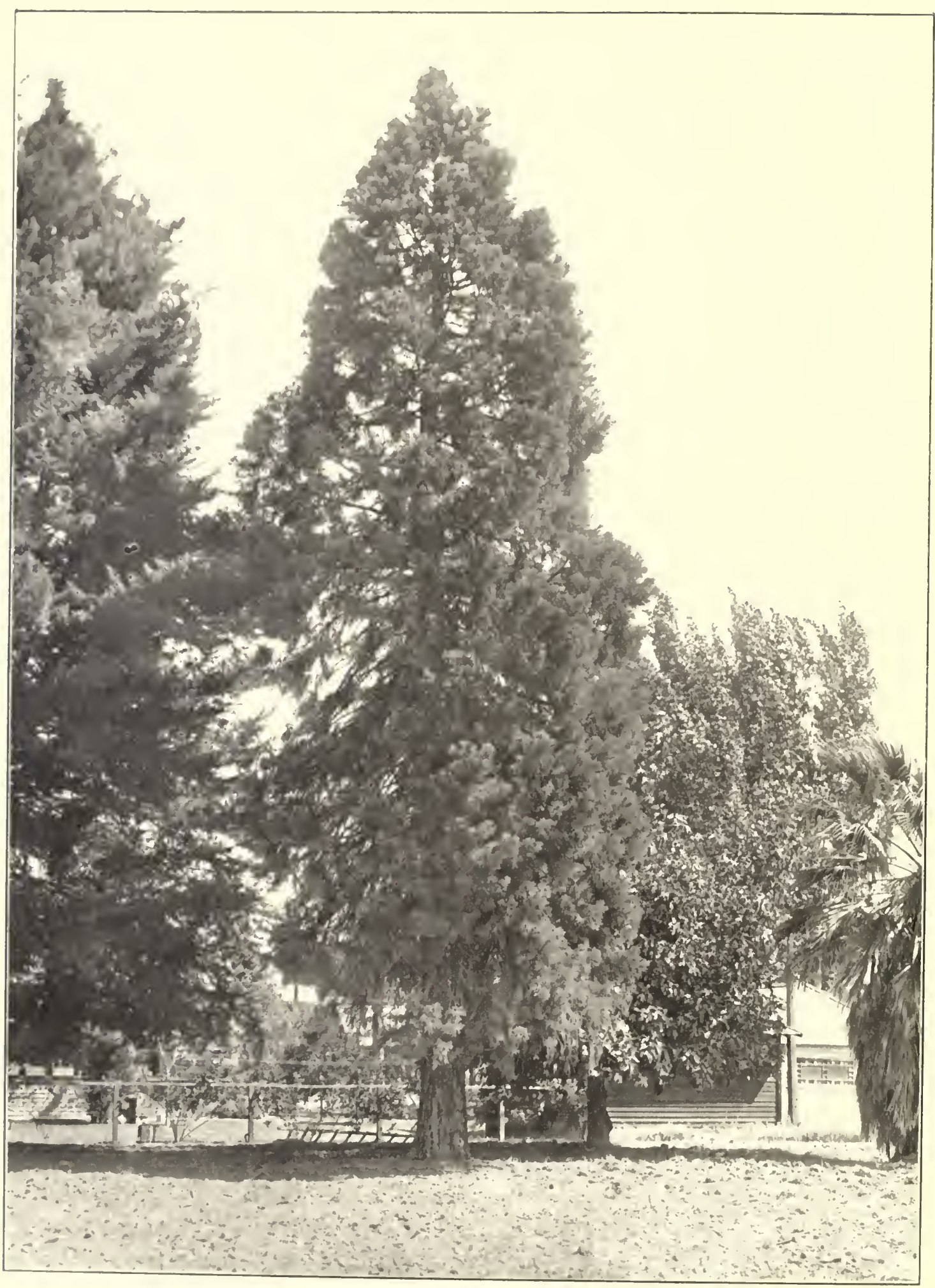

Plate 112. BIG TREE. Visalia.

"Thy sire saw the light that shone
On Mohammed's uplifted crescent,
On many a royal gilded throne
And deeds forgotten in the present.

- Bret Harte. 



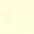




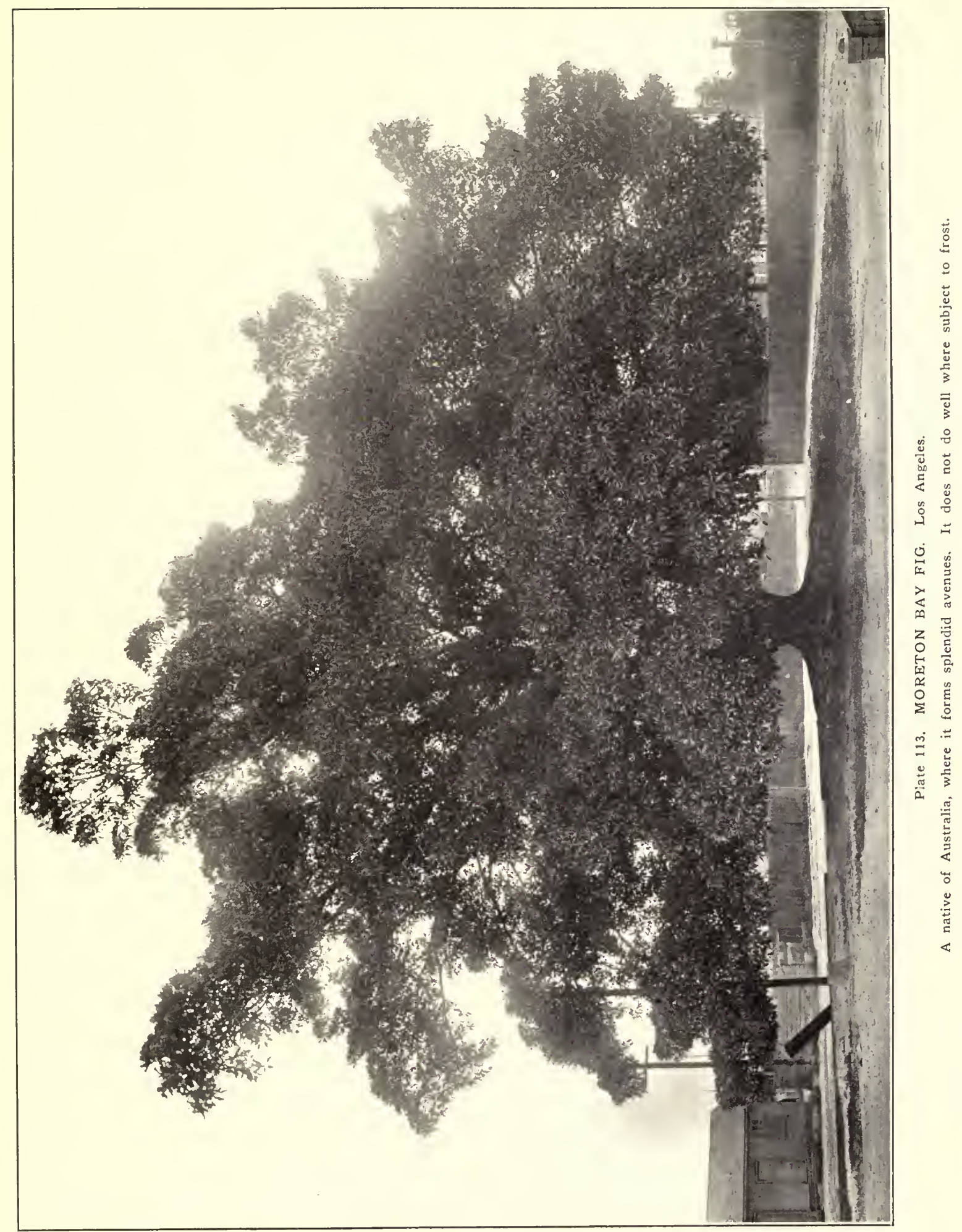




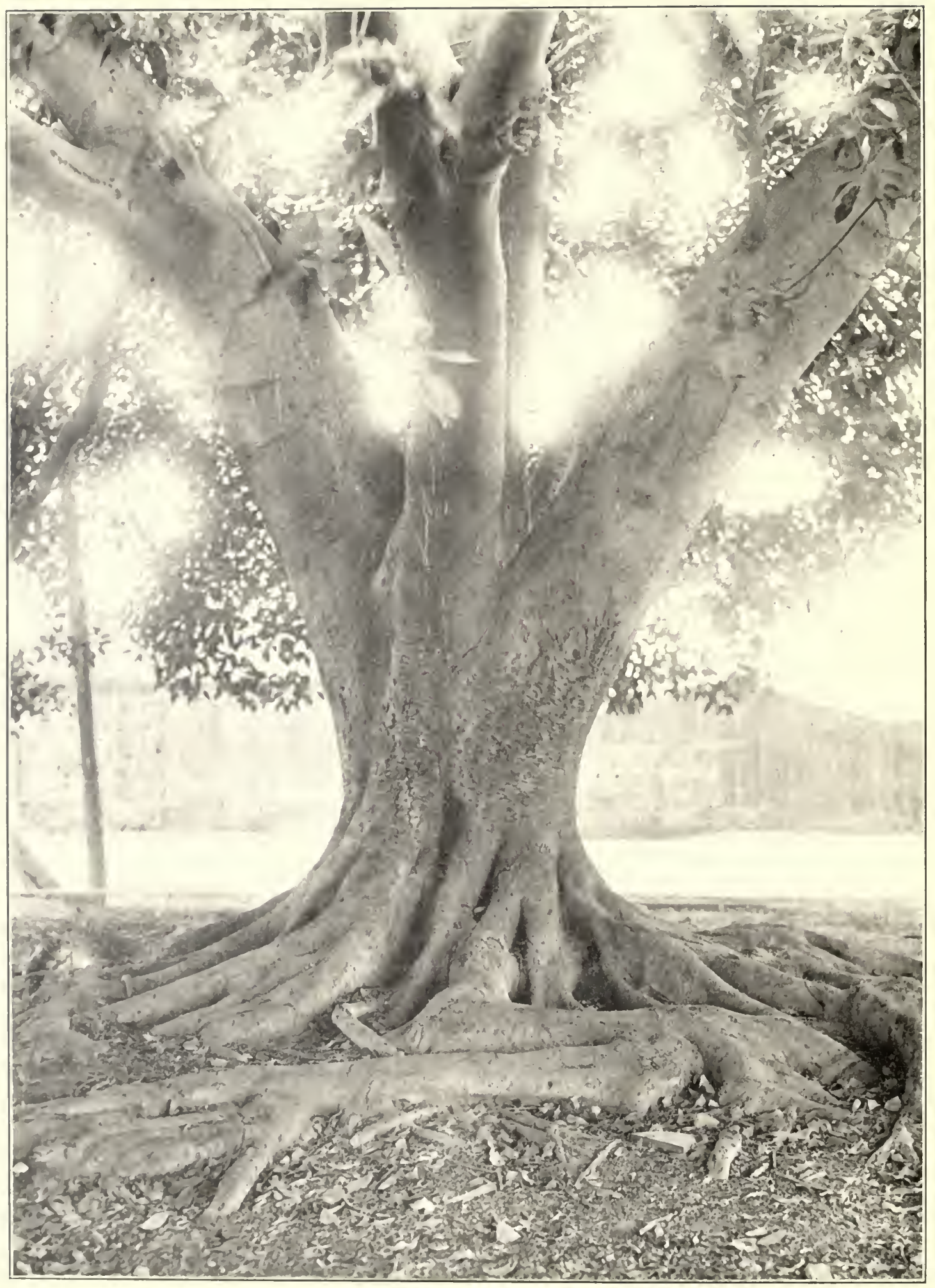

Pate 114. MORETON BAY FIG TRUNK. Los Angeles.

The fantastic development of this tree's buttressed roots gives them a snake-like appearance. 


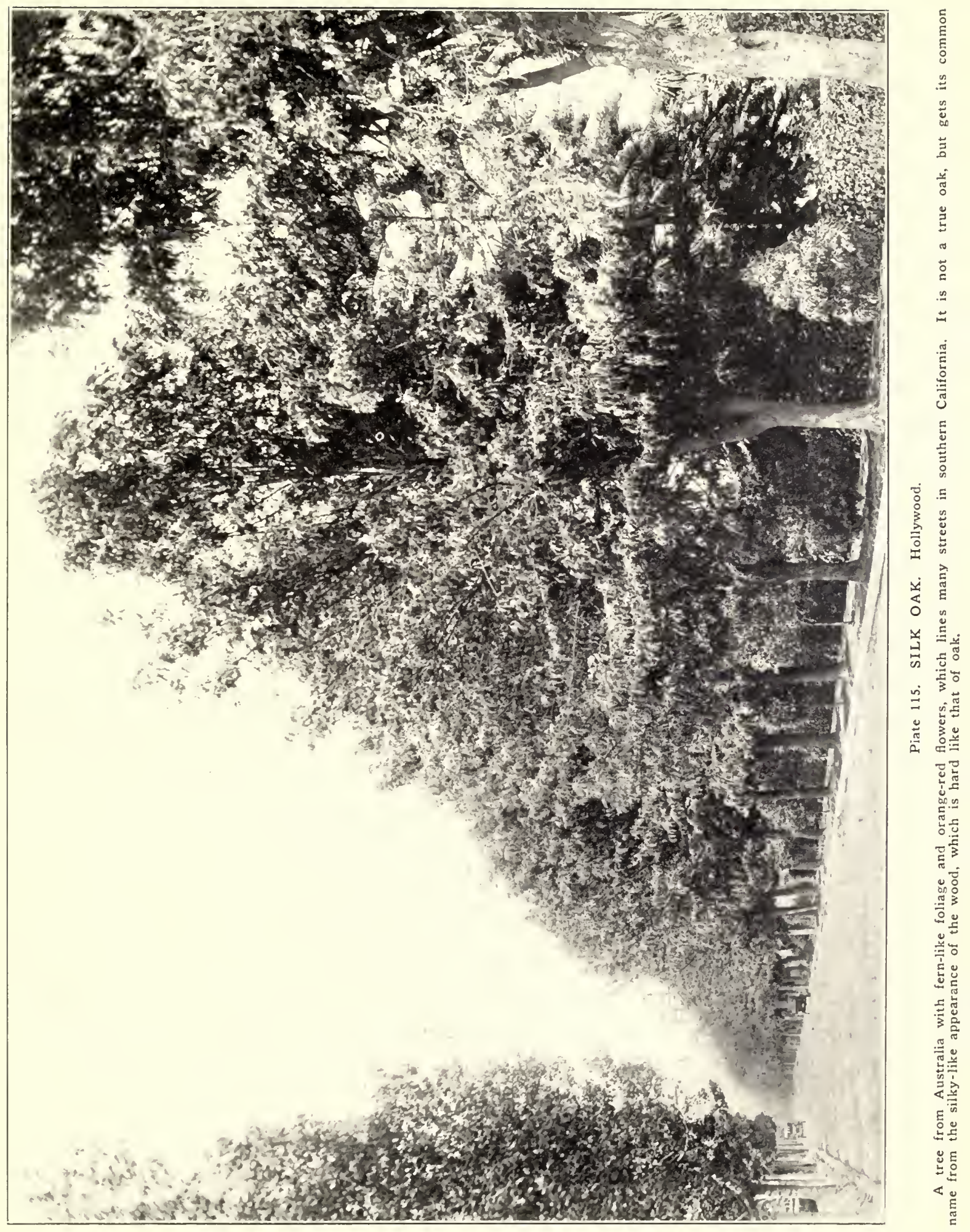




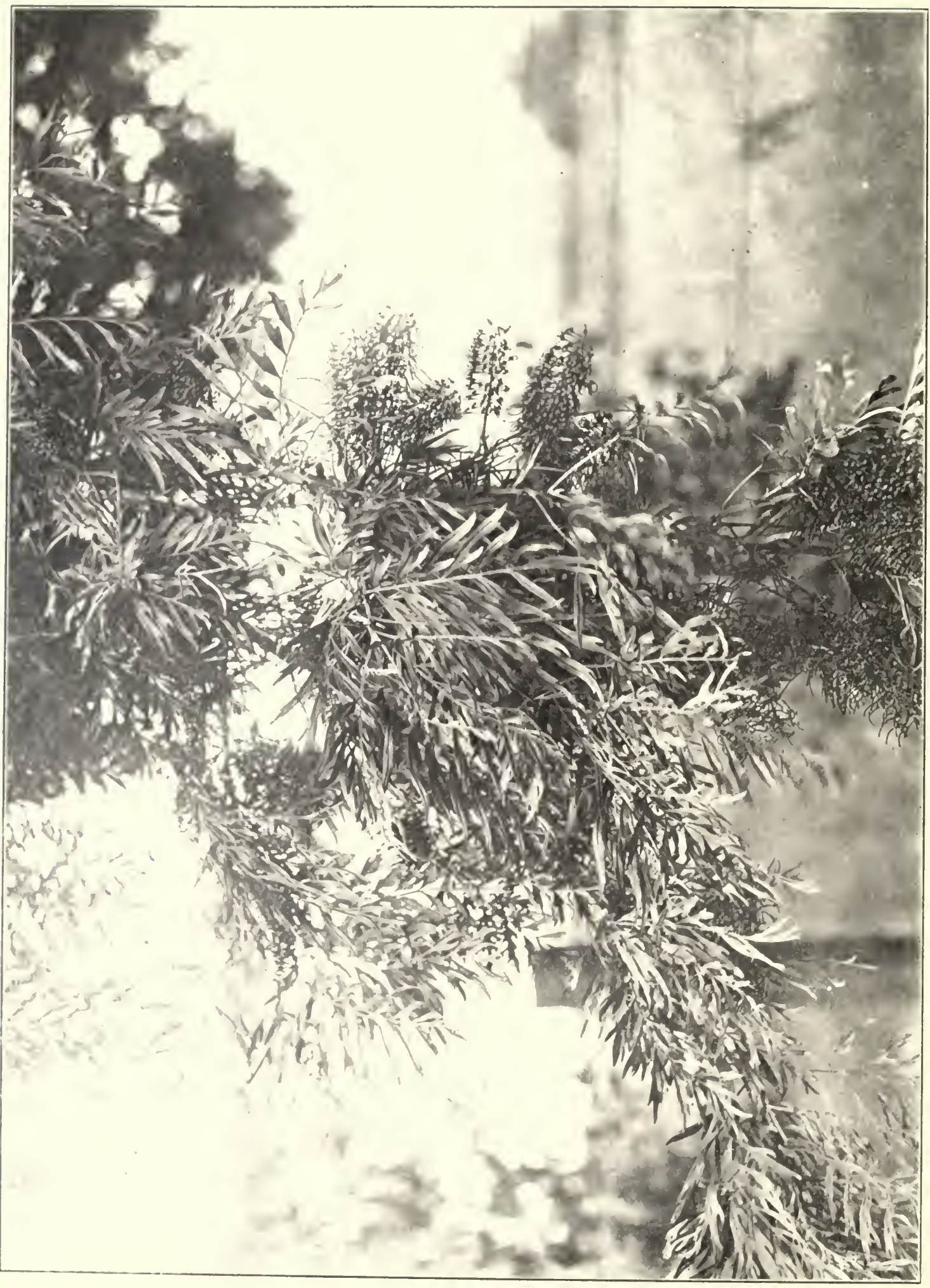




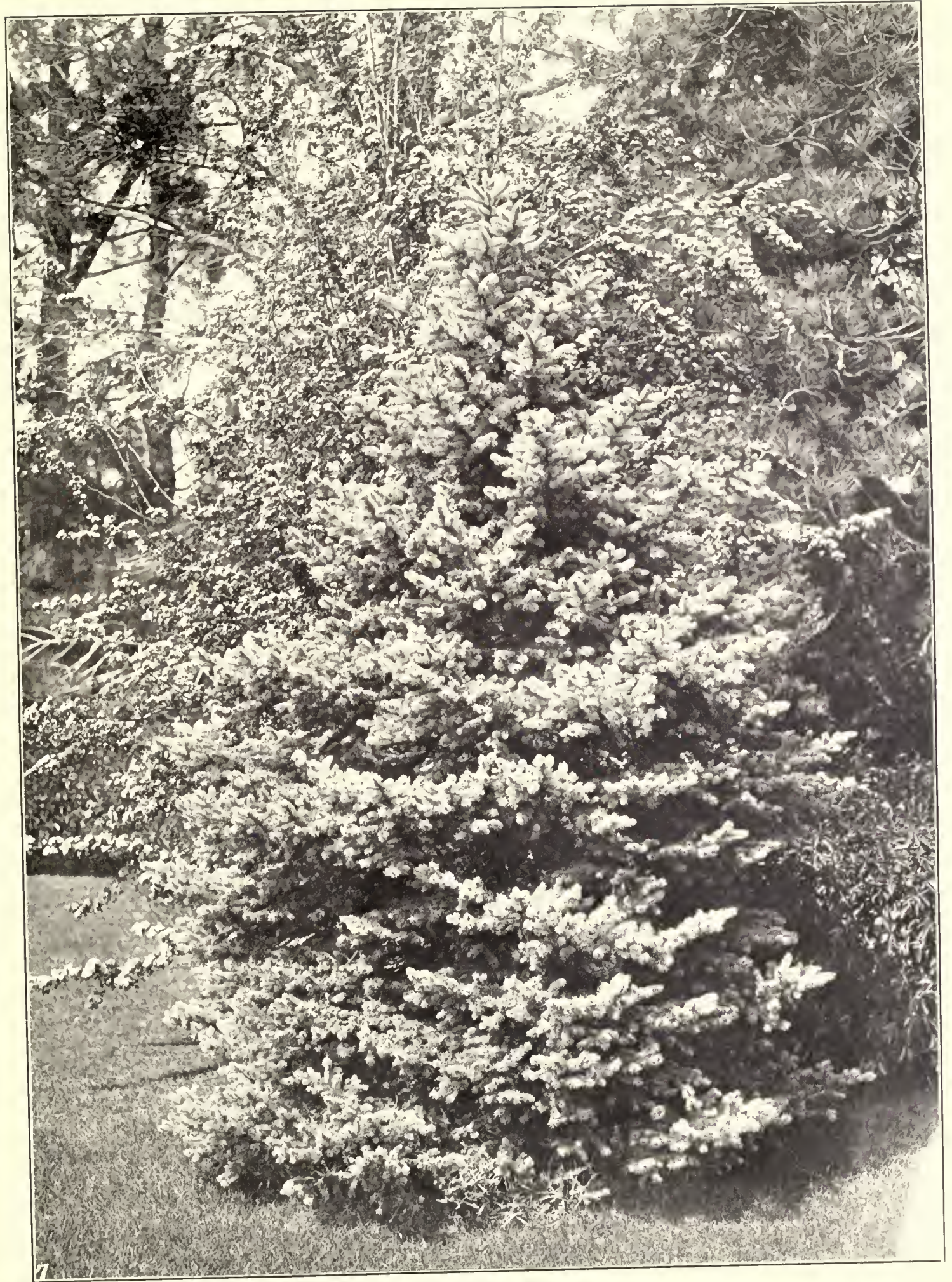

Plate 117. COLORADO BLUE SPRUCE. Burlingame. 


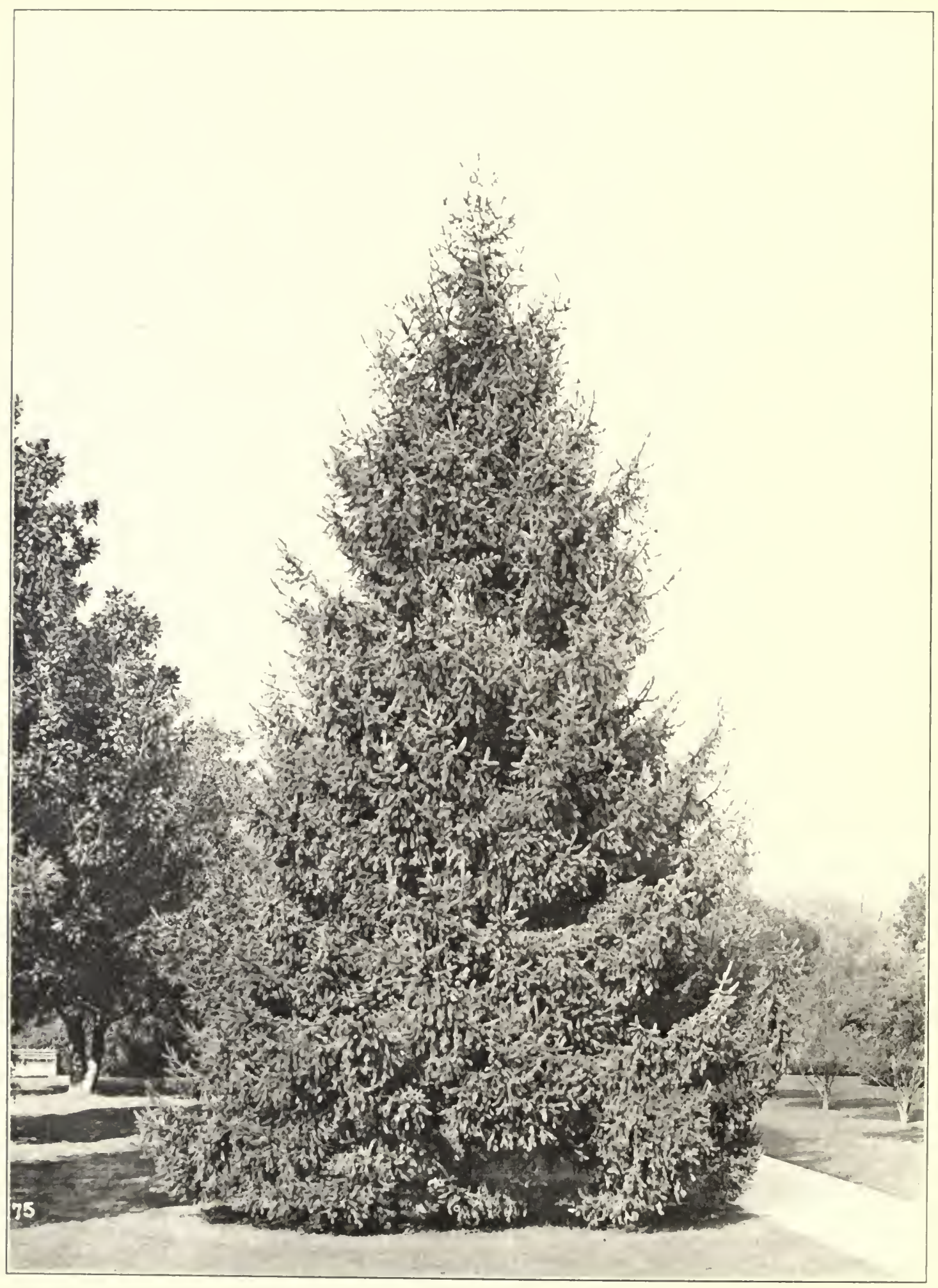

Plate 118. NORWAY SPRUCE. Sacramento.

The original Christmas tree of northern Europe. It is a graceful tree, the branches of which assume a drooping habit with age. 


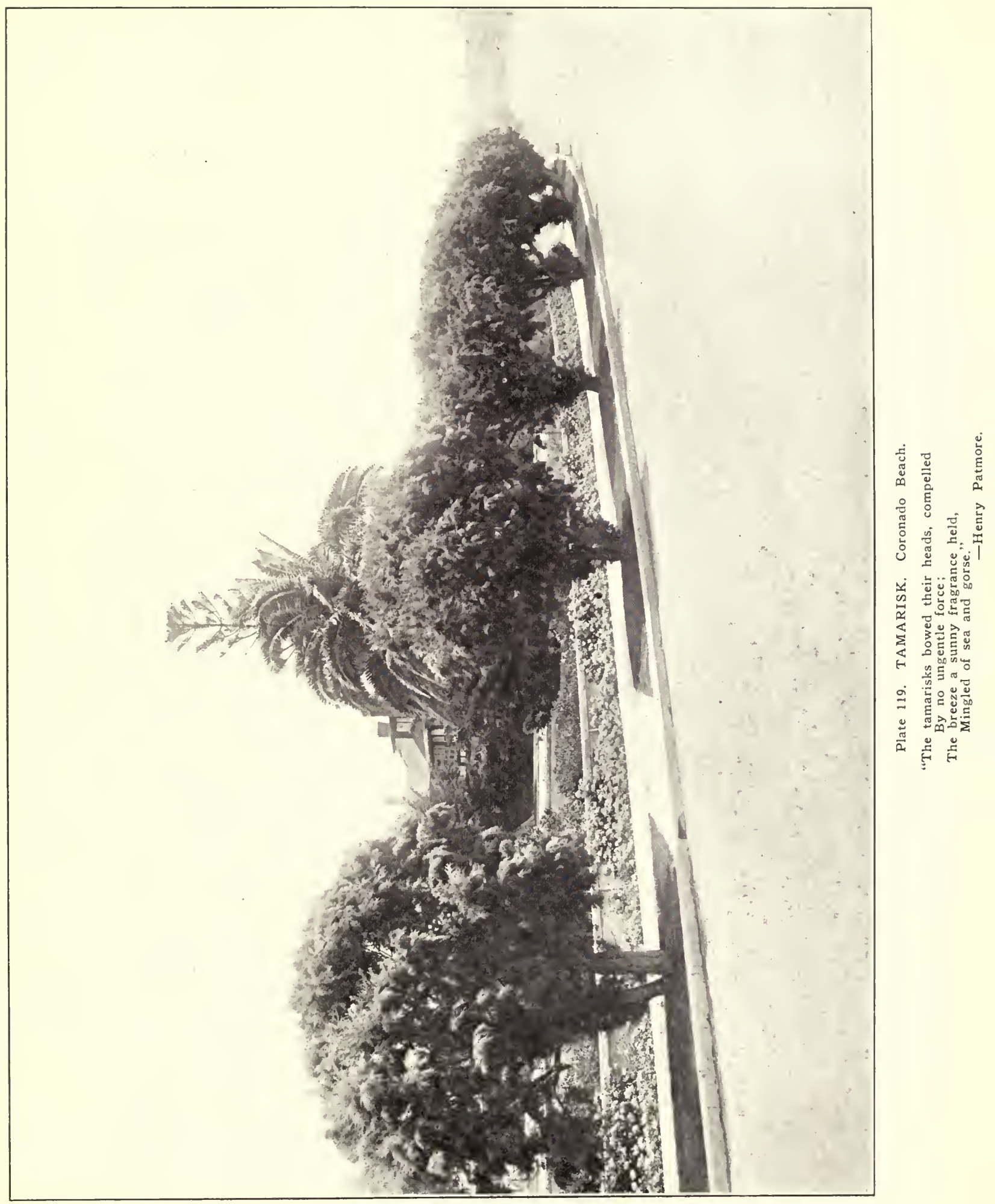




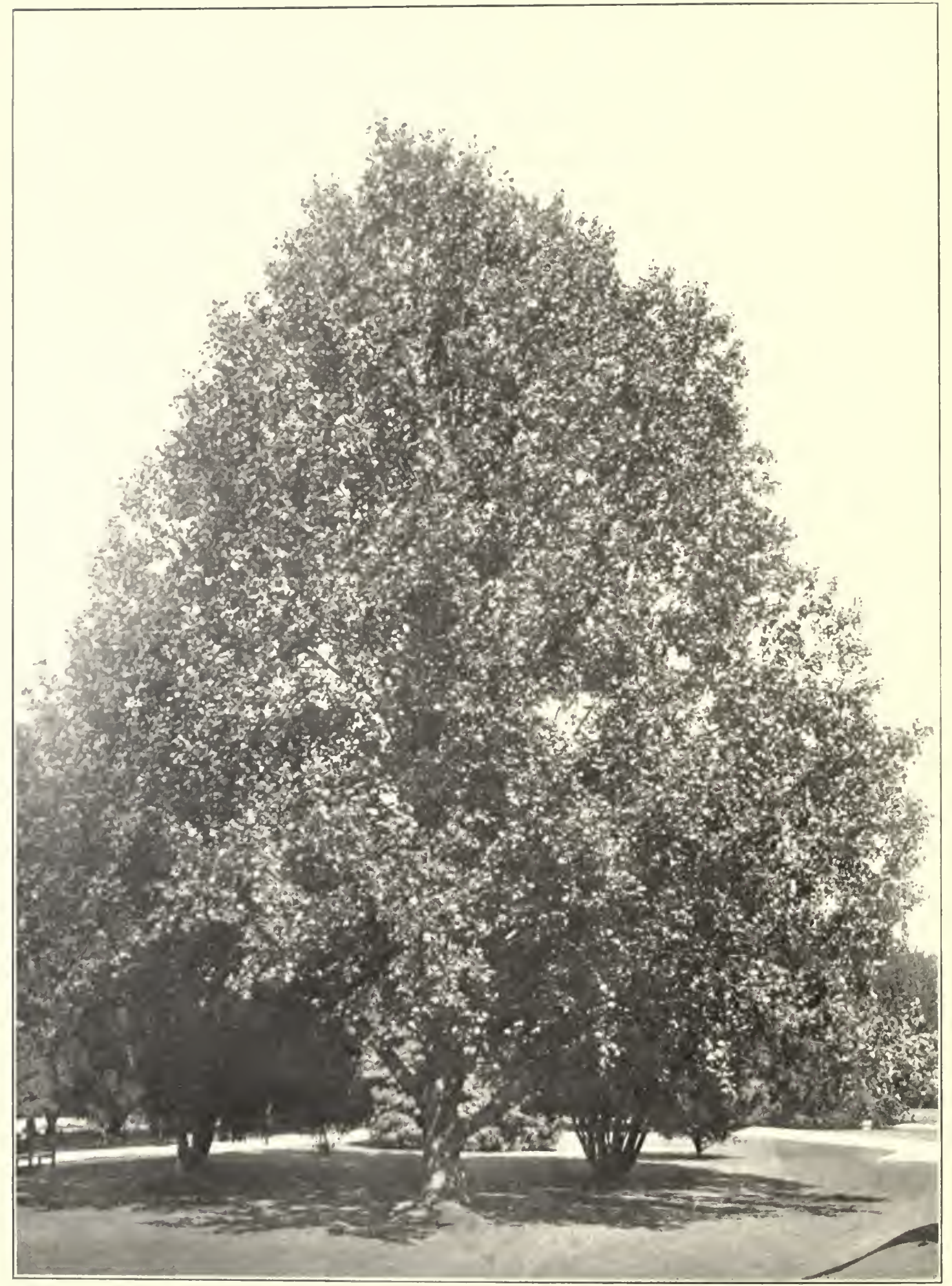

Plate 120. TULIP TREE, Sacramento.

"Here is one of my favorites now before me, a fine yellow poplar, quite straight, perhaps ninety feet high, and four feet thick at the butt. How strong, vital, enduring! How dumbly eloquent! What suggestions of imperturability and being, as against the human trait of mere seeming." 


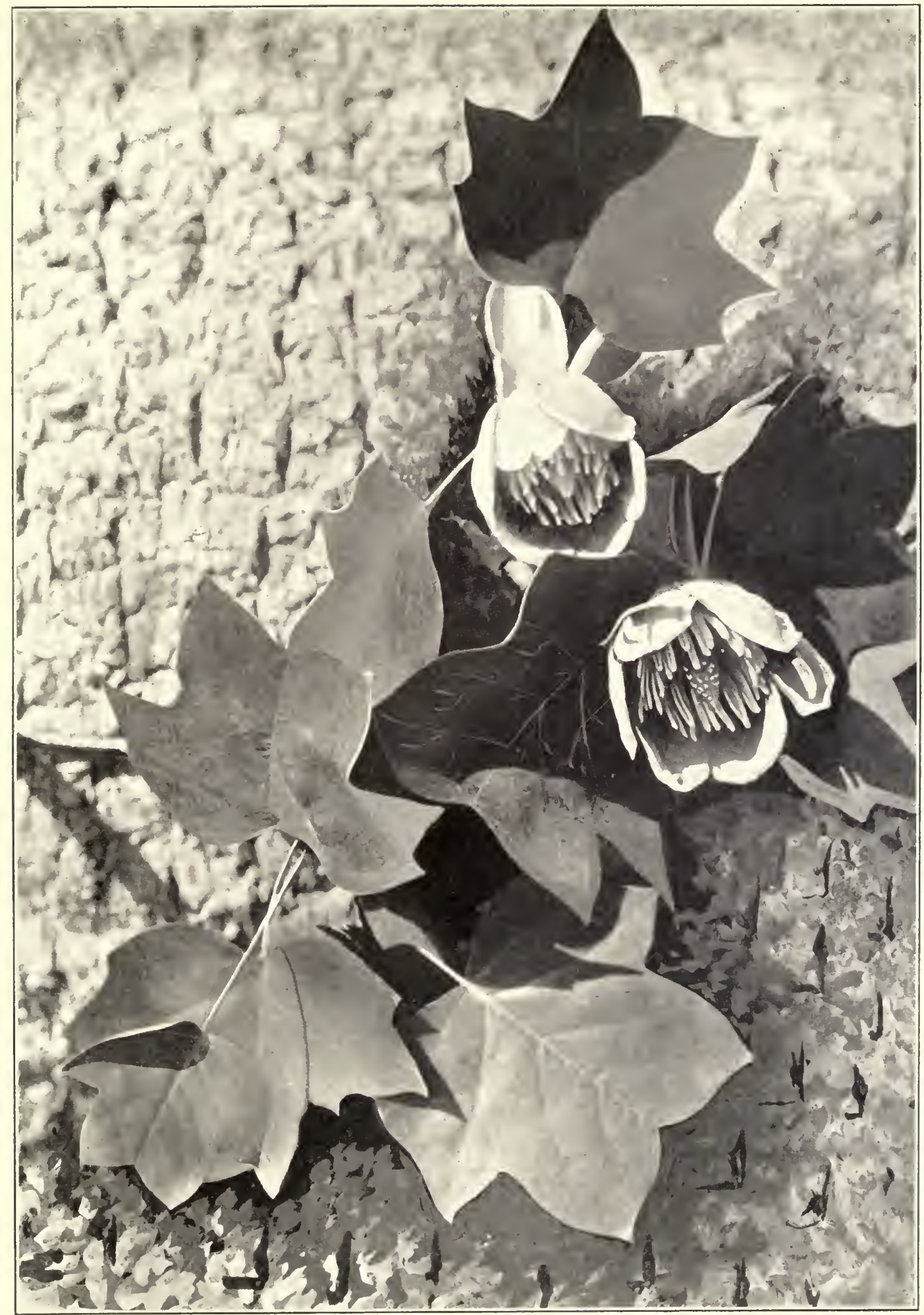

Plate 121. TULIP TREE BLOSSOM.

In remote period, the tulip tree flourished in Greenland together with redwood and other trees which were forced to the south during the Ice Age. 


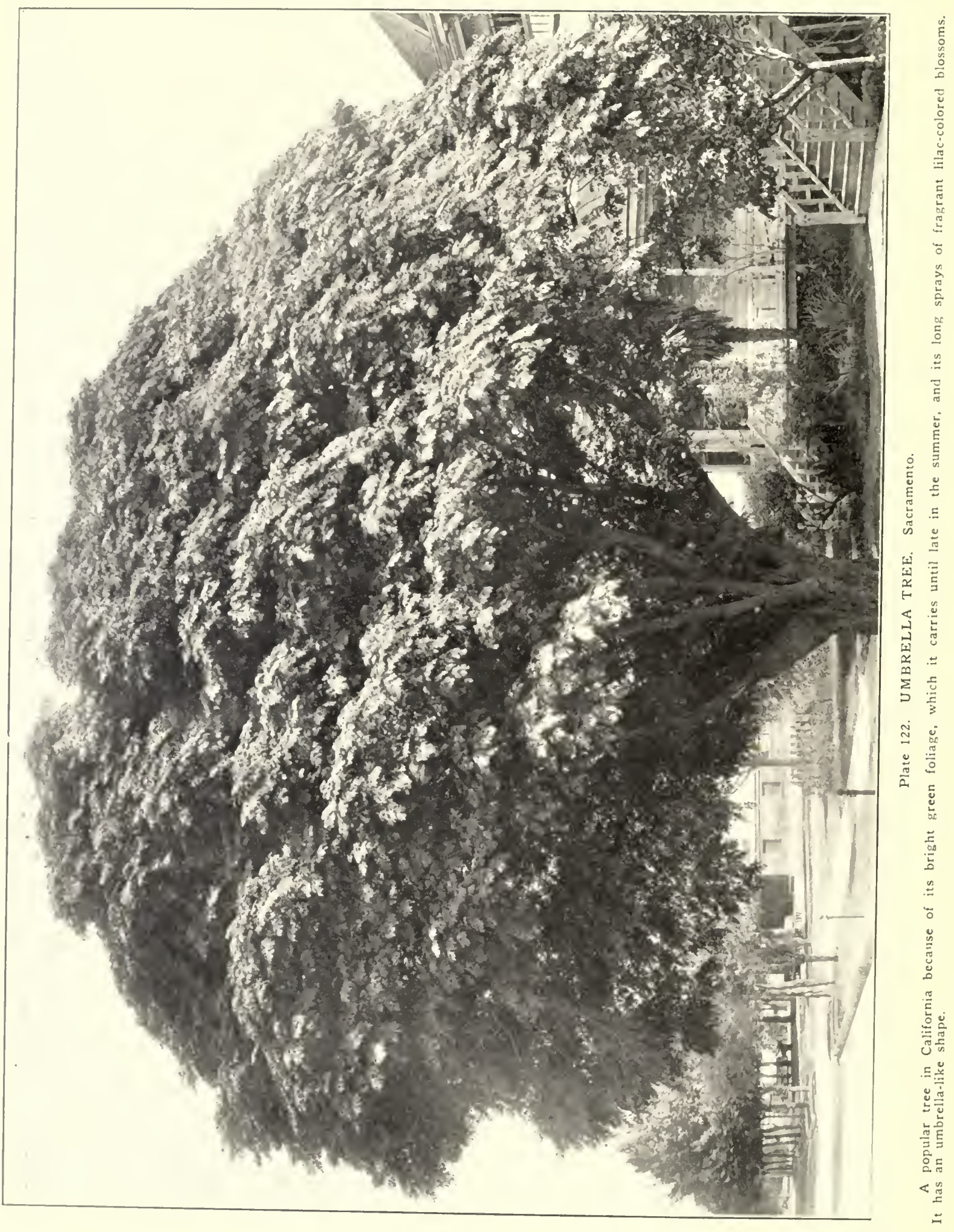




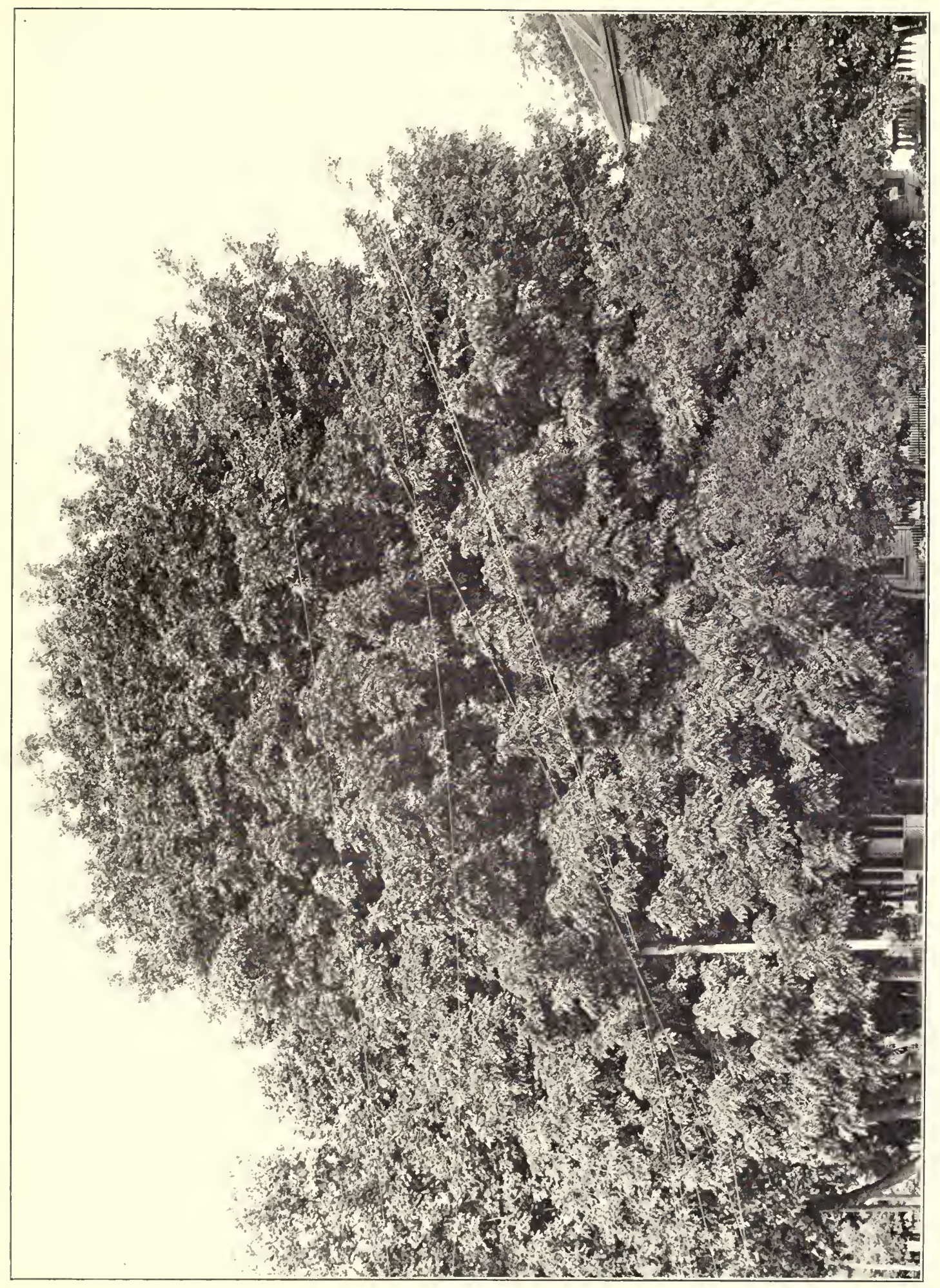$$
\text { 今 }
$$

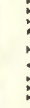

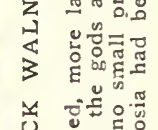$$
4 \text { 논 }
$$$$
\text { म }
$$

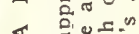$$
\text { ङ }
$$

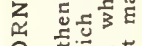$$
\text { 요 }
$$$$
\text { 出 }
$$$$
\text { 《 } \frac{5}{3}
$$

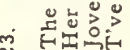

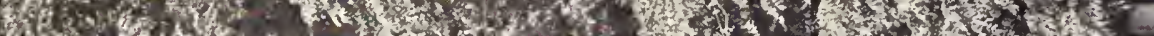

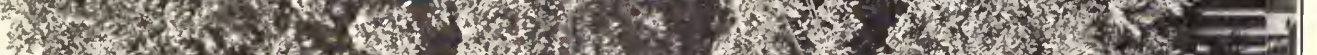

(x) L

W.

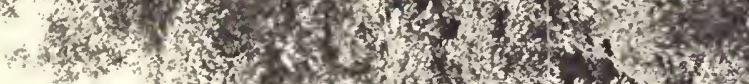

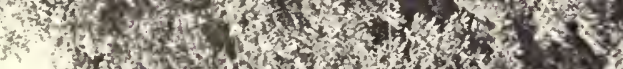

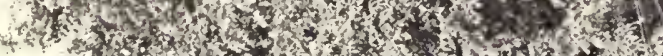

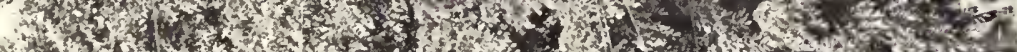

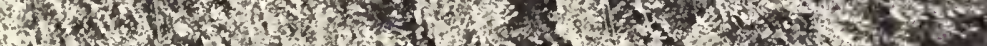

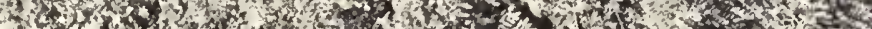

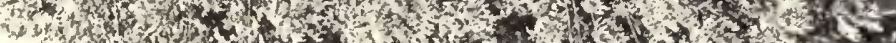

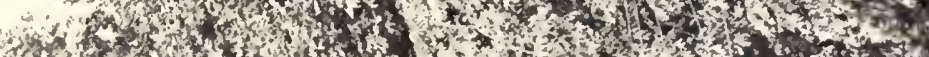

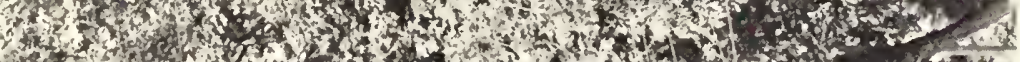

2.

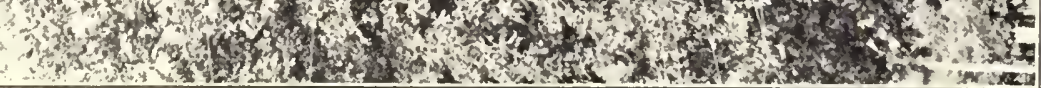

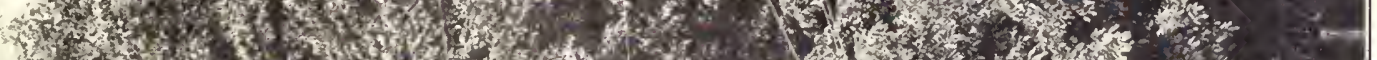

(1)

$$
\text { . }
$$




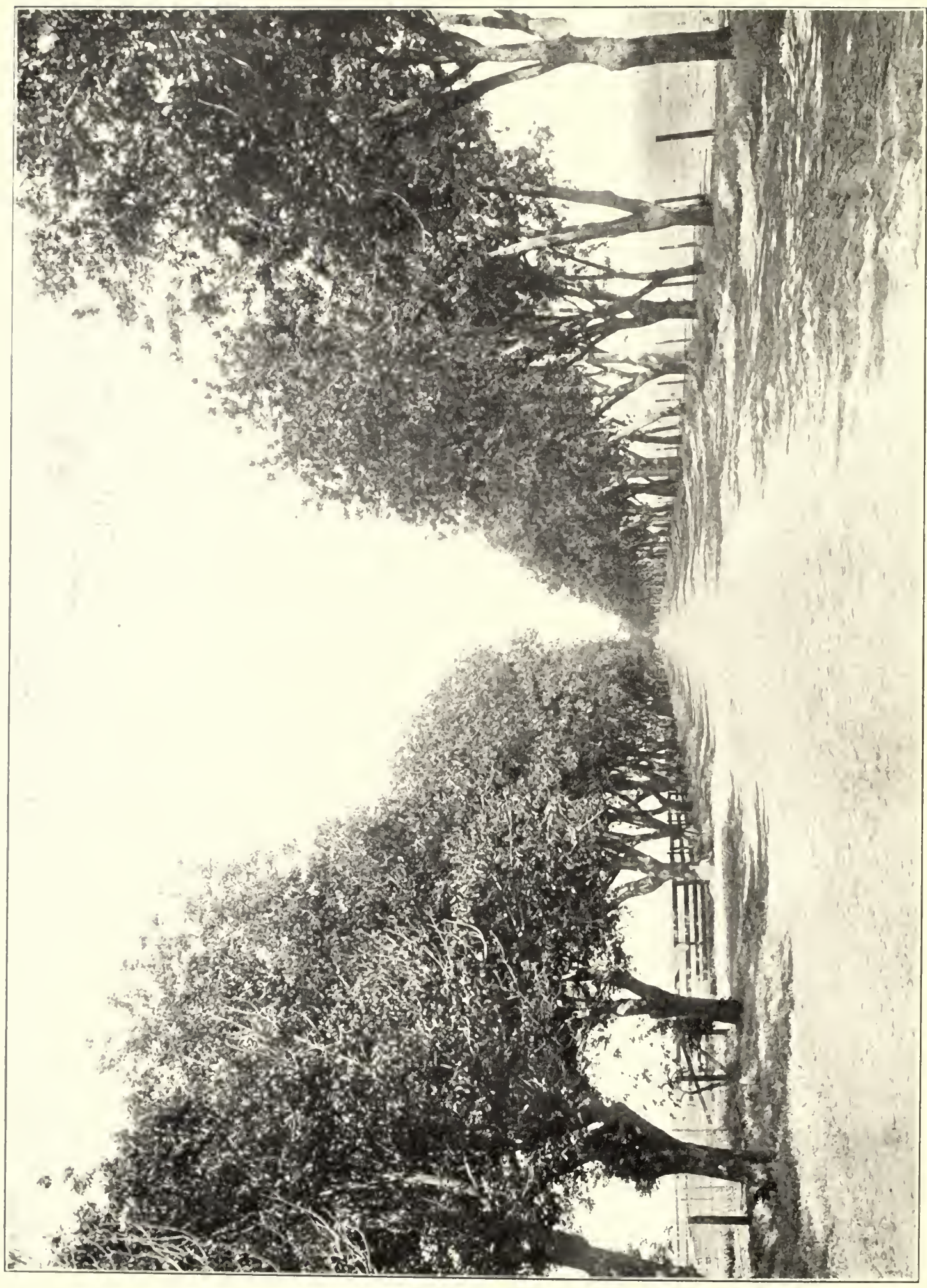

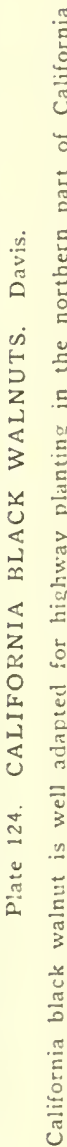




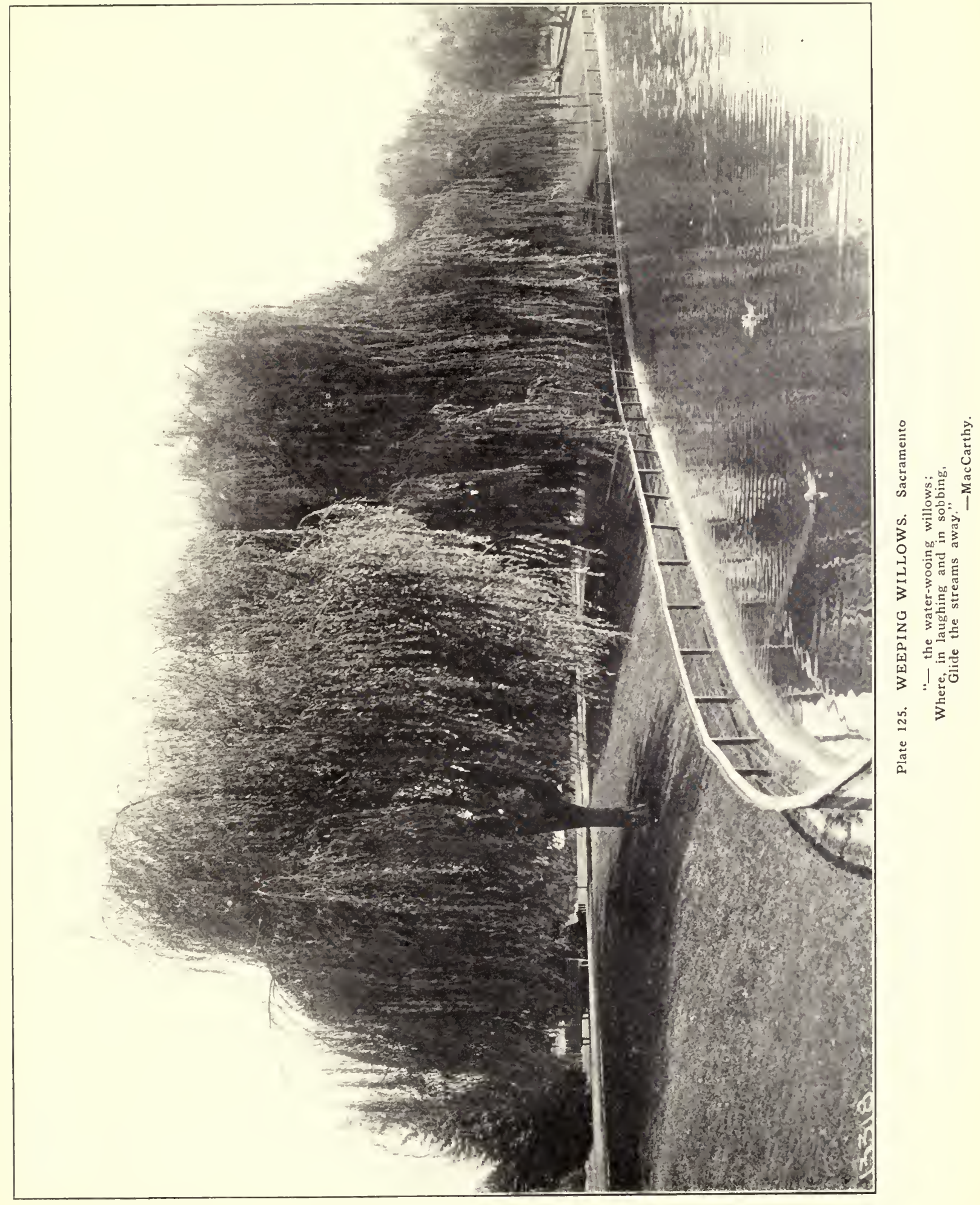




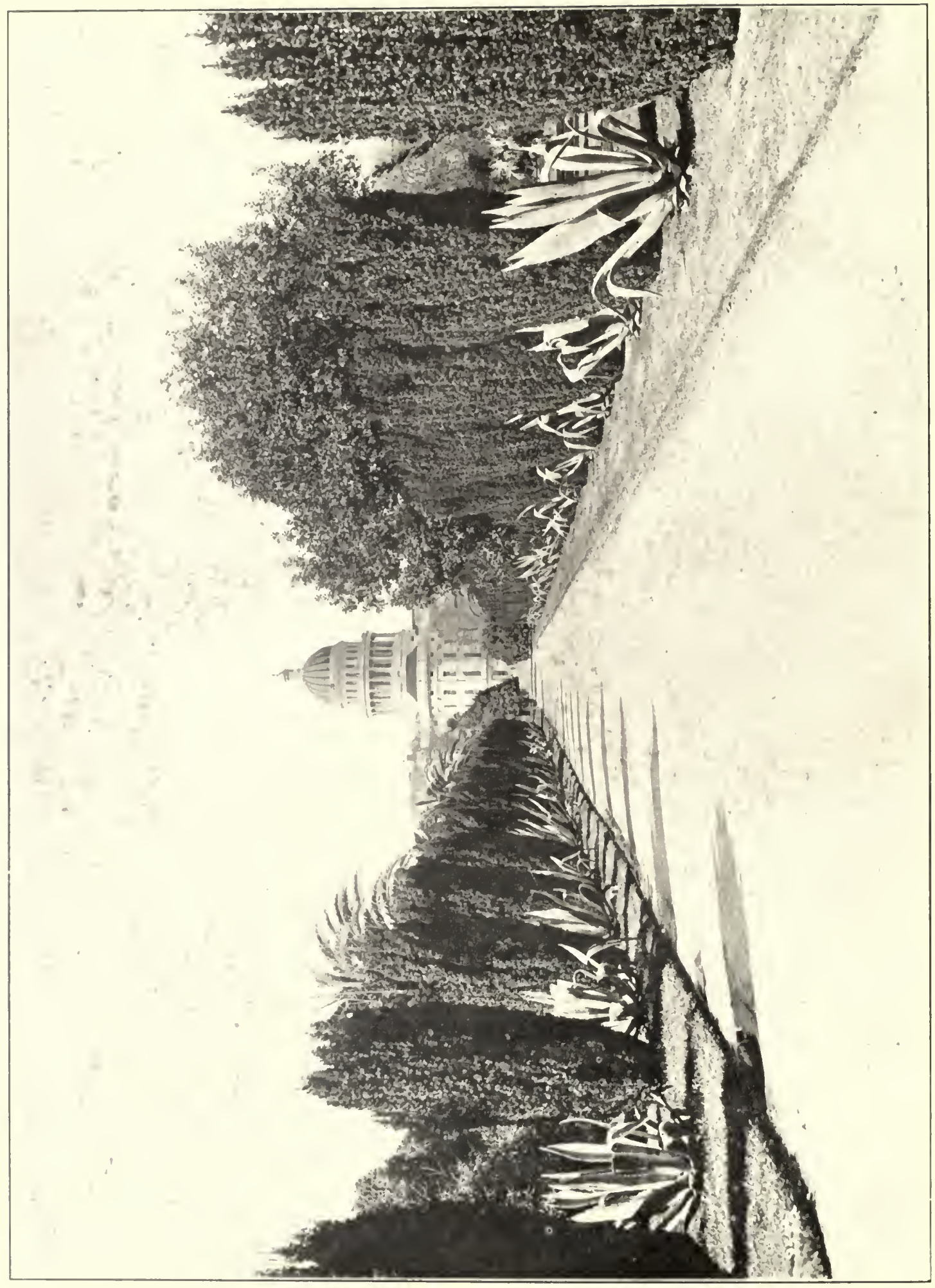




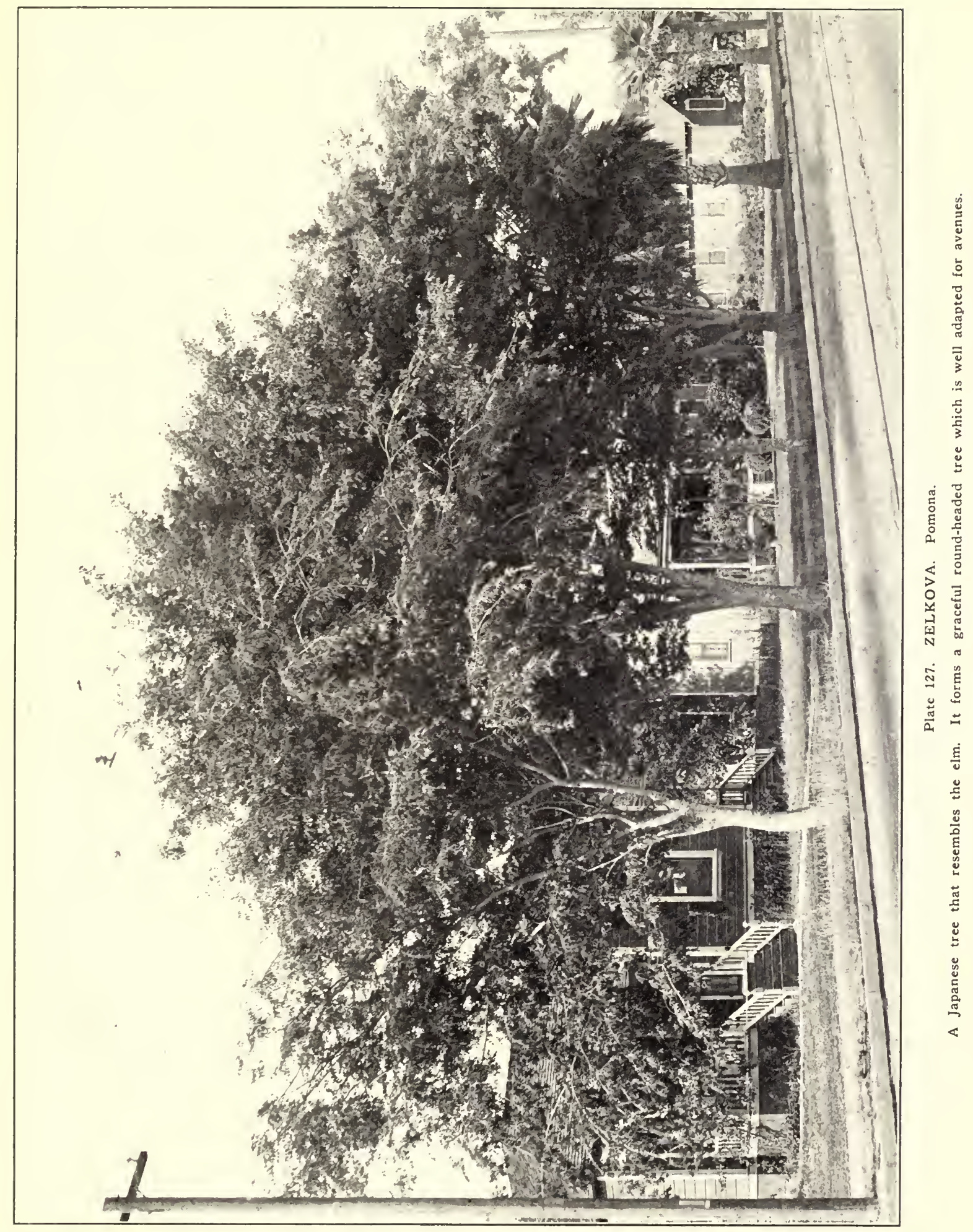




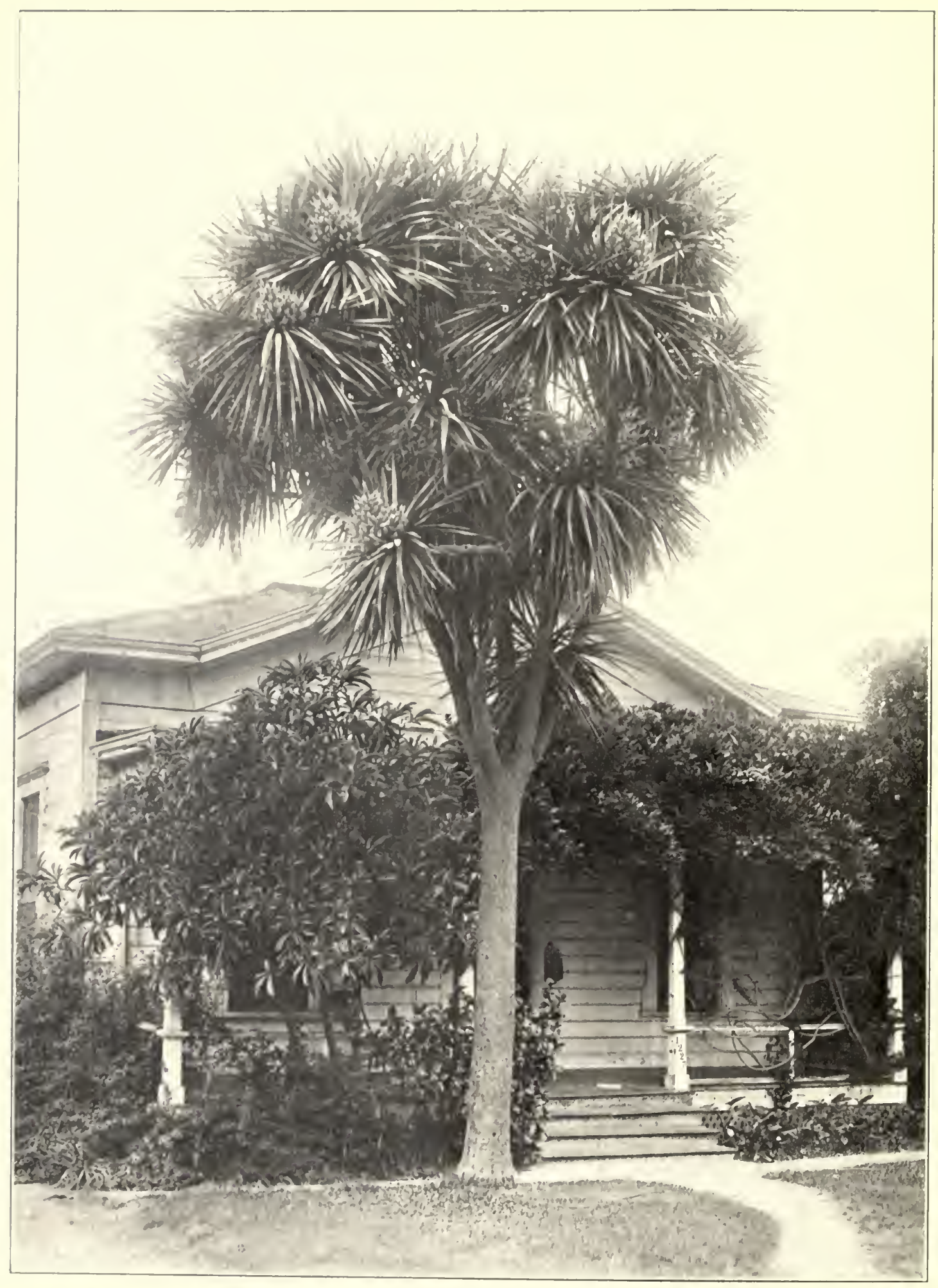

Plate 128. DRAGON TREE. Santa Barbara. A tree from the Canary Islands. Its dried juice is supposed to resemble dragon's blood. It is tropical looking
with sword-shaped leaves and large panicles of white flowers. 


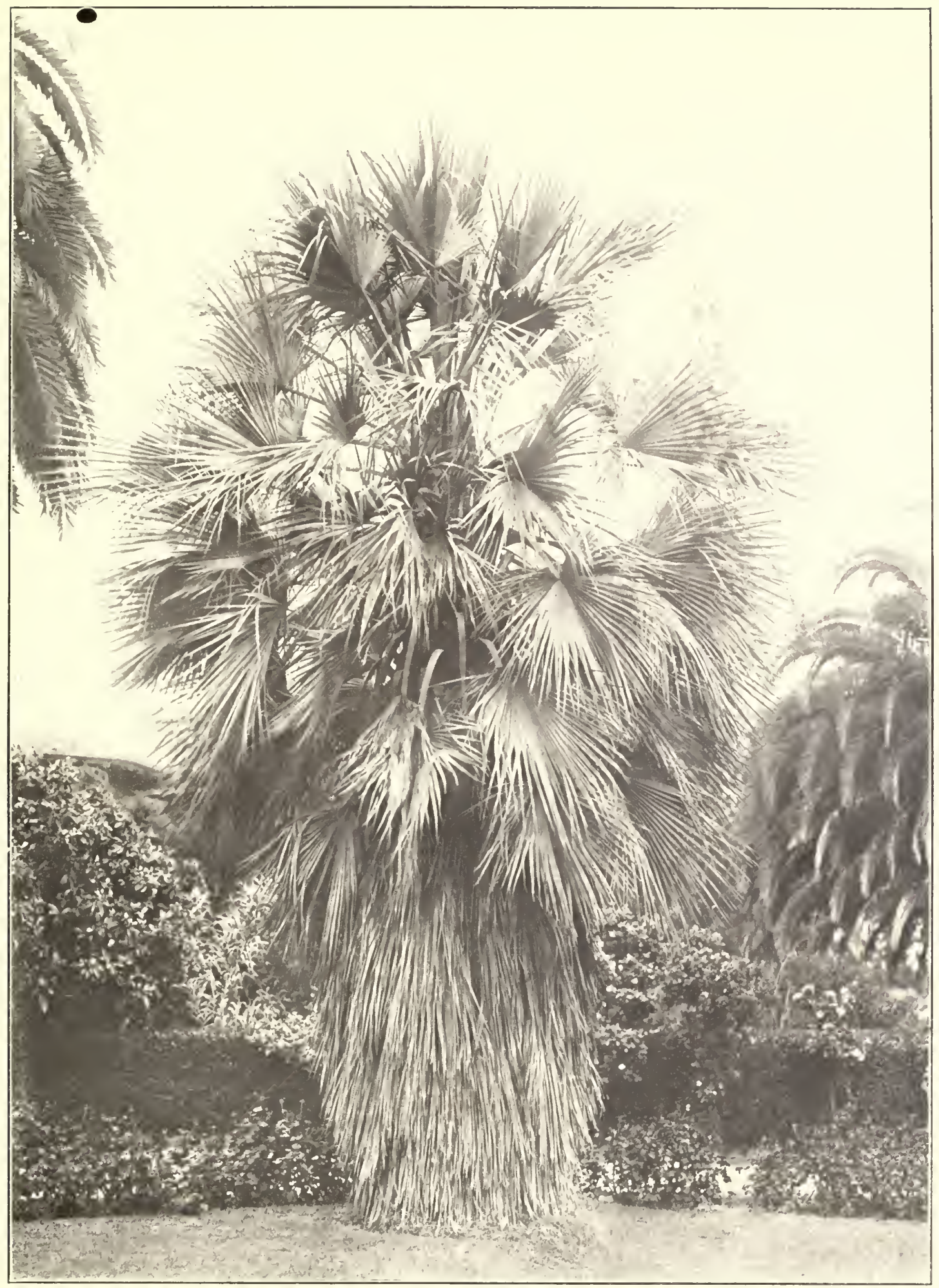

Plate 129. BLUE PALM. Pasadena.

A nalm from Lower California with a silvery blue hue and leaves armed with curving spines 


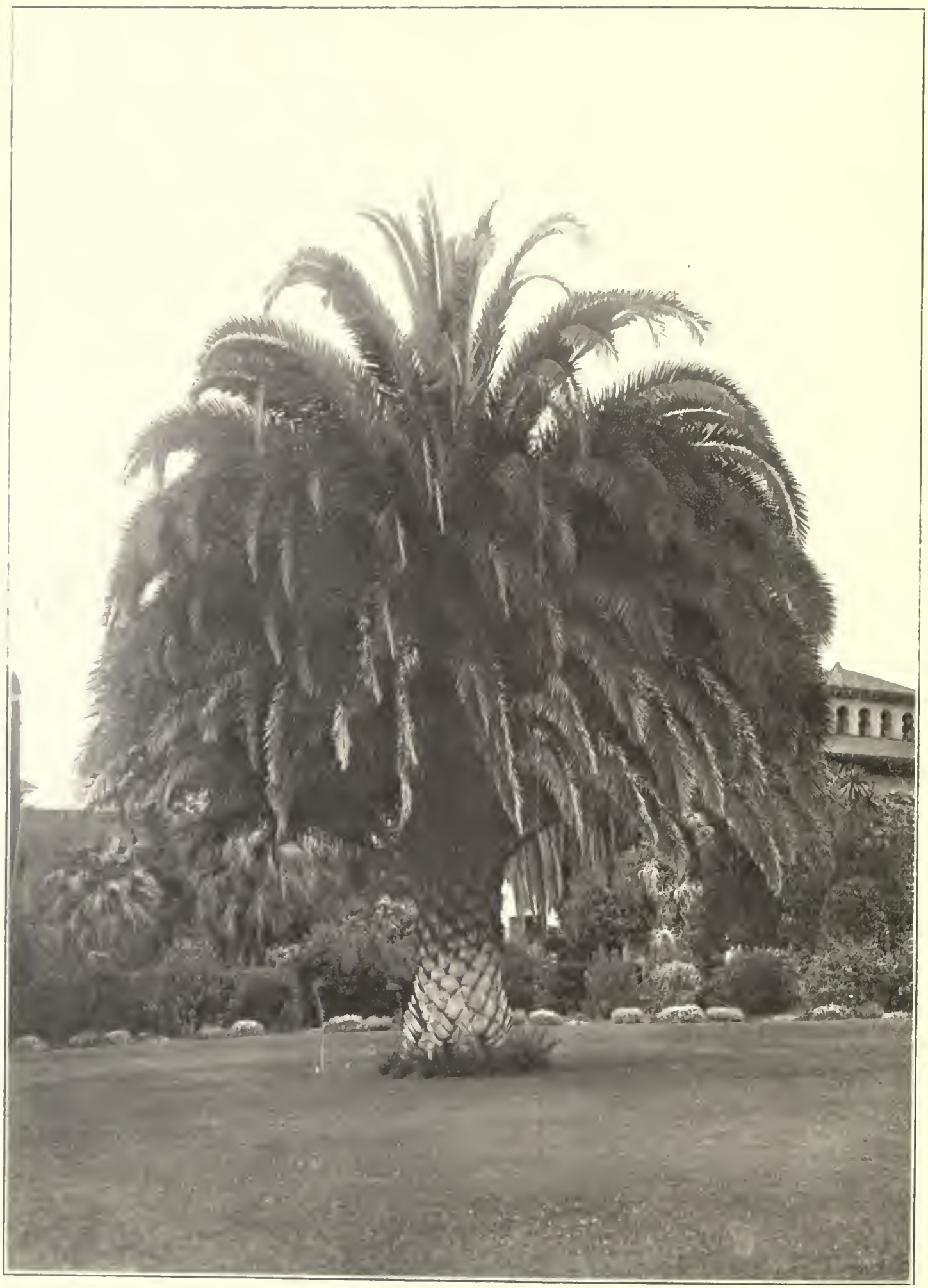

Plate 130. CANARY ISLAND PALM. Pasadena.

A balm introduced in:o Califorma from the Canary Islands. It is widely used to obtain attractive landscape effects. 


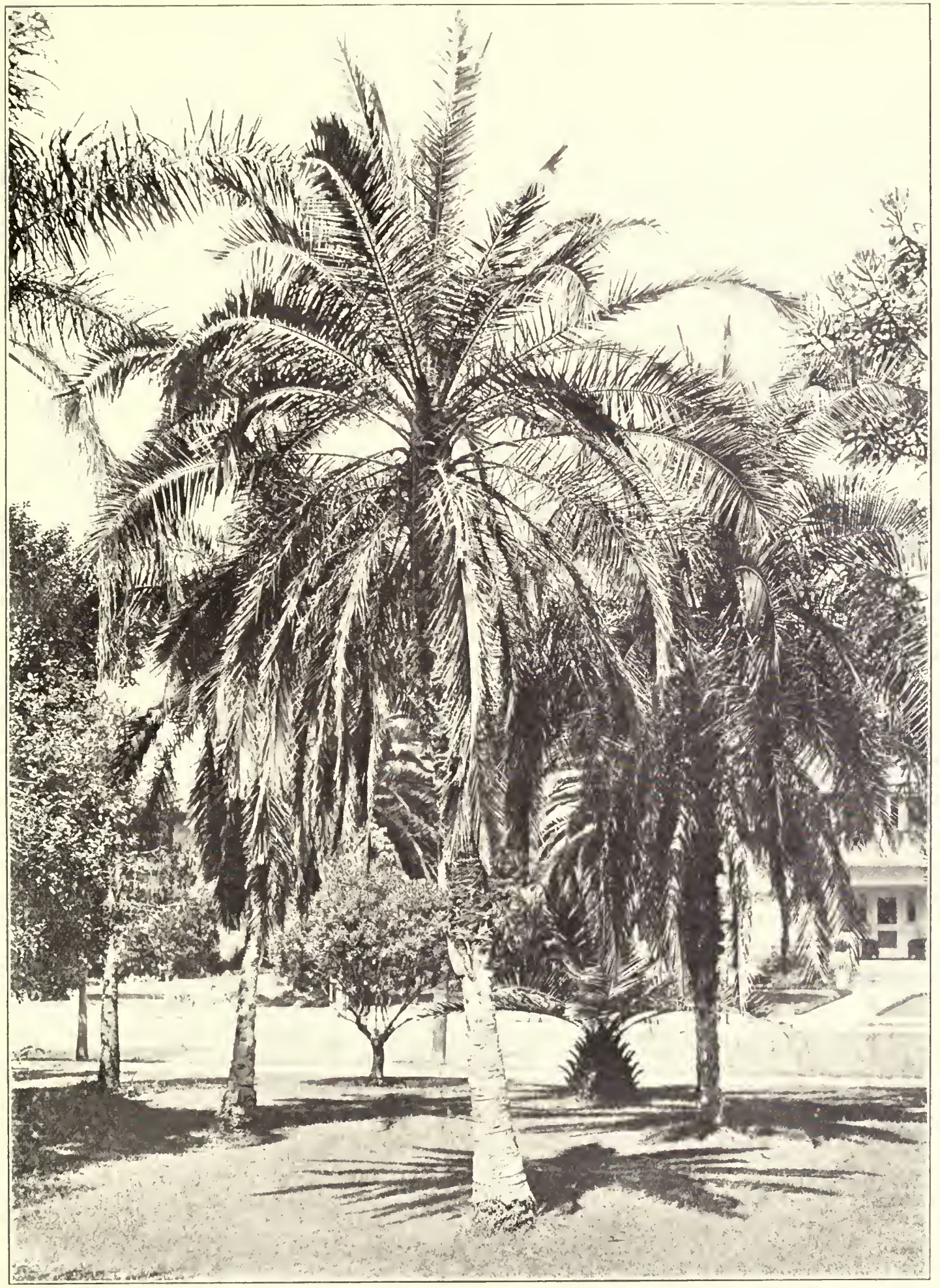

Plate 131. CAPE PALM. Los Angeles. 


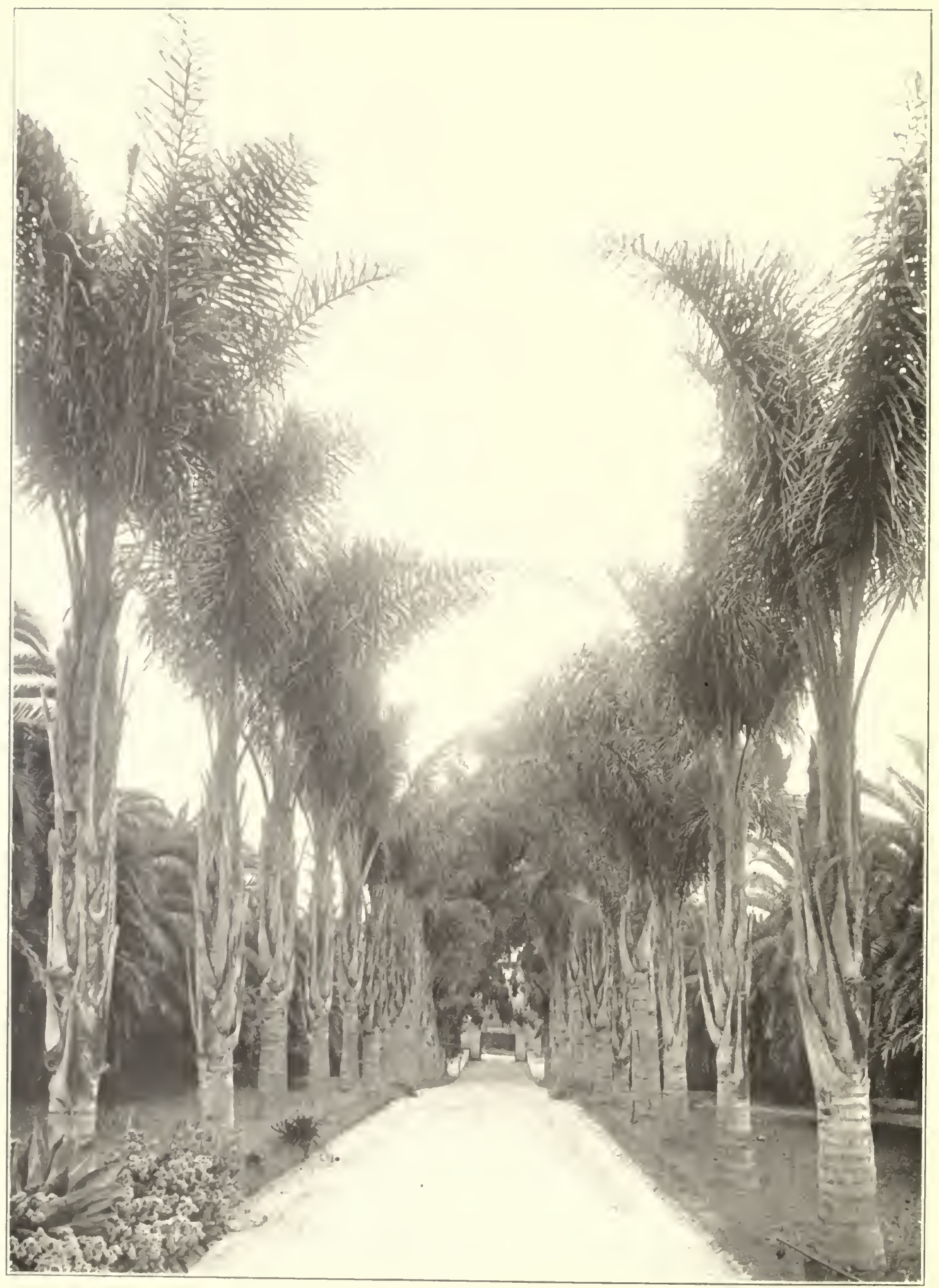

Plate 132, COCOS PALMS. Santa Barbara.

"The solemn palms were raneennyson.

Above, unwoo'd of summer wind." 


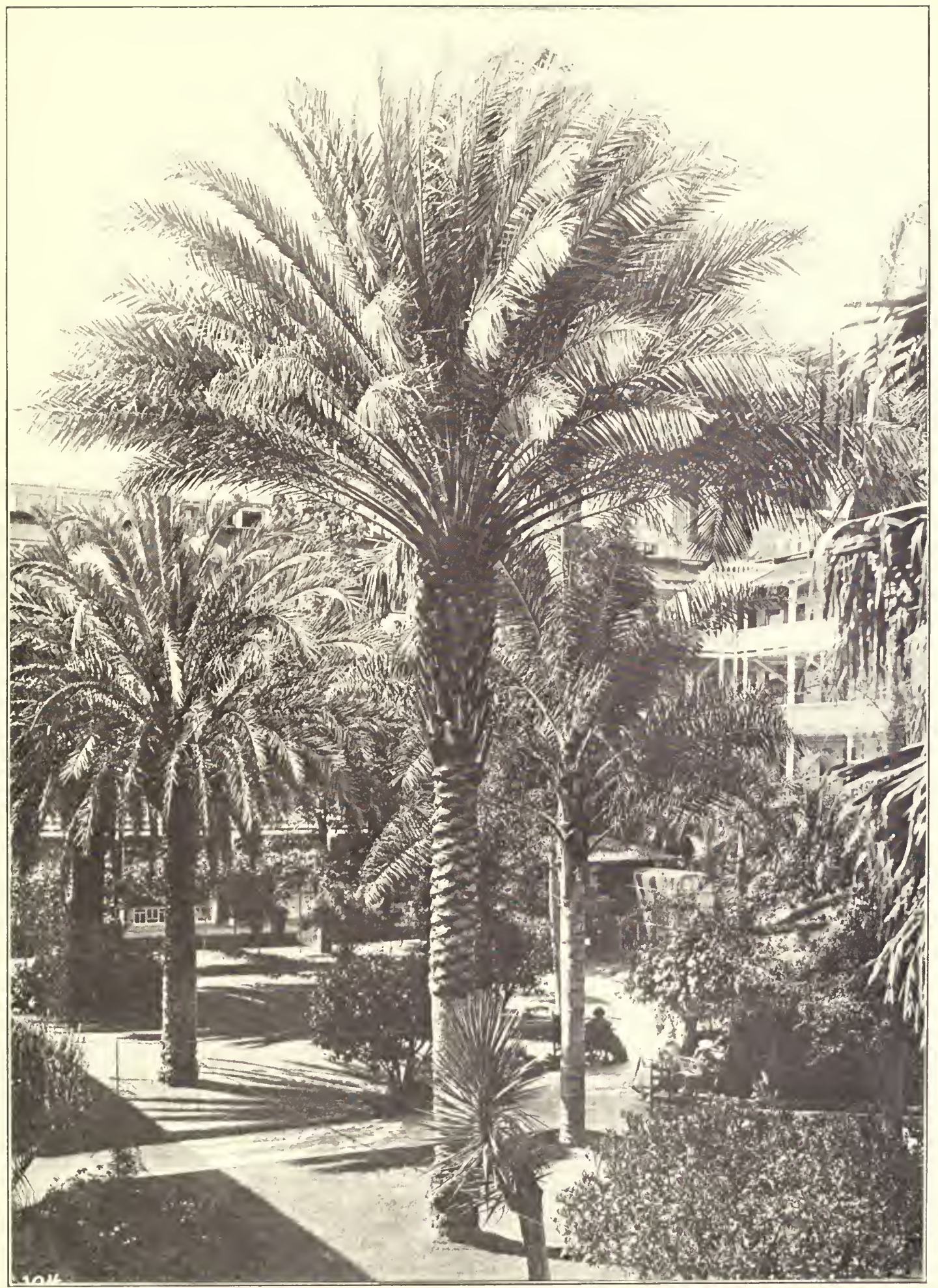

Plate 133. DATE PALMS. San Diego.

This palm was regarded as a mystic tree by both the Jews and the Arabs. It was renorted to rustle its leaves even when no wind was stirring, which was looked upon as a form of prophecy that their prophets could interpret. 


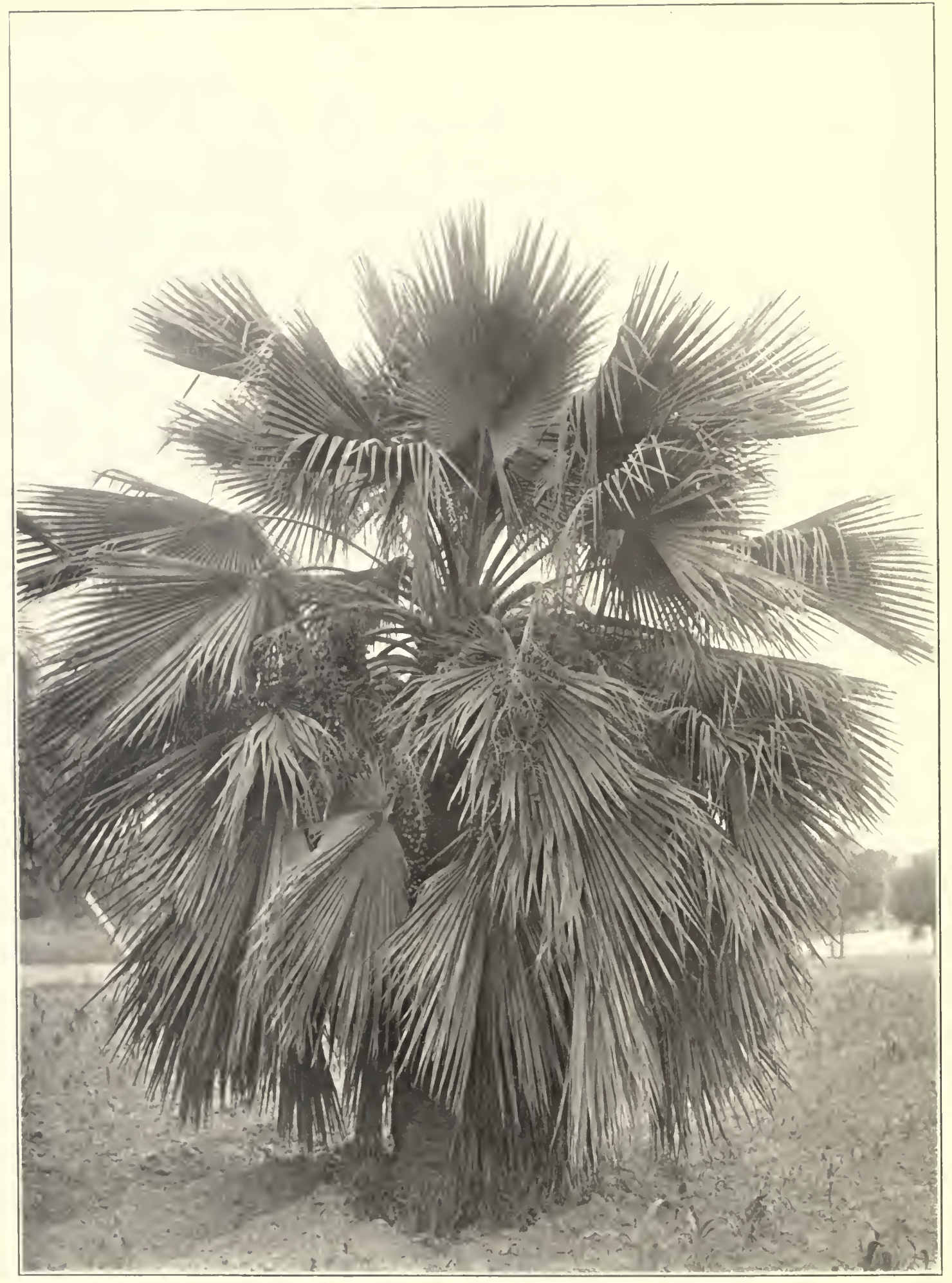

Plate 134. GUADALUPE PALM. Pasadena.

Found only in the wild state on Guadalupe Island, off the coast of Lower California. Under cultivation it is one of the most handsome of the fantleaved palms. 


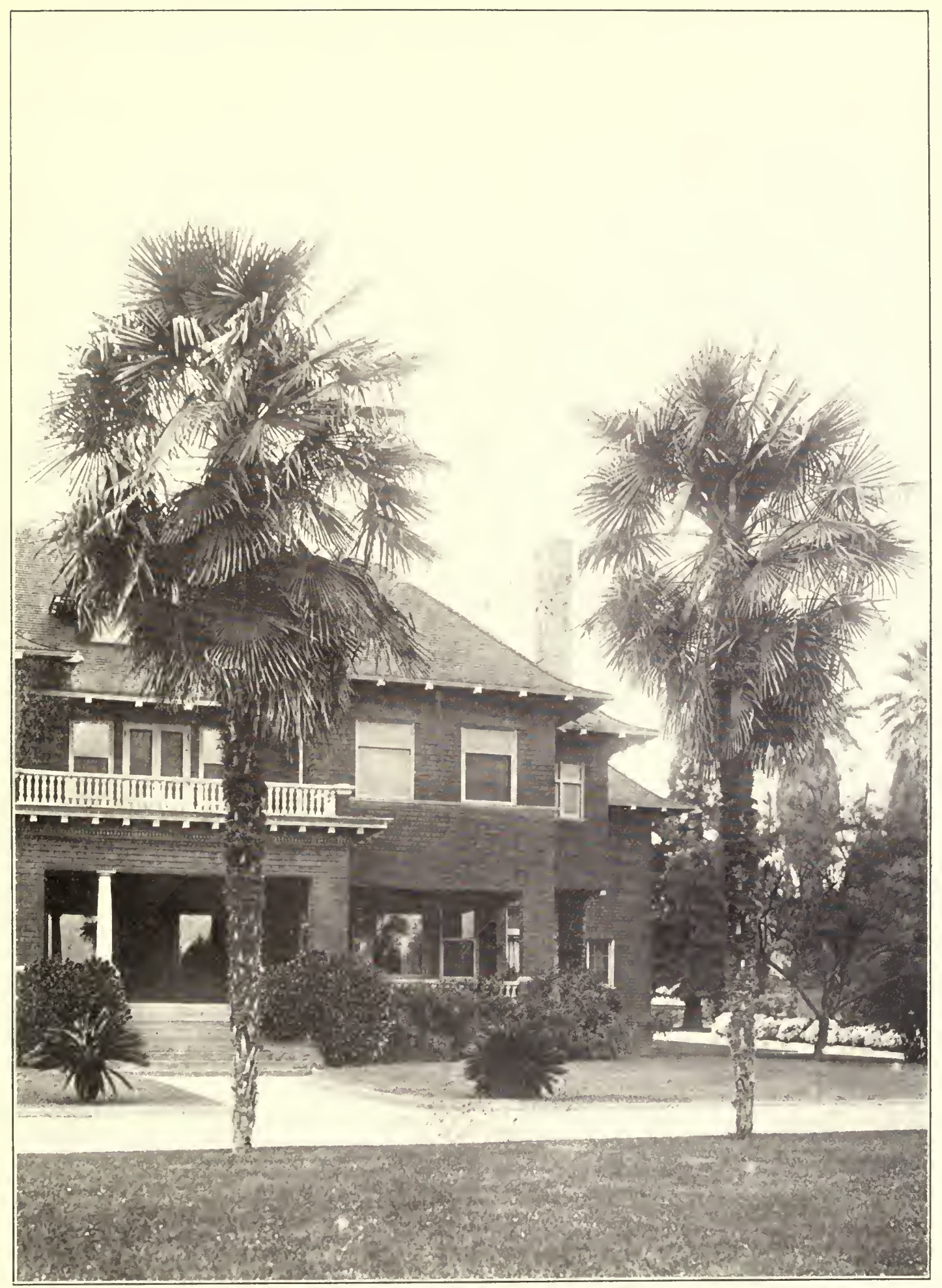

Plate 135. WINDMILL PALM. Pasadena.

An Asiatic fan palm which has a dense, black, hairy covering on its slender trunk. It is one of the hardiest palms known. 


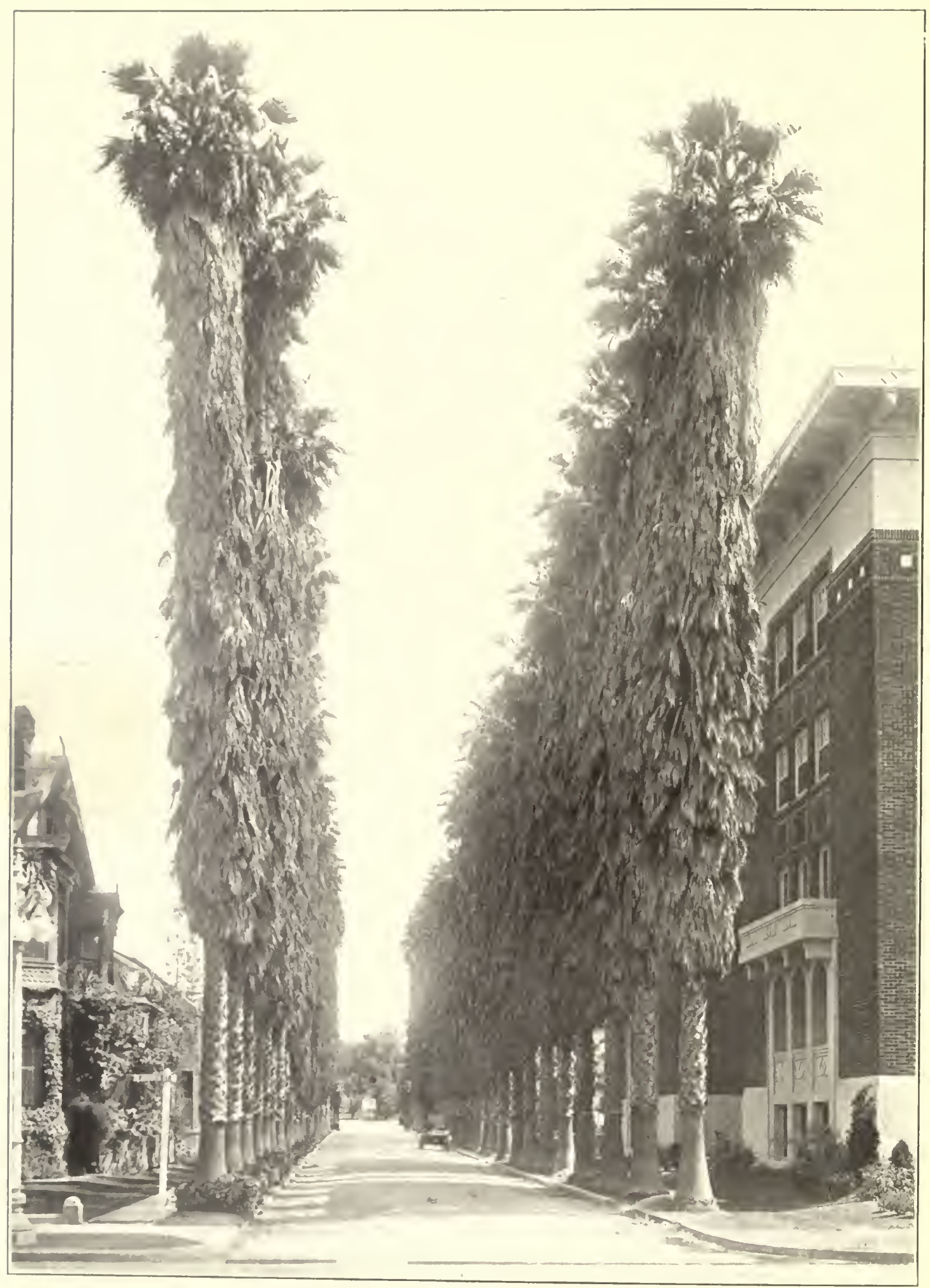

Plate 136. CALIFORNIA FAN PALM. Los Angeles.

'The marble minarets that begem

Caro's citadel-cliadem

Are no: so light as his slender stem.

Ile lifts his leaves in the sumbeam's glance

As the Almehs lift their arms in dance. 


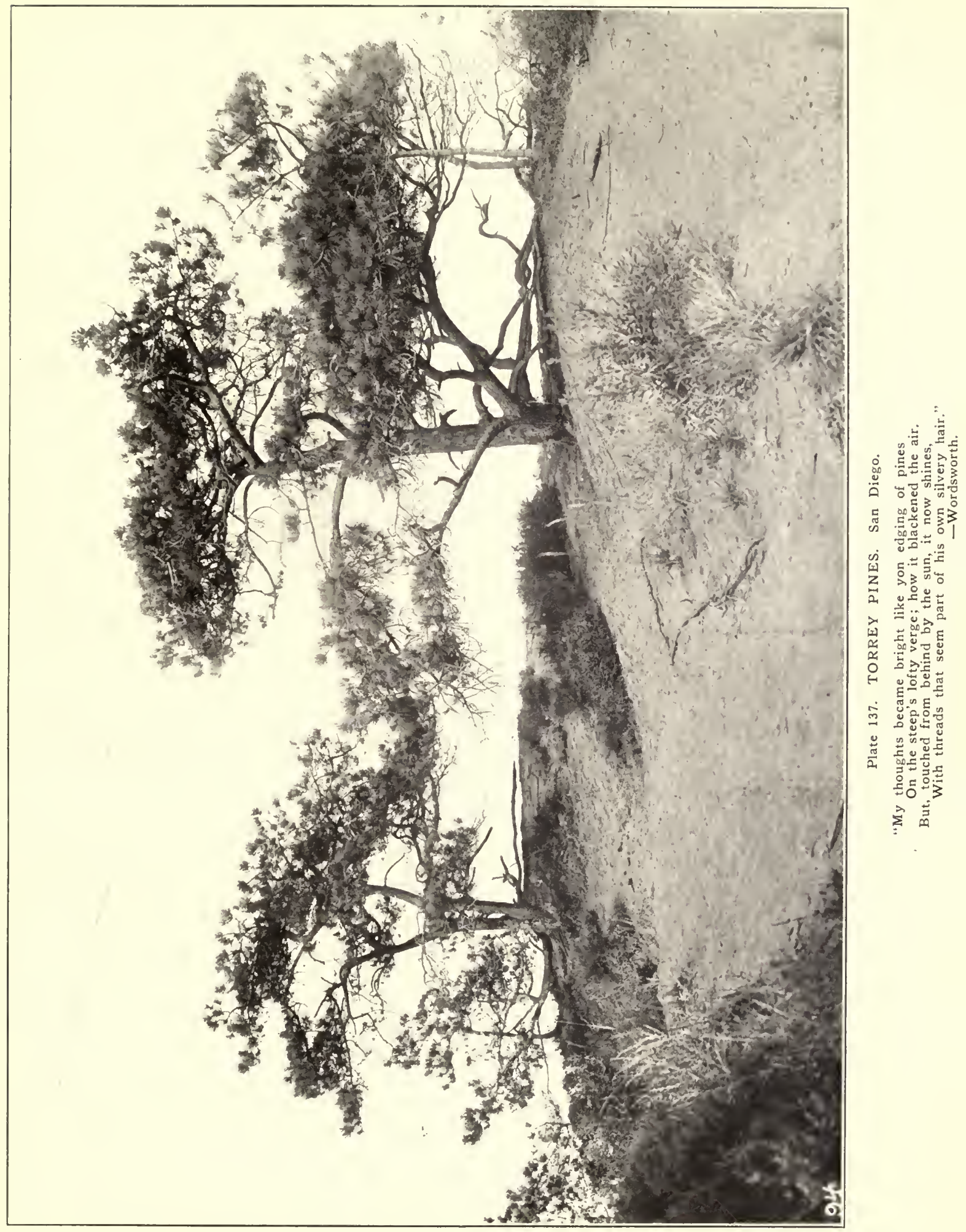




\section{INDEX}

AC:1Clas- Paye

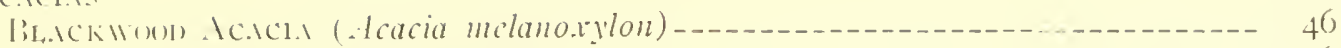

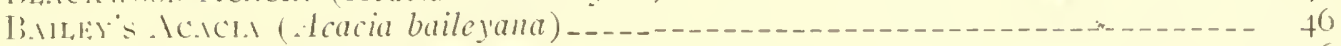

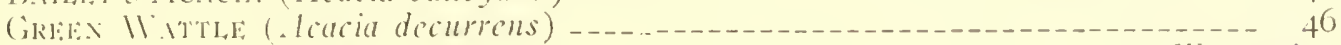

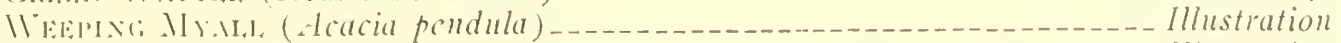

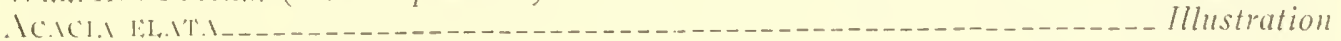

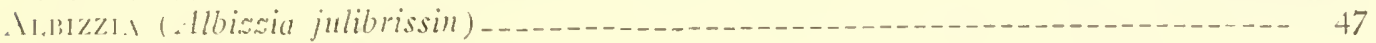

MR.MTC.MRTIS-

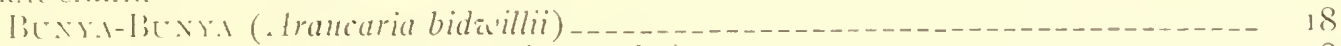

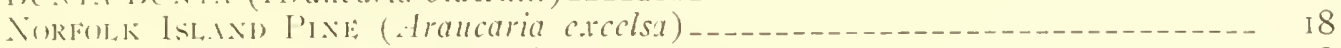

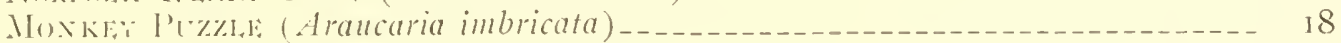

ARIORTITA:-

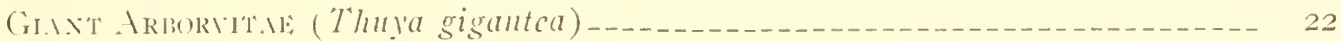

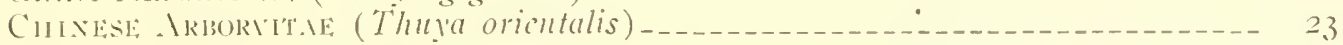

ISHIS-

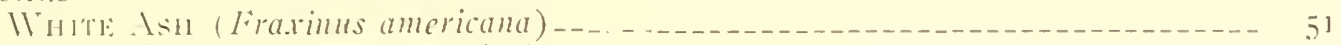

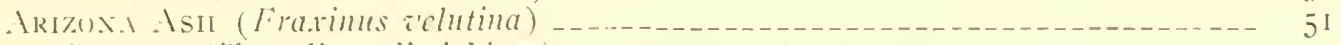

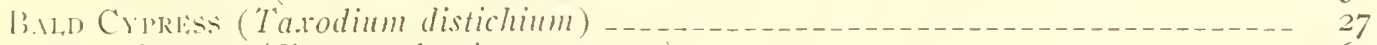

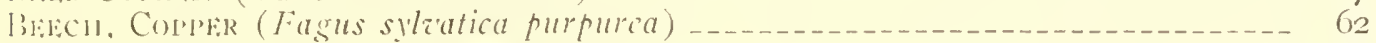

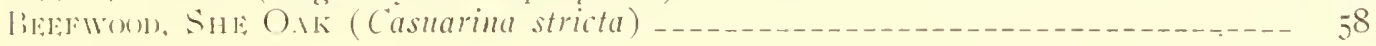

limenlis:-

Wuits: linen (Betula alba)

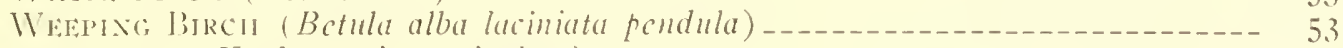

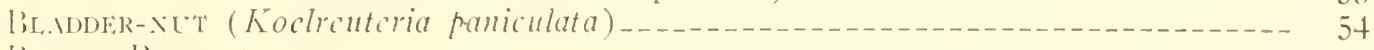

bitTLE: BRESIIS-

BoTTh: liRTSH (Callistemon lancolatus)

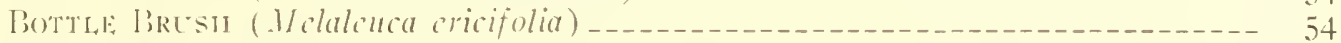

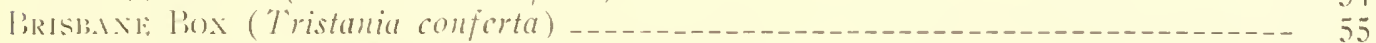

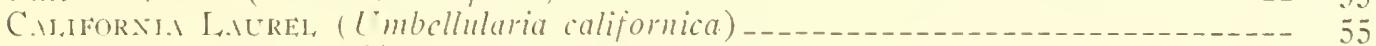

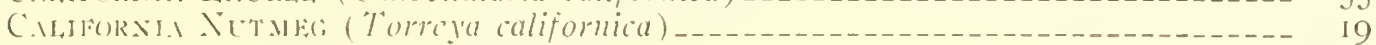

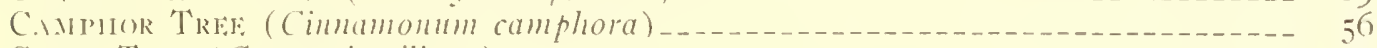

C.Iros Tres: (Ceratonia siliqua) _.

C.ITILIP.X (Catalpa speciosa) -

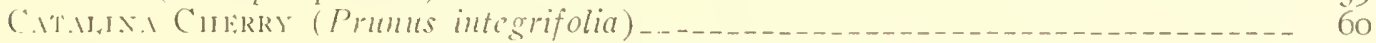

Cid.uks-

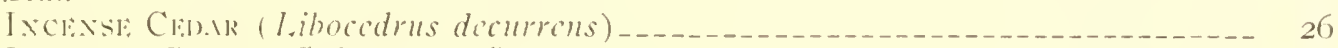

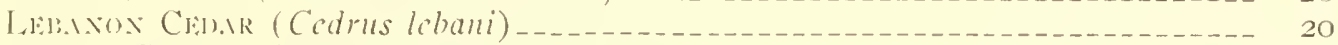

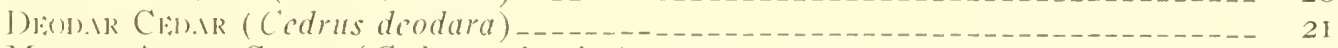

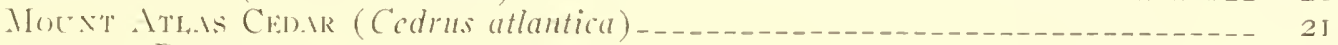

CIIRISTMAS BFRRY-

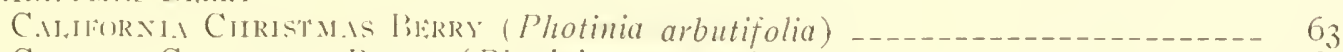

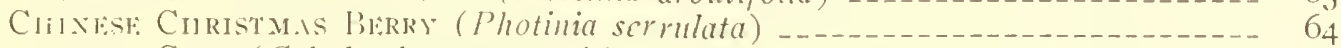

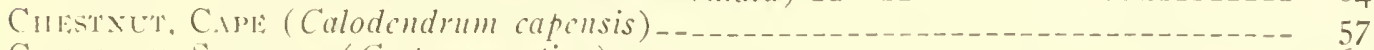

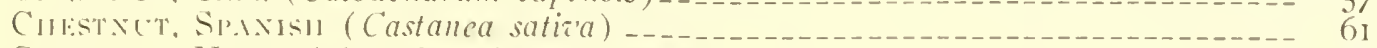

CuFire'T, Hors: (Acsculus hippocastanum)

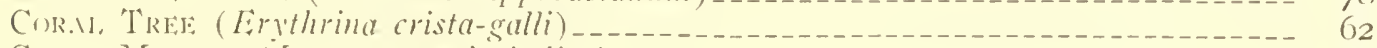

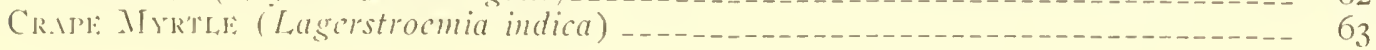




\section{INDEX-Continued}

mitise

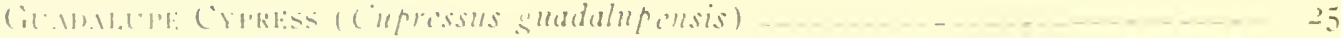

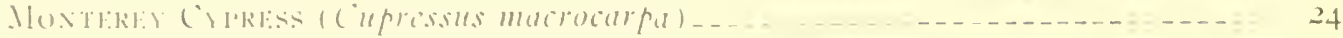

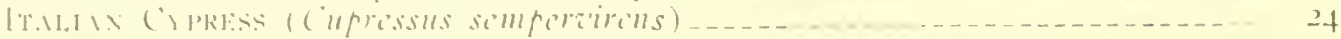

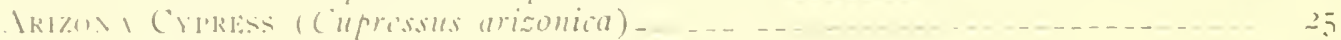

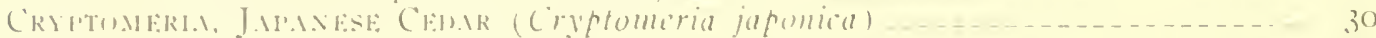

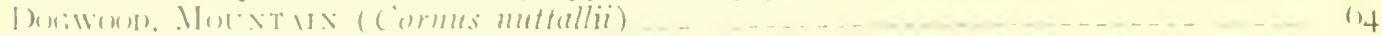

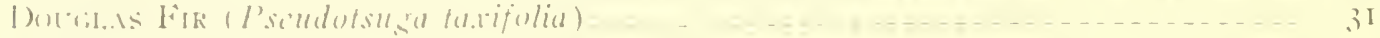

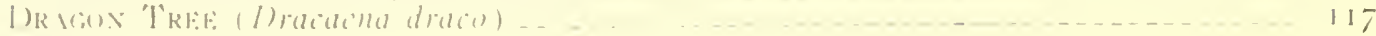

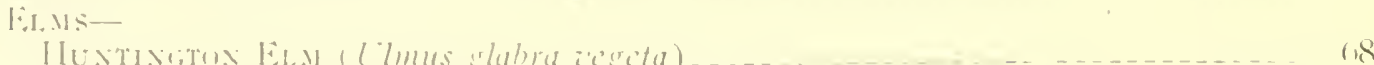

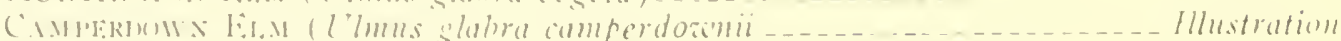

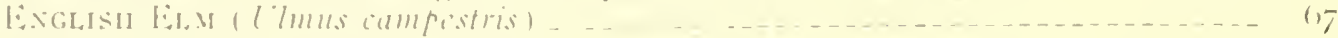

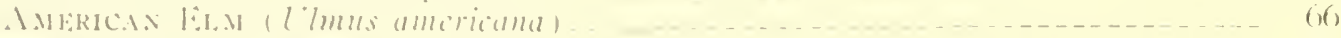

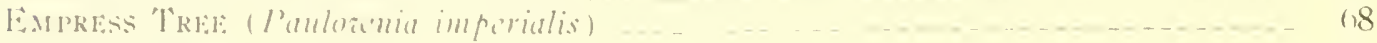

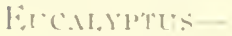

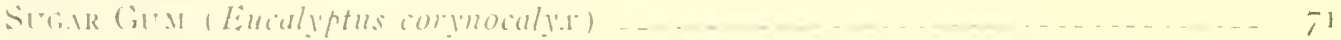

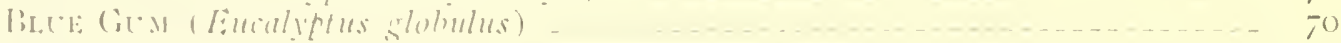

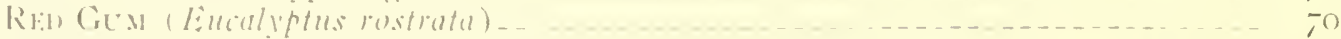

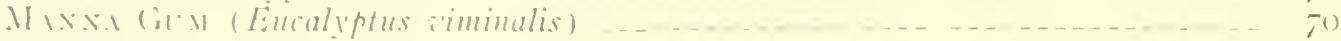

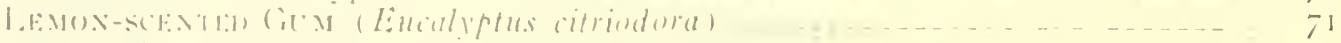

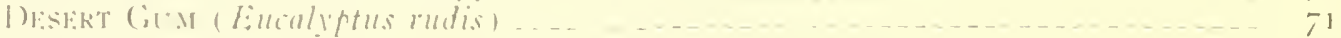

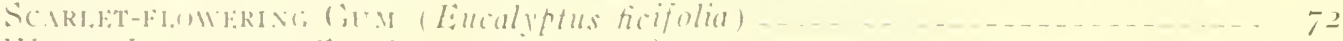

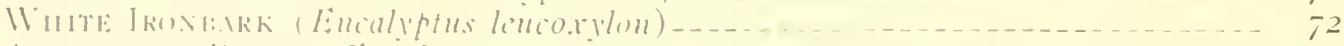

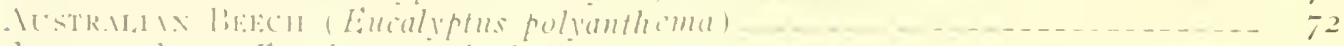

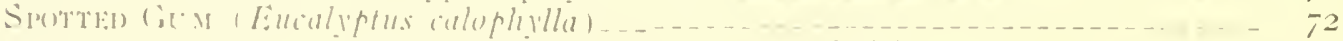

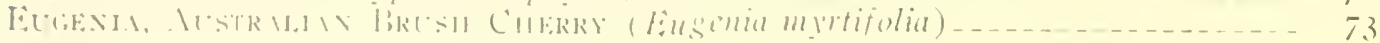

Iiks-

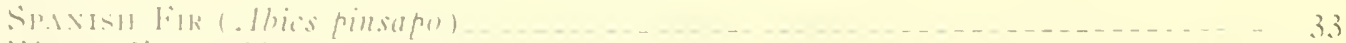

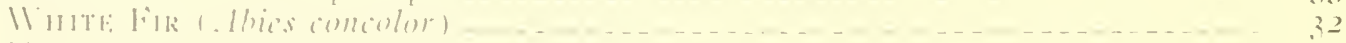

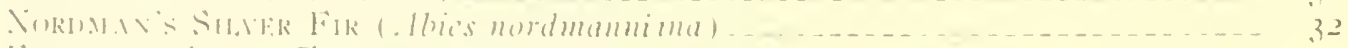

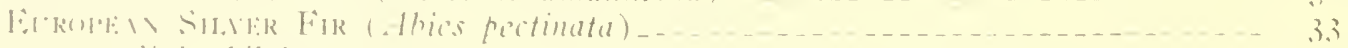

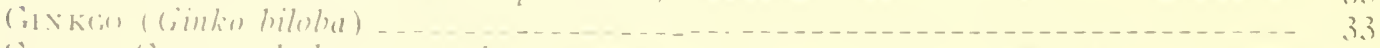

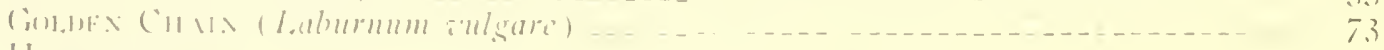

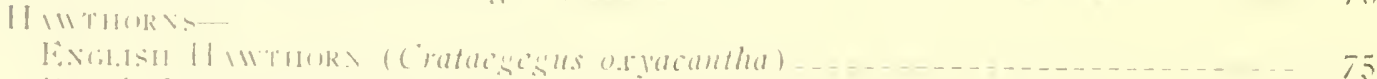

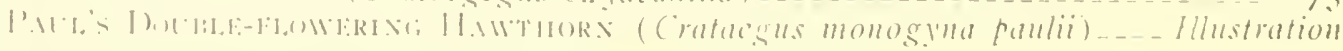

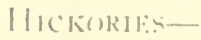

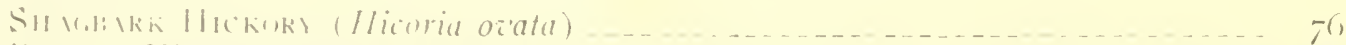

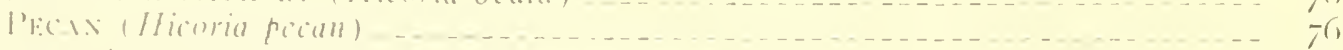

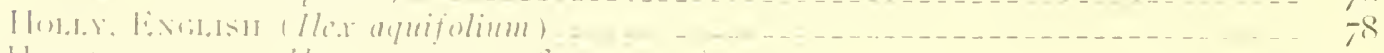

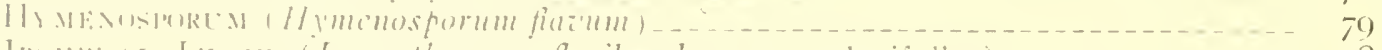

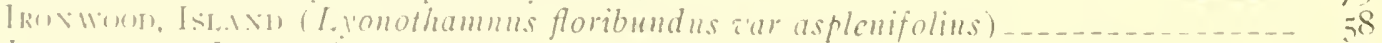

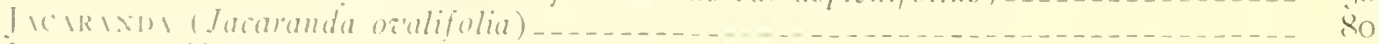

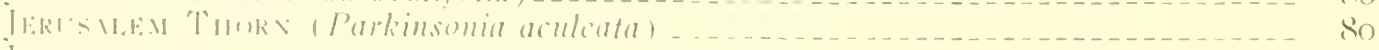

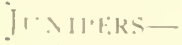

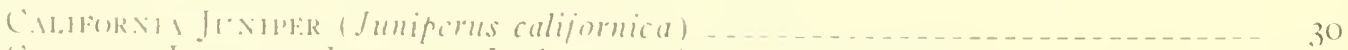

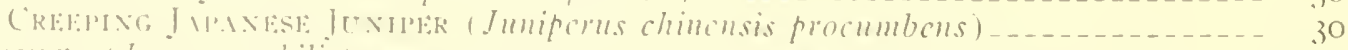

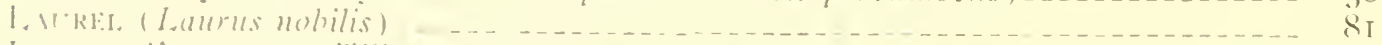

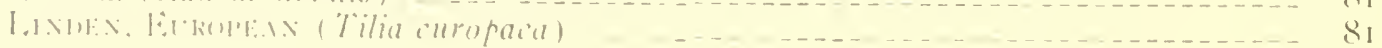




\section{INDEX - Continued}

Pagc

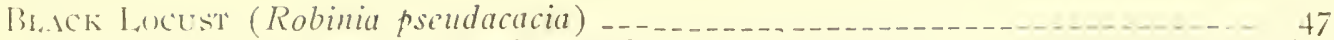

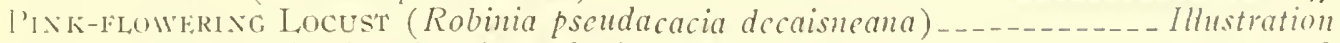

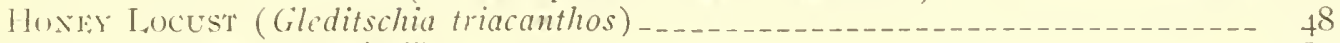

M.AnRoxi (Arbutus meñicsii) _.

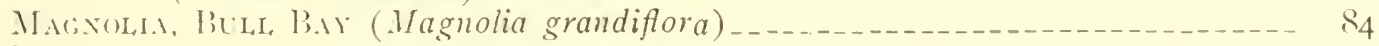

M.MPL, ES-

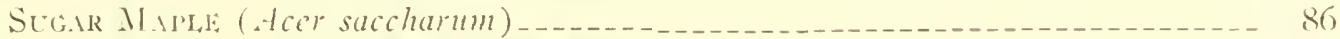

BIG-LEAF MAPLI: ( Icer macrophyllum) _.

NORWAY MALLE (Acer platanoides) _._.

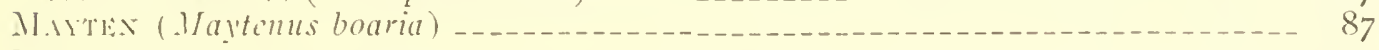

MIIBERRIES-
RIII) JULBLRR ( Jortls rubra)

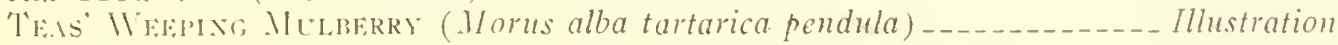

( ). $1 \mathrm{~K}:-$

C.MFURNIA LIVE O.\K (Quercus agrifolia)

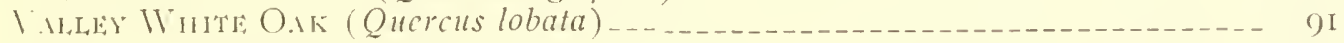

Corк O.ıк (Queris suber) _.

lick O.ık (Quercus macrocarpa)

() I. E.III:R (. Verium oleander)

Osmi: (Oléa éuropaéa )

Orcuin Trke, (Bauhinia purpurea) _.

I'irion). TRFi: (Sophora japonica pendula) $\ldots \ldots \ldots \ldots$

l'.12, MS -

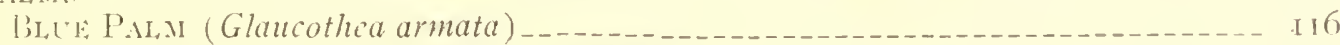

C.INARI ISLAND PALM (Phoenit canariensis)

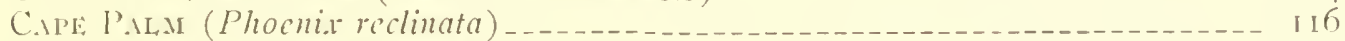

Cocos P.ı. (Cocos botryophora )

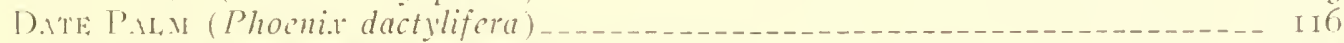

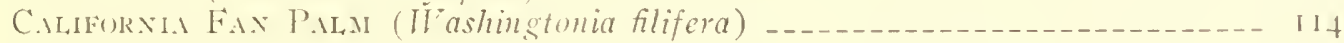

Civandepl: P.un (Erythed edulis)

Prino I'Ala (Cocos aitstralis)

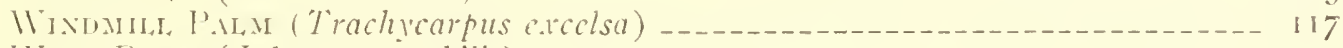

Mixi P'in.M (Jubaea spictabilis) _.

T'EPPIER 'TRELS-

C.ILIFORNIA I'EPIER TRFF, (Schimis molle) -

J'R.IZILI.IX PEPPI:R 'TREF, (Schinus terebinthifolius)

PINFS-

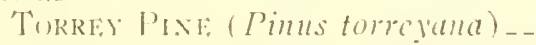

C.INIRI [SI.AND PINF, (Pinus canariensis)

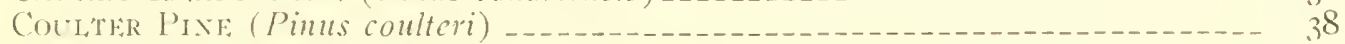

II liPro Pixe (Pinns halepensis) _.

Monterei Pixe: (Pinus radiata)

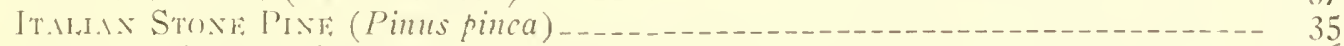

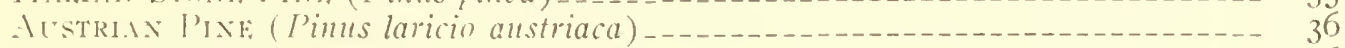

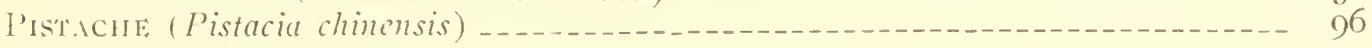

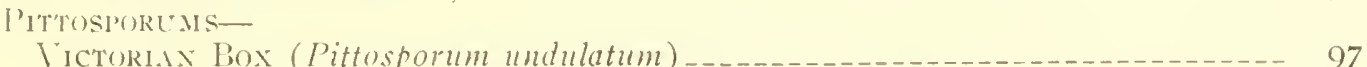

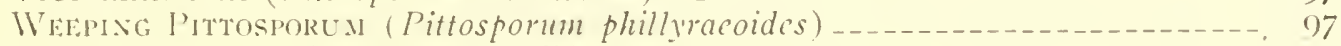

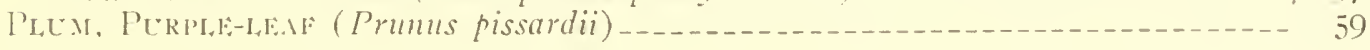




\section{INDEX Continued}

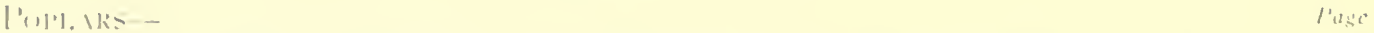

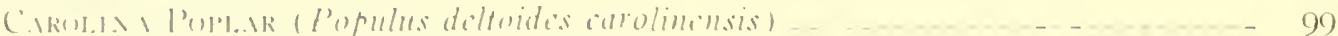

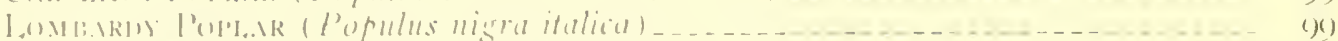

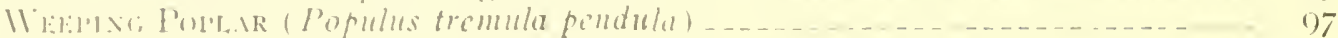

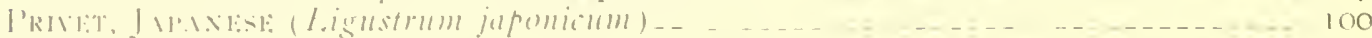

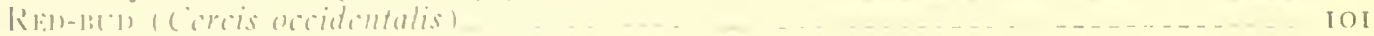

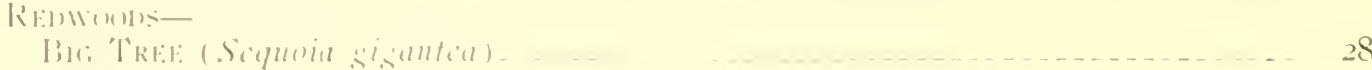

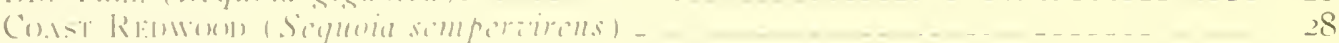

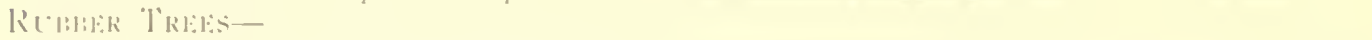

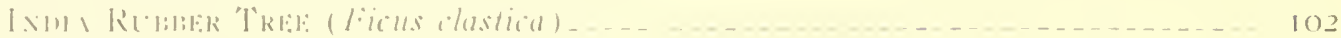

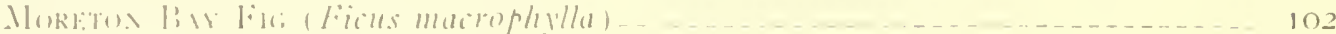

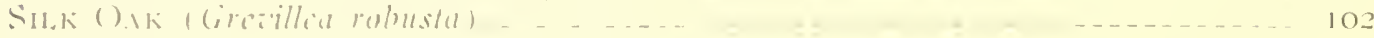

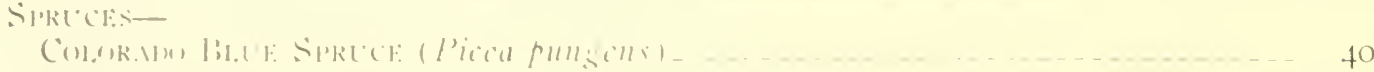

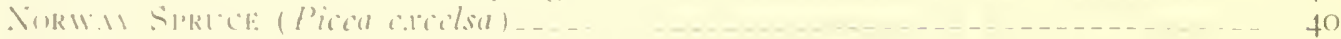

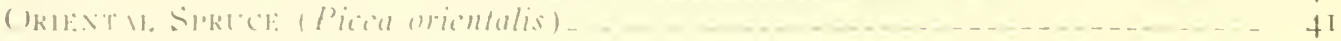

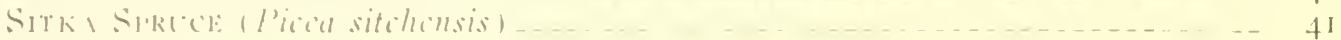

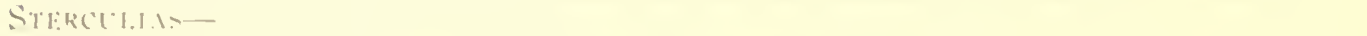

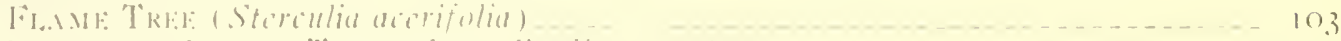

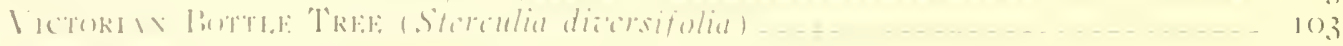

Sisc.1.1161:-

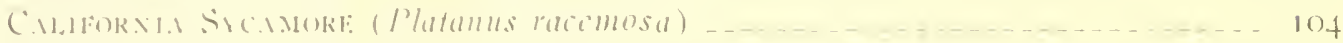

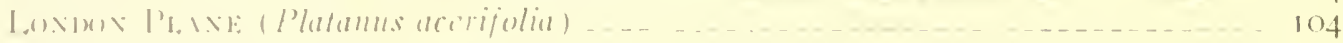

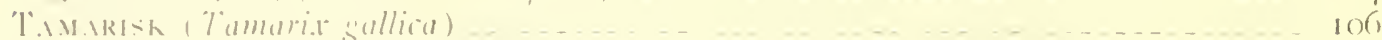

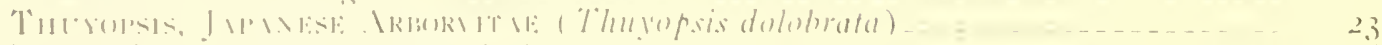

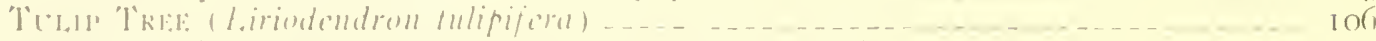

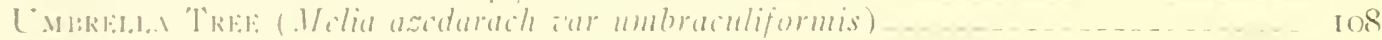

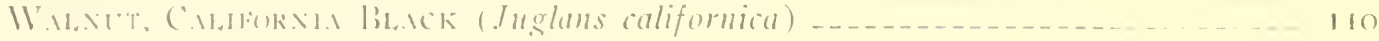

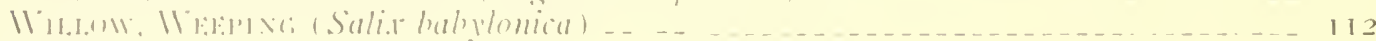

II: $11:-$

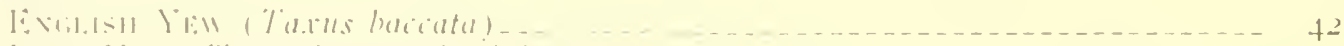

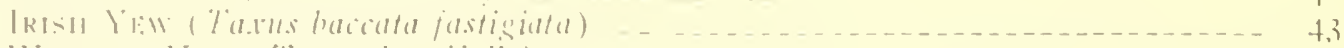

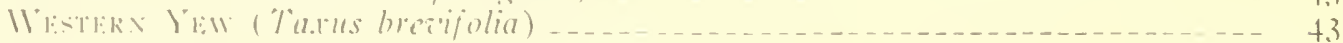

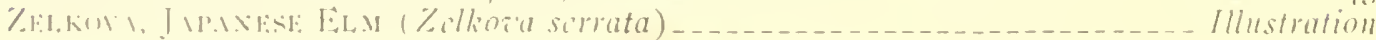

O 


$$
\text { (a) }
$$


$\left(-\frac{1}{1}\right.$

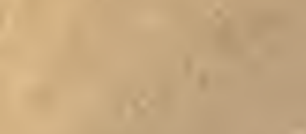

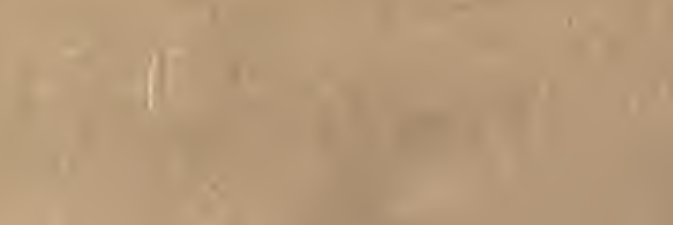

r n n

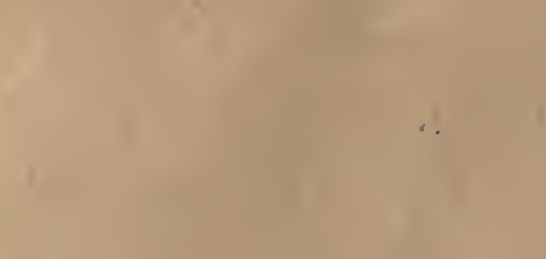

$x$

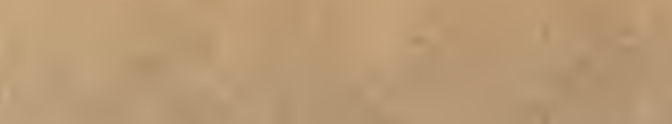

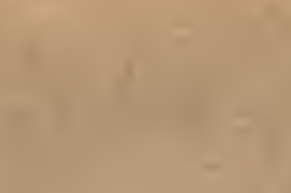

1

t

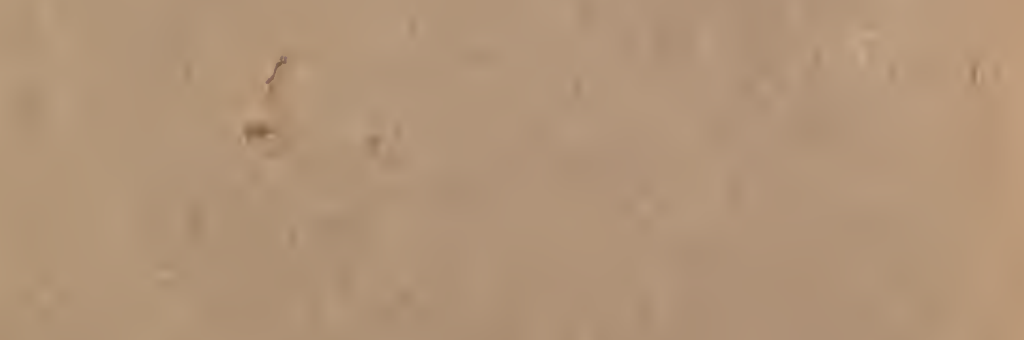

in

4x

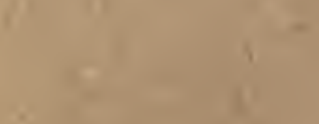

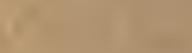

a 1

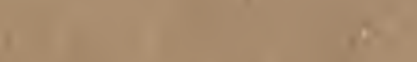

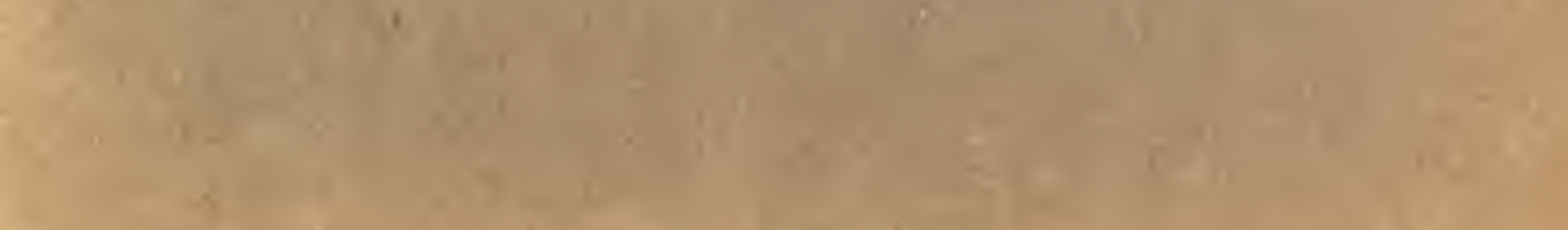

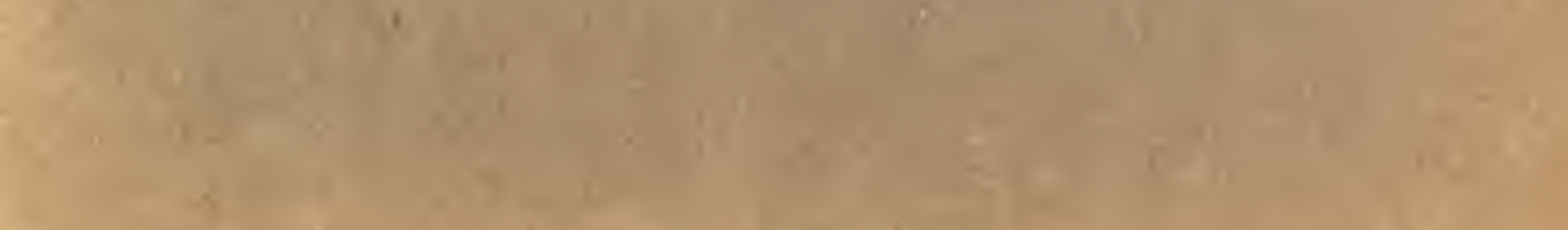

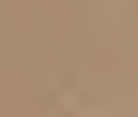

vas

a

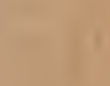




\section{DAY USE}

RETURN TO DESK FROM WHICH BORROWED

\section{LOAN DEPT.}

This book is due on the last date stamped below, or . I on the date to which renewed. Renewgd hooks are subject to immediate recall.

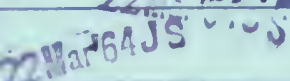

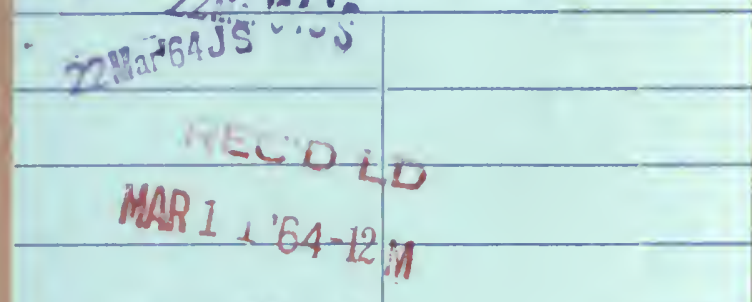

APR $1-1966-5$

HEGOAD

APR 5 'CE-8 AM

NAY 819687 \&

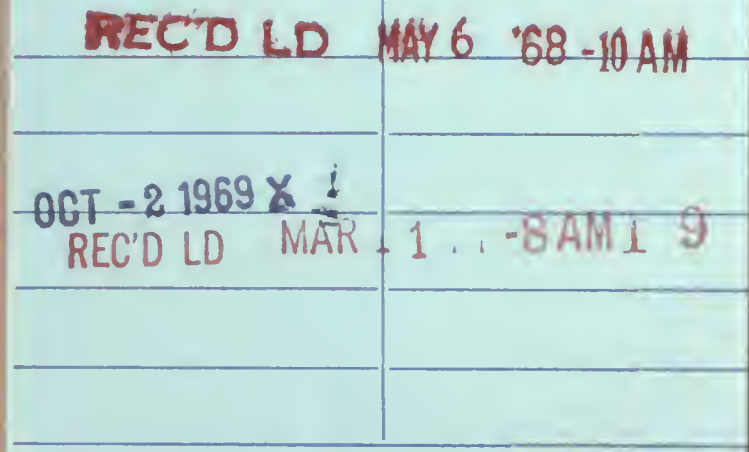




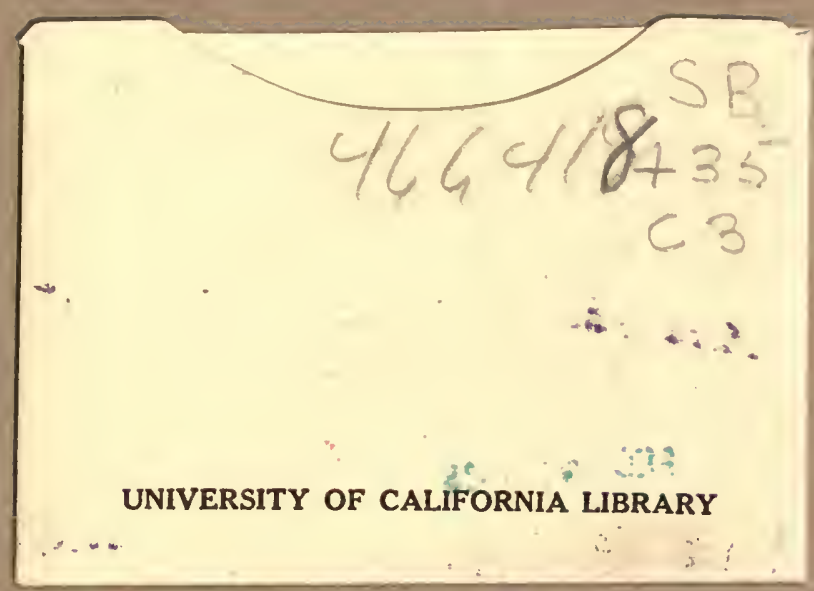

UNIVERSITY OF CALIFORNIA LIBRARY 
